\title{
The Dalradian rocks of the north-east Grampian Highlands of Scotland
}

\author{
D. Stephenson, J.R. Mendum, D.J. Fettes, C.G. Smith, D. Gould, \\ P.W.G. Tanner and R.A. Smith
}

* David Stephenson British Geological Survey, Murchison House, West Mains Road, Edinburgh EH9 3LA.

dst@bgs.ac.uk

$0131650 \quad 0323$

John R. Mendum British Geological Survey, Murchison House, West Mains Road, Edinburgh EH9 3LA.

Douglas J. Fettes British Geological Survey, Murchison House, West Mains Road, Edinburgh EH9 3LA.

C. Graham Smith Border Geo-Science, 1 Caplaw Way, Penicuik, Midlothian EH26 9JE; formerly British Geological Survey, Edinburgh. David Gould formerly British Geological Survey, Edinburgh.

P.W. Geoff Tanner Department of Geographical and Earth Sciences, University of Glasgow, Gregory Building, Lilybank Gardens, Glasgow G12 8QQ.

Richard A. Smith formerly British Geological Survey, Edinburgh.

* Corresponding author

Keywords:

Geological Conservation Review

North-east Grampian Highlands

Dalradian Supergroup

Lithostratigraphy

Structural geology

Metamorphism

\begin{abstract}
The North-east Grampian Highlands, as described here, are bounded to the north-west by the Grampian Group outcrop of the Northern Grampian Highlands and to the south by the Southern Highland Group outcrop in the Highland Border region. The Dalradian succession therefore encompasses the whole of the Appin and Argyll groups, but also includes an extensive outlier of Southern Highland Group strata in the north of the region. The succession includes shallow-marine sequences, glacigenic deposits at two stratigraphical levels, the earliest evidence for volcanism in the Dalradian, a later major development of basaltic and picritic submarine lavas, and thick turbiditic sequences.

In the south, the Grampian-Appin group boundary is a high-strain zone, with no obvious dislocation or stratigraphical excision, which was formerly termed the Boundary slide. Shear-zones at higher structural levels are associated with pre-tectonic granites, such as the Ben Vuirich Granite, which have been dated at C. $600 \mathrm{Ma}$ and hence place limits on the timing of sedimentation, deformation
\end{abstract}


and metamorphism. The region is divided from north to south by a major zone of shearing and dislocation with associated igneous intrusions, termed the Portsoy Lineament. To the west of the lineament, the stratigraphy is more-or-less continuous along strike with that of the Central Grampian Highlands. D1, D2 and D3 structures extend from the Tummel steep Belt north-eastwards throughout this area. The stratigraphical succession is broadly continuous across the Portsoy Lineament but to the east, in the Buchan Block, correlations are more tenuous and do not extend below subgroup level. High-grade migmatitic paragneisses were once interpreted as pre-Dalradian basement but they are now assigned to the Crinan Subgroup, within the Dalradian succession. Within the Buchan block the outcrop pattern is controlled by two broad, open, post-metamorphic folds, the Turriff syncline and the Buchan Anticline.

The Buchan Block is the international type area for the hightemperature/low-pressure Buchan-type regional metamorphism. To the south and west, this passes into higher pressure Barrovian-type metamorphism. South of Deeside, metamorphic conditions reached $820^{\circ} \mathrm{C}$ and over 8 kbar, well into granulite facies and the highest recorded in the Grampian Terrane. The detailed relationship between the high heat-flow and the emplacement of large bodies of basic and silicic magma is a matter of ongoing research. Plutons of the North-east Grampian Basic Suite, emplaced at C. 470 Ma, during or shortly after the peak of metamorphism and the D3 deformation, provide key evidence for the timing of the Grampian orogenic event.

\section{INTRODUCTION}

\section{Stephenson, J.R. Mendum and D.J. Fettes}

The North-east Grampian Highlands are defined here largely by two geological boundaries (Figure 1). To the north-west, the boundary with the Northern Grampian Highlands is taken at the Grampian-Appin group junction, which to the south of the Cairngorm Pluton is marked by the Boundary slide or the Loch Tay Fault; farther north, a rapid stratigraphical transition is present, albeit with some local shearing. To the south, the boundary with the Highland Border region is taken at the top of the Loch Tay Limestone Formation between Pitlochry and the Mount Battock Pluton, and then along the projected continuation of the Argyll-Southern Highland group junction on Deeside, east to Aberdeen. The short southwestern boundary with the Central Grampian Highlands is the valley of the rivers Garry and Tummel, as followed by the railway and $A 9$ road, between Pitlochry and Blair Atholl.

The region is divided into three distinct geological areas by two of the major lineaments of the Grampian Highlands (see Stephenson et al., 2013a). The east-west Deeside Lineament, to the north of the River Dee, is marked by a line of large granitic plutons with only narrow intervening outcrops of Dalradian strata. The Dalradian succession is generally coherent across this essentially late-Caledonian lineament, although some facies changes have been recognized and many of the formation names change. Hence it is a 
useful boundary for descriptive purposes, at least in upper Deeside. The north-south Portsoy-Duchray Hill Lineament is an older structure that was active during Dalradian sedimentation and was a locus for basic magmatism and major tectonic dislocation during the Caledonian Orogeny (Fettes et al., 1986; Goodman, 1994). It forms a fundamental stratigraphical and structural boundary stretching from the north coast at Portsoy to Glen Muick on south Deeside. To the south-west of the Lochnagar Pluton, it is less well defined but marks changes in stratigraphy that were recognized by Barrow (1912). It is coincident with the later, brittle Glen Doll Fault for some distance but turns towards the south-west, along strike, and peters out beyond Duchray Hill in Glen shee.

To the west of the Portsoy-Duchray Hill Lineament, Dalradian successions and structures can be traced into those of the Northern and Central Grampian Highlands with little difficulty. A generally eastward-younging stratigraphical succession does seem to continue, albeit with some attenuation and disruption, across the lineament and elements of the structural history are common to both sides. However, to the east of the lineament only tentative stratigraphical and structural correlations can be made with higher parts of the Dalradian succession elsewhere and this area seems to have had, to some extent, a distinctly different sedimentological, structural and metamorphic history. It is commonly referred to as the 'Buchan Block' and has been regarded by several authors as a tectonically juxtaposed separate subterrane. Regional gravity and magnetic anomalies, which show steep gradients coincident with the Portsoy-Duchray Hill Lineament, suggest that there are fundamental differences in the sub-Dalradian basement (Trewin and Rollin, 2002). The southern margin of the Buchan Block is difficult to define either geologically or geophysically. It extends southwards at least to the Deeside Lineament, where the geophysical anomalies are subsumed by the plethora of large granitic plutons. To the south of Deeside the lithologies and structures gradually merge with those of the Highland Border region.

Early interpretations divided the succession in the Buchan Block into a 'Banff division', restricted to a 'Banff Nappe', separated by a slide from an underlying, more typical Dalradian sequence, termed the 'Keith division' (Read, 1923, 1955; Read and Farquhar, 1956). Although some authors have also suggested that parts of the area are allochthonous (Sturt et al., 1977; Ramsay and Sturt, 1979), most current interpretations have attempted to correlate the stratigraphical succession in broad terms (i.e. at subgroup level) with Argyll and Southern Highland group successions farther to the south-west (Harris and Pitcher, 1975; Ashworth, 1975; Harte, 1979; Treagus and Roberts, 1981; Ashcroft et al., 1984; Fettes et al., 1991; Harris et al., 1994; Stephenson and Gould, 1995).

Several other lineaments and dislocations in the North-east Grampian Highlands have been recognized as being of more than just local significance. Some have contributed significantly to debates over the timing of Caledonian and earlier deformation, and their associated intrusions have provided material for precise radiometric age determinations that now define magmatic events both at $600 \mathrm{Ma}$ and $470 \mathrm{Ma}$. 


\subsection{Stratigraphy}

\subsubsection{Pitlochry-Blair Atholl area to Deeside}

In this area, most of the Appin and Argyll group succession can be correlated precisely with that of the adjoining Central Grampian Highlands, certainly down to formation level and in many cases also down to member level (Figure 2). However, facies changes do occur, most notably the disappearance of the schiehallion Quartzite between Glen Tilt and Glen Shee, partly resulting from structural excision but most probably due to non deposition or a local unconformity. The absence of this familiar marker, together with its basal tillite sequence, does cause problems in that it results in the juxtaposition of the Killiecrankie Schist (Easdale Subgroup) upon the lithologically similar upper part of the Blair Atholl Subgroup. As the Cairn Mairg Quartzite of the Central Grampian Highlands is also absent from this area, correlations of some key units between the lower part of the Blair Atholl subgroup and the distinctive graphitic pelites and calcareous schists in the upper Easdale Subgroup are rather uncertain (Goodman et al., 1997; Crane et al., 2002). This in turn makes it difficult to estimate the magnitude and significance of ductile displacements on some highstrain zones. Local names for stratigraphical units are a particular problem owing to the large number of workers who have worked here at different times, with varying success in attempts to correlate with adjoining areas. Unfortunately, many of these names have been adopted on BGS maps, the publication of which which has spanned a significant time period. Only recently has an attempt been made to rationalize the nomenclature in the BGS Lexicon of named rock units and those names have been used in this special issue wherever possible.

Throughout much of this area the junction of the Appin Group with the underlying Grampian Group is coincident with a zone of high strain that is a continuation of the Boundary Slide-zone from the Central Grampian Highlands. However, at the Gilbert's Bridge GCR site in Glen Tilt there does appear to be a continuous stratigraphical transition from the Struan Flags of the Grampian Group into calcareous semipelite lithologies of the Glen Banvie Formation that have been assigned to the Lochaber Subgroup. A similar situation occurs south-west of Braemar at the Glen Ey Gorge GCR site, where flaggy psammites of the Grampian Group are overlain by highly strained pelites and semipelites of the Tom Anthon Mica Schist Formation (Upton, 1986).

All the constituent formations of the Ballachulish Subgroup can be traced from the Blair Atholl area (Smith and Harris, 1976) north-eastwards to Braemar (Upton, 1986), where they can still be matched almost bed for bed with those in the type areas of Lochaber and Appin. The distinctive basal dolomitic metalimestone, the graphitic pelites passing via a striped transition into the An Socach Quartzite, and the topmost limestone and phyllite formation with its crystalline white limestone and striped 'tiger rock', can all be found throughout this area (Figure 2). 
The base of the Blair Atholl Subgroup is well marked throughout the area by a change from a background lithology dominated by semipelites and psammites to one in which dark schistose pelites predominate. Thick units of dark bluish-grey graphitic metalimestone in the lower part of the subgroup are a distinctive feature and several have been quarried extensively. Higher parts of the subgroup tend to be paler and more semipelitic. Although some of the metalimestones are laterally persistent, some units have been recognized only locally, and it is the broad characteristics of the subgroup that enable it to be traced from Blair Atholl through the Glen Shee area almost to Braemar (Bailey, 1925; Pantin, 1961; Smith and Harris, 1976; Upton, 1986; Goodman et al., 1997; Crane et al., 2002).

The Schiehaliion Quartzite is the only unit of the Islay Subgroup represented in the Blair Atholl area. In the lower part, locally developed conglomeratic beds contain scattered clasts of granite and quartzite and are considered to be equivalent to the tillites of the Schiehallion Boulder Bed; dolomitic beds are also present locally. The quartzite thins considerably north-eastwards and is eventually excised by a slide in Glen Tilt. It re-appears, with basal boulder beds, farther north-east in the Glen shee area, where it is termed the Creag Leacach Quartzite. This passes up through a transition formation of interbedded quartzite and black graphitic pelite into the graphitic Glas Maol Schist Formation, followed by calcareous semipelite and schistose calcsilicate rocks (the Glen Girnock Calcareous Formation), a sequence typical of the upper part of the Easdale Subgroup in the Central Grampian Highlands (i.e. Ben Eagach Schist and Ben Lawers Schist equivalents). At Coire Loch Kander, stratabound syn-sedimentary barium deposits, similar to those at the Craig an Chanaich to Frenich Burn GCR site in the Central Grampian Highlands and at the same stratigraphical level, occur in the Glas Maol Schist Formation. A 15 m-thick band of barian quartzite contains sphalerite, galena and iron sulphides, and bedded baryte-quartz rock, $4.5 \mathrm{~m}$ thick, has been proved by drilling over a strike length of $700 \mathrm{~m}$ (Fortey et al., 1993). The upper part of the Easdale Subgroup is dominated in places by basic meta-igneous rocks. On Ben Vrackie, near Pitlochry, these have been interpreted as intrusions, but in the Ballater area a sequence of banded amphibolites at the top of the Easdale subgroup represents basic lavas in an equivalent position to the tuffaceous Farragon Beds (Goodman and Winchester, 1993; Fettes et al., 2011) (Figure 2).

In the Pitlochry area, the Crinan Subgroup is represented by the dominantly semipelitic Ben Lui Schist Formation, as is the case throughout the Central Grampian Highlands. However, north-eastwards from Ben Vrackie, the metamorphic grade of the Ben Lui schist increases. The unit becomes migmatitic with abundant concordant quartzofeldspathic segregations and thick pegmatite veins and pods. In the Glen shee area and through to the headwaters of Glen Isla and Glen Clova, the Ben Lui Schist Formation (known locally as the Caenlochan Schist) grades into lit-par-lit migmatites that constitute the Duchray Hill Gneiss Member (Williamson, 1935). The equivalent Queen's Hill Formation can be traced north-eastwards into Glen Muick and to the eponymous 
Queen's Hill, near Aboyne (Read, 1927, 1928). The dominant migmatitic semipelites and pelites, well seen at the Balnacraig, Dinnet GCR site, are interbedded with psammites, rare quartzites and thin bands of calcsilicate rock. The formation also includes numerous bands of gneissose amphibolite, implying that it was a preferred horizon for the intrusion of basic sheets, which dominate the Cairn Leuchan to Pannanich Hill GCR site. Similar migmatitic and gneissose lithologies occur in lower Deeside between the Hill of Fare and Mount Battock granites.

The Tayvallich Subgroup is represented by the Loch Tay Limestone Formation, which can be traced from Pitlochry to Glen Doll. Farther to the north-north-east, calcareous semipelites around the head of Glen Mark pass into ribbed calcsilicate rocks and metalimestones of the Water of Tanar Limestone Formation. In middle Deeside, this becomes the Deeside Limestone Formation (Read 1927, 1928), which consists mainly of calcsilicate rocks with calcareous psammite, amphbolite and thin layers of impure metalimestone. These calcareous rocks are overlain by a diverse but dominantly psammitic unit, the Tarfside Psammite Formation, consisting of quartzites, psammites, semipelites and pelites but with locally abundant calcsilicate and amphibolite bands (Harte, 1979). Parts of this unit are gneissose.

\subsubsection{Deeside to the north coast, west of the Portsoy-Duchray Hill Lineament}

To the north of the Cairngorm, Glen Gairn, Ballater and Mount Battock granitic plutons that mark the enigmatic 'Deeside Lineament', many elements of the Appin Group and lower Argyll Group stratigraphy of the Central Grampian Highlands can still be recognized. This is particularly true of the Lochaber and Ballachulish subgroups, in which correlations are possible at formation level. The Blair Atholl, Islay and Easdale subgroups can also be defined with confidence from their overall lithological characteristics. The succession is terminated to the east by the shear-zone that marks the Portsoy Lineament (Fettes et al., 1991). The continuous section along the north coast that forms the western part of the cullen to Troup Head GCR site has been well known since the work of H.H. Read (1923, 1936), but its connection with the established succession of Perthshire was not known until the detailed resurvey of the North-east Grampian Highlands by the British Geological Survey in the 1980s and 1990s.

A poorly defined association of micaceous psammites with thin lenticular quartzite units overlies Grampian Group psammites conformably south of Tomintoul. However, farther north, psammites grade upwards into slaty and calcareous semipelites, which represent a thin development of the Lochaber Subgroup, well seen at the Bridge of Brown GCR site. Close to the contact the psammites and semipelites are commonly flaggy and highly strained, recalling the features seen along the Boundary slide-zone farther to the south-west.

Still farther north, the Lochaber subgroup thickens markedly between Dufftown and the north coast (Read, 1923, 1936; Peacock et al., 1968). Here a thick sequence of flaggy, micaceous psammites 
and semipelites, the Findlater Flag Formation, forms the lower part of the subgroup, whereas the upper part contains calcareous lithologies, recalling the division in the Lochaber type area. The calcareous rocks are lithologically variable but are characterized locally by abundant tremolitic amphibole (Stephenson, 1993). They are dominated by thinly banded grey, cream and pale-green calcareous psammites and semipelites termed the Pitlurg Calcareous Flag Formation, which grades laterally into the cairnfield Calcareous Flag Formation towards the coast. Beds and lenses of metalimestone occur locally in the upper parts of this formation, presaging the limestone development in the Ballachulish Subgroup.

The Ballachulish Subgroup is well developed and can be traced northwards as far as the Keith area. The Mortlach Graphitic Schist Formation is several hundred metres thick in Glen Livet but thins locally to 5 or $6 \mathrm{~m}$. A dark metalimestone, the Dufftown Limestone Member, is commonly present at or near the base of the formation, and other metalimestones occur in the lower part, notably in Glen Rinnes. The formation appears to thicken markedly on the northeast side of the NW-trending Rothes Fault and, although much of this thickening is probably due to fold repetition, the fault could coincide with an earlier synsedimentary structure or lineament (Fettes et al., 1986). At the base of the Corryhabbie Quartzite Formation there is a transitional unit of interlaminated pelite and psammite, which is thick in the south but is reduced to a few metres farther north, where the formation is made up of a lower thick-bedded psammite unit, a clean, cross-bedded quartzite, and an upper psammite unit. The succeeding Ailnack Phyllite and Limestone Formation consists of phyllitic semipelite, with several distinctive thin white metalimestones, calcsilicate beds and one more-persistent banded metalimestone member. The Dufftown Limestone and Mortlach Graphitic Schist are particularly well seen at the Auchindoun Castle GCR site and most of the succeeding units are exposed at the Bridge of Avon GCR site.

Farther to the north-east, marked facies changes, probably associated with NW-trending growth faults, and increased structural complexity, make individual units difficult to trace so that formations become ill defined. The graphitic character of the lower part of the subgroup is locally much reduced and thick, persistent metalimestones are absent. A condensed sequence of metalimestone and graphite-schist is seen around Deskford, but in boreholes on the coast at Sandend Bay over $300 \mathrm{~m}$ of kyanite-rich schistose graphitic pelite has been proved. The pelite is overlain directly by phyllitic semipelite and metalimestone with no intervening quartzite.

The Blair Atholl Subgroup consists mainly of schistose semipelites, which are locally pelitic, graphitic and calcareous. A thick bluish grey metalimestone formation, the Inchrory Limestone, occurs in its central part (see the Bridge of Avon GCR site report) and minor metalimestones occur locally in the lower part. Maximum development of the subgroup occurs in the upper Donside-Braes of Glenlivet area. Farther north, around Edingight, black graphitic pelites with staurolite are interbedded with thin beds of blue-grey metalimestone. From there the metalimestones thicken considerably northwards and become dominant in the Fordyce 
Limestone Formation that constitutes the only part of the subgroup exposed on the coast in the Cullen to Troup Head GCR site.

The lowest units of the Argyll Group can be traced intermittently to the coast. The lower part of the Islay Subgroup consists of two interdigitating and diachronous formations, both of which are represented in the Kymah Burn GCR site. On Donside, semipelites and pelites with thin metalimestones and metadolomites comprise the Nochty Semipelite and Limestone Formation. These lithologies pass laterally northwards and westwards into thinly interbedded, locally graded, psammites, semipelites and minor pelites, which comprise the Ladder Hills Formation. This formation is several kilometres thick in its type area, but is absent or only thinly developed elsewhere. Boulder beds, typically associated with thin metadolomite beds, occur locally towards the top of the Ladder Hills Formation. The best section of these boulder beds is found in the Muckle Fergie Burn GCR site, south of Tomintoul, where a metadolostone unit is succeeded by a 10 m-thick boulder bed containing clasts of dolostone in its lower, calcareous part and of granite above. Minor beds of basic metatuff also occur locally and in the Muckle Fergie Burn basaltic pillow lavas have been recognized a short distance below the boulder beds. In some areas, for example in upper Donside near Corgarff, boulder beds occur within the lower units of the overlying Kymah Quartzite Formation and in the Kymah Burn GCR site thin basic lavas and tuff lenses are found near the base of the quartzite. The quartzite varies considerably in thickness, from only $10 \mathrm{~m}$ over fault-controlled structural highs (e.g. Lecht-Cockbridge) to a more-typical development of 300 to $500 \mathrm{~m}$ in adjacent basins. To the west of Huntly the Islay Subgroup is cut out structurally by the Portsoy Shear-zone. However, north of the River Isla, the Durn Hill Quartzite is confidently assigned to this subgroup on account of loose blocks of metadiamictite (boulder bed) that have been found within the outcrop of the underlying Arnbath Psammite Formation in several locations around Fordyce and Edingight (Spencer and Pitcher, 1968).

A typical Easdale Subgroup sequence crops out from east of the Glen Gairn Pluton to north of Glenbuchat. There, the Kymah Quartzite is overlain by the Culchavie Striped Formation, a thick sequence of striped semipelites and psammites with a distinctive pebbly quartzite. These are succeeded in turn by the Glenbuchat Graphitic Schist Formation, followed by calcareous semipelites and minor psammites with metalimestone and calcsilicate beds that constitute the Badenyon Schist and Limestone Formation. Graphitic pelites and semipelites are also present around the headwaters of the River Don and in the eastern part of the Muckle Fergie Burn GCR site, where they include the Delnadamph Volcanic Member, consisting of basic pillow lavas and volcaniclastic beds.

To the north of these outcrops, the Easdale subgroup is cut out completely by the Portsoy Shear-zone. However, on the coast, in the Cullen to Troup Head GCR site, a thin development of the Durn Hill Quartzite is succeeded eastwards by a sequence of graphitic pelites and semipelites with metalimestone and quartzite in its upper part, which are intruded by gabbroic and ultramafic rocks within the Portsoy Shear-zone. This Easdale Subgroup sequence, 
consisting of the Castle Point Pelite and Portsoy Limestone formations, is highly strained and very much attenuated as it effectively lies within the shear-zone.

\subsubsection{The Buchan Block}

Within and immediately to the east of the Portsoy Shear-zone are a number of formations, which are commonly bounded by ductile shears and are interspersed with mafic and ultramafic intrusive rocks of the 470 Ma North-east Grampians Basic Suite. They are difficult to correlate with any established successions, but their overall lithological character, consisting largely of semipelites and graphitic pelites with gritty psammites and a few minor metalimestones, is typical of the Argyll Group (Fettes et al., 1991). On published maps they are mostly designated as 'Argyll Group, subgroup unassigned', and they probably belong in the Easdale, Crinan and Tayvallich subgroups.

Most notably, in the Cabrach area, a turbiditic sequence of black pelites, semipelites, psammites, pebbly psammites and metavolcanic rocks is termed the Blackwater Formation. The metavolcanic rocks dominate the lower part of the formation, which is well exposed in the Black Water GCR site. They are composed of aphyric, pyroxene-phyric and pillowed tholeitic metabasalts and both massive and autobrecciated metapicrite lavas (MacGregor and Roberts, 1963; Macdonald et al., 2005). Since the formation appears to pass upwards into Southern Highland Group lithologies, the volcanic rocks have been tentatively correlated with the $600 \mathrm{Ma}$ Tayvallich Volcanic Formation of the South-west Grampian Highlands, with which they share some geochemical characteristics such as unusually strong $\mathrm{Fe}$ and Ti enrichment and some evidence for crustal contamination (Fettes et al. 2011).

The higher parts of the Argyll Group form a broad horseshoe outcrop of generally gneissose semipelitic rocks around the Turriff Syncline, from mid-Donside to Fraserburgh and in a narrower zone from Huntly to Portsoy. Within these poorly exposed areas, thick, mixed sequences of semipelite, psammite and pelite show little mappable variation and no consistent detailed stratigraphy has been established. The metamorphic grade is generally high and most of the rocks are gneissose with local migmatization. The gneissose and migmatitic textures clearly transgress primary lithological boundaries but, by analogy with the development of the Queen's Hill and Duchray Hill gneisses to the south, they have been assigned to the Crinan Subgroup (Read, 1955; Harris and Pitcher, 1975; Harris et al., 1994; Stephenson and Gould, 1995). However, some probably belong to the Tayvallich subgroup and it is possible that minor units of the Easdale Subgroup are included in some areas (e.g. near Portsoy). Hornfelsing and partial melting have further complicated relationships close to the major basic intrusions.

In mid-Donside, between the eastern margin of the Morven-Cabrach Intrusion and the Tillyfourie area, lies the Craigievar Formation, which consists mainly of finely interlayered, schistose and gneissose psammites and pelites. Major developments of pelitic gneiss, concordant amphibolite and thin developments of metalimestone and calcsilicate-bearing rock occur locally. East 
and north-east of the Bennachie Granite Pluton, equivalent Crinan/Tayvallich subgroup rocks are known as the Aberdeen Formation (Munro, 1986). The dominant lithologies are less pelitic than those to the west, consisting mainly of psammites and semipelites and characterized by small-scale compositional banding.

The gneisses of the Ellon Formation crop out around the lower Ythan valley (Read, 1952; Munro, 1986). They are derived mainly from semipelitic and psammitic metasedimentary rocks, although amphibolites are abundant locally. Calcsilicate rocks are rare. The gneisses are distinguished from those of the Aberdeen Formation by their lack of regular lithological banding, their poor fissility and a foliated, streaky appearance. Bodies of migmatitic 'granite' are widespread. The boundary with the Aberdeen Formation is transitional in places but elsewhere it is marked by shear-zones. To the north and east of Ellon, the Ellon gneisses grade into the structurally overlying Stuartfield 'division' of semipelites, pelites, psammites and metagreywackes. The upper part of this 'division' has a more coherent stratigraphy and is termed the Strichen Formation. To the north this may be further divided into a lower part containing massive channel quartzites up to $500 \mathrm{~m}$ thick (e.g. the Mormond Hill Quartzite Member) and an upper part containing calcareous beds; the latter have been taken to indicate that the Strichen Formation spans the boundary between the Crinan and Tayvallich subgroups (Kneller, 1988).

To the north of Peterhead is the Inzie Head Gneiss Formation (see Read and Farquhar, 1956). This mixed assemblage of rocks, exposed in the Cairnbulg to St Combs GCR site, has a general migmatitic appearance due to more-homogeneous granitic gneisses alternating with schollen and schlieren gneisses. The schollen show a wide range of metasedimentary lithologies, including calcsilicate rock and psammite, and can be discerned locally in trails resembling dismembered sedimentary units. More-coherent bands of amphibolite, psammite and calcareous schist with impure metacarbonate rock have been mapped in places. On the west side of the Turriff Syncline, the Cowhythe Psammite Formation crops out along the coast east of Portsoy (see the Cullen to Troup Head GCR site report), and extends southwards to near Huntly (Read, 1923). It is composed essentially of schistose psammite and semipelite with rare metalimestone and pelite beds. Streaky lit-par-lit migmatites and feldspathized rocks occur, particularly in the semipelitic units, but for the most part the original compositional banding can still be discerned.

Most of the dominantly gneissose units described above probably include some Tayvallich Subgroup rocks, as indicated by the presence of calcsilicate and metalimestone beds. Notable examples are the calcareous parts of the Strichen Formation and its lateral equivalent, the Kinnairds Head Formation, which is well exposed on the north coast in the Fraserburgh to Rosehearty GCR site. Although metalimestone beds up to $20 \mathrm{~m}$ thick do occur in the Strichen Formation, calcareous units are restricted in general to thin-banded calcsilicate beds in an overall sequence of pelite, semipelite and psammite.

On the west side of the Turriff Syncline, the Tayvallich Subgroup comprises a 1200 m-thick sequence of semipelite, calcsilicate rock 
and metalimestone, termed the Boyne Limestone Formation (Read, 1923; Sutton and Watson, 1955). It includes the Boyne Castle Limestone Member, a thickly bedded but finely banded metalimestone, some $200 \mathrm{~m}$ thick (Figure 2) (see the Cullen to Troup Head GCR site report). The metalimestones can only be traced inland for some $2.5 \mathrm{~km}$ through poorly exposed ground.

The Southern Highland Group occupies the broad core of the Turriff Syncline, represented by the Fraserburgh to Roseharty GCR site and the eastern part of the Cullen to Troup Head GCR site, and a small outlier on the east coast around the Collieston to Whinnyfold GCR site.

In the Turriff Syncline a sedimentological transition from the Argyll Group into the Southern Highland Group is well seen. On its western limb, the base of the Southern Highland Group is drawn in the coast section at the base of the first gritty psammite that marks the change from lagoonal deposition of calcareous silts and muds to turbiditic sedimentation. The overlying succession consists of some $2000 \mathrm{~m}$ of psammite, with subordinate semipelite and pelite, referred to as the Whitehills Grit Formation. On the eastern limb a similiar transition is observed from the calcareous successions of the Kinnairds Head Formation and the Strichen Formation into the non-calcareous psammites and pelitic lithologies of the Rosehearty Formation and Methlick Formation (Read and Farquhar, 1956). In the core of the syncline the Southern Highland Group is represented by the Macduff Formation (1700 m), a finer grained, more-distal turbidite facies with slump deposits, clean channel sandstones and subsidiary greywackes (Sutton and Watson, 1955). A more-persistent semipelitic facies to the south-west has been termed the Clashindarroch Formation, and this unit has been quarried extensively in the past for roofing slate in an E-Wtrending belt to the north of the Insch and Bogancloch intrusions.

The closure of the Turriff Syncline can be traced to the south of the Insch Intrusion, in the Correen Hills. There, the Southern Highland Group is represented entirely by the suie Hill Formation, which consists dominantly of semipelite and gritty psammite with prominent pelite units. The base is taken at a magnetite-bearing schistose pelite, which forms a regional magnetic anomaly. Similar magnetic units occur on the western limb of the syncline and elsewhere in the basal part of the group; the influx of detrital magnetite could indicate a change in provenance caused by the unroofing of a new source or a mafic volcanic input.

On the east coast, low-grade turbiditic rocks occur in an eastward-younging sequence, represented almost in its entirety by the Collieston to Whinnyfold GCR site but traceable for only a few kilometres inland (Read and Farquhar, 1956; Munro, 1986). These rocks, termed the Collieston Formation, are assigned to the Southern Highland Group and form a predominantly psammitic graded sequence with characteristic 'knotted' pelites containing andalusite and cordierite. Contacts with adjoining units are not exposed but south of Collieston lenses and beds of calcsilicate rock are common and thin impure metalimestones also occur, possibly indicating a transition downwards into the Argyll Group.

Boulders and pebbles of igneous and metamorphic rocks, some of extrabasinal origin, occur in the higher exposed part of the 
Macduff Formation in the coastal section at Macduff (see the Cullen to Troup Head GCR site report). These deposits have been interpreted as the products of ice-rafting or as debris flows linked to marine tills (Sutton and Watson, 1954; Hambrey and Waddams, 1981; Stoker et al., 1999). Some poorly preserved microfossils have also been found in the adjacent rocks and correlations with various glacial periods, some as young as Ordovician, have been suggested (see Stephenson et al., 2013a).

\subsection{Structure}

\subsubsection{Major dislocations}

The development of the concept of a 'Boundary Slide' separating the Grampian Group from higher stratigraphical units of the Dalradian throughout much of the Grampian Highlands has been fully discussed by Stephenson et al. (2013a). The Boundary Slide can be traced north-eastwards from Glen Tilt, where it is well exposed in a continuous section at the historic Gilbert's Bridge GCR site, through the Glen Ey Gorge GCR site in upper Deeside to the eastern end of the Cairngorm Granite Pluton (Upton, 1986). However, there its overall effect might be much reduced. Farther north, zones of high strain, accompanied locally by slides, are common at or below the Grampian- Appin group transition, e.g. around Strath Avon, at the Bridge of Brown GCR site, and in the upper part of Glen Rinnes. Between Glen Rinnes and the north coast, at the western end of the Cullen to Troup Head GCR site, the Grampian-Appin group boundary appears to represent a relatively undisturbed, rapid stratigraphical passage.

In this northern part of the region, ductile dislocations occur at both higher and lower stratigraphical levels than the GrampianAppin group boundary, although it is unclear whether any of these relate specifically to the Boundary slide. The zones of shearing in Glen Rinnes can be projected north-eastwards towards a major NEto NNE-trending shear-zone that passes through Keith and can be traced for some $30 \mathrm{~km}$ to reach the coast between sandend and Portsoy in the Cullen to Troup Head GCR site. The effect of this Keith Shear-zone upon the succession is difficult to determine owing to poor exposure and uncertainties about the stratigraphical affinities of some of the units involved but it appears to have excised parts of the Ballachulish Subgroup in places. The shearzone consists of multiple branches, each dipping at a low to moderate angle towards the south-east quadrant and commonly showing a very strong down-dip stretching lineation. Shear-sense indicators suggest a thrust (top to north-west) sense of movement. Between the branches are several pods and lenses of deformed muscovite-biotite granite, and zircons from two separate lenses of this Keith-Portsoy Granite have yielded a precise U-Pb intrusion age of C. $600 \mathrm{Ma}$ (Barreiro, 1998). Although the granite pods and adjacent metasomatic country rocks were deformed and metamorphosed during the Grampian Event, which was undoubtedly a time of major movement on the shear-zone, the sites of the individual shears were clearly a locus for the intrusion of granite sheets. Hence they 
must follow earlier lineaments that were in existence at around 600 Ma, possibly soon after sedimentation as the youngest rocks affected are lower Islay subgroup.

The best known and most extensively studied of the pre-Caledonian c. $600 \mathrm{Ma}$ intrusions is the Ben Vuirich Granite, between Pitlochry and Glen Shee, which has yielded much vital information about the timing of Caledonian deformation and metamorphism. Determinations of the age of the intrusion and interpretations of its structural setting have changed considerably since its significance was first recognized by Bradbury et al. (1976) and these make the Ben Vuirich GCR site one of the most significant in this special issue. The granite was intruded into Blair Atholl subgroup strata at around $590 \mathrm{Ma}$ and hence provides a minimum age for Appin Group deposition (Rogers et al., 1989; Pidgeon and Compston, 1992). It is now considered to have been deformed by the D2 phase of deformation of the Grampian Event (Tanner, 1996). The age and significance of an earlier, D1 fabric affecting the granite is still a matter of debate (e.g. Dempster et al., 2002; Tanner, 1996; Tanner et al., 2006). The intrusion does crop out between major slides to the north-west and south-east, but there is no evidence that these are earlier structures that might have controlled granite emplacement. However, smaller nearby bodies of foliated granite, at Glach Ghlas in Glen Tilt, and near Fealar Lodge, are either located between major slides or within ductile shear-zones.

A number of major zones of shearing and dislocation occur on the western margin of the Buchan Block and each of these has been used at some time to define its limit. Thrust-related fabrics at the western margin of the Cowhythe Psammite Formation were attributed by Elles (1931) to a Portsoy Thrust, which is now regarded as the eastern limit of the 1 km-wide Portsoy Shear-zone, described in detail in the Cullen to Troup Head GCR site report. Earlier fold axes and lineaments have been rotated so that they plunge down-dip adjacent to and within the zone and a down-dip stretching lineation is present locally. Highly sheared mafic and ultramafic igneous rocks occupy the centre of the zone and cross-cutting, but lineated, sheet-like granite bodies are present near the margins. This zone can be traced inland to the south-south-west as a narrower zone of dislocation that forms the western boundaries of the Huntly-Knock and Morven-Cabrach mafic-ultramafic intrusions (Munro and Gallagher, 1984; Ashcroft et al., 1984) and defines the northern part of the Portsoy-Duchray Hill Lineament (Fettes et al., 1986, Goodman 1994). Major stratigraphical and structural discontinuities occur across the shear-zone and marked differences in metamorphic history on opposite sides indicate major westward overthrusting during the regional D3 event (Baker, 1987; Beddoe-Stephens, 1990). The margins of major syn-D3 maficultramafic intrusions of the North-east Grampian Basic Suite are severely affected by this and by other related shear-zones, and their aureoles have been displaced by several kilometres in places, suggesting significant lateral movement (Ashcroft et al., 1984). Kneller and Leslie (1984) demonstrated that the shearing occurred whilst the adjacent rocks were at or close to their peak metamorphic conditions. Farther south, the Coyles of Muick Shearzone, to the west of the Cairn Leuchan to Pannanich Hill GCR site, 
lies on the same lineament, although there the discontinuities are less marked (Goodman, 1994).

On the eastern edge of the Cowhythe Psammite Formation outcrop is another zone of highly deformed rocks with some thin mylonites. This zone marks the position of the Boyne Line of Read (1955), which was interpreted as a major slide underlying his proposed allochthonous Banff Nappe. In Read's model, movement on the Boyne Line was held responsible for the excision of Tayvallich subgroup calcareous lithologies, which are absent over much of the North-east Grampian Highlands, apart from the Boyne Limestone Formation, which is seen only in the coast section.

Some structural and $\mathrm{Rb}-\mathrm{Sr}$ geochronological evidence has been interpreted to infer that the Cowhythe Psammite Formation, along with all the other gneissose units of the North-east Grampian Highlands, represents a pre-Caledonian Neoproterozoic basement gneiss complex (Sturt et al., 1977). Ramsay and sturt (1979) suggested that all the rocks above the Portsoy Thrust constitute an allochthonous block, and that this consists of a gneissose basement separated from a Dalradian metasedimentary cover by a décollement along Read's Boyne Line. However, subsequent detailed mapping and advances in the reliability of radiometric dating techniques now suggest that the gneissose parts of the succession can be explained as part of the Dalradian stratigraphy, albeit heavily deformed, thrust and metamorphosed during the mid Ordovician Grampian Event (see Ashcroft et al., 1984; Stephenson and Gould, 1995).

\subsubsection{Folding}

Between the Tay Nappe and the Boundary Slide there is a progressive change in dips from the flat-lying strata and pervasive s2 cleavage of the Flat Belt, north-westwards into a $10 \mathrm{~km}$-wide zone of steep to vertical folded strata known as the Tummel steep Belt (Bradbury et al., 1979) (Stephenson et al., 2013a, fig. 7). The tight, upright folds characteristic of the steep belt have been documented in the Central Grampian Highlands east of the Loch Tay Fault by Treagus (1999, 2000) and a similar structural pattern can be traced north-eastwards into the Kirkmichael-Glen shee area (Crane et al., 2002) and on towards Braemar, where it is known as the Cairnwell Steep Belt (Upton, 1986). Throughout these areas, the steepening has been interpreted as at least partly the result of late, D3 to D4, ENE-trending flexuring and corrugation of pre-existing flatlying, recumbent, SE-facing D1 and D2 structures linked to the Tay Nappe and its complementary underlying syncline, formerly referred to in this area as the Kirkmichael Fold (Bailey, 1925; Read, 1935, 1955). Tight $F 3$ folds are commonly co-axial with the earlier folds and hence the F1, F2 and F3 fold closures can be difficult to distinguish. In some areas, large-scale F2 and F3 folds trend north-west, most notably in the complex $5 \mathrm{~km}$-wide NW-trending Carn Dallaig Transfer Zone that effectively links the Tummel steep Belt and the offset Cairnwell steep Belt (Crane et al., 2002, fig. 19). This transfer zone has a marked effect upon the outcrop pattern in the Gleann Fearnach area, but as the F2 fold axes are not reorientated within it, Crane et al. interpreted it as a steep 
transpressive D2 structure, analogous to a lateral ramp in thrust terrains.

To the north of the Deeside Lineament and west of the PortsoyDuchray Hill Lineament, Appin and Argyll group rocks are disposed in a series of large-scale NW- to SW-facing early tight folds, which can be traced downwards into the underlying Grampian Group. A related fine-scale penetrative cleavage (S2) is also developed. Later folds, which fold the s2 fabric and post-date the primary metamorphic assemblages, are commonly co-axial with the early folds. The related S3 penetrative cleavage, typically a finely spaced or a tight crenulation, is best developed in the morepelitic lithologies (well seen in the Auchindoun Castle GCR site). These F3 folds are typically close to tight and upright to NWfacing. Their axes trend north or north-east and they exert a strong control on the outcrop pattern both locally and regionally, as is well demonstrated by the Ardonald Fold in the Dufftown area. Post-D3 minor chevron folds and kink bands are widely developed but usually only local in extent. In part they are related to late uplift, faulting and basement block movement.

Within the main part of the Buchan Block, along the north coast that forms the eastern part of the cullen to Troup Head GCR site and the Fraserburgh to Rosehearty GCR site, the rocks of the Macduff Formation exhibit locally complex open to tight upright Fl folding. A related S1 spaced cleavage, formed by pressure solution, is well developed in the psammites and a slaty cleavage occurs in the intervening pelites. The folding, is responsible for the generally steep bedding dips over much of the section, although regionally the dip of the overall stratigraphy is relatively shallow (Figure 3a). In fact, the outcrop pattern is controlled by two late (D3 or D4), open, broad, upright folds, the Turriff Syncline and the Buchan Anticline, whose axes plunge gently to the north-north-east. Read (1955) considered that the Dalradian succession, which is generally the right way up across the section, constitutes the upper limb of a major early SE-facing recumbent anticline which he termed the Banff Nappe (Figure 3b). The overall 'nappe' has similarities to the Tay Nappe of the Highland Border region and some authors have linked the two structures (e.g. Treagus and Roberts, 1981; Ashcroft et al., 1984). In Read's model, the high-grade migmatitic gneisses seen in the Cairnbulg to St Combs GCR site form the core of the nappe and are exposed in the hinge-zone of the later Buchan Anticline (Read and Farquhar, 1956). To the west of Banff the beds are subvertical and form the steep limb of a monoform, regarded as a major early (F1) fold closure by Sutton and Watson (1956) who named it the Boyndie Syncline. Subsequent workers have regarded this structure as a later (F3) structure, devaluing its regional importance (Johnson and Stewart, 1960; Johnson, 1962; Fettes, 1970), although Treagus and Roberts (1981) also assigned it to D1.

Recumbent, tight to isoclinal, east-facing F1 folds occur on the east coast and are well exposed at the Collieston to Whinnyfold GCR site. The fold geometry is in marked contrast to the north coast section, where bedding is generally steep within the shallow Turriff Syncline; here the generally flat-lying beds collectively define steeply dipping overall stratigraphical boundaries (Figure 
40), a point that was highlighted by Read and Farquhar (1956). The beds are regionally inverted and the folds and cleavages face to the east. A major early fold closure must occur between this section and the coast sections around Fraserburgh, where the succession is the right way up. The axial surface of this fold cannot readily be traced; it lies in a poorly exposed complex sheared zone between Ellon and Inverallochy that is characterized by the presence of several mafic intrusions and high-grade metamorphism. It was regarded as the hinge-zone of the Banff Nappe by Read (1955) and Read and Farquhar (1956) and some later workers have regarded it as equivalent, at least in part, to the Tay Nappe (Stephenson et al., 2013a, fig. 7). Such a correlation must however remain highly speculative given the considerable distance between the traces of the structures and the intervention of the Deeside Lineament.

\subsection{Metamorphism}

The North-east Grampian Highlands include an area of Buchan metamorphism, characterized by low $\mathrm{P} / \mathrm{T}$, an area of typical Barrovian intermediate-P/T metamorphism and a transitional zone between the two focussed on the Portsoy-Duchray Hill Lineament. This pattern can be attributed to high heat flow in the Buchan area, falling off to the west and south. In general, the metamorphic grade increases with structural and lithostratigraphical depth, the lowest grade rocks occurring in the core of the Turriff Syncline (Stephenson et al., 2013a, fig. 12). The highest grade rocks are associated with late-metamorphic intrusions (see below). The porphyroblast growth was broadly synchronous across the region and occurred from syn-D2 to syn- to post-D3 (Johnson, 1962, 1963; Crane et al., 2002; Strachan et al., 2002).

In the area west of the Portsoy-Duchray Hill Lineament, metamorphic mineral assemblages are characteristic of the epidoteamphibolite facies in the south but mostly fall within the lower amphibolite facies. Mineral assemblages in pelitic lithologies are typical of Barrovian zones (biotite $\rightarrow$ garnet $\rightarrow$ staurolite $\rightarrow$ kyanite $\rightarrow$ sillimanite). In general, progressive increases in pressure are assumed to have taken place during the main phases of deformation, along a simple curve on a pressure-temperature plot, to reach a metamorphic peak in D3. However, in the Tummel Steep Belt the Barrovian zones are poorly developed and Dempster and Harte (1986) documented a significant post-D3 increase in pressure, with the replacement of chloritoid + biotite by garnet + chlorite, as well as the localized growth of kyanite- and staurolite-bearing assemblages. They ascribed the pressure increase, of c. 2-3 kbar, to rotation and burial of originally flat-lying strata (i.e. in the Flat Belt) associated with the development of the D3 steep belt.

In the north, there is good evidence that the line defining the inversion of regional andalusite to kyanite lay to the west of the Portsoy-Duchray Hill Lineament. In a well-defined zone up to $10 \mathrm{~km}$ wide, immediately to the west of the lineament, original andalusite is overprinted by later kyanite as a result of an increase in pressure due to westward overthrusting during D3 (Chinner and 
Heseltine, 1979; Baker, 1985; Beddoe-Stephens, 1990). Pseudomorphs of kyanite after andalusite are well seen in the Auchindoun Castle GCR site and immediately west of Portsoy in the Cullen to Troup Head GCR site.

To the east of the Portsoy-Duchray Hill Lineament, the metamorphic conditions were characterized by low pressures $(2-4 \mathrm{kbar})$ and by a high temperature gradient. This is the type area for the Buchan zones (biotite $\rightarrow$ cordierite $\rightarrow$ andalusite $\rightarrow$ sillimanite $\rightarrow$ sillimanite+K-feldspar). The lowest grade rocks (greenschist facies) occur at the highest structural levels, in the core of the Turriff Syncline, and the metamorphic grade increases structurally downwards. The regional high geothermal gradients were closely associated with the emplacement of large volumes of basic and silicic magma, during or shortly after the peak of metamorphism at c. $470 \mathrm{Ma}$ (Fettes, 1970; Pankhurst, 1970; Ashworth, 1975, 1976). Consequently the highest grade rocks are found in close contact with these igneous bodies, with local pressures and temperatures of over 8 kbar and C. $820^{\circ} \mathrm{C}$, characteristic of granulite-facies conditions (Baker and Droop, 1983; Baker, 1985). Granulite-facies hornfelses and migmatites, characterized by garnet-orthopyroxenecordierite assemblages, are found in the roof-zones, inner aureoles and in screens within the mafic and ultramafic intrusions, notably the Huntly-Knock Pluton (Fletcher and Rice, 1989). The assemblages imply that anatectic melting occurred at temperatures of $800-900^{\circ} \mathrm{C}$ under pressures of 4.5-5 kbar (Droop and Charnley, 1985; Johnson et al., 2001a; Droop et al., 2003). The link to the large earlyOrdovician granite intrusions is not clear. However, Johnson et al. (2003) showed that granulite-facies metamorphism and emplacement of mafic rocks into the host Dalradian metasedimentary rocks is a feasible mechanism to have derived granitic melts, which might have coalesced to form larger bodies such as the Strichen and Aberdeen plutons (c.f. Oliver et al., 2008). The higher grade rocks have been subjected to widespread migmatization, as is well seen in the Cairn Leuchan to Pannanich Hill, the Balnacraig, Dinnet and the Cairnbulg to St Combs GCR sites.

The background cause of metamorphism across the Grampian Highlands was thermal relaxation of an overthickened crust. In addition, in the North-east Grampian Highlands there was a very significant advective heat input, leading to the low-P/T style of metamorphism (e.g. Vorhies and Ague, 2011). How far the various syn- to latemetamorphic igneous intrusions are the underlying cause of this advective heat and how far they are an expression of it is uncertain.

Initial workers believed that the thermal effects of the igneous bodies were imposed on a regional metamorphic pattern. For example, Chinner (1961, 1966) argued that sillimanite formed in response to a thermal overprint on an original depth-controlled metamorphism. However, Fettes (1970) demonstrated that the 'regional' porphyroblast growth was also directly related to the effects of the igneous bodies. Harte and Hudson (1979) recognized two phases of sillimanite growth, closely linked in time, one 'regional' and the other related to the basic intrusions. On this basis, they delineated a 'regional' sillimanite isograd within the overall sillimanite zone (Stephenson et al., 2013a, fig. 12), 
although they agreed that both phases might relate to a general high heat input. However, in the high-grade areas of the south the distinction is problematical and more-recent work, for example in the area around the Cairn Leuchan to Pannanich Hill GCR site, has regarded the sillimanite growth as the climax of a single prograde event (Smith et al., 2002).

Current models for metamorphism clearly identify the advective heat input (including that from the igneous bodies) as the primary cause of the higher grades of metamorphism. Thus the growth of sillimanite must be seen as the culmanating phase of the progressive metamorphism in the areas of greatest heat input. As such, any separation of growth phases might relate to a pulsed heat input (Ague and Baxter, 2007; Vorhies and Ague, 2011).

The cause of the high heat input and associated magmatism in Buchan is uncertain; it might relate to lithospheric stretching and/or slab drop-off beneath the Buchan area immediately following the main arc-continent collision that resulted in the Grampian orogenic event (Kneller, 1985; Oliver, 2002).

\subsubsection{The North-east Grampian Basic Suite}

The large intrusions of mafic and ultramafic rock are entirely confined to the Buchan Block and comprise the North-east Grampian Basic Suite. They are described in some detail in the Caledonian Igneous Rocks of Great Britain GCR volume (Stephenson et al., 1999) but the relationships between the intrusions, the Buchan metamorphism and the D3 deformation make the suite a vital time marker for the peak of the Grampian Event. A number of $\mathrm{U}-\mathrm{Pb}$ mineral ages are now available from these intrusions, which imply that basic and silicic magmatism was focussed in a short time interval at around $470 \mathrm{Ma}$. It seems clear that the Grampian Event in the North-east Grampian Highlands was well under way by 480-475 $\mathrm{Ma}$ and was completed by c. $460 \mathrm{Ma}$ (Oliver et al., 2000; Oliver 2001; Carty 2001; Dempster et al., 2002).

\section{BEN VUIRICH}

\section{(NO 008 686-NO 012700 AND NN 990 703)}

\section{P.W.G. Tanner}

\subsection{Introduction}

Ben Vuirich $(2903 \mathrm{~m})$ is a prominent feature in the Perthshire landscape, $13 \mathrm{~km}$ north-east of Pitlochry. It provides some excellent exposures of the deformed and foliated Ben Vuirich Granite Intrusion, which was emplaced before the main deformation and regional metamorphism that has affected the Appin Group country rocks. Its importance has therefore long been recognized as a target for radiometric dating to determine a minimum age for the Dalradian succession. More recently, with its radiometric age well established as $590 \mathrm{Ma}$, attention has turned to its field relationships, which reveal crucial evidence for the relative 
timing of structural events that have affected the granite and its host rocks.

The Ben Vuirich Granite is a member of the small, but geologically important, suite of pre-Caledonian intrusions that has commonly been referred to as the 'Older Granites' (e.g. Barrow et al., 1905). Such granites are uncommon but are scattered widely throughout both the Northern Highlands and the Grampian Highlands. Several smaller bodies occur near Ben Vuirich in Glen Tilt (e.g. within the Gilbert's Bridge GCR site). Recent radiometric dating has added several new intrusions to this suite, which is now recognized as representing a major 600 Ma magmatic event (Strachan et al., 2002; Kinny et al., 2003b). Hence any deductions regarding the structural relationships and timing of the Ben Vuirich intrusion have profound implications for the tectonic history of the whole Grampian Terrane.

The Ben Vuirich Granite Intrusion was first described by Barrow et al. (1905) and is included in the British Geological Survey's 1:50 000 Sheet 55E (Pitlochry, 1981). Research into the structural significance and age of the granite has aroused much controversy, which was generated initially by a large difference between the apparent ages given by early Rb-Sr (whole-rock) and U-Pb (zircon) dating methods (Giletti et al., 1961; Bell, 1968; Pankhurst and Pidgeon, 1976), and later by disagreement over structural correlations. A precise U-Pb age on abraded zircons from the Ben Vuirich Granite of $590 \pm 2$ Ma, obtained by Rogers et al. (1989), combined with the existing structural interpretation of Bradbury et al. (1976), was thought to show that the Dalradian block had been affected by both a Neoproterozoic orogeny (D1 and D2) and an Early Palaeozoic orogeny (D3 and D4). The 590 Ma age was subsequently confirmed by Pidgeon and Compston (1992) using the SHRIMP ionmicroprobe. However, the structural interpretation was challenged by Tanner and Leslie (1994) who concluded that:

(1) the foliation in the granite is correlated with s2 in the country rocks, and

(2) the granite is pre-D2 in age and only post-dates a fabric which is possibly of regional D1 age.

The current dispute is between those workers who consider that the intrusion was most likely intruded, during a pre-orogenic rifting episode, into previously undeformed sedimentary rocks at C. $590 \mathrm{Ma}$ (Soper and England, 1994; Tanner, 1996; Soper et al., 1999; Tanner et al., 2006) and those who favour emplacement into a sequence that had already been affected by a pre-590 Ma Neoproterozoic orogenic event (Rogers et al., 1989; Bluck and Dempster, 1997; Dempster et al., 2002). In short, whether or not a pre-Grampian orogenic event has affected that part of the Dalradian supergroup that lies below the base of the Southern Highland Group (dated at C. 600 Ma; Dempster et al., 2002), the origin of the earliest fabric in the hornfels and xenoliths found at this GCR site is pivotal. Two critical localities, one within hornfels of the contact metamorphic aureole and the other featuring xenoliths within the marginal part of the granite, preserve evidence of the undeformed nature of the 
Dalradian host rocks immediately prior to the intrusion of the granite.

\subsection{Description}

The Ben Vuirich Granite Intrusion is a small $(6 \times 2 \mathrm{~km})$ sheet-like body of pink or grey peraluminous monzogranite containing megacrysts of oligoclase and K-feldspar, up to $7 \mathrm{~mm}$ in length, together with quartz, muscovite, biotite, titanite, zircon and almandine-grossular garnet. It cuts poorly exposed metacarbonate rocks, quartzites, psammites, semipelites and pelites belonging to the Blair Atholl Subgroup of the Appin Group (Crane et al., 2002). The Dalradian country rocks have been affected by four phases of deformation (D1-D4), the first three of which comprise the Grampian Event. The granite was variably deformed during D2, resulting in NE-trending zones of strongly foliated rock transecting the main body of weakly foliated to granoblastic granite (Figure 4). The intrusion lies within the Tummel steep Belt and is contained between two tectonic slides (ductile faults) of D2 age (Crane et al., 2002) (Figure 4). The Killiecrankie or Glen Loch Slide is inferred to follow the western margin of the intrusion, where metacarbonate rocks belonging to the Sron nan Dias Pelite and Limestone Formation strike towards this contact, and there is clear excision of part of the stratigraphical sequence. The Creag Uisge slide to the east of the intrusion is seen locally as a prominent zone of mylonitic rock, and its position farther south is taken as the western margin of the Ben Lawers Schist.

The Ben Vuirich GCR site consists of two groups of exposures (localities A and B on Figure 4). An exposure of hornfels found at locality $A$ on the north-west flank of the mountain is the only place in the whole Dalradian outcrop where rocks from the contact metamorphic aureole of one of the 'Older Granites' are exposed. At this locality, spotted hornfels have developed in finely banded semipelite typical of the Tulaichean Schist Formation (Crane et al., 2002, plate 4). At locality $B$ on the north-east side of the body, xenoliths of locally-derived quartzose psammite, caught up in the granite magma before it was fully crystalline, preserve the lithological layering but show no sign of pre-intrusion minor folding. There, the granite locally cuts across bedding in the Tulaichean Schist Formation.

The main feature of the GCR site is the hornfels that occurs in metre-scale exposures and small patches of scree on the north-west side of the hill. The early workers reported hornfels-like rocks (Barrow et al., 1905; Pantin, 1961) but it was not until 1990 that the spotted hornfels was discovered at locality $\mathrm{A}, 750 \mathrm{~m}$ westnorth-west of the summit of Ben Vuirich (Tanner and Leslie, 1994). Examination of the material in the screes shows that the hornfels grades from finely laminated, non-spotted rock to coarser grained, spotted hornfels that originally contained andalusite (of the chiastolite variety) and cordierite. The andalusite-bearing types are inferred to have come from the innermost parts of the aureole. Porphyroblasts of andalusite are now pseudomorphed by feathery intergrowths of kyanite and are identical to those found in the contact metamorphic aureole of the Carn Chuinneag intrusion, an 
'Older Granite' in the Moine Supergroup rocks of Sutherland (Tanner, 1996). The largest and most abundant spots were originally of cordierite; they reached $2 \mathrm{~cm}$ across and grew across a pre-existing, fine-grained fabric. That fabric is still preserved within the pseudomorphs after cordierite, although the original mineral has been altered to an aggregate of minute flakes of biotite and muscovite, with small grains of almandine garnet 0.4-0.8 mm across (Figure 5) and less-obvious kyanite needles.

Petrological studies have shown that the original overall contact metamorphic assemblage, which contained cordierite \pm andalusite, has been overprinted and converted to an equilibrium assemblage of muscovite + biotite + garnet + kyanite + plagioclase + quartz during the D2 regional metamorphism (Tanner and Leslie, 1994; Tanner, 1996). A scanning electron-microscope and electronmicroprobe study of the small regional metamorphic D2 garnets has shown that they preserve an extremely unusual chemical zonation with, for example, Ca increasing from the core to the rim of the garnet (Ahmed-Said and Tanner, 2000).

At locality B, an irregular contact of the granite with quartzite and quartzose psammite is well exposed locally, with apophyses of granite cutting the country rock. Angular to sub-rounded xenoliths of country rock are common locally in the marginal facies of the granite; they commonly preserve a finely spaced alternation of light and dark layers, which on microscope examination is seen to be bedding with some mimetic growth of micas (Tanner and Leslie, 1994; Tanner, 1996; Tanner et al., 2006). Along the contact farther to the south-west, schistose pelites containing garnet over $1 \mathrm{~cm}$ across are in direct contact with the granite.

\subsection{Interpretation}

Now that both the radiometric age for the granite intrusion of 590 $\mathrm{Ma}$, and the D2 structural age of the main fabric that affects it, are generally accepted, the only contentious issue at present concerns the origin of the early fabric in the Ben Vuirich hornfels. It is developed in rocks with a grain size of only 0.1$0.4 \mathrm{~mm}$ and, in all but the highest grade (andalusite-cordierite) hornfels, represents a very low-strain deformation (Figure 6). This fabric could have resulted from:

(1) Neoproterozoic, pre-D1, tectonism;

(2) D1 deformation at an early stage in the development of the Tay Nappe; or

(3) Deformation of the country rocks synchronous with emplacement of the granite.

There are problems with both (1) and (2) above. If the fabric is of Neoproterozoic (pre-590 Ma) age, it would be absent from all rocks younger than the 600 Ma Tayvallich Lavas, and would necessitate the presence of a so-far undiscovered orogenic unconformity within the Argyll Group in Scotland. Alternatively, if the fabric is of D1 age, this would restrict D1 to 600-590 Ma and separate it by $120 \mathrm{Ma}$ from D2 at $470 \mathrm{Ma}$. However, from work at Callander, Tanner (1995) has demonstrated that D1 in Southern 
Highland Group rocks of the Highland Border is post-515 Ma in age (see the Keltie Water GCR site report). As D1 and the D2 can be correlated between the Tummel steep Belt, including the rocks around Ben Vuirich, and the Highland Border (Crane et al., 2002), and an orogenic unconformity has not been demonstrated in this ground, (1) is not a viable option. The most likely interpretation is that the early fabric is of syn-emplacement origin (Tanner, 1996). This conclusion was based on evidence that the pre-hornfels fabric increases in intensity toward the granite margin, and that microveinlets of granite are seen in thin section to have been deformed by the early fabric-forming event.

Further evidence of the nature of the pre-intrusion fabric is given by the xenoliths in the granite at locality $B$. The compositional layering in the population is randomly orientated, with some xenoliths exhibiting folds. However, it is clear that the 52 schistosity in the granite is axial planar to the folds in the xenoliths. In addition, long, thin blocks are parallel with, or at a small angle to, this external s2 fabric, whereas the shorter, more equidimensional, blocks contain folds. This situation is directly analogous to that described from the Port Selma GCR site (Treagus et al., 2013), where a population of clasts originally showing randomly orientated planar bedding, has been deformed. The result is that clasts with bedding initially at a low angle to the resultant cleavage plane are stretched and show boudinaged layers, whereas those with bedding initially at a high angle to the resultant cleavage are buckled internally. The conclusion to be drawn from the Ben Vuirich xenoliths is that the bedding laminations in these were all planar before the D2 deformation, and that the folds seen in some of them are the result of the D2 deformation of the internal foliation of the bedding in suitably orientated xenoliths.

An intriguing feature of the hornfelsed rocks at this GCR site is that they not only preserve a very fine-grained early fabric, but also show little sign of having been affected by the D2 deformation, despite the rocks to either side of them (granite intrusion and country rock, respectively) having been strongly deformed during D2. At that time, the country-rock pelites were being transformed into coarse-grained schists with garnets up to 2 $\mathrm{cm}$ across (see Figure 4 for their distribution). The contact metamorphic assemblage may be used to give an estimate of the lithostatic pressure at which the assemblage crystallized, and hence the depth of emplacement of the granite. Comparison with published data on hornfelsed rocks gave an estimated pressure of 24 kbar, representing a depth of 7-14 km (Tanner, 1996). This conclusion is important when considering the origin and tectonic setting of the granite, and has been the cause of some debate (see Dempster et al., 2002). In addition, the chemical zonation patterns in D2 regional metamorphic garnets reported by Ahmed-Said and Tanner (2000) were interpreted by them to indicate that there was a marked increase in confining pressure as the garnets grew during D2, caused by the major crustal-thickening event that was taking place at the time.

It has been proposed that the granite was emplaced during extensional tectonism approximately synchronous with the eruption 
of the Tayvallich volcanic rocks (e.g. Soper, 1994), and $100 \mathrm{Ma}$ before the Early Palaeozoic Grampian Event. This hypothesis involves neither a separate Neoproterozoic orogenic event, nor a splitting of the D1-D4 deformation episodes in the Grampian Terrane into two packages separated by a long, ill-defined time break. It is supported by the results of a recent geochemical study of the granite (Tanner et al., 2006). The granite samples have a restricted compositional range and occupy the within-plate granite field of Pearce et al. (1984), the A-type granitoid field (on Ga/Al plots) of whalen et al. (1987), and lie wholly within the field for $A_{2}$-group granites, as defined by Eby (1992). Such granitoids are characteristically found in rift-related environments. The Ben Vuirich Granite is one of an increasing number of C. $600 \mathrm{Ma}$ preCaledonian intrusions that are now being recognized throughout the Northern and Grampian highlands of Scotland (Strachan et al., 2002; Kinny et al., 2003b). These are regarded as being related to a swarm of diverse A-type magmatic bodies intruded at around 700-600 Ma which, in a Neoproterozoic reconstruction, can be traced across the Appalachian Fold Belt (Bingen et al., 1998; Tanner et al., 2006).

\subsection{Conclusions}

The Ben Vuirich Granite was one of the first members of an important suite of c. 600-milion-year-old intrusions to be recognized and dated radiometrically. Members of this suite were intruded into the Neoproterozoic rocks of the Scottish Highlands before they were deformed during the Caledonian orogeny. Hence the Ben Vuirich granite is of great national importance. Its radiometric age has been the subject of numerous investigations, initially to establish a minimum age for the Dalradian succession, and increasingly as a means of dating the early phases of Caledonian deformation.

The granite magma was intruded as a sheet-like body into a sequence of limestones, mudrocks, and quartzose sands belonging to the Appin Group. The heat that was released transformed the adjoining sedimentary rocks into a baked rock, or hornfels, of which only a small area remains and is currently exposed at ground level. Because of having been heated to $\mathrm{C} .600^{\circ} \mathrm{C}$, and losing much of their fluid during this process, the hornfelsed rocks became resistant to later deformation and hence much of their early history has been preserved intact. Their most significant feature is that minerals such as cordierite and andalusite, which grew in response to the heat, preserve a weak tectonic fabric within them. Unfortunately, it is not possible to be absolutely certain whether this fabric formed due to the forceful emplacement of the granite, or during an earlier, pre-Caledonian deformation event. However, it is clear that the granite was emplaced before the first deformation to affect the Dalradian Supergroup (D1). Fragments of the country rock that were torn off and encapsulated in the magma when it was emplaced, preserve significant evidence of the nonfolded state of the rocks at that time.

From a study of the mineralogy of the hornfels it has been concluded that the granite stopped rising and had crystallized 
fully at an estimated depth of 7-14 $\mathrm{km}$ beneath the surface of the Earth. The granite and enclosing country rocks were then strongly deformed, metamorphosed, and recrystallized, during the main progressive deformation (D2) and associated climax of regional metamorphism of the Grampian Event at about 470 million years ago. This process had a dramatic effect upon the mineralogy of the hornfels, as the low- to medium- pressure cordierite and andalusite were replaced by new high-pressure minerals such as kyanite and garnet that reflect the greatly increased depth of burial reached during the orogeny.

Geochemical and isotopic analyses of the Ben Vuirich Granite show that it has the chemical fingerprint characteristic of granites found in rifted portions of the Earth's crust. This finding supports an earlier hypothesis that the granite formed in the same extensional tectonic setting that enabled the extrusion of the 600 Ma Tayvallich Lavas to take place (see the West Tayvallich Peninsula GCR site in Tanner et al., 2013a). The granite was possibly derived from partial melting of the Dalradian sedimentary rocks, or their basement, and belongs to a swarm of rift-related granitoids that originally stretched along the Caledonian orogenic belt from the Appalachians to Scotland and heralded the break-up of the supercontinent Rodinia. Hence its age and structural relationships have attracted considerable international interest.

\section{GILBERT'S BRIDGE, GLEN TILT (NN 881 699-NN 903 719)}

\section{R.A. Smith}

\subsection{Introduction}

The river section around Gilbert's Bridge in Glen Tilt, Perthshire is a classic historical GCR site that provides good sections through the tectonized junction between the Grampian and Appin groups of the Dalradian. This junction, between the psammitic Struan Flags to the north-west of Glen Tilt and a pelite, semipelite, metalimestone and quartzite succession to the southeast, was formerly considered to be the Moine-Dalradian boundary. It is currently regarded as part of the Boundary Slide-zone, but its nature is a matter of considerable debate (see 1.2.1 in Introduction).

The first geological appraisal of Glen Tilt was made during the historic visit by James Hutton and Sir John Clerk of Eldin in 1785 in search of evidence for the intrusive nature of granite (see the Forest Lodge GCR site report in the Caledonian Igneous rocks of Great Britain GCR volume; Stephenson et al., 1999). A plan of the central part of the glen, drawn by Clerk, clearly shows the orientation of the strata and three concordant sills of 'porphyry' immediately downstream from Gilbert's Bridge (Craig et al., 1978).

The results of the primary geological survey were published as 1" Sheet 55 (Blair Atholl, 1902) with an accompanying memoir (Barrow et al., 1905). Barrow's interpretation (Barrow, 1904, figure 9) emphasized the importance of concertina folding and metamorphic 
recrystallization of part of the Dalradian to form the 'Moine gneiss'. But it was Bailey (1925) who established that this is the site of a major junction between a very thick succession of struan Flags and the structurally overlying Dalradian. He described the Dalradian succession, which is separated from the bulk of the Dalradian to the south-east by the Loch Tay Fault, as the 'Blair Atholl Series of the Banvie Burn Belt'. He indicated a possible slide between the Banvie Burn Belt and the Struan Flags on his map but was unable to confirm its existence due to lack of local evidence'. Its continuation in the Schiehallion area was later established as the Boundary Slide by Bailey and McCallien (1937), who described a fundamental structure, or decollement, separating complex folding in the Dalradian from simpler structures in the Struan Flags below. Pantin (1961), who introduced the simpler term Glen Banvie 'Series' for the 'Blair Atholl Series of the Banvie Burn Belt', found no evidence for sliding at Gilbert's Bridge. However, Harris (1963) interpreted the junction to be a thrust slide carrying the Dalradian rocks to the north-west, and Thomas (1965, 1980) concluded that the Boundary slide is associated with a tectonic schist equivalent to the Beoil Schist of the Schiehallion area (Rast, 1958) (see the Strath Fionan GCR site report in Treagus et al., 2013).

The Struan Flags have since been re-allocated to the Grampian Group and the Glen Banvie 'series' to the Appin Group, both of the Dalradian Supergroup (Harris et al., 1978). Although the junction is recognized as a zone of high strain (Smith, 1980), the amount of excision could be relatively small because a through succession from the Grampian Group into the Appin Group can be demonstrated nearby in the area around Schiehallion (Treagus and King, 1978; Treagus, 1999). The fact that the Ballachulish Subgroup is present on the southern side of Glen Tilt (Smith and Harris, 1976) also makes the tectonic break less important stratigraphically and the Glen Banvie 'Series' was correlated tentatively with the Lochaber Subgroup by Smith (1980). It has now been formally designated the Glen Banvie Formation.

\subsection{Description}

The section in Glen Tilt between Gilbert's Bridge and Marble Lodge shows a clear and consistent relationship between the struan Flags, now part of the Glen Spean Subgroup of the Grampian Group, and the younger Dalradian (Figure 7). The Grampian Group psammites, which are perfectly exposed in the along-strike river section, have a characteristic parallel flaggy banding which is largely tectonic; their junction with rocks of the overlying Glen Banvie Formation is strongly attenuated. Most of the attenuation appears to be flattening, although a weak down-dip lineation is evident locally and the axial planes of early (F2) folds have been drawn into parallelism with the main foliation.

Sections across the Boundary Slide are exposed in the River Tilt immediately below Gilbert's Bridge (NN 8812 7005), at the junction of the Tilt with the Allt Fas-charaidh (NN 8832 7035), near its junction with the Allt Mhairc (NN 8902 7118) and at Coille Sron an Duine (NN 8950 7164). At all of these localities, approaching the 
Boundary Slide from the Grampian Group, the flagginess of the psammites increases and the banding in them becomes closer spaced and parallel. Coarse white mica is concentrated on the flaggy surfaces. At the slide itself, about $1 \mathrm{~m}$ of coarse muscovitebiotite schist has a platy aspect with parallel quartz lenticles. However, similar bands of schist occur within the Glen Banvie Formation above, together with mylonitized metalimestones and strongly deformed quartzites, so that the formation as a whole appears to constitute a high-strain zone. The strong fabric in the rocks near the slide is best appreciated where small quartz pebbles with elongation ratios of $6: 1$ occur in the quartzites. The elongation lineation is fairly uniform, plunging at about $30^{\circ}$ to the south-east.

On the south-east side of Glen Tilt, the Glen Banvie Formation comprises intercalated metalimestones, calcsilicate rocks, schistose pelites and semipelites, psammites and quartzites. A strong foliation has effectively destroyed any sedimentary structures. Alumina-rich calcsilicate rocks with pink microcline are particularly characteristic of the lower part of the formation. Epidote, actinolite and diopside are present locally in these rocks; plagioclase is less common, as is quartz. Downstream from Gilbert's Bridge at NN 881 698, pale-grey crystalline metalimestones are interbedded with quartz-plagioclase-mica schists. The grey metalimestones contain sparse graphite dust and impure types have tremolite and clinozoisite-epidote or zoisite. Some of the very fine-grained metacarbonate bands are mylonitic. Elsewhere, white metalimestones, up to $2 \mathrm{~m}$ thick, are fairly common and several contain calcsilicate minerals. A well-known example of the latter type is the 'Glen Tilt Marble', which was quarried for a short time at NN 9027 7186. This decorative marble has pale and darker green blotches of serpentine mineral (antigorite) elongated within the foliation. Antigorite is a common alteration product of tremolite, diopside and forsterite. White mica (?talc) lies in the foliation but pyrite is disseminated within the marble. Dolomitic metalimestones are also present and are composed of up to $90 \%$ fibrous tremolite.

In the central part of the Glen Banvie Formation, a quartzite unit, up to $300 \mathrm{~m}$ thick, forms a persistent marker (Figure 7). Within the quartzite are local feldspathic bands and thin beds of dark pyritic semipelite. Above and below the quartzite are pelites composed of quartz-muscovite-biotite-plagioclase, with or without garnet and kyanite. Some of the pelites are intercalated with fine-grained quartzites on a centimetre scale; others are graphitic and many are retrogressed to chloritic schists. Slightly calcareous pelites contain zoisite, clinozoisite and minor calcite. Near the Sron a' Chro Granite, andalusite porphyoblasts overprint the earlier pelitic assemblages.

The Glen Banvie Formation contains two types of amphibolite that are both considered to have been intrusions; thin sheets of darkgreen hornblende schist and larger amphibolitic bodies. The hornblende schists contain up to 75\% hornblende, minor plagioclase, quartz, garnet, titanite and iron oxides; the larger bodies additionally contain thin leucocratic bands rich in pinkish sericitized plagioclase, quartz and epidote. 
Two sheets of foliated granite are exposed in Glen Tilt about $30 \mathrm{~m}$ above the Boundary Slide. They are up to $2 \mathrm{~m}$ thick and are roughly concordant with the foliation/banding in the Glen Banvie Formation. The reddish biotite granites show a granoblastic texture of quartz, microcline and albite, and a parallel alignment of sparse biotite laths. Minor secondary muscovite is present and biotite is locally retrogressed to chlorite. At NN 895716 by the River Tilt, xenoliths of biotite semipelite (0.15 to $1.2 \mathrm{~m}$ long) possess a foliation that is oblique to the one in the granite.

The Glen Banvie Formation has been subjected to three major phases of deformation (Smith, 1980). It typically has a strong flaggy foliation dipping at about $40^{\circ}$ to the south-east, which is a composite S1+S2 fabric. Boudinage of the more-competent bands within the main foliation is common and is accompanied by flexing in the less-competent units. Most of the long axes of boudins trend north-east perpendicular to a stretching lineation and both are considered to relate to D2. It is likely that the foliation of the granite sheets is also related to D2, so that the oblique fabric preserved in the xenoliths is probably S1 (c.f. Bradbury et al., 1976; Tanner and Leslie, 1994; Tanner, 1996). A poorly developed local crenulation cleavage is assigned to D3. Local brittle deformation, fracturing and kink bands are related to sinistral movement on the Loch Tay Fault, a branch of which lies about $0.5 \mathrm{~km}$ south-east of Gilbert's Bridge (Treagus, 1991).

The peak regional metamorphism is of amphibolite facies, as is indicated by the presence of kyanite-grade assemblages in the pelites. Estimates of pressure and temperature on garnet rims from the Glen Tilt area indicate 9-12 kbar and 550-620 $\mathrm{C}$ (Wells and Richardson, 1979). Recrystallization of minerals such as the amphiboles in the hornblende schists (post D2) and later partial retrogression of the rocks is common.

\subsection{Interpretation}

There are two issues concerning the geology of the central section of Glen Tilt that have generated much debate in the past and are not as yet fully resolved. The first is the stratigraphical affinity of the Glen Banvie Formation and the second is the nature and regional significance of the high-strain zone, the so-called Boundary slide, that lies between this and the structurally underlying 'Struan Flags'.

The varied lithological assemblage that comprises the Glen Banvie Formation, with its distinctive calcsilicate and metacarbonate rocks, resembles parts of the Appin Group. However, it is difficult to correlate with the Dalradian succession because it lies between the Boundary Slide and the Loch Tay Fault. A calcsilicate-bearing metalimestone, about $3 \mathrm{~m}$ thick, downstream from Gilbert's Bridge was formerly correlated with the unit now known as the 'Dark Limestone' of the Blair Atholl Subgroup (Barrow, 1904). Further metalimestone intercalations were considered by Barrow to be folded repetitions of this metalimestone, and in places it was seen to be in contact with the Struan Flags and other rock types such as dark schist and red microcline-rich rock. This was explained as a tightly folded local unconformity of the metalimestone on the Moine 
rocks (Barrow, 1904). However, Bailey (1925) measured the section downstream from Gilbert's Bridge and concluded that the intercalations are not the Struan Flags or the 'Dark Limestone', but are all part of his 'Blair Atholl series of the Banvie Burn Belt'. He suggested that the rocks of the Banvie Burn Belt could be equated with his 'Pale Group', i.e. the upper part of what is now the Blair Atholl Subgroup, but he was not certain because of the structural complexity in Glen Tilt. Pantin (1961) made a similar correlation, although the presence of local graphitic bands and a thick quartzite unit are not consistent with this interpretation. A suggestion by Thomas (1965) that the central quartzite unit occupies a synclinal core, and hence a higher stratigraphical level, was refuted by Smith (1980), who found no structural or stratigraphical evidence for this hypothesis.

Although the outcrop of the Glen Banvie Formation is entirely bounded by faults, its position between the Grampian Group psammites and the upper part of the Appin Group, together with its overall lithology, suggests that it could be part of the Lochaber Subgroup (Smith, 1980) e.g. equivalent to the calcareous upper parts of the Leven schist. It could alternatively represent the Lochaber Subgroup and the lower part of the Ballachulish subgroup in a condensed sequence (c.f. Treagus, 1999, 2000 in the Schiehallion area).

The importance of the Boundary Slide was stressed by Thomas (1980), who interpreted the presence of a muscovite-rich schist to be a result of the sliding (c.f. the Beoil schist of the Schiehallion area). According to Thomas, the slide probably developed during the evolution of the primary Fl nappes but was reactivated locally during later deformation. He described it as a dislocation between the Appin Group succession of the Tay Nappe and the Grampian Group rocks beneath, which form a primary southeast- and downward-facing Atholl Nappe. However, Smith (1980) inferred that, because tight to isoclinal F2 folds had their limbs cut out and were sheared locally along their axial planes during D2, the age of the major sliding is D2. The Glen Banvie Formation as a whole is strongly deformed and there are numerous minor slides between the contrasting lithologies, such as the one that Barrow (1904) interpreted as an unconformity. This fact, coupled with the sharp contrast in stratigraphy between the formation and the Dalradian succession to the south-east, led Smith (1980) to the conclusion that the Loch Tay Fault might obscure another major slide forming the south-eastern boundary to the Glen Banvie Formation. He also suggested that the Grampian Group psammites acted as a competent block during deformation and might have influenced the location of the Loch Tay Fault close to the Boundary Slide.

On a regional scale, the age, nature and importance of the Boundary Slide are still debatable issues. Within the northern Grampian Highlands, Appin Group rocks rest on various levels of the Grampian Group (Smith et al., 1999, Highton et al., 1999), and in the Central Grampian Highlands, large parts of the Appin and Argyll group succession are absent where high-strain zones are present just above the Grampian Group (Roberts and Treagus, 1979). So it is even possible that the Boundary slide and/or related structures 
could conceal orogenic unconformities at various stratigraphical levels, which could eventually help to explain such outstanding problems as the apparently wide age span between older parts of the Grampian Group at c. 730 Ma and the top of the Dalradian, which contains an Early Cambrian (c. 515 Ma) fauna (e.g. Prave, 1999; Dempster et al., 2002; Hutton and Alsop, 2004). See Stephenson et al., 2013a for further discussion.

\subsection{Conclusions}

The River Tilt at Gilbert's Bridge provides a classic section through the junction between the Grampian Group and the Appin Group successions of the Dalradian Supergroup. This junction, usually referred to here as the Boundary slide, was originally regarded as a major tectonic dislocation or decollement between the highly variable lithologies of the Dalradian to the south-east and the structurally underlying, dominantly psammitic succession to the north-west that was formerly regarded as part of the Moine. Subsequent work has failed to find specific evidence for a major dislocation or for significant excision of strata. However, the junction does occur within highly deformed rocks and the Boundary Slide, at least in this area, is presently interpreted as a highstrain zone related to the D2 phase of deformation.

The problem is compounded in Glen Tilt by uncertainty over the stratigraphical affinities of the strata that lie structurally above the Boundary Slide but separated from the main Dalradian succession to the south-east by the Loch Tay Fault. These lithologically variable strata, termed the Glen Banvie Formation and including some distinctive metacarbonate and calcsilicate rocks, are currently assigned tentatively to part of the Lochaber Subgroup. If this correlation is correct, there could be no significant stratigraphical break here at the Boundary Slide between the Grampian Group and the lower part of the Appin Group.

No matter whether the Boundary slide is a major dislocation or merely a high-strain zone focused upon the junction between two successions of markedly different competence, it does constitute a major boundary throughout much of the Grampian Highlands. The section at Gilbert's Bridge is one of the best exposed and the conclusions drawn from this GCR site, however tentative, have broader implications for the possible presence or absence of tectonic and/or stratigraphical breaks elsewhere in the Dalradian succession. It is therefore of national importance.

\section{GLEN EY GORGE (NO $0867 \quad 8834-$ NO $0884 \quad 8630$ )}

\section{C.G. Smith and D. Stephenson}

\subsection{Introduction}

Glen Ey in upper Deeside provides one of the best-exposed sections through the Boundary Slide, a zone of highly strained rocks, which separates the Grampian Group from other, more lithologically 
variable, parts of the Dalradian throughout much of the Grampian Highlands. At one time the slide was regarded as a fundamental tectonostratigraphical boundary separating the Moine and Dalradian successions, but the re-assignation of most of the Moine south-east of the Great Glen Fault to the Dalradian has lessened its potential importance. Discussion now centres upon whether or not the highstrain zone coincides with a major dislocation and whether any stratigraphical units or major structures have been excised (see 1.2.1 in Introduction). The Glen Ey gorge section is particularly valuable since, unlike some sections to the south-west, there is continuity from the top of the Grampian Group, through increasingly strained rocks, into highly deformed schistose rocks assigned to the Lochaber Subgroup at the base of the Appin Group. Here, at least, there would appear to be no reason to suggest that large parts of the succession are missing.

The area around Glen Ey was first mapped by the Geological Survey in 1898-99 and the results were incorporated into the one-inch Sheet 65 (Balmoral, 1904) and the accompanying memoir (Barrow and Cunningham Craig, 1912). This area of the present BGS 1:50 000 Sheet 65W (Braemar, 1989), is for the most part based on the mapping and re-interpretation of Upton (1983, 1986), who was the first to recognize the Boundary slide in the Braemar area. Much of the ensuing geological description and interpretation is based on Upton's work.

\subsection{Description}

The Ey Burn is a major tributary on the south side of the River Dee, approximately $7 \mathrm{~km}$ south-west of Braemar. To the north of the ruins of Auchelie (NO 0875 8630), as far as the bridge at NO 0867 8834, the burn flows for about $2 \mathrm{~km}$ through a narrow gorge, generally less than $10 \mathrm{~m}$ deep but with steep to vertical sides. The best-known part of the gorge, between NO 08728718 and NO 0875 8695, includes a historical curiosity known as the Colonel's Bed. This rocky recess in the western wall of the gorge is where John Farquharson of Inverey, the 'Black Colonel', reputedly hid while being pursued after the Battle of Killiecrankie in 1689.

The Boundary slide in the Ey Gorge separates essentially arenaceous rocks of the Grampian Group from the more-varied pelitic and calcareous lithologies of the Lochaber and Ballachulish subgroups of the Appin Group (Figure 8) .

The northernmost $600 \mathrm{~m}$ or so of the section are entirely within Grampian Group rocks, which dip consistently at low angles (less than $20^{\circ}$ ) to the south-east or east. These uppermost units of the Grampian Group are probably equivalent to the Struan Flags of the Blair Atholl area (see the Gilbert's Bridge GCR site report). In Glen Ey they have been termed the Deeside Quartzites and Psammites by Upton (1983, 1986). These comprise units of pale slabby quartzite and quartzose psammite, 5-15 cm thick, interbedded with pale-green and buff colour-banded psammite and thin beds of semipelite (up to $5 \mathrm{~cm}$ thick). The semipelites contain poikiloblastic garnet aligned parallel to the schistosity, indicating syn- to late-D2 growth. Heavy-mineral laminae are commonly seen in the quartzites and Upton (1983) recorded south- 
easterly younging evidence in the psammites, confirming that the succession is the right way up.

The quartzite and psammite contain bedding-parallel pelitic laminae dominated by thick felts of porphyroblastic muscovite and titaniferous biotite, which define the S2 fabric and whose spacing reflects proximity to the Boundary Slide. Thus, by the bridge at the lowest point in the section, these partings are widely spaced with an interval of 20-30 cm, whereas at NO 08808800 , where a small tributary enters from the east, the spacing reduces from $10-$ $20 \mathrm{~cm}$ at river level to $3-7 \mathrm{~cm}$ at the lip of the gorge. Approximately $20 \mathrm{~m}$ upstream on the east bank, at NO 08798797 , psammite becomes increasingly flaggy upwards and is overlain by quartz schist, marking a transition into the Tom Anthon Mica Schist Formation, the lowest unit of the Appin Group. South of this, the contact between the two formations descends gradually to reach river level at NO 08858776 .

Roughly $200 \mathrm{~m}$ to the south, the gorge turns to the west and the rocks dip gently to the east or, more rarely, to the north-east. As a result of this slight change in overall strike, the gorge cuts down the succession upstream and Grampian Group rocks crop out to form an elongate 'window' up to $100 \mathrm{~m}$ wide and $500 \mathrm{~m}$ long. As in the lower part of the gorge, the quartzites and psammites demonstrate an upward increase in flagginess and pass up into the Tom Anthon Mica Schist Formation at stream level just to south of the Colonel's Bed.

The Tom Anthon Mica Schist, which in this area is estimated to be 40-70 m thick, is a very distinctive platy silvery grey rock. It is essentially a quartz-feldspar-muscovite-biotite schist dominated by thick porphyroblastic muscovite felts, which give the rock its particularly distinctive appearance. Isolated garnets crystallized late, during the D2 deformation. The thick mica foliae are compressed around augens of recrystallized porphyroblastic plagioclase, the lamellar twinning of which has been accentuated by the high strain. Also present are augen-shaped lenses of calcite and calcsilicate-rich hornblendic amphibolites. The lithology at the base of the formation is dominated by mica foliae with only rare lenses of quartz, feldspar and amphibolite. The mica foliae contain heavy minerals such as tourmaline, zircon, apatite and rare small poikiloblastic garnets. There is an upward increase in the quartz-feldspar content of the matrix and at the top of the formation the mica felts are separated by quartzofeldspathic microlithons. This partly reflects a more-arenaceous protolith and partly the effects of high D2 strain producing a pressure-solution striping in the rock.

The top of the Tom Anthon Mica Schist is not exposed in the gorge, but small exposures of epidote-tremolite-dolomite-bearing calcsilicate rock occur in an eastern tributary at around NO 0900 8782 and mark the location of the overlying Baddoch Burn Dolomite. These rocks are easily recognizable and form an important marker horizon. Here they consist of green calcsilicate rocks, dominated by tremolite laths with subordinate amounts of quartz, feldspar and muscovite or phlogopite. The tremolite laths are preferentially aligned, forming a rough schistosity. 
The succeeding Glen Clunie Graphitic Schist Formation crops out in the gorge section to the south of the major NE-trending Tom Anthon Fault (see below). This formation is dominated by dark-grey graphitic pelite with porphyroblasts of garnet, staurolite and kyanite. It is evident from these rocks that garnet and staurolite formed early during D2, whereas kyanite porphyroblasts, which marked growth at the peak of metamorphism, developed statically after D2 but before D4. The formation also includes minor beds of calcsilicate rock and rare psammite units and is cut by hornblendic sheets thought to represent metamorphosed basic intrusions.

close to the Tom Anthon Fault, the dip of the foliation in the Tom Anthon Mica Schist steepens and is predominantly to the north. At around NO 087 869, the Ey Burn swings sharply to the north-east and for about $80 \mathrm{~m}$ follows the trace of the fault, which is well seen in this section. The Tom Anthon Mica Schist is exposed on the north bank of the burn, whereas to the south there are good exposures of intensely tectonized and strongly folded pale-green and grey calcsilicate rocks. The two contrasting lithologies are separated by a breccia zone, over $2 \mathrm{~m}$ wide, of pale-green rock cut by anastomosing calcite veins. A further $30 \mathrm{~m}$ or so to the south another breccia zone separates the calcsilicate rocks from the Glen Clunie Graphitic Schist, which crops out upstream for a further kilometre.

\subsection{Interpretation}

In common with Dalradian rocks elsewhere, at least three of the regional episodes of deformation (D1, D2 and D4) have been recognized in the rocks of the Glen Ey area. They were also affected by two major dislocations of contrasting style and age, the ductile Boundary Slide, which is equated with D2 and the later, more-brittle Tom Anthon Fault. The main fabric/schistosity is recognized as being S2, although evidence of an earlier, S1 fabric is present locally. There is little evidence of early folds in the section, but from the regional synthesis of Upton (1986; Figure 9) it can be established that the rocks all lie on the lower, inverted limb of a major $\mathrm{Fl}$ isoclinal anticline, possibly equivalent to the Tay Nappe, or on a parasitic fold on the lower limb of the nappe. The present disposition and attitude of the rocks is largely attributable to D2, when a stack of tight recumbent downward- and SE-facing folds was created. These F2 folds are broadly equivalent to the Ben Lui folds below the Tay Nappe in the South-west Grampian Highlands. Thus the right-way-up Grampian Group rocks of Glen Ey lie on the upper limb of a major F2 synformal anticline that faces downwards to the south-east. The rocks overlying the Boundary Slide are also right way up, being on the lower limb of the F2 Morrone Antiform, which also faces downwards to the south-east. Only minor, near upright $\mathrm{F} 4$ folds occur in this area.

The nature of the Boundary Slide at this GCR site is ambiguous. There is a well-exposed, gradual, possibly sedimentary, transition from the Deeside Quartzites and Psammites of the Grampian Group into the Tom Anthon Mica Schist of the Lochaber Subgroup, implying little or no dislocation or excision of strata. However, elsewhere in upper Deeside, Upton (1983) has recognized a higher unit of the 
Grampian Group, the Linn of Dee Banded Pelites and Psammites, which is absent from this section. Has it been excised due to truncation of the upper limb of the F2 fold by the Boundary Slide or is it absent as a result of facies changes or an unconformity? Above the inferred position of the slide, the Tom Anthon Mica Schist appears to be analogous to the Beoil Schist of the Schiehallion area (see the Strath Fionan GCR site report in Treagus et al., 2013). These highly schistose lithologies are thought to have developed as a result of high strain on pelitic rocks in the area of the Boundary slide. As is the case elsewhere along its trace, there is undoubtedly high strain focussed upon the marked contrast in lithology and competence at the Grampian-Appin group boundary, but it is not possible to prove any dislocation or excision.

The Tom Anthon Fault is a major dislocation, trending north-eastsouth-west, which can be traced for over $15 \mathrm{~km}$ from Braemar on Deeside to Fealar Lodge in the upper Glen Tilt area. It might be considered as one of several splays of the Loch Tay Fault, which to the north-east of upper Glen Tilt departs from its usual single straight course. The fault plane is considered to be near vertical, as its straight trace is unaffected by considerable topography throughout the area. The movement on the fault is hard to estimate, but it almost certainly includes both strike-slip and dip-slip components. However, the evidence regarding the sense of movement in the Glen Ey area is conflicting. The stratigraphy suggests a downthrow to the south-east. However, Upton (1983) proposed that the rocks to the south-east of the Tom Anthon Fault are at a lower structural level, below the Morrone Antiform. There, the dips of the S2 fabric are much steeper, and the outcrop thickness of the Glen Clunie Graphitic Schist is increased significantly as a result of repetition about the F2 An Socach Fold trace and an F1 fold-pair. This structural interpretation would imply a downthrow to the north-west on the Tom Anthon Fault.

\subsection{Conclusions}

The Glen Ey Gorge encompasses one of the most complete sections through the Boundary Slide, in terms of degree of exposure, accessibility and continuity of Dalradian lithostratigraphy. The perceived importance of the slide has diminished in recent years, as it no longer represents a fundamental tectonostratigraphical boundary between the Moine and Dalradian successions. However, it does comprise a zone of intense ductile deformation that, throughout much of its length, is focussed upon the boundary between arenaceous rocks of the Grampian Group and the more-varied lithologies found in higher parts of the Dalradian succession.

In Glen Ey there is a continuous section, in a right-way-up sequence, from increasingly flaggy quartzites and psammites of the Grampian Group, into the highly sheared Tom Anthon Mica Schist Formation of the Lochaber Subgroup (Appin Group). Large-scale, isoclinal $\mathrm{F} 2$ folds have been identified in the area, and the main deformation fabric is $\mathrm{S2}$, but it is not possible to establish whether any stratigraphical units or any fold limbs have been excised by movement on the shear-zone. The so-called 'slide' could merely be a zone of high strain with no significant displacement. 
A later NE-trending brittle fault, possibly related to the Loch Tay Fault, is well exposed in the gorge and is marked by breccia zones cut by calcite veins.

\section{CAIRN LEUCHAN}

\section{(NO $380 \quad 908-$ NO 393 941)}

\section{C.G. Smith}

\subsection{Introduction}

The hill of Cairn Leuchan $(679 \mathrm{~m})$ is located $5 \mathrm{~km}$ south-east of Ballater in upper Deeside, on the broad NE-trending ridge that separates Glen Muick to the west from Glen Tanar to the east. The GCR site is representative of a variety of rocks that have contributed considerably to the understanding of conditions of high-grade regional metamorphism in the Grampian Terrane. Firstly it lies within the area where Barrow established the concept of metamorphic zones and index minerals. Secondly, it lies close to the trace of the kyanite-andalusite isograd, which in simple terms has been taken to define the boundary between the Barrovian and Buchan styles of metamorphism. Thirdly, and perhaps most importantly, geothermometric and geobarometric studies on gneisses from Cairn Leuchan have established that peak metamorphic temperatures and pressures were among the highest recorded in the Grampian Terrane, and that this was one of the few areas in the Scottish Highlands where metamorphic conditions during the Caledonian Orogeny approached granulite facies.

The primary survey of the Glen Muick-Glen Tanar area was carried out by Barrow in 1896 and the results were incorporated into the one-inch sheet 65 (Balmoral, 1904) and the accompanying memoir (Barrow and Cunningham Craig, 1912). The area lies close to the boundary between the Dalradian of Perthshire and that of the Northeast Grampian Highlands and, as such, forms an important link between these two contrasting successions, as was highlighted by Read (1928). Cairn Leuchan was the focus of detailed studies of metamorphic conditions by Baker and Droop (1983) and Baker (1985). The area was resurveyed by staff of Aberdeen University and Queen's University, Belfast under contract to the British Geological Survey, resulting in a new edition of the 1:50 000 sheet 65E (Ballater, 1995) and an accompanying memoir (Smith et al., 2002).

Bedrock at the GCR site consists dominantly of the Queen's Hill Formation, which in this area constitutes the entire thickness of the Crinan Subgroup and comprises two main gneissose lithologies, one semipelitic to pelitic and one hornblendic. The hornblendic rocks are metamorphosed basic sheets, which were mostly intruded before deformation, although some fine-grained rocks exposed near the base of the formation are regarded as metavolcanic.

The Dalradian rocks were affected by four phases of folding as a result of which the strata are inverted and dip steeply to the north-west. At the same time the rocks underwent high-grade metamorphism and were extensively migmatized. They were intruded subsequently by small late-tectonic ultrabasic to intermediate 
bodies and, to the north and east of Cairn Leuchan and Pannanich Hill, by post-tectonic silicic rocks of the Ballater and Mount Battock granite plutons. Later faults trend north, north-west and east-north-east.

\subsection{Description}

The following account is based on descriptions by Baker and Droop (1983), Goodman et al. (1990) and Smith et al. (2002). Exposures in the immediate area of Cairn Leuchan are dominated by gneissose basic meta-igneous rock with subordinate interlayered metasedimentary gneiss (Figure 10). The meta-igneous rocks show a wide range of magnetic susceptibilities, but generally record higher values than the surrounding metasedimentary rocks, and hence ground magnetic surveys were employed extensively in the last resurvey of the area.

The intrusive meta-igneous rock is part of a sheet-like unit that can be traced along strike for nearly $12 \mathrm{~km}$. To the south of Am Mullach (NO 375 904) the outcrop width of this sheet is generally less than $200 \mathrm{~m}$ but in the vicinity of Cairn Leuchan, largely as the result of repetition in the core of a major F2 fold, it reaches a width of around $1 \mathrm{~km}$. In common with other meta-igneous sheets in the area it consists of coarse-grained hornblendic gneiss, which is locally agmatitic.

Semipelitic to pelitic metasedimentary gneisses are exposed c. 400 $m$ to the north-west of Cairn Leuchan and are inferred from magnetic mapping to underlie the unexposed ground at a comparable distance to the south-east. The outcrop width of these units ranges from nearly $500 \mathrm{~m}$ to less than $30 \mathrm{~m}$.

Three episodes of folding, corresponding to the D1-D3 regional events have been recognized in the Dalradian rocks of the Cairn Leuchan to Pannanich Hill area. In common with the surrounding ground there is no evidence of any large-scale F1 folds. However, the earliest event produced a number of small-scale $(5-10 \mathrm{~cm}$ wavelength or less) rootless isoclines that are intrafolial to the regional fabric and are particularly evident in the hinge-zones of F2 folds. These early structures fold an evenly spaced fabric marked by quartzofeldspathic material, reminiscent of tectonic striping or spaced cleavage. This suggests that these are not truly F1 folds, but could be an early D2 phase. The main deformation occurred during D2 with the development of large asymmetrical folds, and the axial surface trace of a major synform passes directly through Cairn Leuchan. These F2 folds have long NW-dipping and short horizontal or SSE-dipping limbs and plunge to the south-west. It has been suggested that they verge to the north-west, but the outcrop pattern suggests that they verge to the south-east. The main regional fabric (S2) is aligned parallel to the long limbs and hence, in common with the sheet dip, strikes north-east-south-west and is inclined steeply to the north-west. Few examples of $F 3$ folds are to be seen in the area, but the orientation of the $\mathrm{S} 2$ fabric is largely attributed to that phase of folding.

The Dalradian rocks are all coarse-grained gneisses or migmatites, whose mineral assemblages and textures largely reflect the peak 
metamorphic conditions that prevailed during the D2 deformation. The meta-igneous rocks vary from those with a planar gneissose foliation to heavily agmatized types. The latter are characterized by lenticular clots rich in ferromagnesian minerals, surrounded by anastomosing stringers of leucocratic material that can form up to $40 \%$ of the rock; the subparallel alignment of these clots gives rise to an indistinct foliation. Compositional banding is not present. They have the mineral assemblage garnet-clinopyroxenehornblende-plagioclase-quartz-ilmenite-apatite-titanite, although there is considerable variation in the proportions of minerals present; e.g. hornblende content can range from 10-70\%. Garnets are common, particularly in the more-mafic examples, and are of almandine composition, typically $\mathrm{Alm}_{56} \mathrm{Gr}_{30} \mathrm{Py}_{7} \mathrm{Sp}_{7}$, little zoned, and stable within the metamorphic assemblage. In the Cairn LeuchanDrum Cholzie area, diopside occurs as large idioblastic porphyroblasts, several centimetres in diameter, with a typical composition of $\mathrm{Ca}_{1} \mathrm{Mg}_{0.5} \mathrm{Fe}_{0.5} \mathrm{Si}_{2} \mathrm{O}_{6}$. They too are stable within the regional metamorphic assemblage.

The metasedimentry gneisses also exhibit a wide range of mineral assemblages. Simplest are those that consist of quartz, andesine, K-feldspar and dark brown biotite, with accessory opaques, apatite, zircon and titanite. The foliation in the rocks is defined by the orientation of biotite laths and by elongation of quartz grains, which commonly show considerable strain. Almandine garnets are common in pelitic rocks, often being full of biotite and quartz inclusions. They typically have the composition $\mathrm{Alm}_{73} \mathrm{P}_{16} \mathrm{Gr}_{7} \mathrm{Sp}_{3}$, although they can show some zoning, the rims being slightly more Fe rich and Mg poor than the cores. In places the garnets have atoll shapes, the central parts having been replaced by a fine-grained biotite symplectite. Sillimanite is present in pelites as fibrolite, and is also found at the centre of atoll garnets; the sillimanite sworls seen in some specimens could be pseudomorphs after garnet.

Two main episodes of migmitization in the metasedimentary rocks are recognized in the Ballater district; an early generation, which is widely developed and is characterized by stromatic leucosomes of leucotonalitic composition, and a later episode from which the ultimate product is a massive coarse-grained rock of igneous aspect, consisting of biotite, oligoclase and quartz. The later episode has a much more localized development than the earlier. Although it has not been recognized in the immediate area of Cairn Leuchan, there is an extensive development 2-3 km to the north, where it is known as the Pannanich Hill Complex (Goodman, 1991). (See also the Balnacraig GCR site report.)

\subsection{Interpretation}

Major- and trace-element analyses of the basic meta-igneous rocks show they have tholeiitic affinities, typical of the volcanic rocks that were erupted during the extensional tectonic regime that prevailed during deposition of the Argyll and Southern Highland groups (Fettes et al., 2011). It has been suggested that such meta-igneous rocks, which occur throughout the Crinan and Tayvallich subgroups in various parts of the Grampian Highlands, 
were high-level intrusions associated with the volcanic activity. However, those in the area of Craig Leuchan and Pannanich Hill intruded rocks that post-date the nearest metavolcanic rocks (the Meall Dubh Metabasite Formation and the Balnacraig Metabasite Member, close to the Easdale-Crinan subgroup boundary). Hence they were most likely to have been associated with the tuffaceous Green Beds that occur within the Southern Highland Group and crop out extensively in the Glen Clova area, some $15-20 \mathrm{~km}$ to the south (Smith et al., 2002).

The coexisting mineral phases present in the rocks of the Cairn Leuchan to Pannanich Hill area are considered to represent equilibrium assemblages and, other than some minor patchy retrograde alteration, these are the products of peak metamorphic conditions. The assemblage garnet-clinopyroxene-hornblende in the basic meta-igneous rocks suggests conditions that approach granulite facies, although Smith et al. (2002) have suggested that the presence of diopside might reflect the protolith composition rather than metamorphic grade. But, using the garnet-clinopyroxene (Ganguly, 1979; Ellis and Green, 1979) and garnet-biotite (Ferry and Spear, 1978) Fe-Mg exchange thermometers, Baker and Droop (1983) calculated peak pressure in the area to have been close to 8 kbar at $820^{\circ} \mathrm{C}$. Baker (1985) subsequently suggested that pressures might even have exceeded 9 kbar, and these are undoubtedly the most extreme metamorphic conditions so far recognized in the Grampian Terrane.

The mineral assemblages, including abundant sillimanite in the regional foliation, are intimately associated with F2 folds, and hence the peak of metamorphism and the early migmitization were syn-D2. Although there is some evidence in the area (e.g. near Creag Dearg, NO 360 876) that some of the sillimanite developed from kyanite, this is considered to be a continuous prograde regional event and there is no evidence of it being a separate later overprint as was suggested by Chinner (1961, 1966). In rocks of the nearby Pannanich Hill Complex, reaction rims between peak metamorphic assemblages preserved in inclusions of refractory material and the migmatized matrix indicate that the later migmatites developed some time after peak temperatures, almost certainly between D2 and D3 (Goodman, 1991). Formation of these later migmatites was aided by the presence of aqueous fluids, shearing and high heat flow, the latter attributed by Goodman to intrusions of the 470 Ma North-east Grampian Basic Suite that crop out nearby (e.g. the Coyles of Muick Intrusion). There are no estimates of the pressures and temperatures under which the later migmatization occurred, but the minerals present in the Pannanich Hill Complex inclusions, particularly andalusite and sillimanite, indicate that their re-equilibriation occurred at lower pressure than the regional maximum, though possibly still at high temperature, suggesting some post-D2 uplift.

\subsection{Conclusions}

Mineral assemblages in both metasedimentary and basic meta-igneous gneisses of Cairn Leuchan, Pannanich Hill and adjacent areas clearly demonstrate that the peak metamorphic conditions here were 
the most extreme so far recorded in the Scottish Dalradian, with pressures in excess of 8 kbar and temperatures approaching $820^{\circ} \mathrm{C}$. The metasedimentary rocks, together with those of the nearby Pannanich Hill Complex, clearly show two generations of migmatites, the first coinciding with D2 deformation and peak metamorphism, the second occurring somewhat later, after some regional uplift and probably between the D2 and D3 events. The rocks also demonstrate that the growth of sillimanite was the climax of a single prograde metamorphic event and does not represent a later overprint as has been previously suggested. The metamorphic rocks of this GCR site therefore provide a wealth of information on the nature and timing of high-grade regional metamorphism in the Grampian Terrane.

\section{BALNACRAIG, DINNET (NJ $4755 \quad 0045-N J 4855$ 0160)}

\section{Gould}

\subsection{Introduction}

The Balnacraig GCR site in northern Deeside provides a spectacular illustration of the effects of intrusion of basic magma into metasedimentary rocks that were already undergoing amphibolitefacies regional metamorphism. Here, xenolithic gneisses containing large, prismatic crystals of sillimanite have yielded valuable information on the variation of pressure and temperature with time during metamorphism. Adjacent exposures of amphibolite display polyphase folding and are intruded by veins of leucotonalite.

Pelitic, semipelitic and psammitic metasedimentary rocks, belonging to the Queen's Hill Formation of the Crinan Subgroup, were intruded shortly after deposition by sills of tholeiitic dolerite, which are now amphibolite sheets. During the Grampian Event (c. $470 \mathrm{Ma}$ ), amphibolite-facies metamorphism and migmatization occurred, and at the time of peak metamorphism, norites of the Tarland Intrusion were emplaced, resulting in partial melting of the adjacent metasedimentary rocks.

The first geological description of the area followed primary mapping by the Geological Survey (Grant Wilson and Hinxman, 1890). Work by Read (1927) highlighted the evidence for migmatization and 'injection' phenomena, as well as the presence of xenoliths of more-refractory lithologies in the gneissose pelites. Read's detailed petrography still forms the main descriptive work on the rocks, although the interpretation has changed. Read described the rocks between the outcrop of the Deeside Limestone Formation to the south and the gabbroic and granitic intrusions to the north as a 'injection complex', which he considered to be caused by the intimate admixture of silicic igneous materials with sedimentary and igneous materials of earlier date. Depending on the proportion of igneous material, the result ranged from largely metasedimentary 'oligoclase-porphyroblast-schist' through 'oligoclase-biotitegneiss' to 'orthoclase-oligoclase-biotite-gneiss', which Read classed as largely igneous in origin. However, even the latter 
contains fine-grained wisps of quartz, feldspar and biotite, and isolated xenoliths, representing an original metasedimentary host.

Subsequently, Baker (1985) undertook a detailed petrological study, including geothermometry and geobarometry, on these and other selected rocks within the Dalradian of the North-east Grampian Highlands to try to unravel the timing and localization of metamorphic peaks. Then, following a resurvey of the area, Gould (1997) re-interpreted the textural features described by Read as being caused by anatexis. He also recognized the Tarland Intrusion as a syn-D3 pluton of the North-east Grampian Basic Suite, and identified the heat of the basic magma as the cause of the intense local metamorphism and partial melting of the country rocks.

\subsection{Description}

This GCR site is located on the northern side of the valley of the River Dee in Aberdeenshire, about $2 \mathrm{~km}$ north of Dinnet, and is centred upon the cottage at Balnacraig. It lies within a belt of coarse-grained, gneissose metasedimentary rock, $0.3-1.3 \mathrm{~km}$ wide (Figure 11), which includes the rocky hills of Creag Ferrar, Mullloch, Craigie and Scar Hill $(300 \mathrm{~m})$, and extends as far west as the contact with the Tarland Intrusion at NJ 475 015. In places the rocks are recognizably psammitic, semipelitic or pelitic, but in most places the protolith is not recognizable. From south of Craigie to Mulloch, the rocks have suffered shearing and retrogressive metamorphism. However, a traverse from the eastern side of Craigie at NJ 477008 to the summit of Scar Hill (NJ 482 013) enables the full range of partial melting phenomena to be examined and forms the nucleus of the site.

On the eastern slopes of Craigie there is a transition from coarse-grained pelite with scattered porphyroblasts of oligoclase up to $20 \mathrm{~mm}$ across, to gneisses in which pelitic material is cut by irregular veins of granitic material carrying large garnet and biotite crystals. In thin section, the pelites consist of plagioclase $\left(\mathrm{An}_{23}\right)$, biotite, garnet, sillimanite, and magnetite. Minor cordierite and orthoclase are also present. The sillimanite is coarsely crystalline, forming stumpy prisms aligned within the main foliation. Later retrogressive metamorphism has formed sericitic aggregates and, in places, andalusite replaces sillimanite and plagioclase.

The gneisses display a single, coarsely developed foliation, striking north-east and dipping steeply to the north-west. As the traverse is continued from Craigie to Scar Hill, the proportion of granitic material increases and the leucosome of the gneiss includes orthoclase as well as plagioclase feldspar. The feldspar porphyroblasts are mostly well crystallized, and contain few inclusions. The proportion of pelitic material decreases until all that is left is a number of large xenoliths, in which the foliation is no longer parallel to that in the host, and a few streaks of biotite and fibrolitic sillimanite.

The most noteworthy feature of the rocks is the presence of sporadic xenoliths within the porphyroblastic gneisses of morerefractory lithologies (quartzite, calcsilicate rock, silica-poor 
pelitic hornfels) (Read, 1927). These xenoliths vary in shape from elongated to almost spherical (Figure 12).

The siliceous xenoliths are banded feldspathic quartzites with sutured quartz grains. They contain small grains of basic plagioclase and flakes of colourless to red-brown biotite. The pelitic xenoliths contain fractured crystals of garnet and prismatic sillimanite and streaks of biotite lying within aggregates of sericite. Biotite and garnet are in many cases altered to chlorite. One pelitic xenolith contains staurolite, forming large prisms concentrated within certain layers and streaked out into films of pale mica with fibrolite needles. The intervening layers consist largely of large flakes of muscovite and biotite.

Xenoliths of calcsilicate rock show a poikiloblastic granular texture and consist of diopside, amphibole, labradorite plagioclase and quartz. Amphibole-rich xenoliths are abundant; compared with the orthoamphibolites in the intrusive sheets of Craig Dhu and Balnacraig cottage (see below), they contain a higher proportion of amphibole, and the plagioclase is more calcic, reaching anorthite in some cases. Quartz occurs only as small pellets or tubules in the plagioclase and amphibole. Some specimens contain large sievelike porphyroblasts of garnet.

A sheet of amphibolite, about $100 \mathrm{~m}$ thick, is well exposed at Balnacraig Cottage (NJ 479 006). The rocks of the sheet have a grain size of $0.5-1 \mathrm{~mm}$, with a well-developed planar fabric and consist of prismatic hornblende and granoblastic labradorite, with minor clinopyroxene in places. The sheet is traversed by veins of leucocratic material, both parallel to and cutting across the foliation of the amphibolite. The veins consist of plagioclase (generally oligoclase, in contrast to the labradorite of the amphibolite), with minor quartz and hornblende. In places the veins expand into large, diffuse patches within the amphibolite (Figure 13).

\subsection{Interpretation}

Modern interpretations of the xenolithic gneisses at this GCR site, and of other examples nearby within Crinan Subgroup semipelitic rocks, suggest that the least-refractory metasedimentary rocks have been partially melted during the peak of regional metamorphism (syn-D3). This was contemporaneous with the intrusion of magmas, now represented by mafic and ultramafic rocks of the Tarland, Coyles of Muick and other plutons, which produced a large heat flux. A granitic melt was formed first in semipelitic rocks, then in pelites and feldspathic psammites. As the proportion of partial melt of the pelitic rocks increased, to include some ferromagnesian material, the resulting melt crystallized as quartz, orthoclase and andesine, with minor garnet and biotite. The residue after this more-intense partial melting was highly aluminous, and recrystallized as knots of biotite, sillimanite, cordierite, magnetite and, locally, spinel. Later metamorphism, producing andalusite and sericitic aggregates, was post D3, but pre-dated the local contact metamorphism associated with the Mount Battock and Cromar granite plutons. Where partial melting of the amphibolite 
occurred, the first melt to form was tonalitic, crystallizing as quartz, oligoclase, and minor hornblende, reflecting its undersaturation in alumina.

Migmatites resembling those in the Balnacraig GCR site also occur within the Queen's Hill Formation to the south-west of the Ballater Pluton, where they have been described as the Pannanich Hill Complex (Goodman, 1994; see the Cairn Leuchan to Pannanich Hill GCR site report). There, garnetiferous oligoclase-biotite gneisses contain refractory inclusions showing peak regional metamorphic assemblages. The gneissose matrix is considered to have formed by reconstitution of semipelitic lithologies, aided by the presence of abundant aqueous fluids and high temperatures. Peak metamorphic conditions were estimated at $820^{\circ} \mathrm{C}$ and 8 kbar (Baker and Droop, 1983). Partial melting was considered to be likely under those conditions. More conclusive evidence of partial melting of similar metasedimentary rocks was obtained by Goodman and Lappin (1996) from the aureole of the Lochnagar Pluton, where intrusion of dioritic magma followed by granite magma into high-grade regional metamorphic rocks produced temperatures of up to $750^{\circ} \mathrm{C}$ at $2.5 \mathrm{kbar}$ pressure in the aureole. Temperatures in the Balnacraig rocks would have been comparable to those in the Pannanich Hill Complex during the D3 metamorphic peak due to the proximity to the Tarland basic intrusion, so at least some partial melting could be expected.

The polyphase nature of the metamorphism was demonstrated by Baker (1985), who found that andalusite, where present, always post-dated sillimanite, indicating that pressures were significantly lower during the later metamorphic episodes. Two specimens of gneissose pelite from Balnacraig gave results of $762^{\circ} \mathrm{C}$ at $7.6 \mathrm{kbar}$, and $799^{\circ} \mathrm{C}$ at 9.2 kbar for the main metamorphic event, similar to those at Pannanich Hill.

\subsection{Conclusions}

The Balnacraig GCR site is of national and possibly international importance as an exceptional example of the enhancement of the effects of regional metamorphism by the emplacement of basic magma shortly after the regional peak. Many classical features of migmatization of metasedimentary rocks are displayed, including veining by a granitic leucosome and the formation of xenoliths of refractory compositions within irregularly layered gneisses. The migmatization was a result of partial melting of the rocks during the local D3 phase of deformation, which occurred shortly after the regional metamorphism had reached its peak in the upper amphibolite facies. This deformation was contemporaneous with the intrusion of basic magma (the Tarland Intrusion), which might have increased the heat flux sufficiently to cause a local increase in the proportion of partial melt.

A striking feature of the gneisses is the presence of large prismatic crystals of sillimanite that formed during the peak of metamorphism. Later retrograde metamorphism at lower pressure resulted in the growth of andalusite, and the well-preserved mineral assemblages from this GCR site have contributed significantly to a study of variations in temperature and pressure 
during metamorphism in this part of the Grampian Highlands. Possible further research could include an investigation of variations in mineral compositions between the xenoliths and their host rocks, and a comparison with similar metasedimentary rocks near the eastern contact of the Morven-Cabrach Pluton.

\section{MUCKLE FERGIE BURN (NJ $164 \quad 140-$ NJ 167 139)}

\section{J.R. Mendum}

\subsection{Introduction}

The lower part of the Muckle Fergie Burn, a tributary of the River Avon $5 \mathrm{~km}$ south of Tomintoul, cuts through the basal units of the Islay Subgroup, which here include several metamorphosed diamictite beds that are readily correlated with the Port Askaig Tillite of Islay and the Schiehallion Boulder Bed of Perthshire. This section, together with other occurences in Upper Donside and farther north to within sight of the Banffshire coast, shows that the tillite unit recognized at the base of the Argyll Group in Connemara, Donegal and Islay can also be traced through the Grampian Highlands. The tillite unit was probably deposited over a relatively short period of geological time; hence, it is effectively considered to be a chronostratigraphical marker unit within the Dalradian succession. In addition, the section below the tillites in the Muckle Fergie Burn preserves the earliest record of mafic volcanism in the Argyll Group, whilst farther east in the section tuffs and lavas are also found higher in the Islay Subgroup and in the Easdale Subgroup (Figure 14).

The Muckle Fergie Burn section was first described by L.W. Hinxman during primary mapping for the Geological Survey in 1888-9. He recognized the existence of a 'boulder bed' akin to that described near Schiehallion and recorded the presence of granitic and dolomitic clasts in a greenish grey, sandy to silty matrix in the brief memoir for sheet 75 (Hinxman, 1896). Gregory (1931) also included a description of the unit in his book on Dalradian Geology. Both authors failed to attribute a glacial origin to the beds, interpreting them as pebbly calcareous psammites. Morgan (1966) carried out more-detailed mapping over a wide part of the Muckle Fergie-Inchrory area and provided detailed descriptions of the stratigraphy and structure. Then, following the recognition of the glaciomarine origin of the Port Askaig boulder bed (Kilburn et al., 1965), Spencer and Pitcher (1968) extended the correlation and interpretation to the Muckle Fergie Burn section and published a stratigraphical log, as well as noting metadiamictite occurrences farther north-east near Fordyce. The Geological Survey remapped the area in the 1980's during the revision of 1:50 000 Sheet 75W (Glenlivet, 1996) and this description uses material gathered during that work.

Spencer and Pitcher (1968) recognized the wider importance of metadiamictite units with regard to correlation along the whole Dalradian outcrop and more widely in the North Atlantic region, a 
concept that was extended to a worldwide scale by Hambrey and Harland (1981). A tentative correlation has long been made between the Port Askaig Tillite and the Varanger tillites of northern Norway (Spencer, 1971). Recent Rb-Sr illite age dating has bracketed deposition of the Varanger glacial deposits between 620 and $590 \mathrm{Ma}$ (Gorokhov et al., 2001; Bingen et al., 2005), which is more comparable with the top of the Argyll Group than the bottom. Hence, more-recent suggested correlations are with the older Marinoan (c. $635 \mathrm{Ma}$ ) or Sturtian (c. $720 \mathrm{Ma}$ ) glaciations. (See Stephenson et al., 2013a for a full discussion.)

\subsection{Description}

The lower part of the Muckle Fergie Burn flows through a wooded and shrubby gorge, some $240 \mathrm{~m}$ south of Auchnahyle. The burn provides a reference section for the Auchnahyle and overlying Kymah Quartzite formations (Islay Subgroup) and in its upper part passes through the overlying semipelitic, pelitic and basic metavolcanic units of the Easdale Subgroup. Generally the sequence dips at $30-70^{\circ}$ to the east and is the right way up, although some overturned sections are present locally. Medium-scale, close to tight folding repeats some of the 'boulder bed' units.

The metadiamictite beds lie within the Auchnahyle Formation, an interbedded sequence of psammites and semipelites containing amphibolites in the lower part and beds of metalimestone and metadolostone in the upper part. The formation maps out as a lensoid unit, faulted out on its northern margin, whose strike length is about $2 \mathrm{~km}$ and maximum thickness is of the order of 150 to $200 \mathrm{~m}$ (Figure 14). The contact of the Auchnahyle Formation with the underlying Glenfiddich Pelite Formation of the Blair Atholl Subgroup is not exposed in the Muckle Fergie Burn. However a rapid transition from graphitic pelites and semipelites conformably up into amphibolites is seen on a rocky bluff at NJ 163 143, some 300 $m$ to the north.

The exposed burn section (Figure 14) starts with $7 \mathrm{~m}$ of dark greygreen amphibolite that contains two cleavages and prominent quartz and minor calcite veining. Tightly folded, thin- to medium-bedded psammites and semipelites overlie the amphibolite and within these beds (at NJ 1647 1401) is a prominent coarse- to medium-grained amphibolitic unit with an internal structure resembling pillows. No vesicles are seen but the 'pillow structures' do contain radial cracks and show a crude textural zonation; features indicative of lavas. The micaceous and feldspathic psammite and semipelite sequence immediately upstream from the pillowed amphibolites contains some lenticular siliceous psammite units. Several psammite beds show cut-offs and grading implying younging to the east. A c. 4 m-thick sheet of foliated metadiorite intrudes the psammite-semipelite sequence here.

At NJ 16551399 a c. 4 m-thick, thinly banded, grey, fine-grained crystalline metalimestone with thin biotite-rich pelitic interbeds is seen. Upstream for some $15 \mathrm{~m}$, graphitic pelite and minor thin metalimestones are present in the thinly bedded psammite-semipelite sequence. They are succeeded by a c. 6 m-thick cream- to fawnweathering, mottled white and pink, fine- to medium-grained 
metadolostone, which has a rubbly fragmental zone at its top. It passes up into a c. 5 m-thick, unbedded, grey-green, amphibolebearing, highly micaceous psammite containing subangular to subrounded rusty brown-stained metadolostone clasts in its upper part. The metadolostone clasts are deformed with elongations as high as 7:1. This metadiamictite unit and others upstream are notably pyritic. A thin psammite bed separates the lower metadiamictite from the succeeding 5-7 m-thick metadiamictite that contains moderately abundant granitoid and metadolostone clasts in a slightly purplish grey matrix of highly micaceous psammite. These units are succeeded by psammite and a further 6 m-thick metadiamictite with quartz and rare granitoid pebbles and cobbles.

A thicker sequence of psammites follows eastwards. The lowest unit is an indurated recrystallized quartzite with pyrite and minor chlorite giving it an unusual translucent dark bluish green-grey colour, but the higher parts vary from pink siliceous psammite to feldspathic and micaceous psammite. Thin amphibolite sheets are present. A further 4-5 m-thick metadiamictite unit is exposed at the second waterfall (at NJ 1657 1396). It contains scattered granitoid clasts in a grey-green amphibole-bearing semipelitic matrix grading up to a grey semipelite with small metadolostone clasts (Figure 15). A 4 m-thick sheet of metadiorite could be the same intrusion as that seen in the lower part of the section. An upper metadiamictite, some $5 \mathrm{~m}$ thick and consisting of green-grey highly micaceous psammite with scattered small granitoid and rare metadolostone pebbles, occurs at NJ 16611395.

There is a lack of exposure for some $300 \mathrm{~m}$ in the burn section above this lower part until the more-massive cross-bedded siliceous psammite of the Kymah Quartzite Formation is reached. This forms a major scarp feature with the prominent small crags of Sidh Beag and Sidh Mòr above the burn (Figure 14).

The metadiamictite units are invariably matrix supported. The matrix is normally a highly micaceous psammite, which in thin section is seen to be markedly inequigranular with angular to subrounded clasts of quartz, plagioclase and potash feldspar, and clots of chlorite, partly overgrown by biotite. Apatite is a common accessory and zircon is also present. The matrix is dominated by chlorite but locally it is rich in carbonate or amphibole, the latter now mainly altered to chlorite and biotite. The matrix is normally structureless, although a crude ill-defined lamination can be discerned in places.

The majority of clasts are of pebble size with a few cobbles up to $26 \mathrm{~cm}$ and a white granite boulder some $41 \mathrm{~cm}$ by $26 \mathrm{~cm}$ was recorded by Morgan (1966). White to pale-yellow metadolostone is the predominant sedimentary variety of clast, although grey metalimestone (Blair Atholl Subgroup), quartzite, gritty psammite and slate have also been recorded (Gregory, 1931; Morgan, 1966). The igneous clasts are largely granitic and range from white to pink granite to quartz-syenite and granodiorite, with diorite less abundant.

Although the exposure in the Muckle Fergie Burn does not allow full documentation of the structure, open to tight minor folds are seen at various points and bedding dips range from near horizontal to near vertical, implying the presence of small- and medium-scale 
folds. Minor fold axes plunge gently to the south-east, corresponding approximately with a lineation (L2). A crenulation cleavage (S3) that dips steeply to the north-east is developed locally in the more-pelitic units (Morgan, 1966). Two major fold phases (F2 and F3) are well displayed in Blair Atholl Subgroup metalimestones in the Little Fergie Burn $3 \mathrm{~km}$ to the south-southeast, where F2-F3 fold interference patterns are present. There, F2 and F3 fold axes mainly plunge gently to the east-south-east, but some $\mathrm{F} 2$ axes plunge gently to the north-west.

\subsection{Interpretation}

The true thickness of the Auchnahyle Formation in the Muckle Fergie Burn is unclear. Morgan (1966) alluded to repetition by folding, but confusingly included the repetition in his stratigraphical sequence. Similarly, the stratigraphical log given by spencer and Pitcher (1968) shows nine metadiamictite beds, but does not allow for or even reflect the fold repetition. Allowing for dips varying from $30^{\circ}$ to near vertical, the sequence would be $250 \mathrm{~m}$ to $280 \mathrm{~m}$ thick, but fold repetition probably reduces this to nearer $150 \mathrm{~m}$.

The metadiamictite beds are interpreted as marine glacial tillites (Spencer and Pitcher, 1968) and are correlated with the moreextensive and less-deformed Port Askaig Tillite Formation documented by Spencer (1971) from Islay and the Garvellach Islands (see the Garvellach Isles GCR site report in Tanner et al., 2013a). The lowest fragmental metadolostone unit represents the start of glacial deposition in this area, recording the scouring of the immediately underlying unit, presumeably by ice and/or meltwater. The overlying tillite bed contains some metadolostone clasts but also includes granitoid cobbles and represents input from a wider area.

Abundant amphibolite sheets and some amphibole-rich metadiamictite units occur in the upper part of the succession, whereas thicker amphibolite sheets and basic pillow lavas are found below the metadiamictite beds. These features, together with the ubiquitous presence of pyrite, suggest that input from a mafic volcanic source coincided with the glacial episode. Much of this altered amphibolitic material could be derived either from erosion of basic volcanic units or relate directly to volcanic activity. In the Ladder Hills area to the north-east, the lowest Islay Subgroup sedimentary sequence is considerably thicker than in the Muckle Fergie Burn and tuffaceous and lava units occur within the turbiditic psammite-semipelite succession (see the Kymah Burn GCR report). This volcanic association is prominent only in the tillite units of the North-east Grampian Highlands (Harris et al., 1994; Fettes et al., 2011).

There is also a close association of metadiamictite with metadolostone units in the Muckle Fergie Burn, in Upper Donside and in the Ladder Hills, suggesting that the dolomitization and glaciation are closely related.

The tillite unit is generally accepted to be a chronostratigraphical marker and could have formed at either c. 635 $\mathrm{Ma}$ (Marinoan tillites) or at c. 723 Ma (Sturtian tillites). Adoption of either age creates problems in trying to understand the 
depositional history and palaeogeography of the Dalradian succession. The older age allows little time, possibly only $30 \mathrm{Ma}$, for the deposition of the Grampian and Appin groups but gives a period of c. $120 \mathrm{Ma}$ for the deposition of the Argyll Group. The more likely younger age, however, allows 120 Ma for deposition of the Grampian and Appin groups and c. 30 Ma for deposition of the Argyll Group (see Stephenson et al., 2013a).

\subsection{Conclusions}

The lower part of the Muckle Fergie Burn section contains several poorly sorted, matrix-supported 'boulder beds', similar to those found near the base of the Argyll Group at Schiehallion, the Garvellach Isles and on the Isle of Islay. The 'boulder beds', moreprecisely termed 'metadiamictites', represent marine glacial tills and form a small relict fragment of a unit that can be traced intermittently from Connemara in the west of Ireland to the Banffshire coast. They record the presence of glacial conditions during a finite time period in the late Neoproterozoic and hence form a chronostratitigraphical marker unit that is possibly the most reliable and the most widespread in the whole Dalradian succession; the Muckle Fergie Burn provides the most north-easterly detailed section through this crucial unit.

In the Muckle Fergie Burn section, the lowest metadiamictite rests upon an erosion surface and is dominated by clasts of metalimestone and metadolostone that were most likely derived quite locally from the underlying Appin Group rocks. But, as is the case elsewhere, higher metadiamictites contain an increasing proportion of granitic clasts reflecting a much more-widespread source area.

The section also contains poorly preserved pillow lavas, which provide evidence of basic volcanism coeval with the glaciation. Not only is this the only area in the whole strike length of the tillite unit where volcanic rocks are found but it is also the earliest evidence for basic igneous activity anywhere in the Dalradian succession; volcanism subsequently continued throughout Argyll Group and much of Southern Highland Group times.

These tillites and related lithologies clearly consititute vital evidence for a major glacial period in the Earth's history and hence are of great international importance. Much interest is currently focussed upon correlation with other, dated, glacial deposits in the North Atlantic region and worldwide. Possibilities include the Marinoan tillites at c. 635 Ma or even the Sturtian tillites at c. $723 \mathrm{Ma}$. The correlation has vital implications for the history of Dalradian sedimentation and for global reconstructions of the Neoproterozoic Era. 


\section{BRIDGE OF BROWN \\ (NJ $12002117-N J 1269$ 2019)}

\section{J.R. Mendum}

\subsection{Introduction}

The river section at Bridge of Brown, on the A939 between Tomintoul and Grantown-on-Spey, provides one of the few coherent sections through the transition from the Grampian Group up into the Appin Group. The section spans the uppermost psammite and quartzite units of the Grampian Group, the interbedded psammites, semipelites and highly calcareous semipelites of the Lochaber Subgroup, and lower Ballachulish subgroup metalimestone, calcareous semipelite, and graphitic pelite-semipelite units. Within the Lochaber subgroup is a distinctive gneissose kyanite-garnet-muscovite-biotite semipelite unit that can be traced northwards as far as the Banffshire coast. The sequence is deformed but no evidence is seen for a major slide, such as occurs at this stratigraphical level in the Schiehallion and Glen Tilt areas of Perthshire to the south-west.

The Bridge of Brown GCR site is complementary to the adjacent Bridge of Avon GCR site in that it extends the stratigraphical section down through the lower part of the Appin Group and into the Grampian Group. It also continues the structural cross-section to a lower level. The bedding dips moderately to the south-south-east throughout the section and, although minor folds are seen locally, there is no evidence for significant fold repetition or inverted bedding. Similarly, although the bedding appears to be somewhat attenuated, lineations and strong planar fabrics are conspicuously absent. The transition from the thick, competent, lithologically relatively uniform, psammite-dominated Grampian Group to the mixed pelite-metalimestone-quartzite Appin Group sequence must act as a focus for enhanced deformation. An early slide is interpreted to lie at or near the base of the Ballachulish Subgroup over much of the Glenlivet district to the south but in the Burn of Brown section only a small part of the stratigraphy appears to be excised. South of the Cairngorm Granite Pluton, ductile sliding is focussed along the Grampian-Appin group boundary (see the Glen Ey Gorge and Gilbert's Bridge GCR site reports) and farther north around Ben Rinnes mylonitic rocks are also developed at this level. On the Banffshire Coast section, west of Sandend a stratigraphical transition is well seen (see the Cullen to Troup Head GCR site report), but there the Lochaber Subgroup is abnormally thick.

The Bridge of Brown area was originally mapped by L.W. Hinxman during the primary geological survey but was not deemed worthy of particular mention in the sheet 75 memoir (Hinxman, 1896). The area was remapped by the Geological Survey as part of the revision of the bedrock geology of the Glenlivet district (1:50 000 sheet 75W, Glenlivet, 1996) and that work forms the basis for this account. 


\subsection{Description}

The Burn of Brown flows through a narrow incised gorge, where the original, General Wade road crossed the burn; the more-recent road bridges occur a few hundred metres downstream (Figure 16). The incised section probably represents capture of the Glen Brown drainage basin by the Burn of Lochy, with the former drainage flowing eastwards to the River Avon via Fodderletter.

\subsubsection{Stratigraphy}

The Grampian Group rocks are seen near the ruin of Blàr an Lochain (NJ 1213 2110), where they comprise feldspathic, siliceous and micaceous psammite with semipelite interbeds with rare calcsilicate-rock lenses and lenticular bands. These mixed lithologies form part of the Strathavon Psammite Member of the Tormore Psammite Formation. Individual semipelite units reach 2 to $3 \mathrm{~m}$ in thickness and show evidence of two penetrative cleavages. The semipelites contain garnet, muscovite and biotite and the calcsilicate-rock lenses contain garnet and hornblende. These metamorphic mineralogies are characteristic of the lower amphibolite facies. Upstream, at around NJ 1207 2100, thin- to medium-bedded psammites are dominant with bed thicknesses normally ranging from $2 \mathrm{~cm}$ to $30 \mathrm{~cm}$, but reaching up to $50 \mathrm{~cm}$ in the coarser grained units. Good examples of cross-bedding and slump folds with prominent cut-offs show that the beds are right way up. Slump fold axes plunge to the south-east. Upstream, thinly bedded feldspathic and micaceous psammites with minor semipelite beds and partings are dominant with thin quartzite beds present locally.

Just below Bridge of Brown, flaggy, thinly bedded to laminated semipelite and micaceous psammite become dominant and constitute the basal Lochaber Subgroup unit, the Dalvrecht Slate Formation. These rocks have a strong penetrative planar fabric and a slaty parting. In thin section they contain quartz, plagioclase feldspar, muscovite and biotite, with garnet common in parts. The abundant micas define three separate cleavages in some of the specimens. Thin bands of calcsilicate rock are also present. Between the present bridge and the Wade bridge greenish grey micaceous and highly micaceous psammites with minor calcsilicaterock bands crop out. They pass upstream into flaggy, sparsely garnetiferous, micaceous psammites with thin siliceous psammite interbeds. Calcsilicate-rock bands are common and quartz veins are present. The Dalvrecht Slate Formation is some $120 \mathrm{~m}$ thick here.

Upstream the beds become grey-green in colour and consist of thinly bedded but lithologically more-uniform, calcareous semipelite and highly micaceous psammite with abundant lenses of white and green calcareous quartzite. Locally the calcsilicaterock lenses overgrow bedding features showing that they were formed during diagenesis or perhaps even later. In parts darker green amphibolitic beds (originally marls) are seen. These calcareous units constitute the Fodderletter Calcareous Flag Formation. In thin section the calcsilicate rocks contain much tremolite but relict diopside is present locally. At NJ 1266 2034, a massive gneissose kyanite-muscovite-biotite-(garnet) semipelite bed, some 5 
m thick, forms a small waterfall. This is the Fireach Beag Kyanite Gneiss Member and contains elongate laths of blue-grey kyanite up to $2 \mathrm{~cm}$ long. Under the microscope the gneiss consists of coarsegrained, well-formed muscovite laths intergrown with more-ragged biotite enclosing coarse-grained aggregates of quartz and plagioclase (oligoclase). Kyanite forms laths up to $5 \mathrm{~mm}$ long and is partly altered to fine-grained muscovite with chlorite common locally. Garnets are altered to quartz-feldspar-biotite-ilmenite aggregates and fractured staurolites up to $1 \mathrm{~mm}$ long are present. Ilmenite is common and rutile, apatite and tourmaline are also present. Above the gneiss the formation is lithologically more variable and consists of thinly bedded calcareous and noncalcareous micaceous psammites, semipelites and biotitic pelite units. Calcsilicate-rock units remain abundant and are locally pyritic. At NJ 1267 2027, graded units are seen and possible slump folds occur at NJ 1268 2023. The highest lithology exposed in the GCR site consists of slaty micaceous psammite and semipelite, which show tight folding locally. The overlying Mortlach Graphitic Schist Formation is not exposed in the burn section but a block of silicified metalimestone has been recorded in the nearby till and graphitic pelite that characterizes the formation is seen widely in the float, together with dark-grey tremolitic material representing graphitic calcareous mudstone.

\subsubsection{Structure}

The Grampian and Appin group units form an ordered succession that dips between 20 and $45^{\circ}$ to the south-east. Although minor folding has duplicated the succession locally, the sequence is essentially right way up and youngs to the south-east (Figure 17). The best examples of tight $F 2$ folds and open to tight $F 3$ folds are seen in the interbanded psammites and semipelites of the Grampian Group at the northern end of the section. Above the Allt an Doruis, at NJ 168 2139, gritty quartzite beds and intervening semipelites are tightly folded, with the axes of tight recumbent F2 folds plunging gently to the east-north-east and axial planes dipping moderately to the south-east. A quartz mineral lineation also plunges gently to the east-north-east, near-coincident with the F2 axes. The fine S2 cleavage is best seen in semipelite units in the F2 hinges. Higher in the stratigraphy, very little evidence is seen for minor F2 folds, with only isolated examples reported. The F3 folds vary from open to tight and are also best seen in the mixed Grampian Group lithologies. Examples are recorded at the Allt an Doruis and around NJ 1198 2109, where layers of calcsilicate rock show excellent NW-verging close F3 folds, whose axes plunge gently to the north-east. A penetrative axial plane crenulation cleavage that dips steeply to the south-east is developed in the adjacent semipelite layers. The F3 folds refold an earlier easterly plunging L2 lineation.

Although minor folds are rare in the Lochaber subgroup rocks, several cleavage generations can be recognized in hand specimen and in thin section these show discordant relationships. In the laminated psammite-semipelite units of the Dalvrecht slate Formation, an early fine-scale mica cleavage, S1, is preserved 
locally in the 0.5 to $2 \mathrm{~mm}$ microlithons between the dominant spaced muscovite-rich lamellae that form the main S2 spaced/crenulation cleavage. In some specimens a later cleavage, defined by muscovite laths, lies markedly discordant to the earlier fabrics. This S3 cleavage can relate to open to close minor folds. Generally all three cleavages dip more steeply than bedding. Garnets, where present, contain inclusion trails of the S1 cleavage and apparently pre-date the $\mathrm{S} 2$ cleavage. In the more-slaty units, by Bridge of Brown, minor F4 kink folds are also sparsely developed. Recorded F4 axes plunge gently east and south-west.

Peak metamorphic conditions were attained during the D2 deformation, and in this area they reached temperatures of 620 to $650^{\circ} \mathrm{C}$ and pressures of 8 to 8.5 kbar (Beddoe-Stephens, 1990). These conditions lie close to the upper limits of the lower amphibolite facies.

\subsection{Interpretation}

The Grampian Group rocks represent shallow-marine shelf-sands and subsidiary silts with material being repeatedly reworked. The presence of cross-bedding and slump structures attests to the presence of strong currents and at least locally, relatively rapid deposition. The transition to Appin Group rocks is marked by the incoming of more-intermixed psammite and semipelite and calcareous lithologies that make up the Lochaber Subgroup. It signifies basin shallowing and regression in this area with some possible emergent areas, although in the Northern Grampian Highlands, Banks (2005) has suggested that the semipelitic and pelitic elements represented more-distal deposition during a moderate transgression. The quartzitic units are interpreted as a product of reworking of the underlying succession, rather than input of additional sand material. The Fireach Beag Kyanite Gneiss, which forms a marker unit, represents aluminous mud and silt, possibly representing input of tropically weathered material derived from the nearby source area.

Elsewhere in the Dalradian succession, block uplift appears to have created local unconformities in the Lochaber subgroup succession, and in extreme cases the entire subgroup is absent (see Treagus et al., 2013). Although the presence of gaps in the succession at Bridge of Brown cannot be ruled out, there is no evidence for significant gaps in the lithostratigraphy. The Fodderletter Calcareous Flag Formation occupies a similar position in the stratigraphy to the Leven Schist Formation of Glen Spean and Appin and the Baddoch Burn Striped Pelite of Glen Shee. It presages the incoming of the Ballachulish Subgroup, indicative of a more-widespread transgression that covered most of the upstanding blocks (Banks, 2005).

The Grampian-Appin group boundary throughout much of Perthshire is marked by a zone of very highly attenuated Appin and Argyll group rocks that form a major NNW-verging D2 shear-zone, termed the 'Boundary Slide' (see the Allt Druidhe, Strath Fionan, Gilbert's Bridge and Glen Ey Gorge GCR site reports). In those areas, the position of the slide might also reflect an original unconformity or a basement lineament. The tectonics of the North-east Grampian 
Highlands are somewhat different and shear-zones are found within several parts of the Grampian, Appin and Argyll group succession, mostly reflecting thrusting to the north-west during the major Grampian D2 event. Although the Grampian-Appin group boundary does represent a major lithological competence contrast, it is not coincident with a single, laterally continuous major shear-zone and in many places, particularly towards the north coast, there is no shearing or dislocation at all. At Bridge of Brown, although there is evidence of increased strain and even localized shearing in the Lochaber Subgroup rocks, no specific Boundary Slide-type structure is present.

\subsection{Conclusions}

The Bridge of Brown GCR site demonstrates the transitional nature of the contact between Grampian Group and Appin Group strata in the North-east Grampian Highlands. Here, there is no major shear-zone or dislocation at this junction, in marked contrast to the situation in Perthshire, where the Boundary Slide is recognized.

Structurally the rocks are relatively simple in that the succession dips moderately to the south-east and the beds become younger in that direction. The Grampian Group rocks are psammites and subsidiary semipelites that show cross-bedding and slump structures indicative of shallow-marine shelf deposition. Where lithologies are mixed, two sets of folds and related cleavages are developed. They pass upwards into thinly interbedded psammites and semipelites with thin quartzites that mark the lowest beds of the Lochaber Subgroup. These beds are attenuated and show evidence of three cleavages and increased strain. They are succeeded upwards by calcareous semipelites and micaceous psammites with abundant bands and lenses of calcsilicate rock, minor graphitic pelite and some thin quartzite beds. These lithologies show very little internal structural complication but they do contain a prominent massive gneissose kyanite-muscovite-biotite-garnet semipelite unit that can be recognized as a marker bed in several parts of the North-east Grampian Highlands.

This site is complementary to the Bridge of Avon GCR site, which effectively extends the cross-section to the south-east. It also provides an important reference site between the complex geometry of the Boundary slide in Perthshire and the enhanced stratigraphical sequence of the Banffshire Coast.

\section{BRIDGE OF AVON} (NJ 1497 2032-NJ 1541 1915)

\section{J.R. Mendum}

\subsection{Introduction}

The River Avon and adjacent areas around Bridge of Avon, $2 \mathrm{~km}$ north-west of Tomintoul, expose sections through the Ballachulish and Blair Atholl subgroup rocks that here are disposed in kilometre-scale fold patterns. The sequence includes several very 
distinctive units that can be recognized not only throughout the North-east Grampian Highlands but also along most of the Dalradian outcrop elsewhere and hence are valuable stratigraphical markers.

Here, the stratigraphy is condensed and probably represents deposition over an original basin high. The Ballachulish Subgroup sequence ranges from graphitic pelite of the Mortlach Graphitic Schist Formation up through the Corriehabbie Quartzite Formation to the mixed Ailnack Phyllite and Limestone Formation. The Inchrory Limestone Formation represents the overlying Blair Atholl Subgroup rocks. Although the lithologies are deformed and metamorphosed to kyanite grade (lower amphibolite facies), they clearly show internal bedding features in parts e.g. cross-bedding in the quartzite and grading in some of the semipelitic units.

The structure of the Dalradian rocks is complex and four deformation phases can be recognized. Bedding generally dips moderately to the south and south-east but dips vary from $25^{\circ}$ to vertical locally. Cleavages are best seen in the more-pelitic units, notably in the graphitic pelite. Minor folding is well displayed in the thinner bedded units, notably in the calcareous semipelite and psammite. A set of faults that mainly trend northsouth disrupt the structural pattern. These faults are of Devonian and later age, as several of them affect the conglomerates and sandstones of the late Silurian to Early Devonian Tomintoul Outlier, which overlie the Dalradian rocks about a kilometre south of the GCR site.

The Bridge of Avon area was mapped by L.W. Hinxman during the primary geological survey and brief descriptions were given in the Sheet 75 memoir (Hinxman, 1896). Hinxman mapped the area solely on the basis of lithology and in some areas his map linked together several stratigraphically disparate units. The area was remapped by the British Geological Survey between 1982 and 1988 (1:50 000 Sheet 75W, Glenlivet, 1996), and that work forms the basis for this account. A detailed geochemical study of Dalradian metacarbonate units by Thomas (1989, 1999) included several samples from the Bridge of Avon area.

\subsection{Description}

The Bridge of Avon GCR site encompasses some $1.4 \mathrm{~km}$ of the River Avon section, extending from downstream of the old General Wade bridge, up river almost to below the abandoned lime quarry at Creag Chalcaidh. It also includes the lowermost part of the Allt na cluaine and some small crags marginal to alluvial terraces. Exposure is not continuous but amalgamation of all the information available gives a moderately comprehensive picture of the geology (Figure 18).

\subsubsection{Stratigraphy}

The Mortlach Graphitic Schist Formation forms the core of an F2 anticline that is mapped mainly from the float on Tom Beag, westsouth-west of Bridge of Avon. Poor exposures are seen in the river section on its west bank. It consists mainly of dark-grey, to nearly black, schistose graphitic pelite and semipelite, with small 
garnets abundant in parts. Pyrite and quartz veins are also abundant locally and in thin section kyanite and staurolite porphyroblasts are common. The dominant parting is a millimetrescale penetrative spaced cleavage (S2). The earlier fine-grained S1 fabric, which generally lies near-parallel to bedding, is seen only in thin section. The formation shows a rapid transition upstream into the Corriehabbie Quartzite Formation, a white to fawn, blocky, commonly indurated, fine- to coarse-grained quartzite, with minor siliceous and feldspathic psammite. It is thin to medium bedded with some gritty feldspathic basal zones in individual sand units. Cross-bedding is present locally, defined by heavy-mineral streaks (magnetite/haematite). Around Bridge of Avon the quartzite formation is only about $55 \mathrm{~m}$ thick but it thickens to over $250 \mathrm{~m}$ a few kilometres to the north-east and farther south in the Water of Ailnack section. The outcrop pattern of the quartzite is convolute in the area north-west of Tomintoul as a result of both F2 and F3 kilometre-scale folding. These give rise to the interference structures seen in plan on Figure 18, which together with the initial thickness variations and later faulting, result in a complex structural pattern. Some of the step-like offsets of the quartzite outcrop around Bridge of Avon are a product of local F4 folding.

The overlying Ailnack Phyllite and Limestone Formation consists of psammite, semipelite, metalimestone and minor pelite lithologies. Calcsilicate rocks are characteristic of parts of the formation and thin quartzite beds commonly occur near its base. An across-strike section occurs beneath the Bridge of Avon itself (NJ 1495 2015) but the unit forms a complex outcrop pattern in this area. It contains some prominent members that can be recognized widely on sheet $75 \mathrm{~W}$ (Glenlivet). At the base of the formation lies the Torulian Limestone Member, which here forms a prominent, almost pure white unit c. $5 \mathrm{~m}$ thick. Its outcrop can be traced from the bank into the rocky bed of the river, where it is cut out against a fault. The metalimestone consists dominantly of calcite with pyrite-rich laminae. It shows a poorly defined, thin banding that has been etched out by the river to show tight to isoclinal folds with amplitudes of up to $2 \mathrm{~m}$. Their axial planes lie subparallel to the bedding, and the folds are confined to individual layers, in parts truncated by overlying thin beds. They are interpreted as slump folds but could be Fl structures.

The metalimestone member is succeeded by phyllitic semipelite and pelite, in parts graphitic, which is followed by thinly banded calcareous semipelite, calcsilicate rock and impure metalimestones that show good examples of F3 minor folding. These latter lithologies are exposed directly beneath the Wade bridge. They pass upwards into the more-semipelite-dominated upper part of the Ailnack Phyllite and Limestone Formation, which here is distinctive enough to be termed the Kylnadrochit semipelite Member. This unit is about $65 \mathrm{~m}$ thick, and consists of purplish and greenish midgrey, flaggy to blocky, calcareous, highly micaceous psammite and semipelite. The beds are laminated to thinly banded, commonly with retrogressed garnet porphyroblasts. They are folded by open to tight F3 folds that have attenuated limbs and a related penetrative s3 planar cleavage; they verge mainly to the south-west. In the 
lower part of the Allt na Cluaine section, between NJ 14751932 and NJ 1494 1937, more-pelitic and graphitic lithologies at the top of the member are exposed. These are charcoal grey to blue-grey, flaggy to fissile, calcareous semipelite and pelite with abundant small garnet porphyroblasts. Tight folding is present, but in the semipelitic units good fine-scale grading has been recorded. These uppermost lithologies are probably equivalent to parts of the Clashnoir Semipelite Formation, which is mapped as a separate unit in the Blair Atholl Subgroup to the north-east in the Braes of Glenlivet, where the sequence is considerably thicker.

In the Bridge of Avon area, the Kynadrochit Semipelite Member passes up by rapid transition into the Inchrory Limestone Formation, the main metalimestone unit of the Blair Atholl Subgroup. Transitional lithologies consisting of interbedded calcareous semipelite, graphitic pelite and grey crystalline metalimestone are seen below Urlamore at NJ 15071998 and in crags east of the A 939 road at NJ 1506 1967. In the Campdalmore area, north-west of Tomintoul, the Inchrory Limestone Formation appears to be notably thick (c. $430 \mathrm{~m})$, but where seen in the Creag Chalcaidh Lime Quarry (NJ 156 194), it contains numerous tight to isoclinal minor and medium-scale folds. The overall outcrop pattern also implies fold repetition and its true stratigraphical thickness is estimated to be closer to $150 \mathrm{~m}$. The unit is composed of blue-grey, flaggy to massive, fine- to coarse-grained (typically $2 \mathrm{~mm}$ grain size), crystalline metalimestone, normally thinly to thickly bedded or banded. The finer grained variants are mid to dark grey, whereas the coarser grained metalimestones are pale bluish grey and commonly almost translucent. Laminae and thin interbeds of graphitic pelite are common and pyrite is also abundant. Minor thin siliceous, cherty bands are present locally in the metalimestone, and thicker calcareous semipelite interbeds are also seen. Calcite veining is common, and adjacent to faults the metalimestone is recrystallized. Good exposures are seen in the River Avon section at NJ 1535 1917, where metalimestones with thin graphitic semipelite interbeds exhibit abundant tight F3 folding.

Dark-green amphibolite lenses and pods are seen in parts of the sequence, notably in the Inchrory Limestone Formation and the underlying Kylnadrochit semipelite Member. They appear to crosscut bedding locally but are strongly deformed and commonly boudinaged. They represent metadolerite or metabasalt intrusions and many show metamorphic reaction rims with the adjacent metalimestone. It is unclear as to whether they were intruded early in the geological history, possibly coeval with volcanic units in the Argyll Group, or whether they are linked to the Morven-Cabrach Pluton, which is mid Ordovician in age. A 0.5 to 1 metre-thick boudinaged sheet is seen in semipelites in the Allt na Cluaine at NJ 1488198 and amphibolite pods are abundant in the Inchrory Limestone Formation at NJ 15291917 and at NN 15061966. Larger pods are seen on the north-west face of the Creag Chalcaidh Lime Quarry (NJ 1554 1944). 


\subsubsection{Structure}

The distinctive lithologies in the Bridge of Avon area define a basic refolded F2-F3 fold pattern that is further complicated by the presence of late-stage steeply plunging open folds (F4) and the abundant faulting (Figure 17). The area lies close to the marked 'knee-bend' in the Dalradian succession, defined by the strike of bedding that swings from north-east around the Bridge of Avon and Bridge of Brown GCR sites to south-east farther south (see 1.2.2 in Introduction, Figure 1 and Stephenson et al., 2013a, fig. 1). The vergence of the main folds changes from north-west to south-west respectively around this major structure.

The D1 structure is normally expressed as a bedding-parallel cleavage or schistosity, best seen in thin sections of the moresemipelitic or pelitic rocks. However, tight to isoclinal folds, invariably confined to individual beds or packages of beds, are seen locally, particularly in some of the metalimestone units. It is unclear whether they represent slump folding, convolute bedding or early tectonic deformation. Examples are seen in the Torulian Limestone Member and in the Inchrory Limestone Formation. Where differential weathering has occurred, such folds stand out in the metalimestones, but in quarries and in clean river sections the folds are more difficult to recognize, unless pelitic interbeds are present. In some clean-washed sections stylolites are preferentially seen, e.g. in the River Avon at NJ 15731926 where they are folded. Early formed extensional slides are present in the sequence and a major south-easterly dipping slide does underlie the Bridge of Avon area at shallow depth. The metamorphic grade that accompanied D1 deformation is not known but was probably either greenschist or lower amphibolite facies.

The D2 deformation was penetrative and resulted in the generation of a widespread cleavage and tight folding on both small and medium scales. It was accompanied by middle amphibolite-facies metamorphism, and samples from pelites 1 to $2 \mathrm{~km}$ north-north-west of Bridge of Avon have yielded consistent pressure estimates of 8 to $8.5 \mathrm{kbar}$ and temperature estimates of 620 to $650^{\circ} \mathrm{C}$ (BeddoeStephens, 1990). Minor folds are typically tight but vary from close to isoclinal. F2 fold axes plunge gently to moderately to the south-east and south-south-east, and their axial planes dip moderately to the south-east.

The D3 deformation has resulted in abundant medium- to small-scale folding and local generation of a penetrative or spaced S3 cleavage dependent on the intensity of deformation and lithology. F3 folds refold earlier D2 features but small-scale examples of fold interference structures are only rarely seen. Where the succession is thinly banded, F3 minor folds are abundant (Figure 19). F3 axes plunge gently to moderately to the south-east and south-west and fold axial planes mostly dip moderately to steeply to the southeast, although locally they do show considerable variation in orientation. The folds are typically asymmetrical and generally verge to the north-west and south-west. Accompanying metamorphism attained lower to middle amphibolite-facies conditions.

The D4 deformation was a relatively local event, manifested as steeply plunging medium-scale open folds that affect the outcrop 
pattern around Bridge of Avon and a late-stage steeply dipping crenulation cleavage in the Mortlach Graphitic Schist Formation. Such structures might reflect the unusual structural position of the area, which lies close to the northern termination of a fault system that extends southwards along the valley of the Avon to join the Loch Tay Fault. Alternatively they could reflect an earlier lineament, e.g. the NW-trending Lecht Lineament (Fettes et al., 1986) or the structural high that appears to have controlled sedimentation patterns in this area. The D4 structural event occurred under greenschist-facies conditions, possibly linked to retrogression of the earlier higher grade metamorphic assemblages.

Faulting is abundant in the Bridge of Avon area, which lies at the junction of the roughly N-S-trending fault system that tracks Glen Avon and the NW-trending Lecht Fault-system. The faults appear to be steeply dipping, commonly subvertical, and have associated localized brecciation and alteration. They are Early Devonian or later in age. There is no evidence that these late faults mimic or even reflect the earlier lineaments that controlled sedimentation.

\subsection{Interpretation}

The Dalradian rocks in the Bridge of Avon area show a condensed stratigraphical sequence. Most elements of the Ballachulish and Blair Atholl subgroup successions are represented but there seem to be gaps in the sequence. For example, it is clear that the Torulian Limestone Member overlies the Corriehabbie Quartzite Formation almost directly, whereas in adjacent areas some tens of metres of semipelite and micaceous psammite are present between the two units. As Appin Group units were deposited under shallow marine conditions and can be traced over much of the overall Dalradian outcrop, uniform conditions obviously prevailed over a wide area. Hence, in the Bridge of Avon area, deposition could be interpreted as having taken place over a basin high, albeit with some transitional lithologies being absent, and/or in part of the basin where sediment supply was deficient. The area lies close to the major strike swing of the Dalradian outcrop (the 'knee bend') that is now thought to reflect a lineament that stretched from Deeside to Dulnain Bridge and to have separated parts of the depositional basin. The localized occurrence of quartzites and metalimestones in the Lochaber Subgroup rocks some $5 \mathrm{~km}$ to the west and early-formed slides in the succession all suggest that structural activity occurred during and following deposition and that the basin geometry controlled the local patterns of sedimentation.

Deformation has been focussed on the Bridge of Avon area from early in the geological history. The presence of a slide, whose trace crops out just to the north-west, shows that early extensional movements occurred either during sedimentation of younger Dalradian rocks or early in the tectonic history of this area. The superimposition of $F 2$ and $F 3$ folds in this area has generated a kilometre-scale fold pattern that probably dates from the mid Ordovician and formed part of the Grampian Event of the Caledonian Orogeny. Minor fold orientations and vergence are variable, particularly for the F2 folds, but F2 and F3 vergence is 
mainly towards the north-west. The lower Ballachulish Subgroup units, the Mortlach Graphitic Schist and Corriehabbie Quartzite formations, form an anticlinal outcrop that closes both to the east and the west (a pericline). The major fold closures are defined by F2 anticlines and synclines with the F3 folds effectively corrugating the earlier pattern. The folding results from Grampian deformation of the thin, yet lithologically variable sequence, focussed on a pre-existing lineament. The major change in strike of the Dalradian succession that forms a 'knee-bend' just to the south of the Bridge of Avon area could also reflect the original basin geometry and presence of lineaments (Fettes et al., 1986).

\subsection{Conclusions}

The Bridge of Avon GCR site provides an excellent stratigraphical cross-section through a condensed Appin Group succession that is interpreted as having formed on a high in the original offshore sedimentary basin. Although reduced in thickness, the characteristic lithologies of this Ballachulish and Blair Atholl subgroup sequence are still eminently recognizable and are representative of a large area of the North-east Grampian Highlands. The Ballachulish Subgroup comprises the Mortlach Graphitic Schist Formation, succeeded by the Corriehabbbie Quartzite Formation and the mixed Ailnack Phyllite and Limestone Formation. The overlying Blair Atholl Subgroup is represented in the site area only by the Inchrory Limestone Formation. These units represent alternating deeper and shallower water parts of the succession, providing a record of transgression and regression that is typical of many shallow marine sedimentary sequences.

The sequence has undergone early tectonic sliding and subsequently has been deformed and metamorphosed under lower amphibolite-facies conditions during the Grampian orogenic event in the mid ordovician. Although four phases of deformation can be recognized, only two main sets of folds and related cleavages are widely developed and they provide a good example of a kilometre-scale fold interference pattern. The overall geometry is of NW-verging folding and moderate to steep south-easterly dipping cleavages. However, the area lies close to a regional swing of strike (the socalled 'knee-bend') and change in fold vergence, with the fold structures in the rocks a few kilometres to the south generally verging to the south-west. The Bridge of Avon area forms a natural focal point in the Dalradian outcrop of the North-east Grampian Highlands .

\section{KYMAH BURN}

(NJ $28812304-\mathrm{NJ} 3008$ 2236)

\section{J.R. Mendum}

\subsection{Introduction}

The Kymah Burn is a major headwater tributary of the River Livet, which cuts through the Ladder Hills providing a cross-section 
through the Ladder Hills Formation and overlying Kymah Quartzite Formation of the Islay Subgroup. The section illustrates the varied nature of the stratigraphy at the base of the Argyll Group and the overall fold structure. It is the type section for the Kymah Quartzite Formation. Thin pillow-lava units show that periodic basic volcanism took place during sedimentation.

The Ladder Hills Formation is laterally equivalent to the metadiamictite-bearing Auchnahyle Formation, which lies some $16 \mathrm{~km}$ to the south-west and is described in the Muckle Fergie Burn GCR site report. It consists mainly of interbedded psammite, semipelite and pelite, much of it showing grading and other bedding features typical of turbidite deposition. It also includes some mottled grey, green and cream 'fragmental' units rich in chlorite and epidote, possibly representing tuffaceous units, and rare cream metadolostone beds. Along strike to the south, similar lenticular metadolostone beds are associated with metadiamictite units but no metadiamictites have been reported from the Kymah Burn section. To the south-east, towards Glen Buchat, the upper part of the Ladder Hills Formation passes laterally into a more-pelitic and calcareous unit, the Nochty Semipelite and Limestone Formation. The overlying Kymah Quartzite Formation consists mainly of quartzite and psammite, but includes thin amphibolitic metavolcanic units, which locally show vesicular textures and pillow structures. Basic sheets also intrude the quartzite, and although they are now foliated and metamorphosed to amphibolite, discordant relationships are still visible in places.

The succession has been folded into a kilometre-scale refolded fold, repeating the stratigraphy. As the beds themselves show only low to moderate strain, the structure can be determined from bedding and cleavage measurements and observations, taking cognizance of relatively abundant way-up indicators (grading, cross-bedding, pillow lavas).

The area was first mapped by L.W. Hinxman for the Geological Survey in 1892-3 and it was he who recognized the presence of basic sheets in the quartzite. No further work was done until the area was resurveyed by the British Geological Survey in the mid 1980's as part of the revision of 1:50 000 Sheet 75E (Glenbuchat, 1995).

\subsection{Description}

The Kymah Burn runs through an incised gorge in the Ladder Hills, where relief ranges from 150-230 $\mathrm{m}$ in the lower part, overlooked by the crags of The Eachrach, to c. $100 \mathrm{~m}$ in the higher parts of the section. Although there is a reasonable coherent bedrock section along the burn, the sides of the gorge are mostly scree covered or are obscured by slipped material. To the north of the gorge section, the outcrop of the Kymah Quartzite Formation terminates where it has been intruded and hornfelsed by a small microgranite body. This is part of the immediately adjacent Glenlivet Granite Pluton, which crops out in the lower part of the burn.

The burn section traverses obliquely across the overall strike of the Ladder Hills and Kymah Quartzite formations, which here are disposed in a complex, large-scale, refolded fold pattern (Figure 20). The Ladder Hills Formation consists of cream to fawn and 
pale-grey, thin- to medium-bedded, typically flaggy to blocky, micaceous and feldspathic psammites interbedded with dark-grey pelites and mid-grey semipelites. The psammites commonly show grading, in parts from gritty psammite bases up to semipelitic or even pelitic tops. Graded bedding, load structures, cut-offs and cross-bedding are all seen, indicative of turbiditic conditions during deposition. Locally, deformed thin psammite dykelets occur, indicating dewatering during compaction, and implying rapid deposition of the sand and silt sequence. Beds of graphitic pelite are thin in this section, but elsewhere such units can attain $20 \mathrm{~m}$ in thickness. The base of the Ladder Hills Formation is not exposed in the Kymah Burn but is seen some $3 \mathrm{~km}$ to the south-west by Ladderfoot (at NJ 2663 2066), where there is a transition from the graphitic pelites and semipelites of the underlying Glenfiddich Pelite Formation up into thinly interbedded semipelites and psammites.

Good exposures of the typical Ladder Hills Formation occur in the Kymah Burn between the tributary burns of Caochan Domhain and Caochan Ranaich (Figure 20a). Although cleavages are developed in the pelitic lithologies the beds are not schistose. Here, chloritic material occurs in the basal parts of some psammite beds and amphibole + plagioclase feldspar-bearing 'fragmental' units up to $2 \mathrm{~m}$ thick are also present. These mottled grey-green-fawn amphibole-bearing units weather irregularly to a pale-brown colour and are invariably altered to chloritic and biotitic material. Examples of these probable volcaniclastic 'green beds' are seen at NJ 29882245 and, adjacent to a 10-25 cm-thick lenticular metadolostone bed, at NJ 2994 2244. The upper parts of the formation are seen between NJ 29362263 and NJ 2958 2257; there, amphibolite units are interbedded with micaceous and feldspathic psammite, semipelite, minor quartzite and amphibole-bearing psammite. In one instance, exposures of a variably bluish to purplish grey, fine-grained, knobbly weathering amphibolite are seen. This amphibolite unit is several metres thick, apparently concordant, finely cleaved, and notably pyritic.

The transition up into the Kymah Quartzite Formation is marked by the incoming of thicker quartzite units, commonly with gritty bases. The boundary is faulted in the Kymah Burn section, but as the beds dip moderately to steeply to the east-south-east, probably only a small part of the succession is missing. The lowest exposures stratigraphically (at NJ 2942 2262) consist of blocky to massive, thick-bedded, gritty quartzites and feldspathic quartzites with thin pelitic interbeds and laminae. Grading and bottom structures show that the beds are inverted and young to the west. The succeeding lithologies are interbedded quartzites and 5-20 mthick units of grey-green to purplish grey amphibolite. Moreindurated, massive to blocky, cream to white quartzite beds, locally showing gritty bases, are present downstream.

Where the Dry Stripe enters the main gorge at NJ 2927 2268, a c. 10 m-thick, greenish grey metabasalt sheet passes laterally into a c. 4 m-wide dyke, which transects the quartzite beds adjacent to a small SE-trending fault. This intrusive sheet is massive, sparsely feldspar-phyric and is a member of a suite of early-Caledonian metadolerite intrusions (see Interpretation) 
The middle and higher parts of the Kymah Quartzite Formation are folded into a tight downward-facing antiform (where the beds young downwards). The white to cream quartzites are well bedded, locally gritty and show good cross-bedding and some grading. On the eastern limb of the antiform, the beds dip very steeply to the south-east and the change in dip that marks the antiformal hingezone corresponds with the change in burn orientation from northsouth to ESE-WNW at around NJ 2912 2312. Downstream, the beds first dip very steeply to the west and young eastwards, but west of The Eachrach they dip steeply eastwards and young westwards, i.e. they define a downward-facing synform (Figure 20b). The bedding is difficult to discern in these massive to blocky quartzites. Where the burn turns northwards, several amphibolitic beds are interbanded with the quartzites. At NJ 28822324 a several metrethick unit of purplish and greenish grey, pyritic amphibolite shows vesicular textures and pillow structures. Tuffaceous units are also present. In thin section these basic metavolcanic rocks consist of plagioclase feldspar, chlorite, hornblende, biotite, quartz, ilmenite, and titanite. Epidote is locally abundant in some units. Two fine but penetrative cleavages can be discerned in parts of the metavolcanic outcrops. The quartzite downstream dips steeply eastwards and shows cross-beds in parts. It is generally indurated and becomes hornfelsed with chlorite and pyrite veining adjacent to the microgranite intrusion.

The outcrop of the Kymah Quartzite Formation diminishes in width to the south-south-west where it lies in the core of the earlier tight syncline that is refolded by the later upright antiforms and synforms in the Kymah Burn section (Figure 20a, b). The Ladder Hills Formation and its lateral equivalent, the Nochty semipelite Formation, underlie most of the Ladder Hills area, where their $c$. 3-5 km-wide outcrop is a result of a similar refold structure to that defined by the main quartzite unit in the Kymah Burn section.

\subsection{Interpretation}

The distinctive stratigraphy of the Islay subgroup rocks in the Ladder Hills shows that a several kilometre-thick turbiditic sandsilt-mud succession developed locally in this area. The resultant Ladder Hills Formation and Nochty Semipelite Formation were probably deposited relatively rapidly from density currents in a small fault-bounded marine basin, accompanied by periodic basic volcanicity. Metadiamictite units and associated metadolostones occur within the Ladder Hills Formation farther south around NJ 242 177. The occurrence of thin metadolostones and tuffaceous units in the Kymah Burn section suggests that either diamictites were not deposited here, or that they were deposited and eroded prior to deposition of the overlying sediments. However, it is clear that the deposition and volcanicity here were coeval with the occurrence of shallow marine ice sheets elsewhere in Scotland and Ireland (see the Muckle Fergie Burn, Tempar Burn and Garvellach Isles GCR site reports).

The concordant and interbedded nature and pillow-lava features of several of the amphibolitic units show that they were originally 
deposited as sub-marine basaltic lavas. Unequivocal metavolcanic rocks occur in the uppermost parts of the Ladder Hills Formation and at the lower and middle levels of the Kymah Quartzite Formation. Tuffaceous units occur close to lavas in the Kymah Quartzite Formation and scattered through the Ladder Hills Formation. The metavolcanic rocks show two penetrative cleavages locally, suggesting that they have undergone the same structural history as the adjacent metasedimentary rocks. Other mafic units might represent subvolcanic basic sheets, but the thicker sheets with relict metadolerite textures were probably intruded during a later period of basic intrusion approximately coeval with the emplacement of the nearby Morven-Cabrach Pluton at C. $470 \mathrm{Ma}$ (Dempster et al., 2002). These early-Caledonian basic sheets and related dykes are very abundant on upper Donside around Corgarff and in the eastern part of the Ladder Hills.

The structure of the area can be readily interpreted as the product of two phases of ductile deformation. Two distinct penetrative cleavages are seen in pelitic and mafic lithologies and a later crenulation cleavage is present locally in the some of the pelitic units. The Kymah Quartzite Formation is little deformed internally, thus preserving original sedimentary features. However, the formation acted as a more-competent layer and has provided the focus for the large-scale refold structure. The quartzite was originally disposed in a tight, anticline-syncline fold-pair, overfolded to the north-west and with an axial plane dipping gently to moderately south-east. The mapping of bedding and way up, combined with limited cleavage observations, shows that upright tight folds have refolded this primary structure, with an antiform prominent in the Kymah Burn section. It is difficult to know whether the original basin architecture has had any control on the subsequent structural development, but such phenomena are common in more-recent basins subject to tectonic compression and inversion.

The rocks of the Kymah Burn and surrounding area do not preserve their full metamorphic history. Here, later retrogression to greenschist facies has altered many of the earlier amphibolitefacies assemblages in both the metasedimentary and meta-igneous rocks. In particular, the high-pressure kyanite assemblages recorded to the north and west from nearby Glen Fiddich and Glen Livet by Beddoe-Stephens (1990) are absent (see the Auchindoun Castle GCR site report). Additional, later fluid-related alteration is linked to the presence of NNE-trending faults and related breccia zones that are present in this area.

\section{4 Conclusions}

The Kymah Burn GCR site provides a spectacular cross-section through a large-scale refolded fold affecting the lowest units of the Argyll Group. By careful observation of bedding and cleavage orientations, combined with sedimentological way-up evidence, it is possible to recognize an early near-isoclinal syncline-anticline fold-pair whose axial plane originally dipped gently to the southeast. These NW-verging folds have been refolded by more-obvious 
tight upright folds, giving rise to a large-scale interference structure that is transected by the Kymah Burn.

The site is representative of three major formations and is a type section for one. The Ladder Hills Formation is a sequence of turbiditic psammites, semipelites and pelites over a kilometre thick that formed in a small local basin coeval with the deposition of tillites and related glacial deposits over a wider area of Scotland and Ireland. It includes minor metabasalt units with pillow structures, altered basic volcaniclastic units and thin lenticular metadolostone beds. Laterally it passes south-eastwards into the Nochty Semipelite and Limestone Formation. Both formations are overlain by the Kymah Quartzite Formation, marked by the incoming of thicker purer sands, typically showing crossbedding and gritty bases to the beds. Basaltic lavas and possible tuffaceous units are also recognized in this formation. Metadolerite sheets and rare dykes have also intruded the whole sequence during the Caledonian Orogeny. Although the beds have been metamorphosed to amphibolite facies, later retrogression has partly altered the original peak metamorphic mineral assemblages to greenschist facies.

The site is of national importance as it documents some unique stratigraphical variations in the Islay Subgroup, displays good evidence of basic volcanism coeval with the widespread midDalradian glaciation, and provides a valuable insight into the overall structure of this part of the North-east Grampian Highlands .

\section{BLACK WATER}

\section{(NJ 355 303-NJ 378 308)}

\section{Stephenson and D.J. Fettes}

\subsection{Introduction}

The lower part of the Black Water, a major tributary of the River Deveron in the Cabrach area, south-west of Huntly, provides a continuous section through the most-extensive sequence of metavolcanic rocks in the Dalradian of the North-east Grampian Highlands .

The metavolcanic rocks occur within a varied succession of gritty psammites and pelites of turbiditic character that crop out immediately to the east of the Portsoy Lineament (see 1.1 .3 in Introduction). Together, these metasedimentary and metavolcanic rocks form the Blackwater Formation. As with most stratigraphical units to the east of the Portsoy Lineament, direct correlation at formation level with Dalradian outcrops to the west and south is not possible (Fettes et al. 1991; Stephenson and Gould 1995). However, the rocks have lithological characteristics that are typical of the Argyll Group and pass upwards and south-eastwards into Southern Highland Group strata. This would seem to be consistent with a stratigraphical position near the top of the Argyll Group, probably equivalent to the Crinan and/or Tayvallich subgroups elsewhere. 
The lower part of the Blackwater Formation has been divided into three members, based upon the compositions of the metavolcanic rocks. In ascending stratigraphical order these are the Lynebain Basic Volcanic Member, the Kelman Hill Ultrabasic Volcanic Member and the Ardwell Bridge Basic Volcanic Member. The Lynebain and Ardwell Bridge members consist mainly of metabasaltic rocks, which locally exhibit complete or fragmental pillow structures. The Kelman Hill Member contains some metabasalts but is dominated by a variety of ultrabasic rocks (metapicrites), some of which are highly fragmented with a fine-grained hyaloclastite appearance. Above, the formation consists mainly of dark-grey pelites, graphitic in parts, with conspicuous andalusite schists and a number of persistent beds of gritty psammite (the Corinacy Pelite Member) .

The Blackwater Formation is poorly exposed over much of its outcrop but high-amplitude magnetic anomalies, mostly restricted to the part of the formation that is known to contain metavolcanic rocks, have greatly assisted in its mapping. Measurements of magnetic susceptibility on pelites from the Black Water section indicate that some of the anomalies result from high magnetite contents in metasedimentary rocks (Fettes et al., 1991). An igneous source for this magnetite seems likely and this strengthens the case for the meta-igneous rocks being penecontemporaneous with their host sediments in a volcanic setting. Magnetic evidence is unable to differentiate between the basic and ultrabasic types.

The first Geological Survey map of this area was published as oneinch Sheet 85 (Rothes, 1898), with an accompanying memoir (Hinxman and Grant Wilson, 1902). Mackie (1908) was the first to suggest that some of the basic meta-igneous rocks in the area had a volcanic origin and Dewey and Flett (1911) identified pillow lavas at this GCR site. The pillow structures were described in some detail by MacGregor and Roberts (1963), together with an account of their petrography and metamorphic history. A detailed resurvey, incorporating the results of ground magnetic traverses at $200 \mathrm{~m}$ spacing, was undertaken by the British Geological Survey and published as 1:50 000 Sheet 85E (Glenfiddich, 1996). This work was incorporated in a regional synthesis (Fettes et al., 1991) and formed the basis for a programme of geochemical sampling and drilling that targeted the igneous rocks as potential hosts of gold and platinum-group elements (Gunn et al., 1990). However, the mineral investigations were not encouraging, with uniformly low PGE (maxima 11 ppb Pt, 10 ppb Pd, 5 ppb Rh), only sporadic slight enrichment in gold (maximum 150 ppo Au) and no attendant enrichment in base metals or chalcophile elements. Mineralogical and geochemical aspects of the volcanic rocks have been described and discussed by Macdonald et al. (2005) and by Fettes et al. (2011), and there is a brief field guide to the eastern end of the section by Gillen (1987).

\subsection{Description}

The Blackwater Formation is bounded to the north-west throughout its outcrop by the Portsoy Shear-zone. In this area, the shearing is concentrated in a $1 \mathrm{~km}$-wide zone, in which lie many pods of 
sheared serpentinite and metagabbroic rocks between the larger Succoth-Brown Hill and Blackwater intrusions of the North-east Grampian Basic Suite (Fettes et al., 1991). To the south-east of the shear-zone, for a cross-strike width of at least $2 \mathrm{~km}$, and certainly extending across the entire outcrop width of the metavolcanic rocks, all lithologies have a single, possibly composite, planar fabric sub-parallel to the bedding. The whole sequence strikes north-east-south-west with a generalized steep dip to the south-east. No folds of any scale are seen, and instances where the fabric in pelitic beds is slightly oblique to bedding are rare.

The stream section that is the GCR site extends from the faulted contact of the Blackwater Formation with the sheared margin of the Blackwater Intrusion at NJ 355 303, downstream to Blackwater Bridge (NJ 378 308), which was formerly known as Ardwell Bridge (Figure 21). From this section, the outcrop of the metavolcanic rocks extends north-eastwards, averaging c. $2 \mathrm{~km}$ in width, for some $8 \mathrm{~km}$. To the south-west lava exposures become impersistent in poorly exposed ground and their magnetic anomalies cannot be traced for more than $5 \mathrm{~km}$.

The metavolcanic rocks are, for the most part, interbedded with gritty psammites and mica schists, locally with black, graphitic, schistose or phyllitic pelites. Some gritty psammites have been mapped out separately and commonly have distinctive blue-grey quartz clasts. A basal predominantly pelitic unit is present in places. Excellent graded units at the western end of the Black Water section (for example, at NJ $3596 \quad 3040$ and NJ 3621 3040) indicate younging to the south-east.

The metavolcanic units range from a few metres to $50 \mathrm{~m}$ in thickness and are concordent with the metasedimentary rocks. Contacts with the metasedimentary rocks are variable; in some cases these are relatively sharp, in others the metavolcanic rock is rather nodular with carbonate veining and in some cases the edge of the metavolcanic unit is brecciated with metasedimentary infilling. In excellent examples at NJ $3714 \quad 3058$ and NJ $3734 \quad 3087$ a metavolcanic unit has a carbonated nodular margin passing into a relatively massive centre, the opposite margin being brecciated with a metasedimentary matrix. This asymmetry is consistent with an origin as a lava, although it is not clear which margin marks the base and which the top. Vesiculation is common in all three members .

Metabasaltic pillows are well exposed near Blackwater Bridge, at NJ 37763083 and NJ 37513082 (MacGregor and Roberts, 1963). Fragmental pillows also occur in places and are particularly well developed in the River Deveron at Lynebain (NJ 412 351), some $7 \mathrm{~km}$ north-east of the Black Water section. The pillows at Blackwater Bridge are ellipsoidal, with horizontal cross-sections of some $60 \mathrm{x}$ $15 \mathrm{~cm}$ and vertical dimensions of up to $150 \mathrm{~cm}$. Small, originally spherical vesicles within the pillows show concentric banding in places and, rarely, elongate vesicles radiate around the noses of individual pillows. The pillows are bordered by fine-grained, nonvesicular selvedges and small volumes of altered basaltic material occur between the pillows. Both pillows and amygdales are flattened within the regional fabric, which is most strongly 
developed at the margins of and between the pillows. Interpretation of the pillow orientations is equivocal but better evidence from the metasedimentary rocks confirms that the Black Water section traverses a continuous south-east-younging sequence.

In terms of their whole-rock chemistry, the metavolcanic rocks range from ultrabasic (metapicrites) to basic (metabasalts and meta-basaltic andesites), with some intermediate compositions (meta-andesites) (Macdonald et al., 2005). As a result of amphibolite-facies regional metamorphism, they have mineral assemblages dominated by amphiboles.

The metabasalts and meta-andesites are mainly aphyric. They consist of aggregates of dark green clinoamphibole (actinolite to magnesiohornblende to pargasitic magnesiohastingsite in composition), with lesser amounts of plagioclase, quartz and ilmenite, the latter commonly rimmed or replaced by titanite. Aggregates of epidote and quartz could represent pseudomorphs after plagioclase phenocrysts. Distinctive pyroxene-phyric types crop out near Shenval (NJ 368 308) and have been found as float on Kelman Hill (NJ 396 334), some $3 \mathrm{~km}$ to the north-east. In these rocks, amphibole pseudomorphs after phenocrysts of original, igneous clinopyroxene contain rare relict cores of ferroan diopside.

The metapicrites are variable, ranging from massive to highly fragmented with sharp fine-grained shards, giving the appearance of a hyaloclastite. The more-massive forms consist almost entirely of felted intergrowths of colourless to pale green magnesian clinoamphibole (tremolite to magnesiohornblende in composition) with chlorite and sparse small rounded grains of chromian magnetite. Excellent examples of brecciated ultrabasic rocks are found as float to the east of Shenval. These consist of ultramafic clasts set in an ultramafic matrix (Figure 22). The fragments are of varying type, up to several centimetres in size and constitute 60-80\% of the rock; they are generally flattened into alignment with the regional fabric. The matrix to the fragments is highly sheared, streaky and chlorite rich. At the microscopic scale, so few original features are preserved that it is difficult to determine whether the rocks are of extrusive or intrusive origin. Some sections contain highly elongate grains of ilmenite, which might indicate rapid cooling and therefore a volcanic origin. In others a variolitic texture is preserved, while some of the fragments were originally glassy and now have a grain size less than 10 microns.

Overall, there is little doubt of the predominantly volcanic origin of most of the meta-igneous rocks, although some of the more-massive sheets could have been shallow, subvolcanic sills. An undoubtedly intrusive metabasaltic unit occurs near Torr of Shenwell (NJ 3746 3083), where a C. 20 m-thick sheet shows a sharp, non-vesiculated contact against psammites and andalusite schists. The intrusion is geochemically similar to extrusive rocks of the Ardwell Bridge Member and it is assumed that they were broadly coeval. The most evolved, and finest grained, rock occurs at the eastern margin of the intrusion and there is a gradational increase in grain size towards a metagabbroic central facies, which is less 
evolved. The intrusion seems, therefore, to have formed from a magma column that had become differentiated at greater depth.

The ENE-trending faults that are prominent on Figure 21 are part of a regional set, which has been particularly well delineated in this area by the ground magnetic survey (Fettes et al., 1991). The linear magnetic anomalies are clearly displaced, the inferred dislocations commonly coincide with topographical features and some are readily seen on air photographs. This is one of the youngest sets of regional faults, which elsewhere in the North-east Grampian Highlands are associated with late-Carboniferous quartz-dolerite dykes.

\subsection{Interpretation}

The geochemical studies of Macdonald et al. (2005) and Fettes et al. (2011) have shown that the Blackwater metavolcanic rocks as a whole are of tholeittic affinity and are broadly similar to metavolcanic rocks elsewhere in the Dalradian succession. Their inferred parental magmas were relatively Ti- and Fe-rich highmagnesia basalts with total iron oxides C. $14 \%$ and $\mathrm{MgO}$ C. $10 \%$ Fractionation of iron-titanium oxide minerals, olivine and clinopyroxene from the parental magmas generated a range of daughter magmas extending to tholeiitic andesite composition. Some of the more-evolved rocks show evidence of minor accumulation of iron-titanium oxides. A continuous enrichment in $\mathrm{Al}_{2} \mathrm{O}_{3}$ indicates that plagioclase fractionation must have been absent or muted, which is consistent with an absence of Eu anomalies in rare-earth patterns. Crystallization of plagioclase can be significantly delayed under conditions of high $P_{\mathrm{H} 20}$ and hence Macdonald et al. (2005) suggested that the Blackwater magmas might have been relatively hydrous. The picritic rocks formed by accumulation of olivine and minor chrome-spinel within the parental basalts, probably at deep crustal levels. Their high MgO content (over 18\% and ranging up to 35\%) had originally led to speculation that they might reflect primary, high-temperature (possibly komatiitic) magmas, which to some extent prompted the investigations for gold and platinum-group mineralization (Gunn et al., 1990; Fettes et al., 1991). However, this was not considered likely by Macdonald et al. (2005).

Concentrations of incompatible trace elements such as $\mathrm{Zr}$, Nb and $\mathrm{Y}$ suggest that the primary magmas of the Blackwater metavolcanic rocks were generated from a mantle source that was relatively enriched compared to a Mid-Ocean Ridge Basalt (MORB) source. This is a feature that they share with other late-Argyll Group metavolcanic rocks such as the Tayvallich lavas (Fettes et al., 2011). Other metavolcanic rocks, from lower in the Dalradian succession, have geochemical characteristics more typical of a depleted, MORB-like, mantle source (e.g. Goodman and Winchester, 1993). Hence Macdonald et al. (2005) and Fettes et al. (2011) have speculated that Dalradian metavolcanic rocks represent varying degrees of mixing of magmas from these two mantle sources.

It would appear that there was an overall trend in the Dalradian from basalts generated in more-depleted mantle sources, which were erupted earlier, to 'enriched' types, which were erupted later. 
The latter, including the Blackwater metavolcanic rocks, can be classed as Fe-Ti basalts, which are developed typically at propagating rifts that are progressively breaking through rigid lithosphere, and Macdonald et al. (2005) suggested that progressive rupturing along the margin of Laurentia, resulted in the moreenriched source rising to higher levels and tending to mix less with the depleted source.

The Blackwater metavolcanic rocks are interbedded with metasedimentary lithologies, characterized by coarse turbidites that originated as deep-water basin sediments. Together they record a crucial stage in the break-up of the supercontinent of Rodinia, as lithospheric thinning, crustal instability and continental rifting led into the formation of the Iapetus ocean during Argyll Group times (Fettes et al., 2011). The siting of this sub-marine volcanism, along the Portsoy Lineament, emphasises the importance of the lineament as a tectonothermal boundary and suggests that its origins might lie in the basin architecture that evolved as a result of the initial continental rupture (Ashcroft et al., 1984; Fettes et al., 1986).

\subsection{Conclusions}

The Black Water provides a continuous river section through the thickest and most extensive sequence of metavolcanic rocks in the Dalradian of the North-east Grampian Highlands. The presence of metabasaltic pillow lavas in this section has long been known but even more remarkable are the wide range of fragmented highmagnesium ultrabasic lavas (metapicrites) that originated by the accumulation of olivine from the basaltic magmas in deep-crustal magma chambers. The formation of pillows and the fragmentation of the metapicrites are the results of sub-marine eruption in deep unstable basins, characterized by turbibitic sedimentation.

The Blackwater metavolcanic rocks, together with the nearcontemporaneous Tayvallich lavas in the South-west Grampian Highlands, are typical chemically of volcanic rocks in propagating rift basins, and provide vital information about the tectonomagmatic conditions that resulted from the break-up of Rodinia and the initial formation of the Iapetus ocean, some 600 million years ago. The basin in which the Blackwater rocks were erupted might have been related in some way to the initial formation and location of the Portsoy Lineament, which was to influence sedimentation, magmatism and tectonics for the following 140 million years or more.

\section{AUCHINDOUN CASTLE (NJ 345 368-NJ 362 375)}

\section{Stephenson}

\subsection{Introduction}

The ruins of Auchindoun Castle stand on a knoll of metalimestone above the River Fiddich, $3.5 \mathrm{~km}$ south-east of Dufftown. Exposures 
below the castle, in the river banks, are of dark graphitic pelite of the Mortlach Graphitic Schist Formation, and it is the regional metamorphic minerals in the pelite that are the main feature of interest at this GCR site. Square cross-sections of chiastolite (a variety of andalusite), clearly seen in hand specimen, are seen in thin section to have been replaced by kyanite, indicating a significant increase in regional pressure. The metalimestone is the Dufftown Limestone Member at the base of the Mortlach Formation, which in this area marks the base of the Ballachulish Subgroup.

The primary survey of the area was published as one-inch sheet 85 (Rothes) in 1898, together with a brief memoir (Hinxman and Grant Wilson, 1902). The area was not revisited until it was remapped by the British Geological Survey for 1:50 000 Sheet 85E (Glenfiddich, 1996), which was when the interesting relationships between the regional metamorphic minerals were discovered. This led to a detailed investigation of the pressure-temperature conditions of metamorphism by Beddoe-Stephens (1990) that formed part of a wider study of metamorphic conditions on either side of the PortsoyDuchray Hill Lineament. The rocks at Auchindoun lie on the west side of the lineament, where peak pressures were up to 4 kbar higher than they were immediately to the east of the lineament, due to near-isothermal compression beneath westerly directed thrusting along the line of the Portsoy-Duchray Hill Lineament/Shear-zone. Samples from this locality were also used in a regional geochemical study of Dalradian metacarbonate rocks, which proved to be of significant value in stratigraphical correlation (Thomas, 1989), and calcsilicate beds within the pelites provided material for a study of amphibole geochemistry that revealed implications for the original depositional environment (Stephenson, 1993).

\subsection{Description}

The area around Auchindoun lies on the south-eastern limb of the Ardonald Anticline, a NW-verging, tight, regional-scale fold of possible D3 age. The right-way-up succession extends from the Pitlurg Calcareous Flag Formation of the Lochaber Subgroup, here poorly exposed, through the Mortlach Graphitic Schist Formation, to the Corriehabbie Quartzite Formation of the Ballachulish Subgroup, which forms a continuous ridge to the south-east of Glen Fiddich (Figure 23). Bedding dips to the south-east at between $30^{\circ}$ and $65^{\circ}$ and the dominant cleavage in the pelites (?S2) commonly dips at a lower angle, indicating local inversions possibly due to intermediate-scale folds.

The Dufftown Limestone Member in this area is of variable thickness, up to about $3 \mathrm{~m}$, but at Auchindoun Castle the outcrop is thickened by a series of tight, sSW-plunging folds. The member is composed typically of banded, grey, crystalline metalimestone, but in places thin beds of metalimestone and pinkish brown-weathering calcsilicate rock are interbedded with phyllitic pelites. At the castle, thin pelitic partings in the metalimestone have a strong spaced cleavage (?S2) as is seen in the overlying pelites. Southwest of the castle the metalimestone outcrop is terminated by a fault. 
The main part of the Mortlach Graphitic Schist Formation, above the Dufftown Limestone Member, is well exposed in the banks of the River Fiddich and in tributaries on the south-east side of Glen Fiddich, in particular the Allt a' Choileachain, the Red Burn and the small Burn, where the outcrop width is greatly increased by tight folding. In this area, it is composed predominantly of darkgrey, fine-grained, finely banded pelite. Banding takes the form of thin, 1-5 mm-wide bands of pale semipelite or psammite, which enable the orientation of the original bedding to be seen in most exposures. The pelites are usually hard and blocky, but are phyllitic to schistose in places, with a strong S2 spaced/crenulation cleavage. Where the dominant cleavage is near coincident with the bedding, the rock becomes very hard and slaty. Such slates have been quarried at several places on the hill slopes to the east (e.g. at NJ 358370 and NJ 375 386). In most exposures the pelites contain prominent, square-sectioned chiastolite and many are garnetiferous. Most are graphitic and some are quite pyritiferous. Bands and pods of tremolitic amphibole, with or without subsidiary carbonate-rich laminae, within the pelites have been interpreted as para-amphibolites and indicate a continuation of the calcareous facies above the basal metalimestone member (Stephenson, 1993).

Throughout the exposures of pelitic rocks, there is good evidence in thin section of replacement of chiastolite by kyanite in what appears to be a direct pseudomorph relationship. Squarish to rectangular porphyroblasts of chiastolite with preserved inclusion 'crosses' of graphite have been replaced by radial fan-like sheaves of kyanite (Figure 24), which commonly show varying degrees of later replacement by muscovite. A fine-grained crenulated micaceous fabric can be seen to post-date the chiastolite and slight strain effects in the kyanite suggest that this fabric might also post-date kyanite growth. Other regional metamorphic minerals present are garnet and biotite.

\subsection{Interpretation}

It has long been recognized that metamorphism in the Buchan region, to the east of the Portsoy-Duchray Hill Lineament, is distinct from that elsewhere in the Grampian Terrane, being characterized by relatively low-pressure/high-temperature mineral assemblages (see 1.3 in Introduction). The western limit of this low-pressure metamorphism is broadly coincident with the shear-zones that define the Portsoy-Duchray Hill Lineament and also mark the western margin of the structurally and stratigraphically distinct 'Buchan Block' (Baker, 1985; Fettes et al., 1986; Harte and Dempster, 1987). To the west of the lineament, lower structural levels and older Dalradian rocks are exposed and the metamorphic mineral assemblages are characteristic of a higher pressure.

The low- and high-pressure assemblages are characterized essentially by andalusite and kyanite respectively, and D.J. Fettes (on the BGS 1:250 000 Sheet 57N 04W, Moray-Buchan, 1977) and Chinner and Heseltine (1979) each plotted andalusite-kyanite isograds, parallel and close to the Portsoy-Duchray Hill Lineament. However, there is a well-defined zone, up to $10 \mathrm{~km}$ wide on the 
western side of the lineament, where original andalusite has inverted to kyanite indicating a pressure increase after the initial metamorphism (Chinner and Heseltine, 1979; Baker, 1985). On the Banffshire coast, this zone is narrow but is beautifully illustrated in the well-known chiastolite-bearing pelites at the swimming pool west of Portsoy (see the Cullen to Troup Head GCR site report). There, the chiastolite is clearly seen in thin section to be pseudomorphed by kyanite and muscovite, but the relationships are complicated by the presence of sillimanite, which pre-dates the kyanite, and by later overgrowths of kyanite and muscovite that post-date the main fabric. Inland, and especially in the area around Auchindoun Castle, there is a much simpler replacement of the original chiastolite porphyroblasts.

The regional study of Beddoe-Stephens (1990) placed quantitative pressure and temperature constraints on the observed metamorphic reactions on both sides of the Portsoy-Duchray Hill Lineament. values were calculated from various thermodynamic calibrations based upon reactions between commonly occurring minerals. Both thermal and barometric 'breaks' are clearly seen at the lineament. East of the lineament, where only andalusite and sillimanite occur, pressures never exceeded $4.5 \mathrm{kbar}$ and temperatures of up to $660^{\circ} \mathrm{C}$ are recorded. West of the lineament, where kyanite occurs either as the sole aluminosilicate phase or as a replacement of andalusite, pressures of 7.5 to 8.5 kbar are recorded close to the lineament and these increase to over 9 kbar farther west. There is also a corresponding temperature increase from $500^{\circ} \mathrm{C}$ to $600^{\circ} \mathrm{C}$ westwards from the lineament. A sample from close to Auchindoun Castle, some $4.5 \mathrm{~km}$ to the north-west of the Portsoy-Duchray Hill Lineament, gave values of $8.5 \mathrm{kbar}$ and $605^{\circ} \mathrm{C}$. Compositional zoning in garnet crystals enables the pressure-temperature path that the rock has experienced during the growth of the garnet to be modelled. Using this method, samples from immediately west of the lineament have shown an increase in pressure of about 2 kbar, associated with only minor heating, which was sufficient to account for the observed inversion of andalusite to kyanite.

From detailed studies such as that of Beddoe-Stephens (1990), associated with previous work based largely on the coastal sections (e.g. Harte and Hudson, 1979; Hudson, 1985; Baker, 1987), it has been possible to deduce a sequence of structural and metamorphic events to account for all of the features described above. The development of andalusite, characteristic of high-temperature, lowpressure metamorphism, clearly extended westwards from the Buchan area, across the position of the Portsoy-Duchray Hill Lineament as is shown by the relics of andalusite, for example in the Auchindoun area. The andalusite-kyanite isograd of Chinner and Heseltine (1979) marks the western limit of this original andalusite, which might have developed at least in part in response to high heatflow associated with the emplacement of basic magma in the Buchan Block at around $470 \mathrm{Ma}$.

Subsequent to the development of andalusite, the rocks immediately to the west of the lineament underwent a pressure increase of up to 2 kbar that transformed the andalusite to kyanite and it is these peak metamorphic conditions that are recorded by the calculated pressure and temperature values of Beddoe-Stephens (1990). 
Ashcroft et al. (1984) suggested that it was subvertical shear movements along the Portsoy-Duchray Hill Lineament after the emplacement of the basic magmas, with relative uplift to the west, that brought up the higher grade rocks. However, Baker (1987) and Beddoe-Stephens (1990) refined this to suggest that westerly or north-westerly directed thrusting across the lineament emplaced a thick upper Dalradian sequence of the Buchan Block above older rocks to the west, which were hence subjected to increased overburden pressure and near-isothermal compression. Although this explanation has been generally accepted, there is little stratigraphical evidence for overthrusting and the Dalradian stratigraphy seems to young consistently from west to east across the Portsoy-Duchray Hill Lineament with no repetition (Fettes et al., 1991). Hence Dempster et al. (1995) have offered the alternative suggestion that the pressure increase was due to magmatic loading caused by emplacement of the basic magmas.

The present steep attitude of the shear-zones along the PortsoyDuchray Hill Lineament is probably attributable to subsequent late folding and crustal warping, during D3 and later events, resulting in exhumation of strata from deeper levels on the western side. This uplift must have been relatively rapid in order to have preserved the mineral relationships without further retrograde reactions taking place, and this is nowhere more true than at Auchindoun Castle.

\subsection{Conclusions}

Metamudstones (pelites) in the banks of the River Fiddich, below Auchindoun Castle, contain prominent minerals that provide a fascinating insight into the history of deformation and regional metamorphism in Dalradian rocks of the North-east Grampian Highlands. Rectangular white cross-sections are easily visible in hand specimen. Some have a dark 'cross' due to inclusions of graphite and their overall appearance is characteristic of chiastolite (a variety of the aluminium silicate, andalusite). However, thin sections reveal that the original andalusite has been replaced by kyanite, identical in composition to andalusite but stable under higher pressure conditions. These are exceptionally clear examples of a feature that has great significance in the understanding of metamorphic terranes and hence could be said to have international importance.

Detailed mineralogical studies have enabled the temperature and pressure at the peak of metamorphism to be calculated and, when combined with similar determinations throughout the region, these data reveal significant differences in metamorphic history between rocks on either side of the $\mathrm{N}$-S-trending Portsoy-Duchray Hill Lineament. It has been suggested that this is due to a considerable thickness of low-pressure-high-temperature rocks from the Buchan Block in the east having been overthrust westwards, increasing the overburden pressure on the rocks below and hence causing the low-pressure andalusite to recrystallize as the highpressure form of aluminium silicate, kyanite. 


\section{CULLEN TO TROUP HEAD \\ (NJ 511 673-NJ 828 669)}

\section{Stephenson, J.R. Mendum and D. Gould}

\subsection{Introduction}

This very large GCR site extends for $32 \mathrm{~km}$ along the north coast of the North-east Grampian Highlands from Cullen Harbour in the west to Troup Head in the east. Apart from a $1 \mathrm{~km}$-wide outcrop of Caledonian igneous rocks at Portsoy and a 2 km-wide outcrop of Devonian sedimentary rocks at Gardenstown, the bedrock is entirely Dalradian (Figure 25). It comprises a near-complete succession from the Cullen Quartzite Formation at the top of the Grampian Group to the highest parts of the Macduff Formation of the Southern Highland Group, although the Portsoy-Duchray Hill Lineament forms a major stratigraphical, structural and metamorphic break in the middle of the section (see 1.2.1 in Introduction). Exposure is generally excellent, notably in the intertidal zone, in marked contrast to the drift-covered inland areas where it is largely confined to generally poor stream sections. The coast therefore provides an invaluable and unique type section for the Dalradian succession that can be compared and contrasted with that of the Central Grampian Highlands. To the west of the Portsoy-Duchray Hill Lineament, many elements of the stratigraphy are common to both successions, and correlations are possible to subgroup and in some cases to formation level. However, east of the lineament correlations, even at subgroup level, are more tenuous.

The strata young overall from west to east, with only minor local reversals. To the west of the Portsoy-Duchray Hill Lineament, structures are comparable to those of the Central Grampian Highlands and are dominated by tight NW-verging folds. Here, there is no high-strain zone comparable to the Boundary slide at the Grampian-Appin group boundary, but shear-zones do occur at higher stratigraphical levels. The lowest, stratigraphically and structurally, is the Keith Shear-zone, which encloses pods of 600 Ma granite and whose trace intersects the coast just west of Portsoy. Deformation increases dramatically eastwards towards the Portsoy-Duchray Hill Lineament, with most structures becoming largely coplanar and colinear. The wide shear-zone that here marks the lineament contains variably deformed mafic and ultramafic intrusive igneous rocks of the 470 Ma North-east Grampian Basic Suite. East of the lineament, in the so-called 'Buchan Block', the rocks show small- and medium-scale folding, in parts with interference patterns, but the regional outcrop pattern is dominated by the broad, open Turriff Syncline, whose axis plunges gently to the north-north-east.

The coast section also provides a continuous section across the low-pressure regional metamorphic Buchan zones that characterize this part of the North-east Grampian Highlands (Stephenson et al., 2013a, fig. 12). The overall grade of metamorphism increases from low greenschist facies (biotite zone) in the centre of the Turriff syncline in the east, to upper amphibolite facies (sillimanite-k 
feldspar zone) adjacent to the Portsoy Lineament farther west. Immediately to the west of the lineament the Buchan mineral assemblages have been overprinted by higher pressure metamorphism of Barrovian type (lower amphibolite facies; kyanite zone), and there is evidence that pressures increased to the west.

The area was first mapped for the Geological Survey by J. Horne, and one-inch sheet 96 (Banff) was published in 1895. The area was subsequently remapped in greater detail by $\mathrm{H} . \mathrm{H}$. Read who published the first full account of the district (Read, 1923) together with a revised one-inch map (also published in 1923). Read's work established the lithostratigraphy of the coast section and led to numerous important publications on the magmatism, structure and metamorphism of the region (Read, 1919, 1936, 1955; Read and Farquhar, 1956). These in turn prompted and inspired other investigations, such that this coast section became one of the most intensively studied parts of the whole Dalradian outcrop. It has certainly been studied by the greatest number and variety of workers. The sedimentation was studied by Sutton and Watson (1955) and Loudon (1963), but most of the subsequent investigations concentrated upon the structure and metamorphism (Sutton and Watson, 1956; Johnson and Stewart, 1960; Johnson, 1962; Loudon, 1963; Fettes, 1970, 1971; Treagus and Roberts, 1981; Moig, 1986). Several papers have concentrated upon the position and nature of the western margin of the Buchan Block and its relationship to the 'main' part of the Grampian Terrane (Elles, 1931; Sturt et al., 1977; Ramsay and Sturt, 1979) leading to speculation on the nature and significance of the Portsoy-Duchray Hill Lineament (Ashcroft et al., 1984; Fettes et al., 1986, 1991). More-detailed studies of the metamorphism have been undertaken by a number of workers (Chinner, 1966; Ashworth, 1975, 1976; Hudson, 1980, 1985; Hudson and Harte, 1985; Baker, 1985, 1987; Beddoe-Stephens, 1990; Dempster et al., 1995). The presence of glacigenic boulder beds at two separate stratigraphical levels has generated much interest and discussion on the age of the succession (Sutton and Watson, 1954; Spencer and Pitcher, 1968; Hambrey and Waddams, 1981; Stoker et al., 1999) but the palaeontological studies of the higher parts of the succession are now viewed as inconclusive (Skevington, 1971; Downie et al., 1971; Bliss, 1977; Downie, 1984; Molyneux, 1998). The area has been remapped by the British Geological Survey, resulting in the publication of two 1:50 000 sheets, 96W (Portsoy, 2002) and 96E (Banff, 2002). As part of this remapping programme, samples from the coast section contributed to a regional geochemical study of metacarbonate rocks that proved to be of value in stratigraphical correlation (Thomas, 1989).

Much of the coastline is relatively easily accessible and it is very popular with field parties. Excursions have been described by Read (1960) and by C. Gillen, N.H. Trewin and N.F.C. Hudson (in Trewin et al., 1987).

\subsection{Description}

The coastal section is described here from west to east, moving up the stratigraphical succession to originally higher structural 
levels and correspondingly lower metamorphic grades (Figures 25, 26).

\subsubsection{Grampian Group: Cullen Quartzite Formation}

The GCR site includes only the upper three members of the cullen Quartzite Formation, the lowest, the Findochty Quartzite Member is exposed between Buckie and the western side of Cullen Bay.

The section from Cullen Harbour (NJ 5110 6733) to Logie Head (NJ 5310 6810) exposes the upper $1000 \mathrm{~m}$ of the Logie Head Quartzite Member, some $70 \%$ of its total thickness. The strata are overturned, and dip at between $55^{\circ}$ and $90^{\circ}$ to the north-west; apparently shallower dips are mostly due to landslips. They are largely psammites with thin pelitic and semipelitic interbeds. Planar-laminated beds with flat bases, generally less than $0.5 \mathrm{~m}$ thick, together with tabular cross-bedded units, are characteristic. Some psammite units show aligned mud clasts and a poorly defined wispy lamination. Fold axes of prominent slump folds imply an original palaeoslope towards the north-north-west. At the western side of Portlong Hythe (NJ 5215 6765), some $70 \mathrm{~m}$ of pale-brown thicker bedded quartzites are present, but along its eastern side psammites are interbedded with semipelite beds ranging from a few centimetres up to $7 \mathrm{~m}$ thick. Pale-green garnetclinozoisite-bearing calcsilicate pods and lenses are developed locally (e.g. at NJ 5254 6770). Thick lenticular quartzite and psammite beds form the western and eastern promontories of Logie Head, separated by thinly bedded micaceous and feldspathic psammites and semipelites with calcsilicate lenticles.

The Dicky Hare Semipelite Member, c. $200 \mathrm{~m}$ thick, is exposed on the foreshore east of Logie Head from NJ 53106810 to NJ 53256755. It consists of thinly bedded, flaggy micaceous and feldpathic psammites, and garnetiferous semipelites and pelites with scattered calcsilicate lenses and rare centimetre-thick garnet-rich bands. In the upper part of the member, sedimentary structures include fine-scale and ripple-drift cross-bedding, flame structures and slump structures. Minor and medium-scale, close to tight and rarely isoclinal tectonic folds are also abundant in the mixed lithologies. The folds are generally asymmetrical with a $z-$ profile, and their axes mainly plunge gently to the south-west. In parts a folded lineation (L1) is seen and in the more-pelitic units a penetrative crenulation cleavage (S3) is developed. Read (1923) considered this unit to be a faulted repetition of the lowest part of the West Sands Member of the succeeding Findlater Flag Formation. The contact with the overlying sunnyside Psammite Member is defined by a strike-fault, marked by several metres of shattered rock, but this does not result in any significant repetition of the near-vertical strata.

The Sunnyside Psammite Member, some 500 m-thick, consists of typically grey to fawn, planar bedded quartzite and psammite, with tabular cross-bedding seen in parts. Individual beds are normally less than $1 \mathrm{~m}$ thick and semipelitic interbeds are present near the top of the member. Open to tight folding (F3 and F1) is present, particularly in its lower part. 


\subsubsection{Appin Group: Lochaber Subgroup: Findlater Flag Formation}

The Findlater Flag Formation consists of grey to brown, planar, thin-bedded to laminated, micaceous and feldspathic psammites with some thin, schistose, locally garnetiferous semipelite units. Flaggy partings rarely exceed $15 \mathrm{~cm}$ in thickness. They strike north-east, generally dip steeply south-east and show few outward signs of early large-scale fold structures. However, in parts minor folds with axial planes roughly parallel to bedding and gently NNE- or SSW-plunging axes are developed. The psammitic beds are not conspicuously deformed, but the more-pelitic lithologies have a well-developed schistosity commonly at a low angle to bedding .

Two members are recognized within the formation, which is otherwise undivided. The basal West Sands Mica Schist Member is about $125 \mathrm{~m}$ thick and consists of dark-grey to green-grey schistose garnetiferous semipelites, with psammitic ribs up to $1 \mathrm{~cm}$ thick. The bedding and well-developed schistosity are both subvertical, but centimetre-scale minor folds have axes that plunge gently to the south. The c. 7.5 m-thick Findlater Castle quartzite Member forms the spine of a conspicuous promontory, topped by the ruins of Findlater Castle at NJ 5418 6720. The white to fawn quartzite is thickly bedded and steep bedding surfaces show conspicuous largescale ripple marking (Figure 27). Cross-bedding is visible on clean-washed exposures at the base of the promontory. At low water the quartzite can be traced into the bay to the east where it is tightly folded.

\subsubsection{Cairnfield Calcareous Flag Formation}

This formation consists mainly of micaceous psammite and semipelite but is characterized by the presence of calcsilicate- and carbonate-bearing units. Most lithologies contain amphibole in the compositional range tremolite-magnesio-hornblende but its mode of occurrence varies (Stephenson, 1993). The dominant flaggy, finely bedded calcareous psammites and semipelites, range in colour from striped dark-grey and cream to pale-green and bluish grey. Amphibole in these beds is mainly fine grained and disseminated but some of the more-schistose lithologies contain radiating coarsegrained aggregates (c.f. 'garbenschiefer'). The beds strike northnorth-east and dip very steeply to the east-south-east. Smallscale tight folding is common locally and fold interference patterns are seen in places. Fold axes typically plunge gently to the north-north-east or south-south-west.

In the coast section, two distinctive members can be recognized. The lower, Crathie Point Calcsilicate Member consists of about 300 $m$ of predominantly pale-fawn and grey calcsilicate-bearing rocks with beds of impure cream metacarbonate rock, possibly dolomitic; the latter weather typically with a pale brownish and honeycombed surface. Some $250 \mathrm{~m}$ south of Crathie Point (around NJ 5490 6716), thin bands of gneissose muscovite-biotite semipelite contain kyanite and staurolite, indicative of lower amphibolite-facies metamorphism. This lithology can be correlated southwards as far 
as Glenlivet and the Cairngorm Pluton (see the Bridge of Brown GCR site report). The upper, Garron Point Tremolitic Flag Member consists of about $350 \mathrm{~m}$ of generally dark-grey, thin-bedded, flaggy muscovitic psammite and semipelite with abundant disseminated amphibole. Thin beds of dark green amphibole-rich rock (paraamphibolite) are characteristic and thin beds or lenses of impure metacarbonate rock occur rarely.

\subsubsection{Ballachulish Subgroup: Mortlach Graphitic Schist Formation}

About $250 \mathrm{~m}$ east of Garron Point (at NJ 5565 6685), rocks of the Garron Point Member are stratigraphically overlain by black, pyritic, highly graphitic pelite interbedded with metalimestone. These lithologies pass upwards at Sandend Harbour into grey calcareous psammite and semipelite with subsidiary graphitic pelite and metalimestone units. These lithologies constitute the Sandend Harbour Limestone Member, the basal unit of the Mortlach Graphitic Schist Formation. The beds of white to pale-grey coarsely crystalline metalimestone are up to several metres thick. They are prominent among the intertidal exposures on account of their creamy yellow weathering and well-developed banding, with many pelitic partings. Some are finely laminated and it has been suggested that they might be stromatolitic. Thin beds rich in amphibole, similar to those in the Garron Point Member, are also present in places. Abundant tight to isoclinal minor folds plunge at low angles to the north-north-east.

The main part of the Mortlach Graphitic Schist Formation lies beneath the beach and dune sands of Sandend Bay. It has been proved by a series of BGS boreholes (1992) to be c. $325 \mathrm{~m}$ thick and to be composed of dark-grey, graphitic, schistose to slaty pelite, with pale-grey kyanite porphyroblasts abundant in places. The boreholes found no trace of an overlying quartzite, the Corriehabbie Quartzite, one of the most persistent markers in the Appin Group of the Central and North-east Grampian Highlands. However, the quartzite does crop out inland, some $10 \mathrm{~km}$ to the south-west of Sandend Bay.

\subsubsection{Tarnash Phyllite and Limestone Formation}

A disused and flooded quarry behind the dunes of Sandend Bay at NJ 55786595 exposes centimetre-scale, banded, flaggy, pale-grey metalimestone with phyllitic semipelite partings and some thin beds of micaceous psammite. This is the Linkbrae Limestone Member that occurs at the base of the Tarnash Phyllite and Limestone Formation. Its lower contact was penetrated in a BGS borehole, in which the Mortlach Graphitic Schists pass upwards into banded greenish grey psammites and semipelites, which are calcareous in parts. The remainder of the formation (the major part) that consists of grey schistose to phyllitic semipelite, is very poorly exposed ephemerally on the beach at Sandend. 


\subsubsection{Blair Atholl Subgroup: Fordyce Limestone Formation}

Exposures on the east side of Sandend Bay are of blocky to massive, thin- to thick-banded, generally blueish grey crystalline metalimestones with subsidiary interbedded phyllitic to schistose pelites and semipelites. Cherty lenses and calcite veining are common. In contrast to the exposures on the west side of the bay, the axes of the numerous tight minor folds here plunge steeply (45$60^{\circ}$ ) to the east-north-east. Fold interference patterns are seen in parts. The metalimestones are overlain unconformably by old Red Sandstone breccia and sandstone.

\subsubsection{Argyll Group: Islay Subgroup: Arnbath Psammite Formation}

The upper part of the Fordyce Limestone Formation is cut out by a NW-trending fault that passes through Red Haven (NJ 5640 6630). To the north-east of this fault, and beyond a complex zone of shearing, most of the headland that terminates in Redhythe Point (NJ 5760 6715) is composed of quartzites, micaceous and feldspathic psammites and minor semipelites that constitute the Arnbath Psammite Formation. Calcsilicate pods are locally abundant. Small shear-zones are developed and the quartzite beds are commonly boudinaged giving a complex structurally disharmonic appearance to the rocks. Close upright $F 3$ folds that plunge southwards at 30 to $45^{\circ}$ are prominent in the cliff exposures, which are composed dominantly of thinly banded and laminated grey quartzites of the basal Redhythe Quartzite Member. The upper parts of the formation crop out inland and are very poorly exposed. However, on the north-west flank of Durn Hill (at NJ 567 642), some $2 \mathrm{~km}$ from the coast, numerous blocks of metadiamictite in field walls, almost certainly derived from the upper parts of this formation, have been interpreted as tillites (Spencer and Pitcher, 1968).

From about $300 \mathrm{~m}$ south-east of Redhythe Point, at NJ 5765 6695, the strata dip steeply and consistently to the south-east and display a strong bedding-parallel fabric; fold axes plunge more steeply $\left(45\right.$ to $\left.70^{\circ}\right)$ to the south-east and east-south-east. At the inlet of Foul Hole (NJ 5775 6675) there is a sharp contact of quartzites with gneissose and locally migmatitic psammites and semipelites, which is interpreted as the position of the Keith Shear-zone. About $1500 \mathrm{~m}$ south of here, at Boggierow Quarry (NJ 5747 6516), a highly foliated and xenolithic pale- to mid-grey muscovite-biotite granite, the Portsoy Granite, is inferred to mark the position of the shear-zone. U-Pb dating of zircons from the granite has given an emplacement age of $599.9 \pm 2.5 \mathrm{Ma}$ (Barreiro, 1998). Farther east, at NJ 5780 6679, folded migmatitic and gneissose psammites, semipelites and quartzites are cross-cut by a 12 m-thick amphibolite body with foliated margins, which is crosscut in turn by a c. 60 cm-wide irregular sheet of foliated muscovite-biotite granite. 


\subsubsection{Durn Hill Quartzite Formation}

East of Foul Hole, in a rocky semicircular bay at NJ 5790 6659, a fault divides amphibolite to the west from micaceous psammites overlain by c. $13 \mathrm{~m}$ of finely banded cream and grey metalimestones and metadolostones. Amphibolite lenses and pods are common and a 2.2 m-wide talc-magnesite pod occurs at the base. The metacarbonate rocks are succeeded by thick-bedded quartzites that contain a few quartz and granite pebbles, and pass up into poorly bedded, blocky to massive quartzites with subsidiary siliceous and micaceous psammites. The 'beds' dip steeply eastwards but are characterized by a strong foliation and steep down-dip lineation. Although traces of tight to isoclinal folds with steeply plunging axes can be distinguished in parts, in other areas the quartzites are rodded to form mullions. Deformation features dominate here and the lithologies are not typical of the Durn Hill Quartzite as seen inland.

\subsubsection{Easdale Subgroup: Castle Point Pelite Formation}

At St John's Well, the rapid transition from the Durn Hill Quartzite into the Castle Point Pelite Formation is well exposed on the foreshore. Graphitic pelite and semipelite are dominant at the base but pass eastwards into mid- to dark-grey, schistose, partly graphitic semipelite and pelite with minor thin beds of micaceous psammite. Calcsilicate pods and metacarbonate beds are present but only become abundant near the top of the formation at the outdoor swimming pool west of Portsoy. The formation typically shows abundant small-scale chevron-style folding and crenulation cleavages, but in its upper part close to tight, small- to mediumscale folding is well seen. Fold axis orientations are variable with refold patterns present. The rocks contain kyanite locally, both as blades and as pseudomorphs of chiastolite (andalusite); notable examples can be seen in the uppermost part of the formation at NJ 5846 6638. Staurolite is also present in parts and sillimanite has been recorded from muscovite-bearing pelites at Sandy Pots (NJ 58446654 ).

\subsubsection{Portsoy Limestone Formation}

The Portsoy Limestone Formation encompasses all of the metasedimentary rocks within the Portsoy Shear-zone on the coast section. It cannot be traced inland where thick superficial deposits mantle the bedrock, but many of its elements are certainly lenticular and its lateral continuity southwards is questionable. The variable lithologies are tightly folded and generally very strongly deformed, in parts having almost mylonitic fabrics.

The basal part of the formation, well exposed at Legg Moon (NJ 5851 6645), consists of tight to isoclinally folded pale to dark and bluish grey metalimestones with thin pelitic laminae. These thick metalimestones mark the transitional change up into morevaried lithologies. Semipelites and quartzites succeeding the metalimestones are intruded by gabbros and a large serpentinized 
lherzolite or harzburgite body, known locally as the 'Portsoy Marble'. This is succeeded eastwards by graphitic pelite, quartzite, semipelite and micaceous psammite. Pebbly and gritty quartzites show strong rodding and folding about steep, commonly near-vertical axes on a distinctive promontory at NJ 58646632 (Figure 28); they are succeeded by tightly folded and refolded metadolostones, graphitic pelite and psammite, and white to palegrey, tight folded metalimestone. The metalimestone also contains small veins of sphalerite, pyrite and chalcopyrite.

\subsubsection{Intrusive igneous rocks of Portsoy}

The metasedimentary rock outcrop is terminated against a vertical pod of anorthosite and to the east, beneath the town of Portsoy, variably deformed and amphibolitized ultrabmafic and mafic intrusive rocks, cut by sheets and pegmatitic veins of granite, dominate an across-strike section of $750 \mathrm{~m}$. However, substantial screens and rafts of metasedimentary rocks are present in the old Harbour area. The mafic and ultramafic rocks are interpreted as being truncated against a major fault on the eastern side of Links Bay, which probably coincides with a steep shear-zone on the eastern edge of the Portsoy Lineament. Almost all of the intrusive rocks have been shown by U-Pb zircon dating to have been emplaced at c. $470 \mathrm{Ma}$. Their complex field relationships and wider age constraints imply that emplacement was coeval with thrusting and penetrative deformation.

\subsubsection{Crinan Subgroup: Cowhythe Psammite Formation}

The majority of this formation consists of micaceous and feldspathic psammite with subsidiary biotitic semipelite and some minor calcareous units, notably the distinctive Rosehall croft Limestone and calcareous semipelites on Cowhythe Head. At the western edge of the outcrop, on the east side of Links Bay, are tightly folded calcsilicate rocks, metalimestones and semipelites with lenticular quartzite and psammites bodies. Although those beds are shown as part of the Cowhythe Psammite Formation on the BGS 1:50 000 Sheet 96W (Portsoy, 2002), some authors have attributed them to the Portsoy Limestone Formation.

The rocks have been metamorphosed to sillimanite grade and migmatization is variably developed, with the more-migmatitic units found in the western part of the outcrop. The first coherent unit of sheared and migmatitic semipelite that marks the eastern extent of the mixed calcareous rocks at Links Bay has been interpreted as marking the Portsoy Thrust (Elles, 1931; Ramsay and Sturt, 1979; see Interpretation below). Although deformation is high and smallscale dislocations are present, no major dislocation is now recognized in the sequence. Indeed, as Ramsay and Sturt (1979) showed, there are 'enclaves' of unmigmatized rocks within the migmatitic semipelitic units. Tight folding on very steeply dipping axes, large-scale cuspate structures and shear-zones can readily account for the complex detailed distribution of lithologies. 
Anastomosing shear-zones are found near the south-eastern margin of the Cowhythe Psammite Formation, which is marked on the northwestern side the bay of old Hythe by a steep narrow zone of mylonitic biotite-rich semipelite and tightly folded recrystallized white metalimestones. This structure, termed the Boyne Line by Read (1923), was thought to represent a fundamental regional dislocation in the Dalradian succession, but later work has shown that it does not correspond to a major stratigraphical, structural or metamorphic break (see Interpretation). The structure is further complicated due to the presence of variably orientated, commonly steeply plunging F2 and F3 folds, a later monoform, and faulting (see Read, 1923, figure 5).

Although there are steep dips in parts, the overall bedding and structural profile of the Cowhythe Psammite Formation are only gently inclined. In some areas the bedding is notably lenticular and chaotic zones are present; this seems to be a primary depositional feature. Some idea of the structural complexity is given by the outcrop of the Rosehall croft Limestone on the foreshore and cliffs around NJ 5978 6640, which shows a refolded fold pattern that can be traced over a few hundred metres.

Two main fold generations can be distinguished, an earlier tight folding (F2) with a penetrative cleavage (S2), and a dominant late open to tight folding (F3) with a variably developed crenulation or penetrative cleavage (S3). Fold axes show a wide range of plunge orientations. A moderately plunging rodding lineation (L2) that appears to define the maximum finite extension direction during the D2 deformation episode, traces an arc between south-south-west at Links Bay and west at Kings's Head. Late-stage crenulation cleavages are developed locally in the more-semipelitic lithologies and monoformal structures also deform the earlier D2 and D3 fabrics and folds.

On the foreshore some 250-500 m south-west of East Head, around NJ 667600 , are several small circular to ovoid bodies of ultramafic rock, which hornfels the adjacent metasedimentary rocks. By East Head, the gneises are cut by 3-4 m-thick NNE-trending veins of pink to orange muscovite and tourmaline-bearing pegmatitic granite.

\subsubsection{Tayvallich Subgroup: Boyne Limestone Formation}

The lowest unit of the formation, the old Hythe Semipelite Member consists of purple-grey semipelites interbedded with white to grey metalimestones and calcsilicate-rock bands and lenses. Immediately east of the 'Boyne Line' ductile dislocation, the beds are tightly folded, contain small-scale shears, and show widespread development of a later fracture cleavage. Quartz pods are common. Semipelite outcrops in the central part of old Hythe bay show more-typical structural patterns and sillimanite (fibrolite) has been recorded from these beds.

On the south-eastern side of Old Hythe, spectacularly refolded interbedded metalimestones and calcsilicate rocks of the succeeding Boyne Castle Limestone Member are exposed in the cliffs. F1 and F3 folding is abundant in these white, cream, pale-purple and greenish grey, laminated and thinly banded metalimestones and subsidiary calcsilicate rocks, which are very well exposed on the Craig of 
Boyne (NJ 6163 6612). The distinctive fine-scale lamination, thin cherty layers and pelitic laminae of this unit might relate to an algal, partly stromatolitic origin. The unit has been extensively quarried immediately inland at Boyne Bay Quarry.

On the south-east side of Boyne Bay are thinly bedded, pale-grey to pink-purple, greenish grey and cream, calcsilicate rocks, impure metalimestones and calcareous semipelites. These candy-striped rocks mark the base of the Whyntie Brae Calcsilicate Member and show excellent $\mathrm{F} 3$ and earlier F1 folding with interference patterns common. Fl folds are tight and their axes typically plunge moderately to the north-east or south-west. The superimposed F3 folds vary from open to tight and verge to the north-west, with their axes mainly plunging gently to moderately to the south-west and south-south-west. Overall the beds dip gently to the southeast, but the folding gives rise to steeper dips locally.

At NJ 62156585 a c. 10 m-thick sheet of dark green-grey metadolerite intrudes the calcareous rocks. It is locally discordant to bedding, yet defines an upright, close, NW-verging fold-pair some $70 \mathrm{~m}$ across, interpreted as an F3 structure. At least four further metadolerite sills occur to the east, and an unfoliated hornblende metagabbro body, some 50-60 m thick, crops out around Whyntie Head (e.g. at NJ 6284 6583). These mafic bodies probably relate to the large poorly exposed Boyndie Intrusion that lies some $1.5 \mathrm{~km}$ to the south-south-east.

\subsubsection{Southern Highland Group: Whitehills Grit Formation}

The metagabbro sheet at Whyntie Head marks the base of the overlying Whitehills Grit Formation, which signals a change in the overall depositional facies of the Dalradian succession from shallow-marine shelf to deeper water turbiditic sedimentation. The Southern Highland Group rocks appear to overlie the underlying Argyll Group succession with slight unconformity. The basal lithology is a notably thick gritty psammite, locally calcareous in part. Farther east interbedded psammites, semipelites and pelites are more typical of the formation. A single metalimestone bed occurs near the base of this mixed succession but calcareous psammites and semipelites, and calcsilicate lenses are relatively abundant throughout. The thicker psammite beds are commonly gritty and show coarse to fine grading. A prominent thick, relatively planar bed of massive, cream to fawn calcareous gritty psammite is well exposed on the foreshore at Stake Ness (NJ 6442 598). The bed has an erosional lower contact and shows internal, tight disharmonic folds, interpreted as slump folds. Similar intrafolial folds occur in some of the other thick psammite beds. The lower part of the formation is intruded by metadolerite sheets up to $4 \mathrm{~m}$ thick.

The formation has low overall regional dips but exhibits smalland medium-scale tight F1 folding, mainly along NE- and NNEplunging axes. However, the outcrop pattern is dominated by the more-open, NW-verging F3 folds whose axes plunge gently to the north-east. Fold interference patterns are clearly seen in places. A penetrative S1 cleavage is normally present, but an S3 
crenulation cleavage is only variably developed. Andalusite is seen in the pelitic units and the tops of graded psammite-pelite beds, and staurolite is present in some pelites (Hudson, 1980, 1985) .

\subsubsection{Macduff Formation}

A thick gritty psammite unit forms the promontory and skerries of Craig Neen (NJ 6517 6571) at the western margin of Whitehills village; this effectively marks the end of the calcareous units and the base of the Macduff Formation. A kilometre-thick lower unit, the Knock Head Grit Member is dominated by pelite, semipelite and psammite units with minor calcsilicate lenses in the lower part but the frequency and thickness of intervening gritty psammites increases eastwards until, at Knock Head, pebbly psammites are dominant. From there, the pelitic element increases eastwards towards the west side of Boyndie Bay, where psammite is again subsidiary. The pelitic units commonly show concentrations of large (average c. $1 \mathrm{~cm}$ long) grey elongate 'slugs' of andalusite, and/or black rounded cordierite porphyroblasts, reflecting the respective iron-rich and less common magnesium-rich nature of the protolith muds (Figure 29). Porphyroblasts reflect the grading in the turbiditic units, becoming larger and more abundant in the pelitic tops. Small red manganiferous garnets and brown staurolites up to $2 \mathrm{~mm}$ long are also present. The bedding in the Knock Head Grit Member generally dips east at over $50^{\circ}$. Minor folding is only rarely seen, except near Whitehills where close to tight F1 folds with moderately north-plunging axes are present. D3 effects are mainly limited to development of a coarsely spaced crenulation cleavage in some pelitic units. S3 clearly overprints the porphyroblast growth, which overgrows the earlier S1 cleavage/schistosity (Johnson, 1962; Fettes, 1971; Hudson 1980). This steep zone forms the western limb of the so-called Boyndie Syncline, whose status is discussed below.

The Dalradian outcrops lie close to the Devonian land surface in this area, and small patches of breccioconglomerate are present. In parts the Dalradian rocks are heavily stained red-brown; in other areas the andalusite is stained red, with the pelitic matrix remaining mid to dark grey.

The higher parts of the Macduff Formation occupy the remainder of the coast section from the eastern side of Boyndie Bay to More Head and around Troup Head, which is north-east of the Devonian outlier at Gardenstown. The metamorphism is greenschist facies (biotite grade) and only a single deformation phase is present. Hence, the sedimentary features of the interbedded psammites, semipelites and pelites are clear. Bouma sequences are common, with flame structures, grading, cross-bedding, ripple lamination and mud-flake breccias, all indicative of a turbiditic, density current origin. The psammites, which vary from quartz-rich to micaceous, have gritty and even pebbly bases locally. Good examples can be seen in Tarlair Bay, around $\mathrm{NH} 7188$ 6450. The more-quartzose lithologies commonly form discrete lenticular units and probably represent reworked channel-fill material in an offshore fan. 
At Macduff thin metadiamictite units, with pebbles, cobbles and rare boulders, are interspersed in a turbiditic succession that occurs on the broad hinge of a syncline between NJ 71286491 and NJ 7144 6488. These beds were interpreted as glaciomarine deposits by Sutton and Watson (1954). Stoker et al. (1999) have documented the sequence in detail and confirmed that at least some of the larger boulders are probable dropstones from floating ice (Figure 30).

Metamorphic grade increases from east to west. Rounded dark-grey cordierite porphyroblasts, seen to be altered to pinite in thin section, are first seen in the pelitic units west of Banff Harbour. Farther west at scotstown the cordierites are paler with only partial or marginal dark-grey alteration to pinite. Zoned calcsilicate pods are present locally (Hudson and Kearns, 2000). A little farther west, at NJ 6817 6459, Hudson (1987) recorded the first andalusite porphyroblasts as small whitish grey laths or square-section crystals in cordierite-bearing pelitic units and staurolite appears on the west side of Boyndie Bay in the Knock Head Grit Member.

The rocks of the Macduff Formation are disposed in a series of open to tight Fl folds typified by steeply dipping bedding, well seen on the foreshore at Banff and Scotstown. However, somewhat perversely, the overall or sheet dip is shallow, with the succession defining a very open regional syncline, the Turriff Syncline (Figures 3a, 26). Although it is difficult to correlate the detailed stratigraphy, the upper part of the formation exposed on this coast section could be only 2-3 $\mathrm{km}$ thick.

Farther east at the Howe of Tarlair (NJ 719 646), a thick gritty psammite unit defines an upright Fl anticline-syncline pair with an amplitude of some $130 \mathrm{~m}$ and a wavelength of C. $320 \mathrm{~m}$. F1 axes plunge gently northwards. The related $\mathrm{S} 1$ cleavage is a variably developed pressure-solution cleavage in the psammites but a slaty cleavage in the pelitic units. Cleavage-bedding relationships are well seen and the abundant sedimentary features clearly show that the structures are upward facing. The fold structure is controlled by the thickness of psammite units and generally the folds have a neutral vergence. However, at Stocked Head, the Fl fold vergence changes from neutral to westerly and s-profile folds dominate farther east. Late kink folds are common locally and the F1 structures are refolded by open monoforms. All of these structures lie within the broad axial zone of the Turriff Syncline.

The Gardenstown outlier of Devonian sandstones, siltstones and conglomerates has faulted boundaries against Dalradian rocks, although an unconformity can be seen in a small exposure at Crovie. The Macduff Formation rocks to the north-east that form the peninsula of Troup Head are fault bounded to the south-east and form an isolated enclave. They consist of psammites and pelitic units and have gentle but variable dips. Their overall dip is easterly and they show west-verging close Fl folds. 


\subsection{Interpretation}

\subsubsection{Stratigraphy and sedimentation}

The generally clean, mature nature and ubiquitous cross-bedding of the Cullen Quartzite Formation suggest that the sands were deposited under shallow marine conditions where tidal, wave and current action were important. Slumped units suggest that at times deposition was rapid and local instabilities resulted. The succeeding more-pelitic units probably represent quieter sedimentation conditions dominated by mud deposition under inshore intertidal, lagoonal or estuarine conditions. Similar conditions prevailed during deposition of the overlying Findlater Flag Formation. The clean quartzite units such as the ripple-marked and cross-bedded Findlater Castle Quartzite probably represent shortlived sandy channels (Figure 27). However, the upper parts of the Lochaber Subgroup, as elsewhere in the Grampian Highlands, show a progressive increase in calcareous material. Calcsilicate rocks are abundant and dolomitic metacarbonate rocks, calcareous semipelites, and minor kyanite-bearing rocks characterize parts of the succession. A study of the tremolitic amphiboles that are a major component of the Cairnfield Calcareous Flag Formation revealed that the protolith muds were very high in Mg relative to Ca, with high but variable Al (Stephenson, 1993). The aluminous, magnesian and potassic nature of these lithologies imply input of periodic weathered material, probably under very shallow water, locally evaporitic, partially emergent conditions, with only restricted circulation of seawater (Thomas, 1999). Detrital input of silica and clay minerals was variable and possibly seasonal, giving rise to the colour banding; marl beds with a low detrital component gave rise to the essentially monomineralic paraamphibolites.

The graphitic pelite and metalimestone succession of the Ballachulish subgroup is indicative of a widespread marine transgression across the Dalradian basin, marked by deposition of anoxic or reduced mudstones and chemical or derived limestones. In this section, boreholes have revealed a continuous stratigraphical passage from the graphitic pelites up into overlying thinly bedded semipelites, metalimestones and calcsilicate rocks of the Tarnash Phyllite and Limestone Formation. A return to very shallow water conditions with possible local evaporates is indicated, though without any major influx of detrital siliciclastic material, as represented by the quartzite seen elsewhere at this stratigraphical level. The deposition of graphitic semipelites and pelites and metalimestones, typical lithologies of the Blair Atholl subgroup, signals a further transgression phase.

The Islay Subgroup has a locally developed metadiamictite at the base that relates to a marine glacial event. This was accompanied and followed by local basin formation and deposition of largely siliciclastic sediments. Although the Arnbath Psammite Formation contains a greater proportion of semipelite than is normal at this stratigraphical level, it does contain much sandy material including a quartzite member. The overlying Durnhill Quartzite 
Formation is also reduced in thickness and purity by comparison with its manifestation inland.

The rapid change to more-graphitic and aluminous pelitic rocks of the Easdale Subgroup (Castle Point Pelite and Portsoy Limestone formations) appears to mark a transgression, although this could reflect formation of a local marine basin. The presence of isolated quartzite lenses, a pebbly quartzite unit, and mixed metalimestone-graphitic pelite-quartzite units suggests that the palaeoenvironment and sediment provenance were locally varied. The overlying Cowhythe Psammite Formation, assigned to the Crinan Subgroup, is highly metametamorphosed, structurally complex and partly migmatitic. However, in places in the psammite and semipelite unit there are suggestions of grading, disrupted bedding, and slumped or chaotic units. The beds might have been turbiditic and if that was the case they would represent the infill of a local deeper water basin. The rapid transition up into semipelites and metalimestones of the Boyne Limestone Formation (Tayvallich Subgroup) represents a shallowing, with marine shelf conditions becoming dominant. The thick metalimestones in this formation show laminae and small-scale structures suggestive of algal reef growth, implying that warm shallow conditions prevailed. The overlying calcareous semipelites and calcsilicate rocks were originally marls and possible evaporitic deposits, suggesting possible lagoonal conditions with some local emergence.

This quiet shallow marine-shelf deposition was interrupted by the incoming of the first turbiditic units of the Southern Highland Group and signalled the development of a deeper marine basin that developed subsequently into the Iapetus Ocean. The lowest psammite unit of the Whitehills Grit Formation appears to cross-cut the underlying Argyll Group succession regionally, suggesting that it might mark a slight angular unconformity. The sediments deposited ranged from coarse siliciclastic to muddy but contained a large component of derived carbonate material, probably from nearby reefs. The succeeding Macduff Formation consists of psammites and intervening pelitic units that show excellent features typical of turbiditic fans. The rocks have been interpreted as channel, overbank or outer-fan deposits, depending on the coarseness of the units, Bouma features and lithological associations (Kneller, 1987). Hence, the Knock Head Grit Member represents a channel environment, whereas the adjacent more-pelitic succession represents an interchannel or perhaps outer-fan environment.

The Macduff Boulder Bed, which lies near the top of the stratigraphical sequence in this GCR site, has been interpreted as a glaciomarine deposit with slumped units and dropstones (Figure 30) (Sutton and Watson, 1954; Hambrey and Waddams, 1981; Stoker et al., 1999). By analogy with Pleistocene deposits offshore to the north-west of the British Isles, such glacigenic deposits are characterized by debris-flow packages and the Macduff succession is compatible with distal deposition in a base-of-slope or basin-plain situation, with a water depth of over $1000 \mathrm{~m}$. The deposit has been correlated with Ordovician glacial episodes on the basis of a single acritarch Veryhachium lairdii collected from adjacent pelitic units (Molyneux, 1998). However, failure to replicate this find and its atypical state of preservation despite metamorphism to 
biotite grade cast doubt upon the acritarch evidence, which should probably be discounted at the present time. Hence, the glacial deposits more likely correlate with dropstone localities near the base of the Southern Highland Group in Donegal (Condon and Prave, 2000), which would imply that only the lowermost parts of the group are exposed in the North-east Grampian Highlands, albeit in a relatively thick sequence.

\subsubsection{Structure}

Figure 26 shows the composite cross-section along the coast, based upon recent British Geological Survey mapping and the overall structure is illustrated in Figure 3a. Note that on these sections, the areas of steeply dipping succession have been much reduced, compared with previously published sections (e.g. Sutton and Watson, 1956; Treagus and Roberts, 1981). This has several consequences: the stratigraphical succession is thinner than formerly estimated; the Boyndie syncline is reduced to a smaller scale steep zone with more-gently dipping, locally subhorizontal beds on either side; the Cowhythe Head and Redhythe Point areas, that lie respectively east and west of the Portsoy Shear-zone, also show regionally shallow dips. In detail many parts of the coastal section show alternating steep and shallow dipping zones and it is unclear as to their age relative to main phases of folding and related cleavage formation. The following discussion progresses broadly from higher structural levels in the east of the section to deeper levels as seen in the west.

The linked concepts of the Boyne Line and the SE-facing Banff Nappe were introduced by Read (1955) to explain the major structure of the North-east Grampian Highlands (see 1.2.2 in Introduction; Figure 3b). Along much of the coast section east of Boyne Bay, the rocks exhibit locally complex F1 folding with steep dips, but regionally they are the right way up and are disposed in a broad, gentle syncline, the Turriff Syncline, which would constitute the upper limb of the nappe in Read's model. The overall structural and metamorphic sequences of this section are quite well understood due to detailed studies of the minor structures (Johnson, 1962; Loudon, 1963; Fettes, 1971; Treagus and Roberts, 1981). Early (F1) folds and related cleavages face consistently upwards and the style of the folds varies according to structural level, being generally upright and open to close at the highest levels in the centre of the Turriff Syncline and generally recumbent and tight on the limbs. Across the whole section F1 folds face to the north-west, apparently contrary to Read's (1955) model of a SE-facing Banff Nappe. However, Read attributed these folds to gravitational flow on the western limb of the Buchan Anticline, which he envisaged as having developed as an early structure accompanying nappe formation.

Post-D1 structures are restricted to the lower structural levels and hence are seen only on the western and eastern limbs of the Turriff syncline. There is some confusion, particularly in the Portsoy area, as to the number of major fold phases that can be identified, and their relationship to regional D2 and D3 defined elsewhere in the Grampian Highlands. Both Johnson (1962) and 
Treagus and Roberts (1981) have identified separate D2 and D3 phases but differ as to their distribution and interpretation. Their conclusions are incorporated in the following summary, which is based largely on that of Kneller (1987). D2 folds and cleavages are recognized only to the west of the Boyne Limestone outcrop and to the east of Fraserburgh Bay. In the area around Portsoy, F2 folds are locally dominant. Those folds have steeply plunging axes, which are colinear with a very strong stretching lineation attributed to thrusting and focussed along the Portsoy Shear-zone.

The D3 deformation, which post-dates the peak of metamorphism and main growth of porphyroblasts east of Boyne Bay, has limits that effectively coincide with the andalusite isograd. Large-scale F3 folds are characteristically open to close and monoclinal in form. Associated finely spaced cleavages and tight crenulation cleavages occur in the more-pelitic units and small-scale open to tight fold structures are well seen in the more-banded units. The Turriff Syncline and Buchan Anticline have been tentatively attributed to the D3 phase by several authors. However, west of Whitehills, smaller scale D3 structures have easterly to south-easterly dipping axial planes and a westerly vergence. It is difficult to correlate these D3 structures with the open and upright character of the Turriff Syncline, which is more compatible with major D4 structures elsewhere. Numerous sets of minor kink and brittle folds in the area, notably in the pelitic lithologies, are attributed to later events.

Steeply dipping beds on the western limb of the Turriff Syncline are the result of a monoform, regarded as a major fold closure predating the metamorphic peak by Sutton and Watson (1956), who named the structure the Boyndie Syncline. However, Read (1923, 1955), who concentrated firstly on the stratigraphy and secondly on the regional structural interpretation, portrayed the syncline merely as a perturbation on the top limb of the Banff Nappe. Subsequently Johnson (1962) and Fettes (1971) recognized two fold phases in the Whitehills area and allocated the Boyndie Syncline to the secondary phase, which they termed D3. They argued that the syncline folds the metamorphic isograds and hence post-dates the metamorphic peak. Treagus and Roberts (1981) argued that F1 folds consistently face upwards along the coast section and favoured a D1 age for the Boyndie syncline. The structural evidence and metamorphic pattern would be compatible with formation of the steep zone during or prior to D1, followed by superimposition of the metamorphic pattern and D3 deformation. This would accord with other coastal sections where F3 folds appear to be superimposed on a stepped profile.

The Boyne Line as envisaged by Read (1955) underlies the Banff Nappe and separates it from the Argyll and Appin group succession to the west; it is a 'lag' rather than thrust structure, i.e. younger rocks are juxtaposed over older rocks (Figures 3b, 26). Ashworth (1975) argued strongly against Read's model, preferring Horne's original idea of sedimentary facies variations to explain the absence of the Boyne Limestone Formation to the south (Horne, in Read, 1923, p.72). Most authors agree that later faulting is also present. However, the presence of biotite-grade mylonitic rocks at old Hythe and the local deformation patterns do suggest that it is the site of a steep shear-zone, possibly with lateral 
movement. That said, there is no metamorphic hiatus and moderate structural continuity is retained across the section. The structure may well be linked to the Portsoy Shear-zone that crops out to the west but there is no need to invoke a Boyne Line sensu Read (1955) .

Between the putative Boyne Line and the Portsoy Shear-zone, Sturt et al. (1977) and Ramsay and Sturt (1979) recognized a complex structural history in the Cowhythe Psammite Formation and allocated the migmatitic gneissose rocks to a pre-Dalradian basement unit formed in the Neoproterozoic. They maintained that the contact of the migmatitic semipelite at the base of the Cowhythe Psammite is visibly discordant with the structurally underlying calcareous psammitic and semipelitic succession to the west along the Portsoy Thrust, thus resurrecting Read's concept of an allochthonous succession in Buchan. However, most workers regard the gneisses as migmatized equivalents of the upper parts of the Argyll Group (see 1.1.3 in Introduction).

The Portsoy Shear-zone shows evidence of a complex and lengthy tectonic history (Goodman, 1994), as discussed on a regional basis in section 1, Introduction. The main problems associated with the structure are to reconcile its identities as an initially steep lineament, a subsequent shallow dipping shear-zone, and a steep fault/shear-zone along which preferential uplift later occurred. Although evidence for these three manifestations is present on the coast section, it is unclear as to how and where the different elements might be projected at depth or farther south to Deeside and beyond. Local and regional stratigraphical patterns imply that a lineament could well have been active at the time of Argyll Group sedimentation (Fettes et al., 1991). The main tectonic activity was focussed in mid-Ordovician time at around $470 \mathrm{Ma}$ when thrusting to the west-north-west and associated deformation, metamorphism and fluid flow, occurred roughly coeval with intrusion of basic and ultrabasic bodies (Baker, 1987; Oliver, 2002). The overprint of kyanite after andalusite to the west of the shear-zone reflects a pressure increase of $c .2$ kbar at this time, consistent with an increase in overburden of 6-7 km (Beddoe Stephens, 1990). Later steep shear-zones, along which granitic veins are intruded in parts, are well seen around Portsoy and show foliations and geometries indicative of dextral shearing.

The position of the Keith Shear-zone on the coast section is marked by strong planar and linear fabrics and localized migmatization of Islay Subgroup rocks around Foul Hole just west of Portsoy. Shear-sense indicators imply top-to-west movement. The shearing post-dated both lithification of these rocks and intrusion of the Keith-Portsoy Granite and was most likely associated with the Grampian Event in mid-Ordovician time. Just inland, at Boggierow, the granite has been reliably dated at C. $600 \mathrm{Ma}$ and is interpreted as having been intruded into an early lineament that was subsequently re-activated as the shear-zone, thereby providing a minimum age for its initiation. A full appraisal of the shearzone and its associated intrusions, incorporating evidence from outwith this GCR site, is given in section 1.2.1 in Introduction.

Farther west in the Appin Group rocks, two phases of penetrative deformation are seen, manifested as folding and related planar and 
linear fabrics. These structures are particularly clear in the pelitic and metalimestone lithologies, but it is uncertain whether they should be attributed to D1 and D2, D2 and D3, or D1 and D3. By analogy with deformation chronologies farther south they are generally attributed to D2 and D3. In fact, Peacock et al. (1968) showed that to the south-west of Cullen, the penetrative early fabrics and folds attributed to D2 post-date an earlier beddingparallel schistosity that they termed S1.

\subsubsection{Regional Metamorphism}

The Cullen-Troup Head section remains one of the classic areas for studying the nature of the relatively low-pressure and hightemperature Buchan-type metamorphism (Read, 1952). Many studies have documented the transition from greenschist facies in the Macduff-Gardenstown area to lower and upper amphibolite facies in the Portsoy and Fraserburgh areas (Johnson, 1962; Chinner, 1966; Fettes, 1971; Hudson, 1980, 1985; Hudson and Harte, 1985; Johnson et al., 2001a, 2001b). The occurrence of upper amphibolite-facies assemblages (sillimanite-potash feldspar) in the Cowhythe and East Head area and granulite-facies assemblages east of Fraserburgh Bay (see the Cairnbulg to St Combs GCR site report) was shown by Ashworth (1975) and Johnson et al. (2001b) to relate to mafic intrusions of the North-east Grampian Basic Suite. Pressure and temperature conditions ranged from $1.2 \mathrm{kbar}, 400^{\circ} \mathrm{C}$ in the lowest biotite-grade rocks to $1.8 \mathrm{kbar}, 490^{\circ} \mathrm{C}$ at the andalusite isograd and 3.3 kbar, $545^{\circ} \mathrm{C}$ at the sillimanite isograd (Hudson, 1985). The higher grade rocks reached $4.2 \mathrm{kbar}, 630^{\circ} \mathrm{C}$, values consistent with pressure-temperature estimates derived from the hornfels mineralogy of larger mafic intrusions (Droop and Charnley, 1985).

The Buchan metamorphic peak occurred following the D1 deformation but mainly prior to the later D3 event (Johnson, 1962, 1963). Porphyroblasts overgrow generally planar S1 fabrics, but thinsection studies from several rocks in the Inverboyndie area show that cordierite overgrowths also occurred synchronous with D3 deformation (Phillips, 1996). A later phase of retrogressive metamorphism characterized by chlorite and sericite (muscovite) is found in many of the rocks, in parts associated with late-formed structures.

The metamorphic pattern has influenced both the original lithological divisions and former tectonic models for the Buchan area. Read (1923) defined several lithological units on the basis of their metamorphic features. Thus, the former Boyndie Bay 'group', west of Banff, which is characterized by andalusite schists, is now regarded as merely the lower part of the Macduff Formation. Similarly, to the south-east, the Macduff Formation grades downward into the 'Fyvie Schist', which is characterized by andalusite and cordierite porphyroblasts giving a 'knotted' appearance and is now placed in the Methlick Formation. He also erected the Boyne Line on the basis of a supposed metamorphic hiatus between his overlying 'Banff division' and underlying 'Keith division' rocks. However, Ashworth (1975) dismissed the evidence for a metamorphic hiatus and showed that the metamorphic zones appeared to be superimposed on the early-formed structural pattern. 
Hence, he rejected the concept of both the Boyne Line and the Banff Nappe.

Within the Portsoy Shear-zone the metamorphic mineralogy is undoubtedly complex. By the Portsoy swimming pool (at NJ 5844 6648), graphitic pelite shows apparent andalusite (chiastolite) porphyroblasts. However, in thin section a different picture emerges. Large andalusites are partly pseudomorphed by blocky kyanite, set in platy to felted muscovite. Ragged early staurolite with sigmoidal inclusion trails and smaller, later, more-euhedral porphyroblasts are also present. Garnets are ragged and show evidence of partial dissolution. The biotite-rich fine-grained schistose matrix is deflected around the andalusites but platy muscovite and kyanite overgrow this fabric locally. Fibrolitic sillimanite also occurs, which on textural evidence pre-dates growth of small kyanite blades (Beddoe-Stephens, 1990). Although the mineralogy gives us a record of at least parts of the lengthy metamorphic history of this rock, it is difficult to unravel which mineral associations were in equilibrium at each stage.

West of the Portsoy Shear-zone, porphyroblast growth occurred at several times. Garnet and biotite formed both prior to and synchronous with formation of the s2 fabric; the metamorphic minerals are wrapped by the later amphibolite-facies schistosity and show some resorption or alteration (Peacock et al., 1968). Beddoe-Stephens (1990) showed that the Buchan-type assemblages were present in this area but were subsequently overprinted under higher pressure conditions during the D3 deformation (see the Auchindoun Castle GCR site report). It is this event that deformed the KeithPortsoy Granite, implying thrusting to the west-north-west, probably with movement focussed along the Portsoy and Keith shearzones.

\subsection{Conclusions}

The coast between Cullen Bay and Troup Head provides the longest continuous section across the strike of the Dalradian succession in Scotland. It extends from the top of the Grampian Group to the highest preserved beds of the Southern Highland Group and is the type section for the Argyll and Southern Highland groups of the North-east Grampian Highlands. It records the progression from deposition in a shallow marine gulf in an intracontinental rift that became a series of fault-bounded deeper sedimentary basins on a continental shelf heralding the opening of the Iapetus ocean, to deposition from turbidity currents in major sub-marine fans on the subsiding shelf and continental slope.

The coast also provides a near-complete structural and metamorphic transect across the Dalradian outcrop. The beds are basically the right way up and range from steeply dipping in the west to regionally shallow dipping in the core of the Turriff syncline to the east. The succession is interrupted by several major dislocations, each of which probably marks the site of a fundamental structure with a long history extending back to the time of sedimentation. The Keith Shear-zone intersects the coast west of Portsoy; it does not remove or repeat much of the succession but it does include granite dated at 600 million years 
old. At Portsoy, a 1 km-wide zone of shearing that involves various 470 million year-old mafic and ultramafic intrusions marks the position of the Portsoy Shear-zone and the Portsoy Lineament. The latter structure seems to have acted as a controlling feature at the time of sedimentation, and through the deformation, metamorphism and magmatism of the Grampian Event. It separates the so-called Buchan Block to the east, which exposes higher stratigraphical levels and exhibits higher-level structures and low-pressure regional Buchan-type metamorphism, from structurally and stratigraphically lower level, higher pressure rocks to the west that seem to be a continuation of the sequences and structures typical of the Central Grampian Highlands.

The nature and origin of the Buchan Block and of its boundaries have been a constant source of discussion. It has clearly been decoupled at times from the adjacent terranes and possibly from the lower parts of the originally underlying Dalradian rocks; it has even been suggested that it might have been a separate allochthonous terrane with an entirely different sedimentological, structural and metamorphic history to the remainder of the Grampian Terrane. However, within this GCR site it could be argued that elements of both the stratigraphy and the structure are continuous across the Portsoy Shear-zone and relics of the Buchan metamorphism have been identified up to $10 \mathrm{~km}$ farther west, casting doubt on suggestions of large-scale regional displacement.

The coast section has contributed to speculation on the age of the Dalradian. At least the lower parts of the succession must be older than the 600 million year-old Portsoy Granite, and the highest parts have reportedly yielded some poorly preserved microfossils. An Ordovician age has been suggested, both from the microfossils and from the presence of glacigenic boulders that have been attributed to a late-Ordovician glacial period, but this interpretation cannot be reconciled with the dating of metamorphic events or the Dalradian succession elsewhere.

Most of this GCR site is well exposed and readily accessible, except for parts where the cliffs are particularly steep. With thick superficial deposits characterizing the hinterland this reference section is therefore extremely important in a national and possibly an international context. It has been the subject of more research and more publications than any other part of the Dalradian outcrop and is used extensively for teaching purposes. Yet there is so much about it that is still to be learned.

\section{FRASERBURGH TO ROSEHEARTY (NK $001 \quad 663-\mathrm{NJ} 918$ 668)}

\section{D.J. Fettes}

\subsection{Introduction}

This GCR site comprises the coastal section running westwards from Fraserburgh harbour to Rosehearty. It is separated from the Cairnbulg to St Comb GCR site by the wide, sandy expanse of Fraserburgh Bay. Because the section runs for most of its length 
at almost right angles to the regional strike and the main structures, it provides an excellent geological profile. It is of interest for three main reasons. Firstly, it exposes a transition from the calcareous rocks and metagreywackes of the Tayvallich Subgroup (Argyll Group) into the overlying andalusite schists and metagreywackes of the Southern Highland Group. Secondly, it provides a section through the western limb of the Buchan Anticline (corresponding to the eastern limb of the Turriff Syncline) and clearly demonstrates the nature of the first and second deformational phases. Thirdly, the rocks display excellent examples of Buchan metamorphism and the transition from the andalusite schists to sillimanite-bearing schists and gneisses.

The geology of the area was first described by Grant Wilson (1882, 1886) but the basis of the modern interpretation lies in a series of papers by H.H. Read on the Buchan area (Read, 1952, 1955) that culminated in a paper on the Buchan Anticline (Read and Farquhar, 1956). The detailed sedimentology and structure of the area was first interpreted by Loudon (1963) as part of a wider study of the upper Dalradian. Subsequently important contributions were made on the structural and metamorphic history by Fettes (1968, 1970), on the nature of the metamorphism by Hudson (1975) and Harte and Hudson (1979), and on the sedimentology and structure by Kneller (1988). An excursion guide to the eastern part of the site was provided by Kneller (1987).

\subsection{Description}

The coastal section (Figure 31) provides almost continuous exposure along its length of c. $9 \mathrm{~km}$, which comprises a series of low cliffs, rocky foreshores, small sandy bays and the rugged headland of Kinnairds Head. The stratigraphy youngs to the west away from the core of the Buchan Anticline, whereas the metamorphic grade rises to the east, towards the anticlinal core.

\subsubsection{Stratigraphy and sedimentation}

The eastern part of the section, from Fraserburgh harbour westwards to Broadsea at around NJ 988 676, is dominated by calcareous turbiditic units, including some partial Bouma sequences (Kneller, 1987). Kneller also reported a slump breccia around NJ 998677. The sequence is characterized by impure sandy metalimestones, calcareous psammites and calcsilicate bands and nodules that together constitute the Kinnairds Head Formation (Figure 32). Calcareous rocks also occur in an isolated exposure south of the harbour at NK 002 664. The contact with the underlying gneisses of the Cairnbulg to St Combs GCR site is not seen.

The section from Broadsea to Rosehearty consists of tubiditic rocks with graded units and typical elements of Bouma cycles. The bedding is on the centimetre to metre scale. Various sedimentary features can be seen including rip-up-clasts and convoluted bedding; coarse pebbly psammite units might, in part, represent channel fills. Good examples of sedimentary structures can be seen throughout the section, for example at NJ 952 673, and partial and complete Bouma cycles may be examined around NJ 986 673. One 
rather spectacular rock type that dominates much of the section consists of regular graded units, which are characteristically 20$30 \mathrm{~cm}$ in thickness and consist of a finely layered psammite base succeeded by pelite. The pelites, which comprise the greater part of the graded unit are now recrystallized to coarse-grained andalusite schist giving the appearance of reverse grading (Figures 33, 34). These rocks may be examined around Rosehearty and on the foreshore west of Sandhaven. In general the rocks provide excellent and abundant way-up evidence and allow the larger folds to be traced out. This part of the section constitutes the Rosehearty Formation.

The boundary between the Kinnaids Head and Rosehearty formations is marked by the relatively sharp disappearance stratigraphically upwards of calcareous material. However the background sedimentation remains essentially unchanged with partial and complete Bouma sequences identifiable throughout the section.

\subsubsection{Structure}

Minor folds ranging from centimetre scale up to amplitudes of tens of metres are abundant throughout the section. There are two generations of deformation present, defined as D1 and D3 on the regional classification. The Fl folds are present throughout the section. They trend approximately north to north-east, and are subhorizontal or plunge gently to the north at up to $20^{\circ}$. The characteristic structural profile shows a series of gentle vertical or subvertical folds. In places along the section, these become tightened to form asymmetric folds, which are steeply inclined or overturned to the west with inverted limbs. In some cases the axial planes become curved with fold noses 'drooping' to the west. Way-up and cleavage-bedding relationships show that the folds face consistently up to the west. The nature of D1 folding and cleavage relationships is well seen on the foreshore around Sandhaven and westwards to NJ 950 679, as well as in the area to the west of Rosehearty harbour. Minor folds are spectacularly developed in the mixed calcareous lithologies to the west of Kinnaird Head. S1 axial planar fabrics are developed throughout the section. Cleavage planes that cross-cut the lithological banding in the andalusite schists are spectacular between Rosehearty and Sandhaven (Figures 33, 34).

The F3 folds are broadly coaxial with the F1 folds and are overturned to the west, as seen for example at NJ 985673 and NJ 998 677. They can be clearly shown to refold D1 structures and excellent examples of refolded folds can be seen below the foghorn at NJ 998677 (Figure 32). Kneller (1987) also reported refolded structures at NK 001 675. S3 axial planar fabrics are sporadically developed and in places are associated with microfolds of S1. S3 characteristically forms a spaced clevage, for example at NK 001 675 .

\subsubsection{Metamorphism}

Andalusite and cordierite are present throughout the section with spectacular coarse-grained andalusite schists characterizing the 
outcrops between Rosehearty and Sandhaven. Typical assemblages are quartz-plagioclase-biotite-andalusite-cordierite. At Kinnairds Head fibrolite appears, reflecting the general increase of grade to the east. Kneller (1987) reported mixed assemblages in the calcsilicate rocks, including calcic amphiboles, diopside, epidote and zoisite. Fettes (1968) showed quite clearly that the peak of metamorphism, marked by the major prophryroblast development, took place in a static phase between D1 and D3, the porphyroblasts overgrowing the S1 fabrics and being broken or rotated during D3 and mantled by the 53 fabrics.

\subsubsection{Igneous and meta-igneous rocks}

A coarse amphibolitic rock is shown on the BGS 1:10 000 sheets immediately south of Fraserburgh harbour. In addition, Kneller (1987) reported a number of igneous or meta-igneous rocks around Kinnairds Head. He described a large crag in the middle of a small bay at NK 000 675, which is composed of biotite-actinolite schist and is apparently conformable with the bedding. Kneller also described a similar, although less mafic 'greenstone', below the harbour wall at NK 001 675. He noted that the mottled appearance of the first occurrence is reminiscent of metamorphosed basic tuffs found at similar stratigraphical horizons elsewhere in the Tayvallich subgroup. A number of aplitic and pegmatitic leucogranite sheets (for example at NJ 998677 and NJ 993 674) have sharp contacts and post-date all the deformation structures; they most probably relate to the late-Caledonian granites.

\subsection{Intreptation}

Sedimentological features clearly indicate that the rocks are tubiditic and typical of the unstable conditions prevalent at the time. This background sedimentation persists throughout the section (see Kneller, 1987), although there is a relatively sharp junction between the part of the succession that includes calcareous rocks in the east and the part devoid of calcareous lithologies to the west. The section comprises the Kinnairds Head and Rosehearty formations (previously called 'groups' by Read and Farquhar, 1956). The Kinnairds Head Formation is correlated with the Tayvallich Subgroup (Argyll Group) and the Rosehearty Formation is correlated with the lower part of the Southern Highland Group. The Kinnairds Head Formation was previously regarded as equivalent to the Whitehills 'group' in Banffshire. However the BGS 1:50 000 Sheet 96 (Banff, 2002) has placed the lower part of the Whitehills 'group' in the Boyne Limestone Formation (Argyll Group) and the upper part in the Macduff Formation of the Southern Highland Group. This division is made on the first appearance, stratigraphically upwards, of distinct, coarse-grained turbiditic units, albeit within the part of the sequence that contains calcareous lithologies. This boundary has no apparent equivalent in the Rosehearty to Fraserburgh section, which obviously complicates stratigraphical correlations across the Turriff syncline and questions the previously established criteria for delineating the 
top of the Argyll Group at the top of the calcareous sequence (Harris and Pitcher, 1975).

Read (1955) postulated that the rocks of the Buchan Block constitute the upper limb of a recumbent Banff Nappe, an allochthonous eastward-facing structure lying above a major dislocation (the Boyne Line). The nappe structure was seen as having been gently folded into the upright Turriff Syncline and complementary Buchan Anticline. Read and Farquhar (1956) argued that the Buchan Anticline was formed by an upsurging core of gneissose rocks related to the translation of the Banff Nappe. They postulated that the westward vergence and sense of movement of the folds indicated that the metasedimentary pile had slumped off the uprising anticline as a form of gravity slide. This view was questioned by Loudon (1963) and it is now generally discounted. The westward-verging F1 folds are consistent with those found throughout the Aberdeenshire and Banffshire area and this is evidence against a major D1 structure in the area. The westward vergence of the D3 structures on the western limb of the Buchan Anticline is also inconsistent with that structure being of D3 age, suggesting, as noted elsewhere, that the Buchan Anticline might be a relatively late structure, possibly of D4 age.

Read (1955) and Read and Farquhar (1956) believed that the metamorphic pattern was imposed as a thermal aureole around the upsurging gneisses in the core of the Buchan Anticline and was essentially post deformation. Although the metamorphism is indeed superimposed on the main structures, it is obvious that the isograds are folded by the Buchan Anticline and the Turriff Syncline. It is also clear from microstructural studies that the metamorphic and thermal peak pre-dates the D3 and D4 structures (Fettes 1968, 1970).

This coastal section, along with the adjacent Cairnbulg to st Combs GCR site, exhibits typical Buchan metamorphism, characterized by the zonal sequence cordierite $\rightarrow$ andalusite $\rightarrow$ sillimanite $\rightarrow$ sillimanite+K-feldspar. Along with the Ythan gorge to the south, these are the key exposures of the lowest P/T-style of metamorphism (i.e. the lowest pressure/temperature ratios) present in the Dalradian (the Buchan metamorphism as seen in Banffshire is characterized by higher $P / T$ values and the zonal sequence cordierite $\rightarrow$ andalusite $\rightarrow$ staurolite $\rightarrow$ kyanite) (Harte and Hudson, 1979). The generally low $P / T$ values of Buchan metamorphism compared to the Barrovian areas might reflect a relatively unthickened crust (Strachan et al., 2002): the role of the basic intrusions of the North-east Grampian Basic suite in this situation, as either the cause or an effect of high heat-flow, is uncertain. However, it is reasonable to note that the basic intrusions, over much of their outcrop, are associated spatially with the gneisses that represent the culmination of Buchan metamorphism. Thus, Read and Farquhar's suggestion of an aureole around a thermal gneiss dome might not be entirely wrong.

\subsection{Conclusions}

The superbly exposed coastal section between Rosehearty and Fraserburgh is critical to understanding the geology of the Buchan 
Block, which differs significantly in its structural and metamorphic history from the Dalradian successions to the west and south. It is of the highest national importance for three main reasons. The sedimentological and stratigraphical evidence demonstrates the nature of the Argyll Group-Southern Highland Group transition, highlighting both similarities and contrasts with the Perthshire and Banffshire successions. The structural history provides a major piece of evidence to suggest that major D1 structures are absent from the Buchan Block, which is in marked contrast to the major nappe-dominated structures of Perthshire. The spectacular andalusite schists between Rosehearty and Sandhaven and the transition to the sillimanite schists at Fraserburgh constitute one of the type sections of Buchan metamorphism in the Grampian Highlands, which is of international interest as one of the first well-documented examples of low-pressure-high-temperature regional metamorphism in the world.

\section{CAIRNBULG TO ST COMBS (NK $031 \quad 654$-NK 062 626)}

\section{J.R. Mendum}

\subsection{Introduction}

The coastal foreshore between Cairnbulg and St Combs, at the northeastern tip of the Grampian Highlands, provides an across-strike section through migmatitic semipelites, pelites and psammites of the Inzie Head Gneiss Formation (Crinan Subgroup) that are intruded by numerous sheets, veins and irregular lenses of diorite and granite. The metasedimentary rocks show evidence of amphiboliteto granulite-facies metamorphism and anatectic melting. They have been variously interpreted as gneissose basement forming the core of the Banff Nappe (Read and Farquhar, 1956), allochthonous Neoproterozoic basement gneisses (Ramsay and Sturt, 1979), and migmatitic Argyll Group semipelites that have been subject to partial melting (Kneller, 1987; Johnson et al., 2001a, 2001b). These different designations have important consequences for models of the structural and metamorphic history of the North-east Grampian Highlands.

The gneisses lie in the core of the Buchan Anticline and their outcrop extends south-west in a broad swathe to Mintlaw. Their distribution, and western and eastern transition through the morecalcareous Strichen and Kinnairds Head formations (Tayvallich Subgroup) and into the overlying southern Highland Group turbiditic succession, suggests that they are Argyll Group rocks that belong to the Crinan Subgroup. Thus, they are considered to be laterally equivalent to the Cowhythe Psammite Formation, the Ellon Formation, the Aberdeen Formation, the Queen's Hill Formation and the Ben Lui Schist Formation (including the Duchray Hill Gneiss Member). All of these lithological units generally show amphibolite-facies metamorphic assemblages, ranging from garnet to sillimanite grade, but in parts the mineral assemblages imply that conditions reached granulite facies. In the Cairnbulg-St Combs section, peak 
metamorphic temperatures of over $775^{\circ} \mathrm{C}$ and pressures of 3-4.5 kbar have been inferred (Johnson et al., 2001a). Many of the rocks have experienced significant retrogression, resulting in extensive chlorite and sericite replacement of the high-grade mineralogies.

The area was first mapped as part of the primary geological survey of one-inch sheet 97 and a brief account of the gneissose and intrusive rocks was given in the sheet memoir (Grant Wilson, 1882). Somewhat later, H.H. Read and O.C. Farquhar visited the coastal sections, as the Inzie Head gneisses were integral to their model of the Banff Nappe (see Read, 1955; Read and Farquhar, 1956). Sturt et al. (1977) obtained a Rb-Sr isochron from gneisses at Cairnbulg Point that gave an age of c. $691 \mathrm{Ma}$, which was accepted by Ramsay and Sturt (1979) as dating the migmatization. They modified Read's hypothesis of the Banff Nappe and described a complex and lengthy history for the gneisses, which they considered to be allochthonous basement. Subsequently, Kneller (1987) described the Cairnbulg-Inverallochy coast section and noted that migmatization post-dated most of the deformation. He also mentioned the presence of a gravity and magnetic anomaly beneath the area implying the presence of a basic intrusion at shallow depth. Later petrographical and geochemical work by Johnson (1999) has documented the high-grade metamorphic assemblages, migmatitic textures and detailed migmatite-granitic melt relationships together with a link to mafic rocks of the North-east Grampian Basic Suite (Johnson et al., 2001a, 2001b, 2003).

\subsection{Description}

The Cairnbulg-St Combs coastal section (Figure 35) is some $4.7 \mathrm{~km}$ long and encompasses rocky foreshore, smooth glacially scoured rock platforms, and sandy bays, all within the intertidal zone. Blown sand backs much of the coast and there is no bedrock exposure immediately inland.

The compositional banding and accompanying foliation in the Inzie Head Gneiss Formation dip at between $40^{\circ}$ and vertical towards the north-west and west. The foliation is composite but basically reflects the D2/3 deformation that accompanied the main period of migmatization and partial melting. The section appears to lie on the north-west limb of the open Buchan Anticline but it is not possible to determine the detailed structural profile owing to the degree of migmatization, partial melting, and number of intrusive sheets present. In places early tight folds (F1) with axial planes subparallel to the bedding are cross-cut by migmatitic segregations and leucogranite veins (Johnson et al., 2001b).

The metasedimentary rocks consist of thin- to medium-bedded, semipelite, micaceous psammite and feldspathic psammite with pelite interbeds and subsidiary calcsilicate pods and lenses. Where migmatized, the calcsilicate pods have remained relatively refractory and obviously behaved in a more brittle manner. In places a 'ghost' bedding can be reconstructed from their incidence. In the more-feldspathic psammites a spaced cleavage resembling that seen in Southern Highland Group psammites of the ColliestonWhinnyfold and Rosehearty areas is present. The psammite has been recrystallized and the defining mineralogy is now high grade, but 
the relict nature is still apparent. In places, pelitic rocks show prominent cordierite and more-rarely andalusite porphyroblasts. Sillimanite is common throughout the section.

Kneller (1987) was the first to mention the different types of migmatite that can be seen in the section but Johnson (1999) has mapped and studied their distribution and origin in detail. The migmatites show variable development of segregation and partial melting giving rise to abundant quartzofeldspathic material, termed leucosome, which in most places resembles a pale-grey mediumgrained leucocratic granite. The material remaining after loss of melt is termed melanosome and is richer in biotite and plagioclase feldspar. Johnson et al. (2003) described the leucosome in thin section as consisting of quartz, variably zoned plagioclase, cordierite, biotite and potash feldspar with apatite, zircon and opaque phases, mainly ilmenite as accessory minerals. Garnet, orthopyroxene, tourmaline, muscovite and andalusite can occur as additional phases. Potash feldspar is commonly altered to myrmekitic blebs where it is in contact with plagioclase, and larger muscovite and quartz symplectites, common in some leucosomes, are interpreted as pseudomorphs after potash feldspar. Many of the minerals are altered and pseudomorphed in these rocks, with cordierite invariably altered to shimmer aggregate of chlorite and white mica (rarely pinite) and no pristine orthopyroxene preserved. The amount of leucosome present increases from northwest to south-east with a concomitant decrease in the size and abundance of the relict metasedimentary rocks (termed schollen).

Johnson et al. (2001b) distinguished three main migmatite zones based on the mineralogy of the leucosomes; Leucosome-cordierite (Lcrd), Leucosome-garnet (L-gt) and Leucosome-orthopyroxene (L-opx). The indicator minerals, cordierite, garnet and orthopyroxene, which formed at the time of melting of the metasedimentary host rock, were in equilibrium with the melt and are termed peritectic phases. Figure 36 shows the distribution of the various migmatite types and diorite and major granite sheets across the section.

The limit of melting, marked by initial generation of leucosome, is now concealed beneath Fraserburgh Bay. However, exposures at West Haven and Cable Shore, south-west of Cairnbulg Point show sections with less than $10 \%$ leucosome in the effectively unmodified metasedimentary mesosome, the resulting migmatite being termed a metatexite. The leucosome occurs as small blebs or discontinuous streaky (stromatic) layers parallel to the bedding and foliation as well as in dilatant zones such as shear-zones or boudin-necks. In other instances the leucosome layers converge laterally or are connected vertically by small extensional shears to give a veined network, termed a diktyonitic structure (Johnson et al., 2001b). Thicker sheets and veins of white to pale-grey leucogranite up to a few metres across containing metasedimentary schollen and ragged and diffuse schlieren are also present, notable on Cable shore west of Cairnbulg Harbour (Figure 37). Generally, the sheets trend near-parallel to the foliation but some do show local discordance. Typically, they have a consistent grain size (1-2 $\mathrm{mm}$ ) and show diffuse margins with the adjacent mesosome, commonly dark coloured and leucosome deficient. The nearby 300 m-thick Cairnbulg 'granite' body shows a much higher degree of leucosome development 
and is best described as a diatexite; only the more-refractory elements of the original parent metasedimentary material remain, forming abundant dispersed 'ghost' schollen and resulting in a nebulitic texture.

Immediately south-east of the Cairnbulg 'granite' is a C. $125 \mathrm{~m}-$ wide zone of veined (diktyonitic) metatexites with an enhanced foliation, in turn bounded to the south-east by a c. 25 m-thick diorite sheet. Psammite with relict spaced cleavage forms enclaves in the migmatitic semipelite section beyond. The enclaves attain some tens of metres thick, e.g. by Gowan Hole (NK 0448 6512) at the east end of Inverallochy.

The boundary of the L-crd and L-gt zones is crossed between Gowan Hole and the Point of Whitelinks at around Broad Hive. It is marked by the incoming of dark purplish red almandine garnets up to $5 \mathrm{~cm}$ across in the white to pale-grey leucosomes; the garnets are commonly retrograded wholly or in part to biotite, chlorite and shimmer aggregate. Good examples are seen on the clean, striated rock platform between Boat Hive and the Point of Whitelinks (Figure 38). Leucosome abundance reflects the original compositional banding in the semipelitic rocks and is commonly focussed around the calcsilicate-rock schollen and smaller pelitic inclusions. Mafic selvidges occur at the margins of some of the plagioclaserich L-gt sheets and veins and they contain mafic schlieren (mainly biotite) and 'ghost' schollen that are manifested as rounded concentrations of now-relict cordierite. In places flame-like L-gt sheets are mingled with L-crd.

On the peninsula between Whitelinks Bay and Millburn Shore (by The Gwights), diatexites with schollen are cut by a thin diorite sheet. To the south-east, at the northern end of Millburn Shore, leucosome of both granitic and granodioritic composition is dominant with abundant dispersed biotite schlieren and schollen of calcsilicate rock and psammite. Rare pelitic and semipelitic 'ghost' enclaves are also present. Sinuous contacts can be recognized between the compositionally different phases of leucosome, but individual garnet porphyroblasts lie across such boundaries showing that the different leucosome melts were coeval. This zone must lie only a short distance above the north-western boundary of the St Combs diorite, which is concealed beneath the sands of Millburn Shore.

The section at St Combs is dominated by two thick diorite sheets, some 100-200 m thick (Figure 35). Sandwiched between them is a large metasedimentary raft consisting of coarse-grained garnet and/or orthopyroxene, cordierite, biotite, quartz and feldspars and containing irregular intergranular leucosome. Johnson et al. (2001b) termed this unit a granoblastic restite. Larger accumulations of leucosome form irregular pods and lenses that in places form centimetre-scale stromatic layers parallel to the regional foliation. Thicker discordant leucosome veins also occur, which Johnson et al. (2001b) interpreted as channelways. Underlying the diorite, to the south-east of Bailiff's Skelly, are melanosome-rich migmatites (leucosome less than 10\%) with a strong foliation and abundant pseudomorphs after orthopyroxene. These dark-green porphyroblasts are up to $3 \mathrm{~cm}$ long and are now composed of green biotite and shimmer aggregate, but still retain their prismatic form and perpendicular cleavages. Cordierite is also 
present and biotite is variably abundant. Leucosome pods here are discontinuous and locally form a fine millimetre-scale stromatic layering. Only relics of the metasedimentary bedding are preserved, notably where psammite beds are present. Leucosome becomes more abundant towards Inzie Head as the migmatites grade from metatexites up to diatexites with a moderate foliation defined by aligned mafic schlieren and semipelitic schollen. Orthopyroxene occurs in the thicker leucosome veins but the thinner ones typically contain cordierite.

Microdiorite and diorite sheets, ranging from some $10 \mathrm{~cm}$ up to 300 $m$ wide, are common throughout the migmatitic sequence and lie subparallel to the regional banding/foliation. They show evidence of only minor deformation and commonly cross-cut the metasedimentary banding and early structures. The diorites consist of essential hornblende, plagioclase and quartz with ilmenite and titanite present. Johnson et al. (2001a) noted that they are similar to uralitized gabbros near Ellon with no trace of clinopyroxene now remaining. Good examples of the relationships between diorite, granite, leucosome and mesosome are seen on Cable Shore, some $200 \mathrm{~m}$ south-west of Cairnbulg pier (Figure 35). Backveining of the granitic leucosome material into the diorite is common and granite-diorite contacts range from sharp to gradational. Leucosome/granite veins penetrate the diorite, commonly forming wispy tongues that invade lobate pillows of diorite. Leucosome is developed preferentially marginal to the diorite sheets, particularly adjacent to their upper margins. In contrast, beneath the diorite sheets the foliation in the migmatitic rocks is intensified and the amounts of leucosome are generally low. The diorite commonly shows evidence of multiple intrusion, with the darker, more-mafic parts of the diorite sheet cross-cutting the earlier paler grey hybridized parts. Within the Cairnbulg 'granite', sheets of diorite show evidence of magma mingling with the leucogranite, which in places is finely porphyritic.

\subsection{Interpretation}

At various times the gneisses of the Cairnbulg-St Combs section have been ascribed to an earlier succession of basement rocks. Read (1955) interpreted them as part of an older Dalradian succession, the 'Keith division', overlain unconformably by younger Dalradian rocks of the 'Banff division' in the Banff Nappe. However, Read and Farquhar (1956) inferred that the migmatization post-dated the metamorphism and that both were superimposed on the Banff Nappe. Sturt et al. (1977) obtained an Rb-Sr whole-rock isochron from gneisses at Cairnbulg Point that gave an age of $691 \pm 39 \mathrm{Ma}$ (674 Ma with currently accepted decay constants). They interpreted this age to date the formation of the migmatitic gneisses and the linked diorite and granite bodies. Ramsay and Sturt (1979) subsequently described a complex multistage tectonic, metamorphic and intrusive history based on detailed field relationships in the gneisses. Accepting the Rb-Sr isochron age, they viewed the lower gneissose rocks as Cadomian basement rocks transported to the North-east Grampian Highlands from elsewhere and inferred that the mid- 
Ordovician Grampian Event was responsible only for the later deformations. However, Rb-Sr isochron ages are dependent on the $\mathrm{Rb}-$ and Sr-bearing minerals in the sample being in isotopic equilibrium and having not been disturbed by subsequent igneous or metamorphic processes or subjected to loss of Sr. The Inzie Head gneisses fail most of these tests and the ages are now regarded as spurious. A clear structural and stratigraphical pattern has now emerged in which all of the dominantly semipelitic gneissose rocks in the North-east Grampian Highlands can be allocated to the Crinan Subgroup in the upper part of the Argyll Group (Kneller, 1987; Stephenson and Gould, 1995; Strachan et al., 2002).

The Inzie Head gneisses lie on the western flank of an antiformal structure that was originally recognized by Grant Wilson (1886) and termed the Ellon Anticline. Read (1923, 1955) renamed this structure the Buchan Anticline and envisaged it as an integral part of the Banff Nappe, reflecting the presence of the migmatitic geissose core of the nappe beneath a resistant 'cap' formed by the Mormond Hill Quartzite. However, as the anticline patently folds both the foliation in the migmatitic rocks and the metamorphic isograds, it is most probably a late-stage Caledonian structure, complementary to the Turriff Syncline to the west (Stephenson and Gould, 1995). Its precise age of formation is not known, but it post-dates the early Ordovician and pre-dates the deposition of the Early Devonian Crovie Group of the Turriff Outlier.

The migmatitic nature of the Inzie Head Gneiss Formation has long been recognized and these rocks represent the acme of the classic high-temperature-low-pressure assemblage characteristic of the Buchan-type metamorphism (see Chinner, 1966; Harte and Hudson, 1979). Further work between 1980 and the present has shown that the high-temperature metamorphism in these rocks was supplemented by heat and an initial fluid input due to the intrusion of a significantly large body of basic magma at shallow depth.

Johnson et al. (2001a, 2001b, 2003) documented the petrography and whole-rock geochemistry of the semipelitic rocks together with the leucosomes and leucogranite sheets from the Inzie Head Gneiss Formation. They concluded that the granitic bodies were formed effectively in situ by melting of the semipelitic host, initially at c. 2.9 kbar and $C .650^{\circ} \mathrm{C}$ with abundant fluid present $\left(a \mathrm{H}_{2} \mathrm{O}=1\right)$. Fluid input was ascribed to dehydration of the metasedimentary rocks resulting from the emplacement of a basic magma accompanied by the formation of shear-zones. The mineral assemblages and nature of the peritectic phases suggest that $\mathrm{P}-\mathrm{T}$ conditions increased south-eastwards to $C .4 .5 \mathrm{kbar}$ and $C .775^{\circ} \mathrm{C}$ such that melting occurred in the absence of a volatile fluid phase. When the normative compositions of the granites are plotted on a quartzalbite-orthoclase diagram they cluster around the minimum-melt compositions at pressure and temperature conditions of c. 3 kbar and over $750^{\circ} \mathrm{C}$, with low $\mathrm{aH}_{2} \mathrm{O}$ (c. 0.3 ) as implied by the mineralogies. The melting reactions largely consume biotite (in addition to quartz and feldspar) in these circumstances.

The nature of the protolith semipelitic and pelitic rocks prior to migmatization and partial melting is not fully known but the mineralogies and geochemistry strongly suggest that they were magnesium-rich aluminous pelitic and semipelitic rocks. Following 
the method of Inger and Harris (1993) Rb vs Sr plots of the pelites, migmatites, leucosomes and leucogranites imply that potash feldspar differentiation (assuming c. 10\% crystallization) has controlled melt composition during its ascent to higher crustal levels. The steeper Rb Vs $\mathrm{Sr}$ trends for the related garnetiferous aplitic veins that are found in the Fraserburgh area suggest that plagioclase feldspar differentiation has controlled melt evolution at a late stage (Johnson et al., 2003).

Johnson et al. (2001b; 2003) suggested that the anatectic melting gave rise initially to melt generation in small patches and vein networks from which the melt then passed upwards into channel ways. The movement of melt material was accompanied by some potash differentiation to give rise to the leucogranites. The rocks seen in the Cairnbulg-St Combs section provide a 'snapshot' of this overall process. Johnson et al. (2003) argued that much of the leucosome is still in situ but their geochemistry also suggests that a variable proportion has moved out of the rocks. Melt has moved to higher levels and some granitic material has certainly moved up from structurally lower levels. The amount of melt produced in the L-crd zone is only possible in the presence of considerable quantities of fluid and Johnson et al. (2001a) argued that fluid supply was enhanced by the formation of numerous shearzones. Quantities of melt seen in the L-gt and L-opx zones are considerably less and are compatible with dry melting reactions.

The proportion of leucosome is greater directly above and below the diorite intrusions, and the metasedimentary rocks beneath show higher concentrations of more-mafic material suggesting that melt has been generated there and migrated upwards. The presence of a gravity and magnetic anomaly suggests that the diorite intrusions are probably related to a mafic-ultramafic intrusion that underlies the area at a very shallow depth and is a member of the midOrdovician North-east Grampian Basic Suite (Johnson et al., 2001b). Figure 36 shows the overall pattern envisaged by Johnson et al. (2001b), whereby they postulated that this process could ultimately have been responsible for the generation of the mid-ordovician granite plutons such as Strichen and Aberdeen. They hypothesized that at the time of emplacement of the North-east Grampian Basic Suite an overlying subhorizontal zone of migmatitic melts would have been generated and that (D2) strain would have been partitioned into such zones giving rise to a network of ductile shear-zones. Field relationships and age dates from the Portsoy and Huntly areas do indeed imply that major shearing, emplacement of the mafic and ultramafic plutons, and formation of migmatitic rocks all occurred in a short episode at around $470 \mathrm{Ma}$ (Strachan et al., 2002; Carty, 2001; Oliver, 2002). The older foliated muscovite-biotite granite plutons were also intruded at about this time.

\subsection{Conclusions}

The Cairnbulg to St Combs coastal section displays a spectacular range of migmatites that developed in Dalradian metasedimentary host rocks during mid-Ordovician (Grampian Event) low-pressure-hightemperature metamorphism. The rocks belong to the Inzie Head 
Gneiss Formation, which consists dominantly of gneissose semipelites, with pelites, psammites and lenticles and bands of calcsilicate rock. Some researchers have ascribed these gneisses to various basement successions, which according to one theory were pre-Dalradian and were transported to the North-east Grampian Highlands from elsewhere. However, later work has rejected the basement hypotheses and has re-affirmed the overall coherence of the Dalradian succession across the area. The Inzie Head gneisses, along with most other gneissose sequences in the North-east Grampian Highlands, are now assigned to the Crinan Subgroup of the Argyll Group.

The gneissose rocks are at the sillimanite grade of metamorphism and show evidence of partial melting, at first in the presence of excess fluid but later in a fluid-absent mode. The granitic material generated (termed the leucosome) pervades the host rocks as pale-grey veins, lenses, streaks, patches and larger irregular bodies. Thicker discordant veins, commonly formed of white to pale-grey leucogranite, are interpreted as channel ways, through which granite that had been mobilized at slightly deeper levels migrated upwards to be 'frozen' in its present position. The leucosome material has resulted from the melting of semipelite and pelite at pressures of 3 to 4.5 kbar (equivalent to $10-14 \mathrm{~km}$ crustal depth) and temperatures of $650-775^{\circ} \mathrm{C}$. Minerals that crystallized in the leucosome at the time of melt formation show zonation of the migmatitic rocks from cordierite- up to garnet- and ultimately orthopyroxene-bearing leucosome. The highest grades are seen around St Combs, where the original bedding of the metasedimentary rocks is preserved in places as a 'ghost stratigraphy'. Only rarely has the accumulation of granitic material been sufficient to result in larger granitic bodies, as for example by Cairnbulg Point. This 'migmatitic granite' contains abundant metasedimentary relics that represent the more-refractory components of the host rock.

Diorite sheets that have been intruded throughout the section show textural and structural relationships with the granitic leucosome, implying that their intrusion coincided with melt generation. The diorite intrusions are probably related to a mafic-ultramafic intrusion that underlies the area at a very shallow depth and belongs to the mid-Ordovician North-east Grampian Basic Suite. If this is the case, it is valuable evidence that the basic suite was emplaced close to the peak of regional metamorphism in the Buchan area.

The migmatization and associated partial melting post-date an earlier penetrative deformation phase but were accompanied by a secondary deformation that generated the overall foliation seen in the migmatitic rocks. The foliation dips moderately to steeply to the north-west, as the outcrops lie on the western flank of a major late-stage antiform termed the Buchan Anticline, which controls the distribution of Dalradian units and folds the metamorphic isograds in the Ellon-Fraserburgh-Peterhead area.

This GCR site clearly has a wide significance in terms of the overall history of the Grampian Event, including the peak of metamorphism and the role of the mafic and ultramafic intrusions of the North-east Grampian Basic Suite. It is also clear that studies 
of the gneisses have been particularly significant to our understanding of the small- and medium-scale processes of migmatite formation and generation of granitic melts from semipelitic and pelitic protoliths. In this they have potential international importance.

\section{COLLIESTON TO WHINNYFOLD (NK $084 \quad 337-\mathrm{NK} 042 \quad 287$ )}

\section{J.R. Mendum}

\subsection{Introduction}

The c. 7 km-long coastal section between Collieston and Whinnyfold, $20 \mathrm{~km}$ south of Peterhead, exposes turbiditic psammites and pelites assigned to the collieston Formation of the Southern Highland Group, which are disposed in a series of recumbent folds. The beds show an abundance of grading from gritty bases to pelitic tops and Bouma sequences can be recognized, albeit generally incomplete. Basic sheets intrude the metasedimentary rocks, mainly as sills but locally as dykes, and a possible tuffaceous unit occurs on the north-east side of Collieston Bay. The grade of metamorphism varies from greenschist facies in the north-east to lower amphibolite facies in the south-west and the section encompasses the andalusite and cordierite isograds. The relatively low metamorphic grade and abundance of grading in the rocks enables the geometry of the early-formed fold structures to be elucidated. The beds form part of a large-scale recumbent syncline that faces eastwards and most of the exposed succession lies on its upper, inverted limb. Evidence for a second deformation episode can be found towards the south-west end of the section.

The area was mapped during the primary geological survey by J.S. Grant Wilson and the resulting one-inch sheet 87 was published in 1885. A brief description of the metamorphic rock types and some of the structures was given in the accompanying memoir (Grant Wilson, 1886). Subsequently, the coastal section was mapped in detail by O.C. Farquhar and a comprehensive summary of the structure was given by Read and Farquhar (1956). The area was revised by the Geological Survey in 1980-81 and an account of the section was given in the excursion guide to the Geology of the Aberdeen area by Mendum (1987). This account is based upon the latter work.

Read (1955) and Read and Farquhar (1956) showed that the Collieston-Whinnyfold section is important in terms of interpreting the overall geology of the North-east Grampian Highlands. They proposed that the rocks here form the hinge-zone of their Banff Nappe, a regional east-facing recumbent anticline whose upper limb crops out in the Banffshire coast section, east of the Boyne Line (see the Cullen to Troup Head GCR site report). They envisaged formation of the Collieston folds by gravitational processes linked to the rise of the open Buchan Anticline farther west. However, it is now clear that the Buchan Anticline, which exposes sillimanite- 
grade gneissose Argyll Group rocks in its broad hinge-zone, is a late-stage structure that refolds the earlier cleavages (see the Cairnbulg to St Combs GCR site report). The Collieston-Whinnyfold section remains anomalous as the only area of the North-east Grampian Highlands that contains a regionally inverted succession and a structural pattern similar to that seen in Southern Highland Group rocks near the Highland Border.

\subsection{Description}

This GCR site consists of coastal cliffs, typically 25-30 m high but in parts reaching 45-50 $\mathrm{m}$, and intertidal foreshore. As the area has been used for inshore fishing over many years the various indentations of the coast have been given names; these are partly topographical, partly historical and in places obviously personal (Figure 39).

The section lies oblique to the strike of the bedding and to the gentle NNE-plunging fold axes. Traversing south-west from Whinnyfold, one moves structurally down but stratigraphically up the section (Figures 39, 40). Recumbent folding on a scale of tens of metres disrupts the simple progression but south-west of old Castle, fold amplitude and wavelength increase to several hundreds of metres. This latter section appears to be part of the hingezone to the large recumbent syncline. From Collieston southwestwards one appears to be traversing out of the hinge-zone and onto the lower limb of the main east-facing syncline; the overall structure becomes more complex and the superimposed secondary deformation and folding become more dominant. Impure metalimestones and calcsilicate bands some $2.5 \mathrm{~km}$ south-west of Collieston, between The Smithy (NK 0262 2658) and Rockend (NK 0215 2668), are possible representatives of the Tayvallich Subgroup. The coast section is described below from north-east to south-west.

At Sandy Haven, $350 \mathrm{~m}$ north-east of Whinnyfold, locally brecciated and hornfelsed psammites and semipelites are cut by the red Peterhead Granite. The contact is sharp, steeply dipping and when traced southwards it is offset in places by small faults. At the south margin of the bay, large xenoliths of grey to olive-green psammite, up to $30 \mathrm{~m}$ wide and $100 \mathrm{~m}$ long, show irregular contacts with the granite. On the headland to the south-east (the cruner) thin- to medium-bedded psammites and semipelites contain gritty bands that show flattened quartz and feldspar clasts. Some boudinage is present and a discrete S1 spaced cleavage is developed (spacing $5 \mathrm{~mm}$ to $13 \mathrm{~mm}$ ).

South-west from Whinnyfold are further grey coarse- and mediumgrained psammites and semipelites with interbeds of fissile cordierite-bearing pelite. In parts thicker pelitic units are present. Calcsilicate lenses are common within the turbiditic succession. Lenticular, fawn-weathering, cream, gritty quartzites with notable quartz veining form discrete units several metres thick within the turbiditic succession. The beds dip at $15^{\circ}$ to $17^{\circ}$ to the north-north-east and excellent grading at NK 08093298 shows that the succession is inverted. Large-scale tight recumbent folds (F1) are present in Buck's Nose Bay and have a variably developed axial-planar spaced cleavage. Well-defined grading and bottom 
structures at the gritty psammite-pelite contacts show that the folds face to the east. Some of the folds north-east of the bay have disharmonic profiles and show discontinuities near parallel to bedding. Similar features occur farther to the south-south-west at Lady's step (NK 0801 3274) where tight S-profile F1 folds with attenuated middle limbs are seen. In these fold-pairs, the syncline is much larger in amplitude than the corresponding anticline, which when traced westwards diminishes to zero. The fold axes are subhorizontal and trend $010^{\circ}$.

Cliffs on the south side of Green Craig Bay, at NK 0684 3154, expose inverted graded beds with cuspate bottom structures trending $142^{\circ}$. In the pelitic units, which here form a greater proportion of the succession, grey andalusite 'slugs' and darker grey, small, rounded cordierite porphyroblasts are abundant. The stack of Green Craig itself shows recumbent $\mathrm{Fl}$ folds underlain by an apparent discontinuity (Read and Farquhar, 1956, plate VI, figure 1). F1 fold hinges are exposed on the foreshore at the southern edge of the bay. Fold axes here plunge very gently to the south-southwest, with the S1 axial-planar cleavage dipping at $18^{\circ}$ to the eastsouth-east. However, the prominent rounded fold hinge in massive gritty psammite units figured by Read and Farquhar (1956, plate IV, figure 2) at this location folds the S1 spaced cleavage and is attributed to the secondary deformation (termed D3). Although this later fold is co-axial with Fl folds, the related axial plane dips at $26^{\circ}$ to the west-north-west. A further sign of this later, D3 deformation is shown by the abundant folded quartz veining in morepelitic units on the north side of the bay, which imply some 58\% shortening.

At the Devil's Study (NK 0606 3091), a spectacular example of a recumbent westward-closing F1 syncline is exposed (Figure 41). It occurs in thick-bedded, locally gritty psammites and subsidiary interbanded cordierite-bearing schistose pelites and semipelites. A prominent $\mathrm{S} 1$ axial-planar spaced cleavage (spacing $C .5 \mathrm{~mm}$ ) is uniformly developed across the fold profile. The lower limb is strongly attenuated and the complementary antiform in the pelitic beds below has a much smaller amplitude. The fold appears to be underlain by a discontinuity. To the south-west, towards Radel Haven, tight folds confined to individual beds are interpreted as slump folds. In addition, the gritty bases of inverted psammite units are exposed on the low foreshore. The dominant quartz and feldspar clasts show little evidence of significant superimposed strain in these thicker psammites, yet the more-elongate clasts show a strong grain alignment that plunges gently to between $340^{\circ}$ and $020^{\circ}$. Grain alignment is also seen on the bases of inverted graded psammite units just north of the Devil's study, where the resultant lineation plunges at $10^{\circ}$ towards $007^{\circ}$. On the north edge of Radel Haven (NK 0584 3083), more-complete Bouma sequences contain both laminated and cross-laminated silty units.

The cliffs below Old Castle (NK 0525 3005) are composed mainly of cordierite-rich schistose semipelite and pelite with coarse andalusite present in parts. Abundant tight Fl folds plunge gently to the north, and are commonly confined to particular stratigraphical intervals. In parts a later s3 crenulation cleavage is also developed. North of the old Castle promontory, 
psammites show a more closely spaced (c. $3 \mathrm{~mm}$ ) $\mathrm{S} 1$ cleavage and in the intertidal zone the $\mathrm{S} 1$ cleavage is folded by minor open to close folds whose axes plunge about $25^{\circ}$ to the north-north-east. A fine-scale spaced S3 cleavage is developed locally. F1+F3 folding is abundantly developed farther south at Portie shore (around NK 0415 2991) involving the lenticular quartzite units. A weakly developed 53 spaced cleavage is widely seen on weathered surfaces in the psammites; it shows a spacing of $15-20 \mathrm{~mm}$. A finely spaced crenulation cleavage in the pelitic units attests to the oncoming of penetrative D3 deformation.

Between Old Castle and Collieston, tight F1 and open to tight F3 folds are particularly abundant. An excellent example of a recumbent fold train in interbedded psammitic and pelitic units is displayed at Pottie Murlan (NK 0478 2916) (Read and Farquhar, 1956, plate IV, figure 1 ). The fold axes plunge at $2^{\circ}$ to $031^{\circ}$ and axial planes dip at $23^{\circ}$ to the east-south-east. Although the fold profile is coherent and individual hinges are complementary to one another, closer inspection shows that there is a combination of F1 and $\mathrm{F} 3$ folds. Hence in some fold hinges the S1 cleavage is axial planar but in others S1 is folded and a new S3 spaced cleavage is developed. In thin section both cleavages are defined by biotite concentrations but individual biotite laths are generally aligned parallel to $\mathrm{S} 3$.

South-west of Pottie Murlan, thin- to medium-bedded psammites and pelitic units show tight F1 and F3 folding but are right way up overall. By Dowiestone Cave, a deformed metadolerite dyke has cuspate margins and shows cleaved biotite amphibolite marginal zones. Several other metadolerite intrusions are seen farther south in the cliffs between Aver Hill and Collieston.

At Collieston, most of the psammite-pelite succession is inverted but tight recumbent $\mathrm{F} 1$ folds are common giving rise to way-up reversals. The quarry face behind the car park on the east side of Tarness Haven displays a c. 10 m-high profile of a recumbent syncline formed in gritty, locally pebbly psammites and subsidiary semipelites and pelites. The fold faces east-south-east, has a pervasive S1 spaced cleavage, and its axis plunges at $16^{\circ}$ to $026^{\circ}$. At the northern end of the quarry, similar pebbly psammites form units up to $4 \mathrm{~m}$ thick and contain ripped-up mud clasts derived from underlying pelitic lithologies. On the rocky slabs above st Catherine's Dub, south-east of the car park, inverted psammites with prominent gritty and pebbly bases show a strong grainalignment lineation. The white to pink quartz clasts are notably elongate and the lineations are curved on some bedding planes and of variable intensity. The lineations plunge gently to moderately to the north-north-east. Their variability and association with a linear fabric in the matrix suggests that here they are dominantly of tectonic origin, and the overall strain patently reflects both D1 and D3 deformation events. In the psammites, minor F3 folds fold the pervasive S1 spaced cleavage and an accompanying S3 spaced cleavage is developed locally. Near the low watermark by the arch at the west side of St Catherine's Dub, tight F1 and F3 folds are abundant in gritty psammites and cordierite-bearing pelites and semipelites. Fl fold axes plunge gently to the north-north-east, co-axial with an L1 lineation, and a discordant S3 cleavage is well 
developed. Discordant quartz veins that post-date F1 folds and S1 cleavage are tightly folded here (F3) .

A 4 m-thick discordant metadolerite sheeet with cuspate margins and small boudinaged offshoots can be traced up the east side of Tarness Haven and across the car park to the gully on the east side of St Catherine's Dub. The marginal alteration to biotite-rich foliated amphibolite is clearly seen.

Near low-water mark on the east side of Tarness Haven, weathered fine-grained, green-brown, ?chlorite-rich units are interbanded with dark-grey, thinly banded cordierite-rich pelites and semipelites over a vertical interval of $1.5 \mathrm{~m}$. These units might represent tuffaceous horizons deposited in more-distal parts of the turbidite fan.

South of Collieston Harbour, coastal outcrops show psammites with excellent non-inverted grading, interbedded with pelites that contain larger cordierite porphyroblasts and some andalusite. D3 deformation generally becomes more penetrative to the south, although the earlier D1 structures are still generally apparent.

\subsection{Interpretation}

The Collieston to Whinnyfold section exposes beds that are assumed to represent the lower part of the Southern Highland Group on the basis of thin impure calcareous beds and quartzites, exposed at the lowest stratigraphical level to the south-west of the GCR site, which could be the sparse representatives of the Tayvallich Subgroup in this area. Read and Farquhar (1956) interpreted these calcareous and quartzose lithologies as part of the Mormond Hill Quartzite, now the Mormond Hill Quartzite Member of the dominantly semipelitic Strichen Formation. They believed that the Mormond Hill Quartzite forms a thick lenticular unit in the core of the Buchan Anticline but the distribution of units strongly implies that there are significant lateral facies variations. Inland bedrock exposures are few on the eastern limb of the anticline, and it is difficult to correlate the stratigraphy with the betterestablished succession on the western limb.

The psammites and pelitic rocks of the Southern Highland Group succession are interpreted as having been deposited on a sub-marine fan by density currents in the late Neoproterozoic. The lenticular quartzose units appear to represent channel fills and might have been produced by reworking of the turbiditic units by bottom currents. Although quartz is the dominant clastic constituent of the succession, locally with a bluish opalescent tint indicative of inclusions, potash feldspar and more rarely plagioclase grains have been recorded (Read and Farquhar, 1956). The matrix consists of sericite, chlorite, altered feldspar and quartz in the low-grade rocks but as metamorphic grade increases biotite, muscovite, feldspar and quartz form a mosaic. Accessory iron-oxide minerals, tourmaline, garnet, zircon and titanite have also been recorded. Retrogression to chlorite and sericite is common locally. The pelitic rocks show more-recrystallized mica fabrics south-west of Bruce's Haven (NK 0680 3144) but cordierite porphyroblasts occur throughout much of the section. These are rounded dark-grey spots, except just south of Collieston Harbour where larger 'black slugs' 
are found. In thin section many are altered to pinite but as grade increases some sector-twinned cordierite is present. Andalusite is paler grey and forms elongate 'slugs'; it is first seen as pseudomorphs around Berry's Loup (NK 0745 3217) but forms coherent porphyroblasts farther south-west with laths up to $6 \mathrm{~cm}$ long recorded south-west of Collieston (Munro, 1986). Both cordierite and andalusite overgrow the S1 fabric and are wrapped and deformed by the 53 fabric, thus placing the peak of metamorphism between the two deformation events.

Structurally the Collieston-Whinnyfold section is important as it shows the nature of the early D1 deformation and makes an interesting comparison with that seen on the Banffshire coast (see the Cullen to Troup Head GCR site report) and near the Highland Border (see the Little Glenshee GCR site report). In the Collieston-Whinnyfold section the F1 folds are recumbent, face eastwards and there are significant stretches of overturned strata. oncoming of the secondary deformation (D3) is gradual but coincides approximately with the andalusite isograd. On the Banffshire coast F1 folds are largely upright and verge and face to the west and the secondary deformation comes on more sharply, again coincident with the andalusite isograd. Fold axes plunge gently northwards in both sections. Development of $\mathrm{S} 1$ spaced cleavage and metamorphic assemblages are also similar.

The F1 fold geometry seen in the Collieston-Whinnyfold section shows some unusual features. Fold profiles are variable along their axial planes and in numerous instances the synclines and anticlines that constitute fold-pairs have disparate amplitudes. Dislocations are also numerous both in fold stacks and beneath folded zones. This geometry suggests that either the turbiditic Southern Highland Group sequence here might not have been fully lithified at the time of deformation or that the mode of deformation was shear dominated with abundant fluids present. However, the related S1 cleavage is uniformly developed and fold axis orientations are relatively consistent, showing that deformation was tectonic and not syn-sedimentary. Although slump or soft-sediment folds seem to be present locally, they are not abundant. As this part of the sequence lies in the lower part of the Southern Highland Group, which is little younger than $600 \mathrm{Ma}$ (Dempster et al., 2002), and the uppermost parts of the group were deposited at about $515 \mathrm{Ma}$, it seems unlikely that the succession would remain unlithified over some $80 \mathrm{Ma}$.

The lack of marker bands in the sequence makes it awkward to construct an accurate cross-section, but Figure 40 shows a projected, composite, down-plunge cross-section that represents an overall structural profile of the exposed section. The orientation data for the section between Whinnyfold and Old Castle, where D3 deformation is not well developed, are shown on the stereoplot (inset to Figure 39). The fold geometry is consistent, whereas farther south-west where D3 deformation is stronger, the F1 and F3 axes show a greater spread.

Read and Farquhar envisaged the Collieston folding to have been initiated as a large recumbent fold, the Banff Nappe, which moved eastwards generating the Buchan Anticline as a 'tectonic drumlin' due to the inclusion of the resistant Mormond Hill quartzite in the 
thrust succession. The folding of the collieston turbiditic succession was attributed to 'gravity sliding' on the steep 'brow of the bulge' formed by the quartzite.

Ashcroft et al. (1984) and Harte et al. (1984) both suggested that the Collieston structure could represent a lateral equivalent of the hinge-zone below the Tay Nappe, albeit with a reduced amplitude. Certainly, the styles of folding and metamorphic conditions resemble those found in the eastern Highland Border region, but the fold facing is to the east rather than south-east. If the Collieston-Whinnyfold rocks do belong to the lower limb of the Tay Nappe, it is interesting to speculate whether the upright F1 folding of the Banffshire coast section was indeed coeval with the recumbent $F 1$ folding at Collieston. It seems clear that the metamorphic peak in the Dalradian rocks in general relates to orogenic events, termed D2, that are not represented by structures in the Collieston-Whinnyfold section, or elsewhere in the Buchan area. The D2 deformation occurred coeval with the intrusion of the mid Ordovician-age North-east Grampian Basic Suite at c. 470 Ma (Strachan et al., 2002). The D1 and D2 deformations were succeeded by a further deformation event and metamorphism, D3, that is represented here by the onset of reworking and enhanced metamorphic grade.

\subsection{Conclusions}

The well-exposed coast section between Collieston and Whinnyfold demonstrates the nature of early folding in the some of the youngest Dalradian rocks seen in the North-east Grampian Highlands. These Collieston Formation beds lie in the lower part of the Southern Highland Group and comprise turbiditic, originally sandy and muddy, psammites, semipelites and pelites. More-quartzose gritty psammites form distinctive lenticular units up to $c$. $10 \mathrm{~m}$ thick in the turbiditic fan succession and probably represent reworked sands within channels. Grading is common and the 'Bouma sequences' that typify turbidite successions can easily be recognized. Groove casts, pebble alignment and rare pebble imbrication at the base of individual units imply that the density currents flowed north, and hence the offshore depositional slope appears to have been towards the north, at least in this area.

The rocks are folded into a large, composite, recumbent syncline. Numerous smaller scale anticlines and synclines have axes that plunge gently to the north and axial planes that dip gently to the north-east. The beds become younger eastwards and hence the folds face east. A penetrative spaced cleavage, defined by mica-rich seams and intervening quartz-rich microlithons, is developed in the psammites and a slaty to schistose cleavage is developed in the pelitic lithologies. Much of the succession lies on the upper, inverted limb of the main syncline, as is shown by the graded bedding. The more-pelitic rocks contain abundant cordierite, and andalusite is present in all but the lower grade north-eastern part of the section. A secondary deformation becomes progressively more important in the south-west. This has resulted in tightening of the early structures and attenuation of the cleavages. However, in 
many parts westward-verging minor folds fold the early cleavage and a new spaced or crenulation cleavage is developed.

The collieston-Whinnyfold folds could represent the most northeasterly exposed extent of the Tay Nappe, although the structure here seems to have reduced amplitude. It remains an area of crucial importance in terms of regional interpretations of the Dalradian structure and sequence and lends itself to further study as well as providing an excellent teaching section.

\section{ACKNOWLEDGEMENTS}

This regional paper is the combined work of 7 authors, many of whom, in addition to their own site descriptions, have made valuable comments on other aspects of the work.

The paper has been compiled and edited by D. Stephenson. The GCR editor was P.H. Banham and the referee was M.R.W. Johnson, who also provided valuable editorial suggestions. The project was cofunded by the Joint Nature Conservation Committee (JNCC) and the British Geological Survey (BGS) and has been managed by N.V. Ellis for JNCC and D.J. Fettes and M. Smith for BGS.

The initial site selection and site documentation for the Dalradian block of the Geological Conservation Review was by S.J. Moorhouse. Since then, much new mapping and refined interpretation has taken place, and the site list has been revised, firstly by J.E. Treagus and subsequently through a panel consisting of $R$. Anderton, A.L. Harris, J.R. Mendum, J.L. Roberts, P.W.G. Tanner, R. Threadgould and J.E. Treagus. The necessary amendments to the GCR documentation were greatly facilitated by R. Wignall (for Scottish Natural Heritage).

K.M. Goodenough and S.W. Horsburgh assisted with preliminary drafts of key maps and all diagrams were drafted for publication by S.C. White (JS Publications, Newmarket) and K.J. Henderson (BGS, Edinburgh). Photographs were scanned and prepared by B.M. McIntyre (BGS, Edinburgh). Photographs from the BGS collection are reproduced by kind permission of the Director, BGS ( Natural Environment Research Council; all rights reserved (PR/23-27).

Several of the principal authors of the Dalradian GCR have been involved in the writing of other reviews of the Dalradian of Scotland and, inevitably, sections of introductory text have been adapted and updated from their contributions to those earlier works. In particular, large sections have been adapted from British Regional Geology: the Grampian Highlands (Stephenson and Gould, 1995) and some smaller sections have been adapted from a chapter in The Geology of Scotland (Strachan et al., 2002) and from a recent review of the evolution of the north-east margin of Laurentia (Leslie et al., 2008). The original sources of many key diagrams taken from these and other works are acknowledged in their captions.

The first complete draft of the Dalradian GCR was submitted to the JNCC in June 2009. In 2010, the JNCC terminated its involvement in Earth Science conservation and abandoned its contractual agreements to publish the remaining GCR volumes. So, the authors are greatly indebted to Diarmad Campbell, Chief Geologist Scotland for the BGS, 
for funding the drafting of remaining figures and to the Geologists' Association and Elsevier, for ensuring that this volume is published as a special Issue of their Proceedings. We are particularly grateful to Neil Ellis of the JNCC for his efforts to secure a new publisher and to Professor James Rose, Editor in Chief of the PGA, for making it all happen.

Finally, on behalf of all of the site authors, we would like to record our thanks to the owners and managers of land and quarries who have allowed access to the sites, either during previous work or specifically for the GCR exercise.

\section{REFERENCES}

Agrell, S. O. (1942) 1. A petrological investigation of the adinoles at Dinas Head, Cornwall. 2. A petrofabric study of the Ben Vuroch granite and the adjacent schists in Perthshire. Unpublished PhD thesis, University of Cambridge.

Ahmed-Said Y. and Tanner P. W. G. (2000) P-T conditions during emplacement, and D2 regional metamorphism, of the Ben Vuirich Granite, Perthshire, Scotland. Mineralogical Magazine, 64, 737-53.

Ague, J.J. \& Baxter, E.F., 2007. Brief thermal pulses during mountain building recorded by $\mathrm{Sr}$ diffusion in apatite and multicomponent diffusion in garnet. Earth and Planetary Science Letters, 261, 500-516.

Allen, J. R. L. 1963. The classification of cross stratified units with notes on their origin. Sedimentology, 2, pp. 93-114.

Allison, A. (1933) The Dalradian succession in Islay and Jura. Quarterly Journal of the Geological Society, London, 89, 125-44.

Allison, A. 1941. Loch Awe succession and tectonics-KilmartinTayvallich-Danna. Quarterly Journal of the Geological Society, London, 96, 423-49.

Allison, I., May, F and Strachan, R.A. (1988) An Excursion guide to the Moine Geology of the Scottish Highlands. Scottish Academic Press for Edinburgh Geological Society and Geological Society of Glasgow.

Alsop, G.I. and Hutton, D.H.W. (1990) A review and revision of Dalradian stratigraphy in central and southern Donegal, Ireland. Irish Journal of Earth Sciences, 10, 181-98.

Alsop, G.I., Prave, A.R., Condon, D.J. and Phillips, C.A. (2000) Cleaved clasts in Dalradian conglomerates: possible evidence for Neoproterozoic compressional tectonism in Scotland and Ireland? Geological Journal, 35, 87-98.

Amos, B.J. (1960). The geology of the Bowmore district, Islay. Unpublished PhD thesis, University of London, Imperial College.

Anderson, E M. (1923). The geology of the schists of the Schiehallion district. Quarterly Journal of the Geological Society of London, 79, 423-45.

Anderson, E M. (1951) The Dynamics of Faulting. (Second edition). (Edinburgh: Oliver and Boyd.)

Anderson, J. G. C., (1942) The stratigraphical order of the Dalradian schists near the Highland Border in Angus and Kincardineshire. Transactions of the Geological Society of Glasgow, 20, 223-37.

Anderson, J.G.C. (1947a) The geology of the Highland Border, Stonehaven to Arran. Transactions of the Royal Society of Edinburgh, 61, 479-515. 
Anderson, J.G.C. (1947b) The Kinlochlaggan Syncline, southern Inverness-shire. Transactions of the Geological Society of Glasgow, 21, 97-115.

Anderson, J.G.C. (1948) Stratigraphic nomenclature of Scottish metamorphic rocks. Geological Magazine, 85, 89-96.

Anderson, J.G.C (1956). The Moinian and Dalradian rocks between Glen Roy and the Monadhliath Mountains, Inverness-shire. Transactions of the Royal Society of Edinburgh, 63, 15-36.

Anderton, R. (1974) Middle Dalradian sedimentation in Argyll, with particular reference to the Jura quartzite, Scarba conglomerate and Craignish phyllites. Unpublished PhD thesis, University of Reading.

Anderton, R. (1975) Tidal flat and shallow marine sediments from the Craignish Phyllites, Middle Dalradian, Argyll, Scotland. Geological Magazine, 112, 337-40.

Anderton, R. (1976) Tidal-shelf sedimentation: an example from the Scottish Dalradian. Sedimentology, 23, 429-58.

Anderton, R. (1977) The Dalradian rocks of Jura. Scottish Journal of Geology, 13, 135-42.

Anderton, R. (1979) Slopes, submarine fans and syn-depositional sedimentology of parts of the Middle and Upper Dalradian in the S.W. Highlands of Scotland. In The British Caledonides - Reviewed (eds. Harris, A. L., Holland, C. H. and Leake, B. E.), Geological Society, London, Special Publications, 8.

Anderton, R. (1980). Distinctive pebbles as indicators of Dalradian provenance. Scottish Journal of Geology, 16, 143-52.

Anderton, R. (1982) Dalradian deposition and the late Precambrian Cambrian history of the $\mathrm{N}$ Atlantic region: a review of the early evolution of the Iapetus ocean. Journal of the Geological Society of London, 139, 421-31.

Anderton, R. (1985) Sedimentation and tectonics in the Scottish Dalradian. Scottish Journal of Geology, 21, 407-36.

Anderton, R. (1988) Dalradian slides and basin development: a radical interpretation of stratigraphy and structure in the SW and Central Highlands of Scotland. Journal of the Geological Society of London, 145, 669-78.

Arndt, N.T. and Nisbet, E.G. (editors) (1982) Komatiites. George Allen and Unwin, London.

Ashcroft W.A., Kneller B.C., Leslie, A.G. and Munro M. (1984) Major shear zones and autochthonous Dalradian in the northeast Scottish Caledonides. Nature, London 310, 760-2.

Ashworth, J.R. (1972) Migmatites of the Huntly-Portsoy area, northeast Scotland. Unpublished PhD thesis, University of Cambridge.

Ashworth, J.R. (1975) The sillimanite zones of the Huntly-Portsoy area in the north-east Dalradian, Scotland. Geological Magazine, $112,113-224$.

Ashworth, J.R. (1976) Petrogenesis of migmatites in the HuntlyPortsoy area, north-east Scotland. Mineralogical Magazine, 40, $661-82$.

Ashworth, J.R. (1979) Comparative petrography of deformed and undeformed migmatites from the Grampian Highlands of Scotland. Geological Magazine, 116, 445-56.

Astin, T.R. and Rogers, D.A. (1991) 'Subaqueous shrinkage cracks' in the Devonian of Scotland re-interpreted. Journal of Sedimentary Petrology, 61, 850-9.

Atherton, M.P. (1977) The metamorphism of the Dalradian rocks of Scotland. Scottish Journal of Geology, 13, 331-70. 
Atherton, M.P., and Brotherton, M.S. (1972) The composition of some kyanite-bearing regionally-metamorphosed rocks from the Dalradian. Scottish Journal of Geology, 8, 203-13.

Atherton, M.P. and Ghani, A.A. (2002) Slab breakoff: a model for Caledonian, Late Granite syn-collisional magmatism in the orthotectonic (metamorphic) zone of Scotland and Donegal. Lithos, 62, $65-85$.

Bailey, E.B. (1910) Recumbent folds in the schists of the Scottish Highlands. Quarterly Journal of the Geological Society of London, $66,586-620$.

Bailey, E. B. 1913. The Loch Awe Syncline (Argyllshire). Quarterly Journal of the Geological Society of London, 69, 280-307.

Bailey, E.B. (1917) The Islay anticline (Inner Hebrides). Quarterly Journal of the Geological Society of London, 72, 132-64.

Bailey, E.B. (1922) The structure of the South West Highlands of Scotland. Quarterly Journal of the Geological Society of London, 78, 82-131.

Bailey, E.B. (1925) Perthshire tectonics: Loch Tummel, Blair Atholl and Glen Shee. Transactions of the Royal Society of Edinburgh, 53, 671-98.

Bailey, E.B. (1930) New Light on Sedimentation and Tectonics. Geological Magazine, 67, 77.

Bailey, E.B. (1934) West Highland tectonics: Loch Leven to Glen Roy. Quarterly Journal of the Geological Society of London, 90, $462-523$.

Bailey, E.B. (1938) Eddies in mountain structure. Quarterly Journal of the Geological Society of London, 94, 607-25.

Bailey, E B. (1953). Facies changes versus sliding: Loch Leven, Argyll. Geological Magazine, 90, 111-13.

Bailey, E.B. (1960) The geology of Ben Nevis and Glencoe and the surrounding country. (2nd edition). Memoir of the Geological Survey of Great Britain, Sheet 53 (Scotland).

Bailey, E.B., and McCallien, W. (1937). Perthshire tectonics: Schiehallion to Glen Lyon. Transactions of the Royal society of Edinburgh, 59, 79-118.

Bailey, E B, and MacGregor, M. 1912. The Glen Orchy Anticline, Argyllshire. Quarterly Journal of the Geological Society of London, Vol. 68, 164-179.

Bailey, E.B., and Maufe, H.B. (1916) The geology of Ben Nevis and Glen coe and the surrounding country. (1st edition). Memoir of the Geological Survey of Great Britain, Sheet 53 (Scotland).

Bain, J.A., Briggs, D.A. and May, F. (1971) Geology and mineralogical appraisal of an extensive talc-magnesite deposit in the Shetlands. Transactions of the Institute of Mining and Metallurgy, $\mathbf{8 0}, \mathrm{B} 77-\mathrm{B} 84$.

Baker, A.J. (1985) Pressures and temperatures of metamorphism in the eastern Dalradian. Journal of the Geological society of London, 142, 137-48.

Baker, A.J. (1987) Models for the tectonothermal evolution of the eastern Dalradian of Scotland. Journal of Metamorphic Geology, 5, 101-18.

Baker, A.J., and Droop, G.T.R. (1983) Grampian metamorphic conditions deduced from mafic granulites and sillimanite-Kfeldspar gneisses in the Dalradian of Glen Muick, Scotland. Journal of the Geological Society of London, 140, 489-97. 
Baldwin, C.T. and Johnson, H.D. (1977) The Dalradian rocks of Lunga, Luing and Shuna. Scottish Journal of Geology, 13, 143-54.

Banks, C. J. (2005). Neoproterozoic Basin Analysis: a combined sedimentological and provenance study in the Grampian Group, Central Highlands, Scotland. Unpublished PhD Thesis, University of Keele.

Banks, C.J. (2007) Exceptional preservation of sedimentary structures in metamorphic rocks: an example from the upper Grampian Group, Creag Stalcair, Perthshire. Scottish Journal of Geology, 43, 9-14.

Banks, C.J. and J.A. Winchester (2004). Sedimentology and stratigraphic affinities of Neoproterozoic coarse clastic successions, Glenshirra Group, Inverness-shire Scotland. Scottish Journal of Geology 40, 159-174.

Banks, C.J., Smith, M., Winchester, J.A., Horstwood, M.S.A., Noble, S.R. and Ottley, C.J. (2007) Provenance of intra-Rodinian basinfills: the lower Dalradian Supergroup, Scotland. Precambrian Research, 153, 46-64.

Barreiro, B.A. (1998) U-Pb systematics on zircon from the Keith and Portsoy granites, Grampian Highlands, Scotland. NERC Isotope Geosciences Laboratory Report Series No. 132.

Barrow, G. (1893) On an intrusion of muscovite-biotite gneiss in the south-east Highlands of scotland, and its accompanying metamorphism. Quarterly Journal of the Geological Society of London, 49, 330-58.

Barrow, G. (1904) Moine gneisses of the east central Highlands and their position in the Highland sequence. Quarterly Journal of the Geological Society of London, 60, 400-44.

Barrow, G. (1912) On the geology of Lower Deeside and the southern Highland border. Proceedings of the Geologists' Association, 23, 274-90.

Barrow G. and Cunningham Craig E.H. (1912) The geology of the districts of Braemar, Ballater and Glen Clova. Memoir of the Geological Survey of Great Britain, Sheet 65 (Scotland).

Barrow, G, Grant Wilson, J S, and Cunningham Craig, E H. (1905). The geology of the country around Blair Atholl, Pitlochry and Aberfeldy. Memoir of the Geological Survey of Great Britain, Sheet 55 (Scotland).

Basahel, A.N. (1971) The Dalradian stratigraphy and structure of southern Islay, Argyll. Unpublished PhD thesis. University of Liverpool.

Batchelor, R.A. (2011) Geochemistry of Torridonian tuffs and contemporary phosphorites; potential for correlation of Torridonian sequences in NW Scotland. Scottish Journal of Geology, 47, 133-142.

Baxter, E.F., Ague, J.J. and Depaolo, D.J. (2002) Prograde temperature-time evolution in the Barrovian type-locality constrained by Sm/Nd garnet ages from Glen Clova, Scotland. Journal of the Geological Society, London, 159, 71-82.

Beddoe-Stephens B. (1990) Pressures and temperatures of Dalradian metamorphism and the andalusite-kyanite transformation in the northeast Grampians. Scottish Journal of Geology 26, 3-14.

Bell, A. M. (1981) Vergence: an evaluation. Journal of Structural Geology, Volume 3, 197-202.

Bendall, C.A. (1995). A geochronological, structural and metamorphic study of rocks from the central and SW Dalradian of Scotland. Unpublished PhD thesis, University of Manchester 
Bentley, M.R. (1986) The tectonics of Colonsay, Scotland. Unpublished PhD thesis, University of Wales, Aberystwyth.

Bentley, M.R. (1988). The Colonsay Group. In Winchester, J.A (ed.) Later Proterozoic stratigraphy of the Northern Altlantic Regions. Blackie and Son Ltd., London, 119-30.

Bentley, M.R., Maltman, A.J., and Fitches, W.R. (1988) Colonsay and Islay: a suspect terrane within the Scottish Caledonides. Geology, 16, 26-8.

Bingen B., Demaiffe D. and van Breemen O. (1998) The 616 Ma old Egersund basaltic dyke swarm, SW Norway, and late Neoproterozoic opening of the Iapetus Ocean. Journal of Geology, 106, 565-74.

Bingen, B., Griffin, W.L. Torsvik, T.H. and Saeed, A. (2005) Timing of late Neoproterozoic glaciation on Baltica constrained by detrital zircon geochronology in the Hedmark Group, south-east Norway. Terra Nova, 17, 250-58.

Bliss, G.M. (1977) The micropalaeontology of the Dalradian. Unpublished PhD thesis, University of London, Imperial College.

Bluck, B.J. (1983) Role of the Midland Valley of Scotland in the Caledonian Orogeny. Transactions of the Royal Society of Edinburgh: Earth Sciences, 74, 119 -136.

Bluck, B.J. (1984) Pre-Carboniferous history of the Midland Valley of Scotland. Transactions of the Royal Society of Edinburgh: Earth Sciences, 75, 275-95.

Bluck, B.J. (2000) 'Where ignorance is bliss 'tis a folly to be wise' (Thomas Gray 1716-1761) - controversy in the basement blocks of Scotland. Scottish Journal of Geology, 36, 97-101.

Bluck, B.J. (2001) Caledonian and related events in Scotland. Transactions of the Royal Society of Edinburgh: Earth Sciences, 91, 375-404.

Bluck, B.J. (2002) The Midland Valley Terrane. In: Trewin, N.H. (ed.) The Geology of Scotland. The Geological Society, London, $149-66$.

Bluck, B.J. (2010) The Highland Boundary Fault and the Highland Boundary Complex. Scottish Journal of Geology, 46, 113-124.

Bluck B.J. and Dempster T.J. (1991) Exotic metamorphic terranes in the Caledonides: tectonic history of the Dalradian block, Scotland. Geology, 19, 1133-6.

Bluck B.J., Dempster T.J., and Rogers G. (1997) Allochthonous metamorphic blocks on the Hebridean passive margin, Scotland. Journal of the Geological Society of London 154, 921-4.

Bluck, B.J., Gibbons, W. and Ingham, J.K. (1992). Terranes. 1-4 in Atlas of palaeogeography and lithofacies. Cope, J.C.W., Ingham, J.K., and Rawson, P.F. (editors). Geological Society of London Memoir, No. 13.

Bluck B.J., Halliday A. N., Aftalion M., and Macintyre R.M. (1980) Age and origin of the Ballantrae ophiolite and its significance to the Caledonian orogeny and Ordovician time scale. Geology 8, 49295 .

Bluck, B.J. and Ingham, J.K. (1997) The Highland Border controversy: a discussion of "New evidence that the Lower Cambrian Leny Limestone at Callander, Perthshire belongs to the Dalradian Supergroup, and a reassessment of the 'exotic' status of the Highland Border Complex". Geological Magazine, 134, 563-70.

Bluck B.J., Ingham J.K., Curry G.B., and Williams A. (1984) The significance of a reliable age from some Highland Border rocks in Central Scotland. Journal of the Geological Society of London 139, 451-4. 
Boersma, J.R. (1969) Internal structures of some tidal megaripples on a shoal in the Westerschelde estuary, the Netherlands. Geologie on Mijnbouw, 48, 409-14.

Booth, J.E. (1984) Structural, stratigraphic and metamorphic studies in the SE Dalradian Highlands. Unpublished PhD thesis. University of Edinburgh.

Borradaile, G.J. (1970) The west limb of the Loch Awe syncline and the associated cleavage fan. Geological Magazine, 107, 459-467.

Borradaile, G.J. (1972a) The structural and stratigraphic history of the Dalradian rocks of the Northern Loch Awe syncline, Argyllshire. Unpublished PhD thesis, University of Liverpool.

Borradaile, G.J. (1972b) Variably oriented co-planar primary folds. Geological Magazine, 190, 89-98.

Borradaile, G. J. (1973) Dalradian structure and stratigraphy of the northern Loch Awe district, Argyllshire. Transactions of the Royal Society of Edinburgh, 69, 1-21.

Borradaile, G.J. (1974). Bulk finite strain estimates from the deformation of Neptunian dykes. Tectonophysics, 22, 127-39.

Borradaile, G.J. (1977) The Dalradian rocks of the northern Loch Awe district. Scottish Journal of Geology, 13, 155-64.

Borradaile, G.J. (1979). Pre-tectonic reconstruction of the Islay anticline: implications for the depositional history of Dalradian rocks in the SW Highlands. In The Caledonides of the British Isles-reviewed. Harris, A L, Holland, C H, and Leake, B E (editors). Special Publication of the Geological society of London, No. 8, pp. 229-38.

Borradaile, G.J. and Johnson, H.D. (1973) Finite strain estimates from the Dalradian Dolomitic Formation, Islay, Argyll, Scotland. Tectonophysics, 18, 249-59.

Boué, A. (1820) Essai Géologique sur l'Écosse. Ve Courcier, Paris.

Bouma, A. H. (1962). Sedimentology of some Flysch Deposits, a Graphic Approach to Facies Interpretation. Elsevier Co. Amsterdam, $168 \mathrm{pp}$.

Bowden, A.J. (2007) Book review: MacCulloch's 1840 Geological Map of Scotland. Scottish Journal of Geology, 43, 181-4.

Bowes, D.R. and Convery, H.J.E. (1966) The composition of some Ben Ledi grits and its bearing on the origin of albite schists in the south-west Highlands. Scottish Journal of Geology, 2, 67-75.

Bowes, D.R. and Wright, A.E. (1967) The explosion breccia pipes near Kentallen, Scotland and their geological setting. Transactions of the Royal Society of Edinburgh, 67, 109-43.

Bowes, D.R. and Wright, A.E. (1973) Early phases of Caledonian deformation in the Dalradian of the Ballachulish district, Argyll. Geological Journal, 8, 333-44.

Bowring, S., Myrow, P., Landing, E., Ramezani, J. and Grotzinger, J. (2003) Geochronological constraints on Terminal Neoproterozoic events and the rise of metazoans. Geophysical Research Abstracts 5, p13219.

Bradbury, H.J. (1978) Stratigraphic, structural, igneous and metamorphic history of the Dalradian rocks of the Ben Vrackie-Ben Vuirich district, Tayside, Scotland. Unpublished PhD thesis, University of Liverpool.

Bradbury, H.J. (1979) Migmatization, deformation and porphyroblast growth in the Dalradian of Tayside, Scotland. In The Caledonides of the British Isles - Reviewed Harris, A.L., Holland, C.H. and Leake, B.E. (eds). Geological Society, London, Special Publications, 8, 351-6. 
Bradbury, H.J. (1985) The Caledonian metamorphic core: an Alpine model. Journal of the Geological Society of London, 142, 129-36.

Bradbury, H.J., and Harris, A.L. (1982) Low grade Dalradian sediments carrying spaced cleavage; Polyphase deformation of spaced cleavage. In Atlas of deformational and metamorphic rock fabrics. Borradaile, G J, Bayly, M B, and Powell, C McA (editors). Springer Verlag, Berlin, pp. 100-9.

Bradbury, H.J., Harris, A.L. and Smith, R.A. (1979). Geometry and emplacement of nappes in the Central Scottish Highlands. In The Caledonides of the British Isles - reviewed. (eds. Harris, A.L., Holland, C.H. and Leake, B.E.), Special Publication of the Geological Society of London, 8, 213-20.

Bradbury H.J., Smith R.A. and Harris A.L. (1976) 'Older' granites as time-markers in Dalradian evolution. Journal of the Geological Society, London, 132, 677-84.

Brasier, M.D., Ingham, J.K. and Rushton, A.W.A. (1992) Cambrian. 13-18 in Atlas of Palaeogeography and Lithofacies. Cope, J.C.W., Ingham, J.K. and Rawson, P. F. (editors). Memoirs of the Geological Society, London, 13.

Brasier, M.D. and Mcilroy, D. (1998) Neonereites uniserialis from c. $600 \mathrm{Ma}$ year old rocks in western Scotland and the emergence of animals. Journal of the Geological Society, London, 155, 5-12.

Brasier, M.D. and Shields, G. (2000) Neoproterozoic chemostratigraphy and correlation of the Port Askaig glaciation, Dalradian Supergroup of Scotland. Journal of the Geological Society, London, 157, 909-14.

Brasier, M.D., McCarron, G., Tucker, R., Leather, J., Allen, P. and Shields, G. (2000) New U-Pb zircon dates for the Neoproterozoic Ghubrah glacaiation and for the top of the Huqf Supergroup, Oman. Geology, 28, 175-8.

Briden, J.C., Turnell, H.B. and Watts, D.R. (1984) British palaeomagnetism, Iapetus Ocean and the Great Glen Fault. Geology $12,136-9$.

Burgess J.G, Graham, C.M. and Harte, B. (1981). Kyanite and chloritoid phyllites from the chlorite zone of the Scottish Highlands. Journal of the Geological Society of London, 138, $p$. 634 (abstract).

Burt, C.E. (2002) Sedimentary environments and basin evolution of the upper Dalradian: Tayvallich Subgroup and Southern Highland Group. Unpublished PhD thesis, Kingston University.

Burton, C.J., Hocken, C., MacCallum, D. and Young, M.E. 1983. Chitinozoa and the age of the Margie Limestone of the North Esk. Proceedings of the Geological Society of Glasgow Vol. 124-125, 2732 .

Cannat M. (1989) Late Caledonian northeastward ophiolite thrusting in the Shetland Islands, U.K. Tectonophysics 169, 257-70.

Canning J.C., Henney P.J., Morrison M.A. and Gaskarth J.W. (1996) Geochemistry of late Caledonian minettes from northern Britain: implications for the Caledonian sub-continental lithospheric mantle. Mineralogical Magazine 60, 221-36.

Canning, J.C., Henney, P.J., Morrison, M.A., Van Calsteren, P.W.C., Gaskarth, J.W. and Swarbrick, A. (1998) The Great Glen Fault: a major vertical lithospheric boundary. Journal of the Geological Society, London, 155, 425-8. 
Carty, J.P. (2001) Deformation, metamorphism, magmatism and fluidflow in the Portsoy Shear Zone, N.E. Scotland. Unpublished PhD thesis, University of Derby.

Cawood, P.A., McCausland, P.J.A. and Dunning, G.R. (2001) Opening Iapetus: constraints from the Laurentian margin in Newfoundland. Geological Society of America Bulletin, 113, 443-53.

Cawood, P.A., Nemchin, A.A., Smith, M. and Loewy, S. (2003). Source of the Dalradian Supergroup constrained by U-Pb dating of detrital zircon and implications for the East Laurentian margin. Journal of the Geological Society of London 160, 231-46.

Cawood, P.A., Nemchin, A.A., Strachan, R.A., Prave, A.R. and Krabbendam, M. (2007) Sedimentary basin and detrital zircon record along East Laurentia and Baltica during assembly and breakup of Rodinia. Journal of the Geological Society, London, 164, 257-75.

Chew, D.M. (2001) Basement protrusion origin of serpentinite in the Dalradian. Irish Journal of Earth Science, 19, 23-35.

Chew, D.M., Daly, J.S., Magna, T., Page, L.M., Kirkland, C.L., Whitehouse, M.J. and Lam, R. (2010) Timing of ophiolite obduction in the Grampian orogen. Geological Society of America Bulletin, 122, 1787-1799.

Chew, D.M., Fallon, N., Kennelly, C., Crowley, Q. and Pointon, (2009) Basic volcanism contemporaneous with the Sturtian glacial episode in NE Scotland. Earth and Environmental Science Transactions of the Royal Society of Edinburgh, 100, 399-415

Chew, D.M., Graham, J.R. and Whitehouse, M.J. (2007) U-Pb zircon geochronology of plagiogranites from the Lough Nafooey (= Midland Valley) arc in western Ireland: constraints on the onset of the Grampian orogeny. Journal of the Geological Society, London Vol. $164,747-50$.

Chinner, G.A. (1957) The metamorphic history of the Glen Clova district, Angus. Unpublished PhD Thesis, University of Cambridge.

Chinner, G.A. (1960) Pelitic gneisses with varying ferrous/ferric ratios from Glen Clova, Angus, Scotland. Journal of Petrology, 1, $178-217$.

Chinner, G.A. (1961) The origin of sillimanite in Glen Clova, Angus. Journal of Petrology Vol. 2, 312-23.

Chinner, G.A. (1966) The distribution of pressure and temperature during Dalradian metamorphism. Quarterly Journal of the Geological Society of London, 122, 159-86.

Chinner, G.A. (1978) Metamorphic zones and fault displacement in the Scottish Highlands. Geological Magazine, Vol. 115, 37-45.

Chinner, G.A. and Heseltine, F.J. (1979) The Grampian andalusite/kyanite isograd. Scottish Journal of Geology, Vol. 15, $117-127$.

Coats, J.S., Pease, S.F. and Gallagher, M.J. (1984) Exploration of the Scottish Dalradian. 21-34 in Prospecting in areas of glaciated terrain. (London: Institution of Mining and Metallurgy.)

Coats, J.S., Smith, C.G., Gallagher, M.J., May, F., Fortey, N.J. and Parker, M.E. (1978) Stratabound barium-zinc mineralisation in Dalradian schist near Aberfeldy, Scotland: preliminary report. Institute of Geological Sciences, Mineral Reconnaisance Programme Report No. 26.

Coats, J.S., Smith, C.G., Fortey, N.J., Gallagher, M.J., May, F. and McCourt, W.J. (1980) Stratabound barium-zinc mineralization in Dalradian schist near Aberfeldy. Transactions of the Institution of Mining and Metallurgy (Section B: Applied Earth Science), 89, $110-22$. 
Coats, J.S., Smith, C.G., Gallagher, M.J., May, F., McCourt, W.J., Parker, M.E. and Fortey, N.J. (1981) Stratabound barium-zinc mineralisation in Dalradian schist near Aberfeldy, Scotland: final report. Institute of Geological Sciences, Mineral Reconnaissance Programme Report No. 40.

Collerson, K.D., Jesseau, C.W. and Bridgewater, D. (1976). Contrasting types of bladed olivine in ultramafic rocks from the Archaean of Labrador. Canadian Journal of Earth Sciences, 13, 44250 .

Collinson, J. (1994). Sedimentary deformational structures. pp. 95125 In Maltman, A. (ed.). The geological deformation of sediments. Chapman and Hall.

Collinson, J.D. and Thompson, D.B. 1988. Sedimentary Structures. George Allen and Unwin, London. 207 pp.

Condon, D.J. and Prave, A.R. (2000). Two from Donegal: Neoproterozoic glacial episodes on the northeast margin of Laurentia. Geology, 28, 951-4.

Cooper, M.R. and Johnston, T.P. (2004) Central Highlands (Grampian) Terrane. 9-24, in: Mitchell, W.I. (editor), The Geology of Northern Ireland-Our Natural Foundation (2nd edition). Geological Survey of Northern Ireland, Belfast.

Coward, M.P. (1983) The thrust and shear zones of the Moine Thrust Zone of NW Scotland. Journal of the Geological Society of London $140,795-811$.

Coward, M.P. (1990) The Precambrian, Caledonian and Variscan framework to NW Europe. In Tectonic Events Responsible for Britain's Oil and Gas Reserves. Hardman, R.F.P. and Brooks, J. (eds) Geological Society, London, Special Publications, 55, 1-34.

Craig G. Y., McIntyre D. B., and Waterston C. D. (1978) James Hutton's Theory of the Earth: the lost drawings. Scottish Academic Press, Edinburgh.

Crane A., Goodman S., Krabbendam M., Leslie A. G., Paterson I. B., Robertson S. And Rollin K. E. (2002) Geology of the Glen Shee District. Memoir of the British Geological Survey. Sheet 56W with parts of sheets 55E, 65W and 64E (Scotland).

Cummins, W.A. and Shackleton, R.M. (1955) The Ben Lui recumbent syncline. Geological Magazine, 92, 353-62.

Cunningham Craig, E.H. (1904) Metamorphism in the Loch-Lomond District. Quarterly Journal of the Geological Society, London, 60, $10-31$.

Cunningham Craig, E.H. (2000) (written 1901). Explanation of Sheet 38 (Loch Lomond). Selected documents from the BGS Archives No 3. British Geological Survey Technical Report No. wo/00/05.

Cunningham Craig, E.H., Wright, W.B. and Bailey, E.B. (1911) The Geology of Colonsay and Oronsay with parts of Ross of Mull. Memoir of the Geological Survey of Scotland, Sheet 35 (Scotland).

Curry, G.B., Bluck, B.J., Burton, C.J., Ingham, J.K., Siveter, D.J. And Williams, A. (1984) Age, evolution and tectonic history of the Highland Border Complex, Scotland. Transactions of the Royal Society of Edinburgh: Earth Sciences, 75, 113-33.

Cutts, K.A., Hand, M., Kelsey, D.E. and Strachan, R.A. (2011) P-T constraints and timing of Barrovian metamorphism in the Shetland Islands, Scottish Caledonides: implications for the structural setting of the Unst ophiolite. Journal of the Geological Society, 168, 1265-1284. 
Dallmeyer, R.D., Strachan, R.A., Rogers, G., Watt, G.R. and Friend, C.R.L. (2001) Dating deformation and cooling in the Caledonian thrust nappes of north sutherland, Scotland: insights from 40Ar/39Ar and Rb-Sr chronology. Journal of the Geological Society of London 158, 501-12.

Daly, J.S., Muir, R.J. and Cliff, R.A. (1991) A precise U-Pb zircon age for the Inishtrahull syenitic gneiss, County Donegal, Ireland. Journal of the Geological Society, London, 148, 639-42.

Dalziel, I.W.D. (1994) Precambrian Scotland as a Laurentia-Gondwana link: Origin and significance of cratonic promontories. Geology, $22,589-92$.

Dalziel, I.W.D. (1997) Neoproterozoic-Paleozoic geography and tectonics; review, hypothesis, environmental speculation. Geological Society of America Bulletin 109(1), 16-42.

Davidek, K., Landing, E., Bowring, S.A., Westrop, S.R., Rushton, S.A., Fortey, R.A. And Adrain, J. (1998) New Uppermost Cambrian U$\mathrm{Pb}$ date from Avalonian Wales and age of the Cambrian-Ordovician boundary. Geological Magazine, 135, 303-09.

Deer, W.A., Howie, R.A. and Zussman, J. (1992). An Introduction to the Rock Forming Minerals, 2nd ed. Longman Scientific and Technical, London.

Dempster, T.J. (1983) Studies of orogenic evolution in the Scottish Dalradian. Unpublished PhD thesis, University of Edinburgh.

Dempster, T.J. (1985a) Uplift patterns and orogenic evolution in the Scottish Dalradian. Journal of the Geological society of London, 142, 111-128.

Dempster, T.J. (1985b) Garnet zoning and metamorphism of the Barrovian type. Contributions to Mineralogy and Petrology, 89, 308 .

Dempster T.J. and Bluck B.J. (1991) The age and tectonic significance of the Bute amphibolite, Highland Border Complex, Scotland. Geological Magazine 128, 77-80.

Dempster, T.J. and Harte, B. (1986) Polymetamorphism in the Dalradian of the Central Scottish Highlands. Geological Magazine, Vol. 123, 95-104.

Dempster, T.J., Hudson, N.F. and Rogers, G. (1995). Metamorphism and cooling of the NE Dalradian. Journal of the Geological Society, London, 152, 383-90.

Dempster, T.J., Rogers, G., Tanner, P.W.G., Bluck, B.J., Muir, R.J., Redwood, S.D., Ireland, T.R. and Paterson, B.A. (2002) Timing of deposition, orogenesis and glaciation within the Dalradian rocks of Scotland: constraints from U-Pb zircon ages. Journal of the Geological Society, London, 159, 83-94.

Dewey, H. and Flett, J.S. (1911) On some British pillow lavas and the rocks associated with them. Geological Magazine, 8, 202-9, $240-8$.

Dewey J. F. (1969) Evolution of the Appalchian/Caledonian orogen. Nature, London 222, 124-9.

Dewey, J.F. (2005) Orogeny can be very short. Proceedings of the National Academy of Sciences, USA Vol. 102, 15286-93.

Dewey, J.F. and Mange, M. (1999) Petrography of Ordovician and Silurian sediments in the western Irish Caledonides: tracers of a short-lived Ordovician continent-arc collision orogeny and the evolution of the Laurentian Appalachian-Caledonian margin. In: Continental Tectonics (edited by MacNiocaill, C. and Ryan, P. D.). Geological Society, London, Special Publication, 164, 55-107. 
Dewey, J.F. and Pankhurst, R.J. (1970) The evolution of the Scottish Caledonides in relation to their radiometric age pattern. Transactions of the Royal Society of Edinburgh, 68, 361-89.

Dewey, J.F. and Ryan, P.D. (1990) The Ordovician evolution of the South Mayo Trough, Western Ireland. Tectonics, 9, 887-903.

Dewey J.F. and Shackleton R.M. (1984) A model for the evolution of the Grampian tract in the early Caledonides and Appalachians. Nature, London 312, 115-21.

Dewey, J.F. and Strachan, R.A. (2003) Changing Silurian-Devonian relative plate motion in the Caledonides; sinistral transpression to sinistral transtension. Journal of the Geological Society, London, 160, 219-229.

Dickin, A.P. (1992). Evidence for an Early Proterozoic crustal province in the North Atlantic region. Journal of the Geological Society, London, 149, 483-6.

Dickin, A.P., and Bowes, D.R. (1991) Isotopic evidence for the extent of the early Proterozoic basement of Scotland and northwest Ireland. Geological Magazine, 128, 385-8.

Droop, G.T.R. (1987). A general equation for estimating $\mathrm{Fe}^{3+}$ concentrations in ferromagnesian silicates or oxides from microprobe analysis using stoichiometric criteria. Mineralogical Magazine, 51, 431-55.

Droop G.T.R. and Charnley N. (1985) Comparative geobarometry of pelitic hornfelses associated with the Newer Gabbros: a preliminary study. Journal of the Geological Society of London $142,53-62$.

Droop, G.T.R., Clemens, J.D. and Dalrymple, D.J. (2003) Processes and conditions during contact anatexis, melt escape and restite formation: the Huntley Gabbro complex, NE Scotland. Journal of Petrology Vol. 44, 995-1029.

Donovan, R.N. and Foster, R.J. (1972). Subaqueous shrinkage cracks from the Caithness Flagstone Series (Middle Devonian) of northeast Scotland. Journal of Sedimentary Petrology, 42, 309-17.

Downie, C. (1975) The Precambrian of the British Isles: Palaeontology. In A Correlation of Precambrian Rocks in the British Isles (eds. Harris, A.L., Shackleton, R.M., Watson, J.V., Downie, C., Harland, W.B. and Moorbath, S.). Special Report of the Geological Society of London, No. 6. Pp. 113-15

Downie, C. (1984) Acritarchs in British stratigraphy. Special Report of the Geological Society of London, No. 17.

Downie, C., Lister, T.R., Harris, A.L. and Fettes, D.J. (1971) A palynological investigation of the Dalradian rocks of Scotland. Report of the Institute of Geological Sciences, No. $71 / 9$.

Dymoke, P.L. (1989) Geochronological and petrological studies of the thermal evolution of the Dalradian, South-west Scottish Highlands. Unpublished PhD thesis, University of Edinburgh.

Eby G. N. (1992) Chemical subdivision of the A-type granitoids: petrogenetic and tectonic implications. Geology, 20, 641-4.

Edwards, M.B. (1986) Glacial Environments. 416-436 in: Sedimentary Environments and facies (Editor: H.G. Reading). Blackwell Scientific

Publications.

Elles, G.L. (1926) The geological structure of Ben Lawers and Meall Corranaich (Perthshire). Quarterly Journal of the Geological Society of London, 82, 304-31. 
Elles, G.L. (1931) Notes on the Portsoy coastal district. Geological Magazine, 68, 24-34.

Elles, G.L. (1935) The Loch na Cille Boulder Bed and its place in the Highland succession. Quarterly Journal of the Geological Society of London, 91, 111-49.

Elles, G.L. and Tilley, C.E. (1930) Metamorphism in relation to structure in the Scottish Highlands. Transactions of the Royal Society of Edinburgh, 56, 621-46.

Ellis, D.J. and Green, D.H. (1979) An experimental study of the effect of $\mathrm{Ca}$ upon garnet-clinopyroxene Fe-Mg exchange equilibria. Contributions to Mineralogy and Petrology, 71, 13-22.

Ellis, N.V., Bowen, D.Q., Campbell, S., Knill, J.L., McKirdy, A.P., Prosser, C.D., Vincent, M.A. and Wilson, R.C.L. (1996) An Introduction to the Geological Conservation Review. Joint Nature Conservation Committee, Peterborough.

Emery, M. (2005) Polyorogenic history of the Moine rocks of Glen Urquhart, Inverness-shire. Unpublished PhD thesis, University of Portsmouth.

Evans, J.A., Fitches, W.R. and Muir, R.J. (1998) Laurentian Clasts in a Neoproterozic Tilite in Scotland. Journal of Geology, 106, 361-9.

Evans, J.A, and Soper, N.J. (1997) Discussion on metamorphism and cooling of the $\mathrm{NE}$ Dalradian and $\mathrm{U}-\mathrm{Pb}$ and Rb-Sr geochronology of magmatism and metamorphism in the Dalradian of Connemara, western Ireland. Journal of the Geological Society, London, 154, 357-60.

Evans, R.H.S. and Tanner, P.W.G. (1996). A late Vendian age for the Kinlochlaggan Boulder Bed (Dalradian)? Journal of the Geological Society, London, 153, 823-6.

Evans, R.H.S. and Tanner, P.W.G. (1997). Discussion on a late Vendian age for the Kinlochlaggan Boulder Bed (Dalradian): reply. Journal of the Geological Society, London, 154, 917-19.

Eyles, C.H. (1988) Glacially - and tidally - influenced shallow marine sedimentation of the Late Precambrian Port Askaig Formation, Scotland. Palaeogeography, Palaeoclimatology, Palaeoecology, 68, 1-25.

Eyles, C.H. and Eyles, N. (1983) Glaciomarine model for upper Precambrian diamictiles of the Port Askaig Formation, Scotland. Geology, 11, 692-6.

Eyles, N. and Clark, M. (1985) Gravity-induced soft-sediment deformation in glaciomarine sequences of the upper Proterozoic Port Askaig Formation, Scotland. Sedimentology, 32, 789-814.

Fairchild, I.J. (1977) Phengite spherules from the Dalradian Bonnahaven Formation, Islay, Scotland: Glauconitized microfossils. Geological Magazine, 114, 355-64.

Fairchild, I.F. (1980a) Sedimentation and origin of a Late Precambrian "dolomite" from Scotland. Journal of Sedimentary Petrology, 50, 423-46.

Fairchild, I.J. (1980b) Stages in a Precambrian dolomitization, Scotland: Cementing versus replacement textures. Sedimentology, $27,631-50$.

Fairchild, I.J. (1980c) The structure of NE Islay. Scottish Journal of Geology, 16, 189-97.

Fairchild, I.J. (1985) Comment on 'Glaciomarine model for Upper Precambrian diamictiles of the Port Askaig Formation, Scotland'. Geology, 13, 89-90. 
Fairchild, I.J. (1985) Petrography and carbonate chemistry of some Dalradian dolomitic metasediments: preservation of diagenetic textures. Journal of the Geological Society, London, 142, 167-85.

Fairchild, I.J. (1989) Dolomitic stromatolite-bearing units with storm deposits from the Vendian of East Greenland and Scotland: a case of facies equivalence. In Caledonian and related Geology of Scandinavia (ed. Gayer, R. A.), pp. Graham and Trotman, London, pp. 275-283.

Fairchild, I.J. (1991) Itinerary II: Topmost Islay Limestone (Appin Group), Port Askaig and Bonahaven Formations (Argyll Group) Port Askaig area, Islay. In The Late Precambrian geology of the Scottish Highlands and Islands (ed. Lister, C.J.) Geologists' Association Guide No. 44, pp. 33-41.

Fairchild, I.J. (1993) Balmy shores and icy wastes: the paradox of carbonates associated with glacial deposits in Neoproterozoic times. Sedimentology Review, 1, 1-16.

Ferry, J.M. and Spear, F.S. (1978) Experimental calibration of the partitioning of $\mathrm{Fe}$ and $\mathrm{Mg}$ between biotite and garnet. Contributions to Mineralogy and Petrology, 66, 113-17.

Fettes, D.J., (1968). Metamorphic structures of Dalradian rocks in North East Scotland. Unpublished PhD thesis, University of Edinburgh.

Fettes, D.J. (1970) The structural and metamorphic state of the Dalradian rocks and their bearing on the age of emplacement of the basic sheet. Scottish Journal of Geology, Vol. 6, 108-118.

Fettes, D.J. (1971) Relation of cleavage and metamorphism in the Macduff Slates. Scottish Journal of Geology, 7, 248-53.

Fettes, D.J. (1979) A metamorphic map of the British and Irish Caledonides. In: Harris, A.L., Holland, C.H. and Leake, B.E. (eds) The Caledonides of the British Isles-Reviewed. Geological Society, London, Special Publications, 8, 307-21.

Fettes, D.J. and Desmons, J. (editors) (2007) Metamorphic Rocks: a Classification and Glossary of Terms. Recommendations of the International Union of Geological Sciences Subcommission on the Systematics of Metamorphic Rocks. Cambridge University Press, Cambridge

Fettes, D.J., Graham, C.M., Harte, B., and Plant, J.A. (1986a) Lineaments and basement domains; an alternative view of Dalradian evolution. Journal of the Geological Society of London, 143, 453-64.

Fettes, D.J., Graham, C.M., Sassi, F.P., and Scolari, A. (1976) The lateral spacing of potassic white micas and facies series variations across the Caledonides. Scottish Journal of Geology, $12,227-36$.

Fettes, D.J., Harris, A.L. and Hall, L.M. (1986b) The Caledonian geology of the Scottish Highlands. In Synthesis of the Caledonian rocks of Britain. Proceedings of the NATO Advanced Study Institute. Fettes, D J, and Harris, A L (editors). Reidel Dordrecht, pp. 303-34.

Fettes, D.J., Leslie A.G., Stephenson D., and Kimbell S.F. (1991) Disruption of Dalradian stratigraphy along the Portsoy Lineament from new geological and magnetic surveys. Scottish Journal of Geology 27, 57-73.

Fettes, D.J., Long, C.B., Bevins, R.E., Max, M.D., Oliver, G.J.H., Primmer, T.J., Thomas, L.J. and Yardley, B.W.D., 1985. Grade and time of metamorphism in the Caledonide Orogen of Britain and Ireland. . 5 In, Harris, A.L.(ed), The Nature and Timing of 
Orogenic Activity in the Caledonian Rocks of the British Isles. Memoir of the Geological Society, London, 9.

Fettes, D.J., Macdonald, R., Fitton, J.G., Stephenson, D. and Cooper, M.R. (2011) Geochemical evolution of Dalradian metavolcanic rocks: implications for the break-up of the Rodinia supercontinent. Journal of the Geological Society, 168, 1133-1146.

Fisk, S. (1986) An oxygen isotope study of siliceous rocks associated with stratabound mineralisation in scotland and Ireland. Unpublished PhD thesis, University of Strathclyde.

Fitches, W. R. And Maltman, A. J. (1984) Tectonic development and stratigraphy of the western margin of the Caledonides: Islay and Colonsay, Scotland. Transactions of the Royal Society of Edinburgh, 75, 365-82.

Fitches, W.R., Muir, R.J., Maltman, A.J. and Bentley, M.R. (1990) Is the Colonsay-west Islay block of SW Scotland an allochthonous terrane? Evidence from Dalradian tillite clasts. Journal of the Geological Society, London, 147, 417-20.

Fitches, W.R., Pearce, J.A., Evans, J.A. and Muir, R.J. (1996) Provenance of the late Proterozoic Dalradian tillite clasts, Inner Hebrides, Scotland. In Precambrian Crustal Evolution in the North Atlantic Region (ed. Brewer, T. S.), pp. 367-77.

Flinn, D., (1953) Regional metamorphism and migmatisation in Delting, Shetland. Unpublished PhD thesis, University of London, Imperial College.

Flinn, D. (1954) on the time relations between regional metamorphism amd permeation in Delting, Shetland. Quarterly Journal of the Geological Society of London, 110, 177-99.

Flinn, D. (1961) Continuation of the Great Glen Fault beyond the Moray Firth. Nature, London, 191, 589-91.

Flinn, D. (1967) The metamorphic rocks of the southern part of the Mainland of Shetland. Geological Journal, 5, 251-90.

Flinn, D. (1985) The Caledonides of Shetland. In Gee, D. G. and Sturt, B. A. (editors) The Caledonide Orogen-Scandinavia and Related Areas. John Wiley and Sons, Chichester. 1161-72.

Flinn, D. (1995) Formation of gneisses of migmatite and diatexite appearance in Yell, shetland by solid-state grain growth recrystallisation. Geological Journal, 30, 415-22.

Flinn, D. (1999) The Shetland Ophiolite. 31-33, 36-58 In Stephenson et al. (editors) Caledonian Igneous Rocks of Great Britain. Geological Conservation Review Series, No. 17. Joint Nature Conservation Committee, Peterborough, UK.

Flinn, D. (2001) The basic rocks of the Shetland Ophiolite Complex and their bearing on its genesis. Scottish Journal of Geology, 37, $79-96$.

Flinn, D. (2007) The Dalradian rocks of Shetland and their implications for the plate tectonics of the northern Iapetus. Scottish Journal of Geology, Vol. 43, 125-42.

Flinn, D. in press. Geology of Unst and Fetlar in Shetland. Memoir of the British Geological Survey, sheet 131 (Scotland).

Flinn, D. and Moffat, D. T. 1985. A peridotitic komatiite from the Dalradian of Shetland. Geological Journal, 20, 287-292.

Flinn, D. and Moffat, D.T. (1986) A reply to R. W. Nesbitt and L. A. Hartmann. Geological Journal, 21, 207-9.

Flinn, D. and Pringle, I.R. (1976). Age of migmatisation in the Dalradian of Shetland. Nature, London, 259, 299-300.

Flinn, D., Frank, P.L., Brook, M. and Pringle, I.R. (1979) Basement-cover relations in Shetland. In The Caledonides of the 
British Isles-reviewed. Harris, A.L., Holland, C.H. and Leake, B.E. (eds), Geological Society of London special Publication No. $8, \quad 109-15$.

Flinn, D., May, F., Roberts, J.L. and Treagus, J.E. (1972). A revision of the stratigraphic succession of the East Mainland of Shetland. Scottish Journal of Geology, 8, 335-343.

Flinn, D., Miller, J.A. and Roddam, D. (1991) The age of the Norwick hornblendic schists of Unst and Fetlar and the obduction of the Shetland ophiolite. Scottish Journal of Geology 27, 11-19.

Flinn, D. and Oglethorpe, R.J.D. (2005). A history of the Shetland Ophiolite Complex. Scottish Journal of Geology, 41, $141-8$.

Fortey, N.J., Coats, J.S., Gallagher, M.J., Greenwood, P.G. and Smith, C.G. (1993) Dalradian stratabound baryte and base metals near Braemar, NE Scotland. Transactions of the Institution of Mining and Metallurgy (Section B: Applied Earth Science), Vol. $102, \mathrm{~B} 55-64$.

Fortey, N.J. and Smith, C.G. (1986). Stratabound mineralisation in Dalradian rocks near Tyndrum, Perthshire. Scottish Journal of Geology, 22, 377-93.

France, D.S. (1971) Structure and metamorphism of Moine and Dalradian rocks in the Grampians of Scotland near Beinn Dorain between Tyndrum and Moor of Rannoch. Unpublished PhD thesis, University of Liverpool.

Francis, E.H. (1982). Magma and sediment-1: Emplacement mechanisms of late Carboniferous tholeitic sils in Northern Britain. Journal of the Geological Society, London, 139, 1-20.

Friedrich, A.M, Hodges, K.V., Bowring, S.A. and Martin, M.W. (1999) Geochronological constraints on the magmatic, metamorphic and thermal evolution of the Connemara Caledonides, western Ireland. Journal of the Geological Society, London, 156, 1217-30.

Friend, C.R.L., Kinny, P.D., Rogers, G., Strachan, R.A. and Patterson, B.A. (1997) U-Pb zircon geochronological evidence for Neoproterozoic events in the Glenfinnan Group (Moine Supergroup): the formation of the Ardgour granite gneiss, north-west Scotland. Contributions to Mineralogy and Petrology 128, 101-13.

Friend, C.R.L., Strachan, R.A., Kinny, P.D. and Watt, G.R. (2003) Provenance of the Moine Supergroup of NW Scotland; evidence from geochronology of detrital and inherited zircons from (meta)sedimentary rocks, granites and migmatites. Journal of the Geological Society, London 160, $247-57$.

Gallagher, M.J., Smith, C.G., Coats, J.S., Greenwood, P.G., Chacksfield, B.C., Fortey, N.J. and Nancarrow, P.H.A. (1989) Stratabound barium and base-metal mineralisation in Middle Dalradian metasediments near Braemar, Scotland. British Geological Survey, Mineral Reconnaisance Programme Report, No. 104.

Ganguly, J. (1979) Garnet and clinopyroxene solid solutions, and geothermometry based on Fe-Mg distribution coefficient. Geochemica and Cosmochemica Acta 43, 1021-9.

Garson, M.S, and Plant, J. (1973) Alpine Type Ultramafic Rocks and Episodic Mountain Building in the Scottish Highlands. Nature Physical Science, 242, 34-8.

Geikie, A. (1865) The scenery of Scotland viewed in connection with its physical geology with a geological map by sir Roderick I. Murchison and Archibald Geikie). Macmillan, London and Cambridge.

Geikie, A. (1897) Annual report of the Geological Survey of the United Kingdom and of the Museum of Practical Geology for the year 
ending December 31, 1896. In Appendix E from the 44th Report of the Department of Science and Art. (London: Her Majesty's Stationery Office.)

Gibbons, W. And Harris, A.L. (1994) A Revised Correlation of Precambrian rocks in the British Isles. Special Reports, Geological Society, London, 22.

Gillen, C. (1987) Huntly, Elgin and Lossiemouth. 149-160 in Excursion Guide to the Geology of the Aberdeen area. (editors N.H.Trewin, B.C. Kneller, and C. Gillen,). (Edinburgh: Scottish Academic press for Geological Society of Aberdeen).

Gillespie, M.R. and Styles, M.T. (1999). BGS rock classification scheme, Volume 1: Classification of igneous rocks, 2nd edition. British Geological Survey Research Report, RR/99/6

Glover, B.W. (1989). The sedimentology and basin evolution of the Grampian Group. Unpublished PhD Thesis. University of Keele.

Glover, B.W. (1993). The sedimentology of the Neoproterozoic Grampian Group and the significance of the Fort William Slide between Spean Bridge and Rubha Cuilcheanna, Inverness-shire. Scottish Journal of Geology, 29, 29-43.

Glover, B.W. (1998). Sedimentology and lateral extent of the Glenshirra succession, Monadhliath Mountains, Scotland. British Geological Survey Technical Report, WA/98/23.

Glover B.W., Key, R.M., May, F., Clark, G.C., Phillips, E.R. and Chacksfield, B.C. (1995). A Neoproterozoic multi-phase rift sequence: the Grampian and Appin groups of the southwestern Monadhliath Mountains of Scotland. Journal of the Geological Society of London, 152, 391-406.

Glover B.W. and McKie, T. (1996). A sequence stratigraphical approach to the understanding of basin history in orogenic Neoproterozoic successions: an example from the central Highlands of Scotland. In: Sequence stratigraphy in British Geology (eds. Hesselbo, S.P. and Parkinson, D.N. ). Geological Society of London, Special Publication, 103, 257-69.

Glover, B.W. and Winchester, J.A. (1989) The Grampian Group: a major Late Proterozoic clastic sequence in the central Highlands of Scotland. Journal of the Geological Society, London, 146, 8597.

Goodman, S (1991) The Pannanich Hill Complex and the origin of the Crinan Subgroup migmatites in the North-eastern and Central Highlands. Scottish Journal of Geology, 27, 147-56.

Goodman, S. (1994) The Portsoy-Duchray Hill Lineament; a review of the evidence. Geological Magazine 131, 407-15.

Goodman, S., Crane, A., Krabbendam, M. and Leslie, A.G. (1997) Correlation of lithostratigraphic sequences in a structurally complex area: Gleann Fearnach to Glen Shee, Scotland. Transactions of the Royal Society of Edinburgh, 87, 503-13.

Goodman, S, and Lappin, M.A. (1996) The thermal aureole of the Lochnagar Complex: mineral reactions and implications from thermal modelling. Scottish Journal of Geology, 27, 159-72.

Goodman, S., Leslie, A.G., Ashcroft, W.A. and Crane, A. (1990) The geology of the central part of Sheet 65E (Ballater); contribution to the memoir. British Geological Survey Technical Report No. WA $/ 90 / 59$.

Goodman, S. and Winchester, J.A. (1993) Geochemical variations within metavolcanic rocks of the Dalradian Farragon Beds and adjacent formations. Scottish Journal of Geology, 29, 131-41. 
Gorokhov, M., Siedlecka, A., Roberts, D., Melnikov, N.N. and Turchenko, T.L. (2001) Rb-Sr dating of diagenetic illite in Neoproterozoic shales, Varanger Peninsula, northern Norway. Geological Magazine, 138, 541-62.

Gould, D. (1997) The geology of the country around Inverurie and Alford. Memoir of the British Geological Survey, sheets 76E and 76W (Scotland).

Gould, D. (2001) Geology of the Aboyne district. Memoir of the British Geological Survey, sheet 66W (Scotland).

Gower, P.J. (1973) The Middle-Upper Dalradian Boundary with special reference to the Loch Tay Limestone. Unpublished PhD thesis, University of Liverpool.

Gower, P.J. (1977) The Dalradian rocks of the west coast of the Tayvallich peninsula. Scottish Journal of Geology, 13, 125-33.

Gradstein, F.M., Ogg, J.G., and Smith, A.G., Agterberg, F.P., Bleeker, W., Cooper, R.A., Davydov, V., Gibbard, P., Hinnov, L.A., House, M.R., Lourens, L., Luterbacher, H.P., McArthur, J., Melchin, M.J., Robb, L.J., Shergold, J., Villeneuve, M., Wardlaw, B.R., Ali, J., Brinkhuis, H., Hilgen, F.J., Hooker, J., Howarth, R.J., Knoll, A.H., Laskar, J., Monechi, S., Plumb, K.A., Powell, J., Raffi, I., Röhl, U., Sadler, P., Sanfilippo, A., Schmitz, B., Shackleton, N.J., Shields, G.A., Strauss, H., Van Dam, J., van Kolfschoten, T., Veizer, J., and Wilson, D. (2004) A Geologic Time Scale 2004. Cambridge University Press, 589 pp.

Graham, C.M. (1976) Petrochemistry and tectonic significance of Dalradian metabasaltic rocks of the SW Scottish Highlands. Journal of the Geological Society, London, 132, 61-84.

Graham, C.M. (1983). High-pressure greenschist to epidoteamphibolite facies metamorphism of the Dalradian rocks of the $\mathrm{SW}$ Scottish Highlands. Geological Society Newsletter, 12, No. 4, 19.

Graham, C.M. (1986) The role of the Cruachan Lineament during Dalradian evolution. Scottish Journal of Geology, 22, 257-70.

Graham, C.M. and Borradaile, G.J. (1984). The petrology and structure of Dalradian metabasic dykes of Jura: implications for Dalradian evolution. Scottish Journal of Geology, 20, 257-70. Same page range as previous ref?

Graham, C.M. and Bradbury, H.J. (1981) Cambrian and late Precambrian basaltic igneous activity in the Scottish Dalradian: a review. Geological Magazine, 118, 27-37.

Graham, C.M., Greig, K.M., Sheppard, S.M.F. and Turi, B. (1983) Genesis and mobility of the $\mathrm{H}_{2} \mathrm{O}-\mathrm{CO}_{2}$ fluid phase during regional greenschist and epidote amphibolite facies metamorphism: a petrological and stable isotope study in the Scottish Dalradian. Journal of the Geological Society, London, 140, 577-599.

Graham, C.M. and Harte, B. (1985) Conditions of Dalradian metamorphism. Journal of the Geological Society, London, 142, 1-3.

Grant Wilson, J.S. (1882) Explanation of Sheet 97. Northern Aberdeenshire, Eastern Banffshire. Memoir of the Geological Survey, Scotland.

Grant Wilson, J.S. (1886) Explanation of Sheet 87, North-east Aberdeenshire and detached portions of Banffshire. Memoir of the Geological Survey, Scotland.

Grant Wilson, J.S., and Hinxman, L.W. (1890) Geology of central Aberdeenshire. Memoir of the Geological Survey of Scotland, Sheet 76 (Scotland). 
Green, J.F.N. (1924) The structure of the Bowmore-Portaskaig District of Islay. Quarterly Journal of the Geological Society, London, 80, $72-105$.

Green, J.F.N. (1931) The South-west Highland Sequence. Quarterly Journal of the Geological Society of London 87, 513-550.

Gregory, J.W. (1910) Work for Glasgow geologists-the problems of the South-western Highlands. Transactions of the Geological Society of Glasgow 14, 1-29.

Gregory, J.W. (1916) Pre-Cambrian of Scotland. Handbuch der Regionaler Geologie, III, Part I, 34-42.

Gregory, J.W. (1928) The geology of Loch Lomond. Transactions of the Geological society of Glasgow 18, 301-23.

Gregory, J.W. (1929) The Pre-Cambrian or Pre-Palaeozoic of Scotland. 28-42 in Evans, J. W. and Stubblefield, C. J. (editors) Handbook of the geology of Great Britain. Murby.

Gregory, J.W. (1930) The sequence in Islay and Jura. Transactions of the Geological Society of Glasgow Vol. 18, 420-441.

Gregory, J.W. (1931) Dalradian Geology: The Dalradian Rocks of Scotland and their Equivalents in other Countries. Methuen, London.

Greig, K.M., (1987) Metamorphosed carbonates and fluid behaviour in the Dalradian of S.W. Argyll, Scotland. Unpublished PhD thesis, University of Edinburgh

Grieve, A. (1996) Ruskin and Millais at Glenfinlas. The Burlington Magazine, 138, 228-234.

Gunn, A.G., Styles, M.T., Stephenson, D., Shaw, M.H. and Rollin, K. (1990) Platinum-group elements in ultramafic rocks of the Upper Deveron Valley, near Huntly, Aberdeenshire. Mineral Reconnaissance Programme Report, British Geological Survey, No. 115.

Gunn, W., Clough, C.T. and Hill, J.B. (1897) The Geology of Cowal, including the part of Argyllshire between the Clyde and Loch Fyne. Memoirs of the Geological Survey of Scotland, Sheets 29, 37 and 38 .

Hackman, B.D. and Knill, J.L. (1962) Calcareous algae from the Dalradian of Islay. Palaeontology, 5, 268-71.

Hall, A.J. (1993) Stratiform mineralisation in the Dalradian of Scotland. In Mineralisation in the British Isles. Pattrick, R.A.D., and Polya, D.A. (editors). Chapman and Hall, London, pp. 38-101.

Hall, J., Brewer, J.A., Matthews, D.H. and Warner, M. (1984) Crustal structure across the Caledonides from the WINCH seismic reflection profile: Influences on the evolution of the Midland Valley of Scotland. Transactions of the Royal Society of Edinburgh: Earth Sciences, 75, 97-109.

Halliday, A.N., Graham, C.M., Aftalion, M. and Dymoke, P. (1989) The depositional age of the Dalradian Supergroup: $\mathrm{U}-\mathrm{Pb}$ and $\mathrm{Sm}-\mathrm{Nd}$ isotopic studies of the Tayvallich Volcanics, Scotland. Journal of the Geological Society, London, 146, 3-6.

Hambrey, M.J. (1983) Correlation of the Late Proterozoic tillites in the North Atlantic region and Europe. Geological Magazine, 120, 209-32.

Hambrey, M.J. and Harland, W.B. (editors). (1981) Earth's prePleistocene glacial record. Cambridge University Press, Cambridge. 
Hambrey, M.J. and Harland, W.B. (1985) The Late Proterozoic glacial era. Palaeogeography, Palaeoclimatology and Palaeoecology, 51, 255-72.

Hambrey, M.J. and Waddams, P. (1981) Glaciogenic boulder-bearing deposits in the Upper Dalradian Macduff Slates, northeastern scotland. In Earth's pre-Pleistocene glacial record. Hambrey, M.J. and Harland, W.B. (editors). Cambridge University Press, Cambridge, pp. 571-5.

Harkness, R. (1861) On the rocks of the portions of the Highlands of Scotland south of the Caledonian Canal; and on their equivalents in the north of Ireland. Quarterly Journal of the Geological Society of London 17, 256-71.

Harris, A.L. (1960) Dalradian geology of an area between Pitlochry and Blair Atholl. Unpublished PhD thesis, University of Wales, Aberystwyth.

Harris, A.L. (1962) Dalradian geology of the Highland Border, near Callander. Bulletin of the Geological Survey of Great Britain, 19, $1-15$.

Harris, A.L. (1963). Structural investigations in the Dalradian rocks between Pitlochry and Blair Atholl. Transactions of the Edinburgh Geological Society, 19, 256-278.

Harris, A.L. (1969) The relationships of the Leny Limestone to the Dalradian. Scottish Journal of Geology, 5, 187-90.

Harris, A.L. (1972) The Dalradian rocks at Dunkeld, Perthshire. Bulletin of the Geological Survey of Great Britain, 38, 1-10.

Harris, A.L. (1995) Nature and timing of orogenesis in the Scottish Highlands and the role of the Great Glen Fault. In Current perspectives in the Appalachian-Caledonian Orogen, Hibbard, J., van Stall, C.R. and Cawood, P.A. (editors) Geological Association of Canada, Special Paper 41, 65-79.

Harris, A.L., Baldwin, C.T., Bradbury, H.J., Johnson, H.D. and Smith, R.A. (1978) Ensialic basin sedimentation: the Dalradian Supergroup. In Crustal evolution in northwestern Britain, Bowes, D R, and Leake, B E (editors) Special Issue of the Geological Journal No. 10 . Seel House Press, Liverpool, pp. 115-38

Harris, A.L., and Bradbury, H.J. (1977) Discussion of 'The evolution and transport of the Tay Nappe'. Scottish Journal of Geology, 13, 81-3.

Harris, A.L., Bradbury, H.J. and McGonigal, N.H. (1976) The evolution and transport of the Tay Nappe. Scottish Journal of Geology, 12, 103-13.

Harris, A.L. And Fettes, D.J. (1972) Stratigraphy and structure of Upper Dalradian rocks at the Highland Border. Scottish Journal of Geology, 8, 253-64.

Harris, A.L., Fettes, D.J. And Soper, N.J. (1998a) Age of the Grampian event: a Discussion of "New evidence that the Lower Cambrian Leny Limestone at Callander, Perthshire, belongs to the Dalradian Supergroup, and a re-assessment of the "exotic" status of the Highland Border Complex". Geological Magazine, 135, 575.

Harris, A.L., Haselock, P.J., Kennedy, M.J., Mendum, J.R., Long, J.A., Winchester, J.A. and Tanner, P.W.G. (1994). The Dalradian Supergroup in Scotland, Shetland, and Ireland, In A Revised Correlation of the Precambrian Rocks of the British Isles (eds. W. Gibbons and A.L. Harris), Geological Society, London, Special Report No. 22, 33-53. 
Harris, A.L., Parson, L.M., Highton, A.J. and Smith, D.I. 1981. New/Old Moine relationships between Fort Augustus and Inverness (Abstract). Journal of Structural Geology, 3, 187-88.

Harris, A.L. and Pitcher, W.S. (1975) The Dalradian Supergroup. In A Correlation of Precambrian Rocks in the British Isles. (eds. Harris, A. L., Shackleton, R. M., Watson, J.V., Downie, C., Harland, W. B. and Moorbath, S.), Special Reports of the Geological Society, London, 6, pp. 52-75.

Harte, B. (1966) Stratigraphy, structure and metamorphism in the south-eastern Grampian Highlands of Scotland. Unpublished PhD thesis, University of Cambridge.

Harte, B., (1975) Determination of a pelite petrogenetic grid for the eastern Scottish Dalradian. Yearbook of the Carnegie Institute, Washington, 74, 438-446.

Harte, B. (1979) The Tarfside succession and the structure and stratigraphy of the eastern Scottish Dalradian rocks. In Special Publications, Geological Society, London, 8 (eds. Harris, A. L., Holland, C. H. and Leake, B. E.), pp. 221-28.

Harte, B. (1987) Glen Esk Dalradian, Barrovian metamorphic zones. In Excursion Guide to the Geology of the Aberdeen area. (editors N.H.Trewin, B.C. Kneller, and C. Gillen,). Scottish Academic press for Geological Society of Aberdeen, Edinburgh, p 193-210.

Harte, B. (1988) Lower Palaeozoic metamorphism in the MoineDalradian belt of the British Isles. In The CaledonianAppalachian Orogen. Harris, A L, and Fettes, D J (editors). Special Publication of the Geological Society of London, No. 38, pp. 123-34.

Harte, B., Booth, J.E., Dempster, T.J., Fettes, D.J., Mendum, J.R. and Watts, D. (1984) Aspects of the post-depositional evolution of Dalradian and Highland Border Complex rocks in the Southern Highlands of Scotland. Transactions of the Royal Society of Edinburgh, 75, 151-63.

Harte, B., Booth, J.E. and Fettes, D.J., (1987) Stonehaven to Findon: Dalradian Structure and Metamorphism. In Excursion Guide to the Geology of the Aberdeen Area (eds Trewin, N. H., Kneller, B. C. and Gillen, C.). Scottish Academic Press for Geological Society of Aberdeen, Edinburgh, pp. 211-26

Harte, B. and Dempster, T.J. (1987) Regional metamorphic zones: tectonic controls. Philosophical Transactions of the Royal Society of London Vol. 321, 105-27.

Harte, B, and Hudson, N.F.C. (1979) Pelite facies series and the temperatures and pressures of Dalradian metamorphism in $E$ Scotland. in The Caledonides of the British Isles-Reviewed. (eds. A.L. Harris, C.H. Holland, and B.E. Leake, ) Geological Society of London Special Publication, 8, pp 323-37.

Harte, B, and Johnson, M.R.w. (1969) Metamorphic history of Dalradian rocks in Glens Clova, Esk and Lethnot, Angus, Scotland. Scottish Journal of Geology, 5, 54-80.

Haselock, P.J. (1982) The geology of the Corrieyairack Pass area, Inverness-shire. Unpublished PhD thesis, University of Keele.

Haselock, P.J. (1984) The systematic geochemical variation between two tectonically separate successions in the southern Monadhliaths, Inverness-shire. Scottish Journal of Geology. 20, $191-205$.

Haselock, P.J. and Gibbons, W. (1990). The Central Highland controversy: a traverse through the Precambrian metasediments of the Central Highlands of Scotland. Episodes 13, 113-15. 
Haselock, P.J. and Leslie, A.G. (1992). Polyphase deformation in Grampian Group rocks of the Monadhliath defined by a group magnetic survey. Scottish Journal of Geology 28, 81-7.

Haselock, P.J., Winchester, J.A. and Whittles, K.H. (1982). The stratigraphy and structure of the southern Monadhliath Mountains between Loch Killin and upper Glen Roy. Scottish Journal of Geology, 18, 275-90.

Heddle, M.F. (1878) Chapters on the mineralogy of Scotland. Chapter fourth - augite, hornblende and serpentinous change. Transactions of the Royal Society of Edinburgh 28, 453-555.

Heddle M. F. (1901) The mineralogy of Scotland. D. Douglas, Edinburgh.

Henderson, S.M.K. (1938) The Dalradian Succession of the Southern Highlands. Report of the meeting of the British Association for the Advancement of Science, Cambridge, 1938, 424.

Henderson, W.G. and Robertson, A.H.F. (1982). The Highland Border rocks and their relation to marginal basin development in the Scottish Caledonides. Journal of the Geological Society of London, $139,433-50$.

Henderson, W.G., Tanner, P.W.G. and Strachan, R.A. (2009) The Highland Border Ophiolite of Scotland: observations from the Highland Workshop field excursion of April 2008. Scottish Journal of Geology, 45, 13-18.

Hibbert, S. (1822) A Description of the Shetland Islands: comprising an account of their geology, scenary, antiquities and superstitions. Constable and Co., Edinburgh.

Hickman, A.H. (1975) The stratigraphy of late Precambrian metasediments between Glen Roy and Lismore. Scottish Journal of Geology, 11, 117-42.

Hickman, A H. (1978) Recumbent folds between Glen Roy and Lismore. Scottish Journal of Geology, 14, 191-212.

Hickman, A.H. and Roberts, J.L. (1977). Discussion of the North Ballachulish Dalradian. Journal of the Geological Society of London, 133, Part 3, 277-79.

Hickman, A.H. and Wright, A.E. (1983) Geochemistry and chemostratigraphical correlation of slates, marbles and quartzites of the Appin Group, Argyll, Scotland. Transactions of the Royal Society of Edinburgh: Earth Sciences, 73, 251-78.

Highton, A.J. (1986). Caledonian and pre-Caledonian events in the Moine south of the Great Glen Fault, Unpublished PhD thesis, University of Liverpool.

Highton, A.J. (1992). The tectonostratigraphical significance of pre-750 Ma metagabbros within the northern Central Highlands, Inverness-shire. Scottish Journal of Geology 28, 71-6.

Highton, A.J. (1999). Solid Geology of the Aviemore District. Memoir of the British Geological Survey, Sheet 74E (Scotland).

Highton, A.J., Hyslop, E.K. and Noble, S.R. (1999).U-Pb zircon geochronology of migmatization in the northern Central Highlands: evidence for pre-Caledonian (Neoproterozoic) tectonmetamorphism in the Grampian Block, Scotland. Journal of the Geological Society, London, 156, 1195-204.

Hill, J.B. (1899) on the progressive metamorphism of some Dalradian sediments in the region of Loch Awe. Quarterly Journal of the Geological Society, London, 40, 470-93.

Hill, J.B. (1905) The geology of mid-Argyll. Memoirs of the Geological Survey, Scotland. Explanation of Sheet 37. 
Hill, J. and Buist, D. (1994) A Geological Field Guide to the Island of Bute, Scotland. (editor Greensmith, J. T.) Geologists' Association Guide, No. 51, 95 pp. Warwick Press.

Hinxman, L.W. (1896). Explanation of Sheet 75. West Aberdeenshire, Banffshire, parts of Elgin and Inverness. Memoir of the Geological Survey, Scotland.

Hinxman, L. W. and Anderson, E. M. (1915). The geology of MidStrathspey and Strathdearn, including the country between Kingussie and Grantown, Scotland. Memoir of the Geological Survey, Scotland, Sheet 74 (Scotland).

Hinxman, L. W., Carruthers, R. G. and Macgregor, M. (1923). The geology of Corrour and the Moor of Rannoch. Memoir of the Geological Survey, Scotland, Sheet 54 (Scotland).

Hinxman, L.W. and Grant Wilson, J.S. (1902) The geology of Lower Strathspey. Memoir of the Geological Survey, Scotland, sheet 85 (Scotland).

Hoffmann, P.F., Condon, D.J., Bowring, S.A. and Crowley, J.L. (2004) U-Pb zircon date from the Neoproterozoic Ghaub Formation, Namibia: Constraints on Marinoan glaciation. Geology, 32, 817-20.

Holdsworth, R.E., Woodcock, N. and Strachan, R. (2000) Geological Framework of Britain and Ireland. In Geological History of Britain and Ireland (edited by Woodcock, N. and Strachan, R.) Blackwell Science, Oxford.

Holland, C.H. and Sanders, I.S. (editors) 2009. The Geology of Ireland (2nd edition). Dunedin Academic Press, Edinburgh. 576 pp.

Howarth, R.J. and Leake, B.E. (2002) The Life of Frank Coles Phillips (1902-1982) and the Structural Geology of the Moine Petrofabric Controversy. Memoir of the Geological Society, London, 23, 95pp.

Hudson, N.F.C. (1976) Mineral facies in pelitic rocks, with particular reference to the Buchan type metamorphism of northeastern Scotland. Unpublished PhD thesis, University of Edinburgh.

Hudson, N.F.C. (1980) Regional metamorphism of some Dalradian pelites in the Buchan area, $\mathrm{NE}$ Scotland. Contributions to Mineralogy and Petrology, 73, 39-51.

Hudson, N.F.C. (1985) Conditions of Dalradian metamorphism in the Buchan area. Journal of the Geological Society of London, 142, $63-76$.

Hutchison, A.R. and Oliver, G.J.H. (1998) Garnet provenance studies, juxtaposition of Laurentian marginal terranes and timing of the Grampian Orogeny in Scotland. Journal of the Geological Society, London, 155, 541-50.

Hutton D.H.W. (1987) Strike slip terranes and a model for the evolution of the British and Irish Caledonides. Geological Magazine 124, 405-425.

Hutton, D.H.W. and Alsop, G.I. (2004) Evidence for a major Neoproterozoic orogenic unconformity within the Dalradian Supergroup of NW Ireland. Journal of the Geological Society, London, 161, 629-40.

Hutton, D.H.W. and Alsop, G.I. (2005) Discussion on evidence for a major Neoproterozoic orogenic unconformity within the Dalradian Supergroup of NW Ireland. Journal of the Geological Society, London, 162, 221-4.

Hutton J. (1788) Theory of the Earth; or an Investigation of the Laws observable in the Composition, Dissolution, and Restoration of the Land upon the Globe. Transactions of the Royal Society of Edinburgh 1, 209-304. 
Hyslop, E. K. (1992). Strain-induced metamorphism and pegmatite development in the Moine rocks of Scotland. Unpublished PhD thesis, University of Hull.

Hyslop, E.K. and Piasecki, M.A.J. (1999). Mineralogy, geochemistry and the development of ductile shear zones in the Grampian Slide Zone of the Scottish Central Highlands. Journal of the Geological Society, London, 156, 577-90.

Hyslop, E.K. and Pickett, E.A. (1999) Stratigraphy and magmatism in the uppermost Dalradian of the SW Scottish Highlands: A field excursion to Tayvallich, Loch Avich and Tarbert (Loch Fyne). BGS Technical Report WA/99/73.

Indares, A. and Dunning, G.R. (1997) Coronitic metagabbro and eclogite from the Grenville Province of western Quebec; interpretation of $\mathrm{U}-\mathrm{Pb}$ geochronology and metamorphism. Canadian Journal of Earth Sciences 34, 891-901.

Jacques J.M. and Reavy R.J. (1994) Caledonian plutonism and major lineaments in the SW Scottish Highlands. Journal of the Geological Society, London, 151, 955-69.

Jamieson, T.F. (1861) on the structure of the south-west Highlands of Scotland. Quarterly Journal of the Geological Society of London, 17, 133-45.

Jehu, T.J. and Campbell, R. (1917) The Highland Border rocks of the Aberfoyle District. Transactions of the Royal Society of Edinburgh, 52, 175-212.

Johnson, M.R.W. (1962) Relations of movement and metamorphism in the Dalradians of Banffshire. Transactions of the Edinburgh Geological Society, 19, 29-64.

Johnson, M.R.W. (1963) Some time relations of movement and metamorphism in the Scottish Highlands. Geologie en Mijnbouw, 42, $121-42$.

Johnson, M.R.W. (1965) Dalradian. In The Geology of Scotland (1st edition). Craig, G. Y. (ed.) Oliver and Boyd, Edinburgh. 117-60.

Johnson, M.R.W. (1983) Dalradian. In Geology of Scotland (2nd edition), Craig, G. Y. (ed.), Scottish Academic Press, Edinburgh, pp. $77-104$.

Johnson, M.R.W. (1991) Dalradian. In Geology of Scotland (3rd edition). Craig, G. Y. (ed.) The Geological Society, London, pp. 125-60.

Johnson, M.R.W. and Harris, A.L. (1967) Dalradian-?Arenig relations in part of the Highland Border, Scotland, and their significance in the chronology of the Caledonian orogeny. Scottish Journal of Geology, 3, 1-16.

Johnson, M.R.W. and Stewart, F.H. (1960) On Dalradian structures in north-east Scotland. Transactions of the Edinburgh Geological Society, 18, 94-103.

Johnson T.E. (1999) Partial melting in Dalradian pelitic migmatites from the Fraserburgh-Inzie Head area of Buchan, northeast Scotland. Unpublished PhD thesis, University of Derby.

Johnson T.E., Hudson N.F.C. and Droop G.T.R. (2001a) Partial melting in the Inzie Head gneisses: the role of water and a petrogenetic grid in KFMASH applicable to anatectic pelitic migmatites. Journal of Metamorphic Geology, 19, 99-118.

Johnson T.E., Hudson N.F.C. and Droop, G.T.R (2001b) Melt segregation structures within the Inzie Head gneisses of the northeastern Dalradian. Scottish Journal of Geology, 37, 59-72. 
Johnson T.E., Hudson N.F.C. and Droop G.T.R. (2003) Evidence for a genetic granite-migmatite link in the Dalradian of NE Scotland. Journal of the Geological Society, London, 160, 447- 57.

Johnstone, G.S. (1966) British regional geology: the Grampian Highlands (3rd edition). HMSO, Edinburgh for Geological Survey and Museum.

Johnstone, G.S. (1975) The Moine Succession. In A Correlation of Precambrian Rocks in the British Isles (eds. Harris, A. L., Shackleton, R. M., Watson, J.V., Downie, C., Harland, W. B. and Moorbath, S.) Geological Society, London, Special Report, 6, $30-$ 42 .

Johnstone, G.S. and Smith, D.I. (1965) Geological observations concerning the Breadalbane Hydroelectric Project, Perthshire. Bulletin of the Geological Survey of Great Britain, 22, 1-52.

Johnstone, G.S. and Wright, J.E. (1957) The Geology of the tunnels of the Loch Sloy hydroelectric scheme. Bulletin of the Geological Survey of Great Britain, 12, 1-17.

Jones, K.A. (1959) The tectonic and metamorphic history of the Ben More-Am Binnein area, Western Perthshire. Unpublished PhD thesis, University of Wales, Swansea.

Kearns, S. (1989) Metamorphism of calc-silicate and related rocks from the Dalradian of N.E. Scotland. Unpublished PhD thesis, Derbyshire College of Higher Education.

Kennedy, M.J. (1975) The Fleur de Lys Supergroup: stratigraphic comparison of Moine and Dalradian equivalents in Newfoundland with the British Caledonides. Journal of the Geological Society, London, 131, 305-10.

Kennedy W.Q. (1946) The Great Glen Fault. Quarterly Journal of the Geological Society of London, 102, 41-76.

Kennedy, W.Q. (1948) On the significance of thermal structure in the Scottish Highlands. Geological Magazine, 85, 229-34.

Kessler, L.G. and Gollop, I.G. (1988) Inner shelf/shorefaceintertidal transition, Upper Precambrian, Port Askaig Tillite, Isle of Islay, Argyll, Scotland. In Tide Influenced Sedimentology, Environments and Facies (eds. de Boer, P. L., van Gelder, A. and Nio, S. D.), Reidal, Dohdrecht, pp. 341-58.

Key, R.M., Clark, G.C., May, F., Phillips, E.R., Chacksfield, B.C. and Peacock, J.D. (1997). Geology of the Glen Roy district. Memoir of the British Geological Survey, sheet 63w (Scotland).

Kilburn, C., Pitcher, W.S. and Shackleton, R.M. (1965) The stratigraphy and origin of the Portaskaig Boulder Bed series (Dalradian). Geological Journal, 4, 343-60.

Kinny, P.D., Friend, C.R.L., Strachan, R.A., Watt, G.R. and Burns, I.M. (1999) U-Pb geochronology of regional migmatites in East Sutherland, Scotland; evidence for crustal melting during the Caledonian orogeny. Journal of the Geological Society, London, 156, 1143-52.

Kinny, P.D., Strachan, R.A., Friend, C.R.L., Kocks, H., Rogers, G. and Paterson, B.A. (2003a) U-Pb geochronology of deformed metagranites in central sutherland, Scotland; evidence for widespread late Silurian metamorphism and ductile deformation of the Moine Supergroup during the Caledonian orogeny. Journal of the Geological Society of London, 160, 259-69.

Kinny, P.D., Strachan, R.A., Kocks, H. and Friend, C.R.L. (2003b) $\mathrm{U}-\mathrm{Pb}$ geochronology of late Neoproterozoic augen granites in the 
Moine Supergroup, NW Scotland: dating of rift-related, felsic magmatism during supercontinent break-up? Journal of the Geological Society of London, 160, 925-34.

Klein, G.D.V. (1970) Tidal origin of a Precambrian quartzite - the Lower Fine-grained Quartzite (Middle Dalradian) of Islay, Scotland. Journal of Sedimentary Petrology, 40, 973-85.

Klein, G.D.V. (1971) Tidal origin of a Precambrian quartzite - the Lower Fine-grained Quartzite (Middle Dalradian) of Islay, Scotland: Reply. Journal of Sedimentary Petrology, 41, 886-9.

Kneller, B.C. (1985) Dalradian basin evolution and metamorphism. Journal of the Geological Society of London, 142, 4 (abstract).

Kneller, B.C. (1987) A geological history of NE Scotland. 1-50. In Excursion guide to the geology of the Aberdeen area. Trewin, H.N., Kneller, B.C. and Gillen, C. (editors). Scottish Academic Press for Geological Society of Aberdeen, Edinburgh.

Kneller, B.C. (1988) The geology of part of Buchan. Unpublished PhD thesis, University of Aberdeen.

Kneller, B.C. and Aftalion M. (1987) The isotopic and structural age of the Aberdeen Granite. Journal of the Geological Society of London 144, 717-21.

Kneller, B.C. and Leslie, A.G. (1984) Amphibolite facies metamorphism in shear zones in the Buchan area of $\mathrm{NE}$ Scotland. Journal of Metamorphic Geology 2, 83-94.

Knill, J.L. (1959) Palaeocurrents and sedimentary facies of the Dalradian metasediments of the Craignish-Kilmelfort district. Proceedings of the Geologists' Association, 70, 273-84.

Knill, J.L. (1960) The tectonc pattern in the Dalradian of the Craignish-Kilmelfort District, Argyllshire. Quarterly Journal of the Geological Society of London, 115, 339-64.

Knill, J.L. (1963) A sedimentary history of the Dalradian Series. In The British Caledonides. (eds Johnson, M.R.W. and Stewart, F.H.). Oliver and Boyd, Edinburgh, pp. 99-121.

Krabbendam, M. and Leslie, A.G. (1996) Folds with vergence opposite to the sense of shear. Journal of Structural Geology, 18, 777-81.

Krabbendam, M., Leslie, A.G., Crane, A. and Goodman, S. (1997) Generation of the Tay Nappe, Scotland, by large-scale SE-directed shearing. Journal of the Geological Society, London, 154, 15-24.

Krabbendam, M., Prave, A.R. and Cheer, D.A. (2008) A fluvial origin for the Neoproterozoic Morar Group, NW Scotland; implications for Torridon-Morar Group correlation and the Grenville Orogen foreland basin. Journal of the Geological Society, London, 165, 379-94.

Kruhl, J. and Voll, G. (1975) Large scale pre-metamorphic and precleavage inversion at Loch Leven, Scottish Highlands. Neues Jahrbuch für Mineralogie, 2, 71-8.

Kynaston, H. and Hill J.B. (1908) The Geology of the country near oban and Dalmally. Memoir of the Geological Survey, sheet 45 (Scotland).

Lambert, R.St. J. (1975) Discussion of Moine-Dalradian relationships in the River Leven. Journal of the Geological Society of London, 131, 327-8.

Lambert, R.St.J., Holland, J.G. and Winchester, J.A. (1982) A geochemical comparison of the Dalradian Leven Schists and the Grampian Division Monadhliath Schists of Scotland. Journal of the Geological Society of London, 139, 71-84. 
Lambert, R.St.J. and McKerrow, W.S. (1976) The Grampian Orogeny. Scottish Journal of Geology, 12, 271-92.

Lambert, R.St.J, Winchester, J.A. and Holland, J.G. (1981) Comparative geochemistry of pelites from the Moinian and Appin Group (Dalradian) of Scotland. Geological Magazine, $118,477-90$.

Lawson, J. D. and Weedon, D. S. (editors) (1992) Geological Excursions around Glasgow and Girvan. Geological Society of Glasgow, Glasgow.

Leake, B.E. (1982) Volcanism in the Dalradian. In Igneous rocks of the British Isles. Sutherland, D. S. (editor). John Wiley and Sons, Chichester, pp. 45-50.

Leake, B.E. and Tanner, P.W.G. (1994) The Geology of the Dalradian and Associated Rocks of Connemara, Western Ireland: a report to accompany the 1:63360 geological map and cross sections. Royal Irish Academy, Dublin.

Lee, G.W. and Bailey, E.B. (1925) The pre-Tertiary geology of Mull, Loch Aline and Oban. Memoir of the Geological Survey of Great Britain, Sheet 44 (Scotland).

Leggo, P.J., Tanner, P.W.G. and Leake, B.E. (1969) Isochron study of Donegal Granite and certain Dalradian rocks of Britain. In North Atlantic-geology and Continental Drift, a symposium (ed. M. Kay), Memoir of the American Association of Petroleum Geologists, 12, pp. 354-62.

Le Maitre, R.W (editor) (2002). Igneous Rocks: a Classification and Glossary of Terms; Recommendations of the International Union of Geological Sciences Subcommission on the Systematics of Igneous Rocks. Cambridge University Press, Cambridge, $236 \mathrm{pp}$.

Leslie, A.G., Chacksfield, B.C., Smith, M. and Smith, R.A. (1999). The Geophysical signature of a major shear zone in the central Highlands of Scotland. British Geological Survey Technical Report No. WA/99/32R.

Leslie, A.G., Krabbendam, M. and Smith, R.A. (2006) The Gaick Fold Complex: large-scale recumbent folds and their implications for Caledonian structural architecture in the central Grampian Highlands. Scottish Journal of Geology, 42, 149-60.

Leslie, A.G., Smith, M. and Soper, N.J. (2008) Laurentian margin evolution and the Caledonian orogeny-a template for Scotland and East Greenland. In The Greenland Caledonides: Evolution of the Northeast Margin of Laurentia. Higgins, A.K., Gilotti, J.A. and Smith, M.P. (editors), Geological Society of America Memoir, 202, $307-43$.

Lindsay, N.G. (1988) Contrasts in Caledonian tectonics of the Northern and Central Highlands. Unpublished PhD thesis, University of Liverpool.

Lindsay, N.G., Haselock, P.J. and Harris, A.L. (1989). The extent of Grampian orogenic activity in the Scottish Highlands. Journal of the Geological Society of London, 146, 733-5.

Litherland, M. (1970) The stratigraphy and structure of the Dalradian rocks around Loch Creran, Argyll. Unpublished PhD thesis, University of Liverpool.

Litherland, M. (1975) Organic remains and traces from the Dalradian of Benderloch, Argyll. Scottish Journal of Geology, 11, 47-50.

Litherland, M. (1980) The stratigraphy of the Dalradian rocks around Loch Creran, Argyll. Scottish Journal of Geology, 16, 10523 . 
Litherland, M. (1982) The structure of the Loch Creran Dalradian and a new model for the SW Highlands. Scottish Journal of Geology, $18,205-25$.

Loudon, T.V. (1963) The sedimentation and structure in the Macduff District of North Banffshire and Aberdeenshire. Unpublished PhD thesis, University of Edinburgh.

Lowe, D. R. 1976. Subaqueous liquified and fluidised sediment flows and their deposits. Sedimentology, 23, pp. 285-308.

Lyubetskaya, T. and Ague, J.J., 2010. Modeling metamorphism in collisional orogens intruded by magmas: fluid flow and implications for Barrovian and Buchan metamorphism, Scotland. American Journal of Science, 310, 459-491.

McAteer, C.A., Daly, J.S., Flowerdew, M.J., Connelly, J.N., Housh, T.B. and Whitehouse, M.J. (2010) Detrital zircon, detrital titanite and igneous clast $\mathrm{U}-\mathrm{Pb}$ geochronology and basement-cover relationships of the Colonsay Group, sw Scotland: Laurentian provenance and correlation with the Neoproterozoic Dalradian Supergroup. Precambrian Research, 181, 21-42.

McCallien, W.J. (1925) Notes on the Geology of the Tarbet district of Loch Fyne. Transactions of the Geological Society of Glasgow, $17,233-63$.

McCallien, W.J. (1926) The structure of South Knapdale (Argyll). Transactions of the Geological Society of Glasgow, 17, 377-94.

Mccallien, W.J. (1929) The metamorphic rocks of Kintyre. Transactions of the Royal Society of Edinburgh, 56, 40936 .

Mccallien, W.J. (1938) The Geology of Bute. Transactions of the Buteshire Natural History Society, 12, 84-112.

McCay, G.A., Prave, A.R., Alsop, G.I. and Fallick, A.E. (2006) Glacial trinity: Neoproterozoic Earth history within the BritishIrish Caledonides. Geology, 34, 909-12.

McClay, K.R. (1987) The Mapping of Geological Structures. Geological Society of London Handbook, Open University Press, Milton Keynes, $161 \mathrm{pp}$.

McClay K.R., Norton M.G., Cony P. and Davis G.H. (1986) Collapse of the Caledonian Orogen and the old Red Sandstone. Nature, London 323, 147-9.

MacCulloch, J. (1814) Remarks on several parts of Scotland which exhibit quartz rock, and on the nature and connexions of this rock in general. Transactions of the Geological Society, 2, 450-87.

MacCulloch, J. (1819) A description of the western islands of Scotland including the Isle of Man: comprising an account of their geological structure; with remarks on their agriculture, scenary and antiquities. 3 volumes. Constable, London.

MacDonald, J.G. and Herriot, A. (1983) Macgregor's excursion guide to the geology of Arran. (3rd edition). Geological society of Glasgow and University of Glasgow, Glasgow.

Macdonald, R. and Fettes, D.J. (2007) The tectonomagmatic evolution of Scotland. Transactions of the Royal Society of Edinburgh: Earth Sciences, 97, 213-95.

Macdonald, R., Fettes, D.J., Stephenson, D. and Graham, C.M. (2005) Basic and ultrabasic volcanic rocks from the Argyll Group (Dalradian) of NE Scotland. Scottish Journal of Geology, 41, 15974 . 
MacGregor, A.G. (1948) British regional geology: the Grampian Highlands (2nd edition), HMSO for Geological Survey and Museum, Edinburgh.

MacGregor, A.R. (1996) Edzell and Glen Esk. 93-108 in Fife and Angus Geology, an excursion guide (3rd edition) by A.R. MacGregor, Pentland Press, Durham.

MacGregor, S.M.A. and Roberts, J.L. (1963) Dalradian pillow lavas, Ardwell Bridge, Banffshire. Geological Magazine, 100, 17-23.

McIntyre, D.B. (1950) Lineation, boudinage and recumbent folding in the Struan Flags (Moine), near Dalnacardoch, Perthshire. Geological Magazine, 87, 205-25.

McIntyre, D.B. (1951) The tectonics of the area between Grantown and Tomintoul (mid-Strathspey). Quarterly Journal of the Geological Society of London, 107, 1-22.

McKenzie, D.P. and Bickle, M.J. (1988). The volume and composition of melt generated by the extension of the lithosphere. Journal of Petrology, 29, 625-79.

McKie, T. (1990) Tidal and storm-influenced sedimentation from a Cambrian transgressive passive margin sequence. Journal of the Geological Society, London, 147, 785-94.

Mackie, W. (1908) Evidence of contemporaneous volcanic action in the Banffshire schists. Transactions of the Edinburgh Geological Society, 9, 93-101.

McLellan, E.L. (1983) Barrovian migmatites and the thermal history of the south-eastern Grampians. Unpublished PhD thesis, University of Cambridge.

McLellan, E.L., 1985. Metamorphic reactions in the kyanite and sillimanite zones of the Barrovian type area, Journal of Petrology, 26, 789-818.

Macnair, P. (1896) The altered clastic rocks of the Southern Highlands: their structure and succession. Geological Magazine, Decade 4, 3, 167-174, 211-217.

Macnair, P. (1906) On the development of the great axial lines of folding in the Highland schists. Proceedings of the Royal Philosophical Society of Glasgow Vol. 37, 129-xxx.

Macnair, P. (1908) The Geology and Scenery of the Grampians and the Valley of Strathmore, James MacLehose and Sons, Glasgow, 2 volumes, $256 \mathrm{pp}$.

Marcantonio, F., Dickin, A.P., McNutt, R.H. and Heaman, L.M. (1988). A 1880-million year old Proterozoic gneiss terrane in Islay with implications for crustal evolution of Britain. Nature, $335,62-64$.

Mather, J.D. (1968) A geochemical, mineralogical and petrological study of rocks of lower greenschist facies from the Dalradian of Scotland. Unpublished PhD thesis, University of Liverpool.

May, F. (1970) Movement, metamorphism and migmatization in the Scalloway region of Shetland. Bulletin of the Geological Survey of Great Britain, 31, 205-26.

May, F. and Highton, A.J. (1997) Geology of the Invermoriston district. Memoir of the British Geological Survey. Sheet $73 \mathrm{~W}$ (Scotland).

Melezhik, V.A., Gorokhov, I.M., Kuznetsov, A.B. and Fallick, A.E. (2001). Chemostratigraphy of Neoproterozoic carbonates: implications for 'blind dating'. Terra Nova, 13, 1-11.

Mendum, J.R. 1987. Dalradian of the Collieston coast section. 161172 in Excursion guide to the geology of the Aberdeen area. Trewin, $\mathrm{N}$ H, Kneller, B C, and Gillen, C (editors). 
(Edinburgh: Scottish Academic Press for Geological Society of Aberdeen.)

Mendum, J.R., Barber, A.J., Butler, R.W.H., Flinn, D., Goodenough, K.M., Krabbendam, M., Park, R.G. and Stewart, A.D. (2009) Lewisian, Torridonian and Moine rocks of Scotland, Geological Conservation Review Series, No. 34, Joint Nature Conservation Committee, Peterborough, $722 \mathrm{pp}$.

Mendum, J.R. and Fettes, D.J. (1985) The Tay nappe and associated folding in the Ben Ledi-Loch Lomond area. Scottish Journal of Geology, 21, 41-56.

Mendum, J.R. and Noble, S.R. (2010) Mid-Devonian sinistral transpression on the Great Glen Fault: the rise of the Rosemarkie Inlier and the Acadian Event in Scotland. In Continental tectonics and mountain building: the legacy of Peach and Horne. (eds R.D. Law, R.W.H. Butler, R.E. Holdsworth, M. Krabbendam and R.A. Strachan), Geological Society, London, Special Publication, No. 335, pp. 161-187.

Mendum, J.R. and Thomas, C.W. (1997) Discussion on the generation of the Tay Nappe, Scotland, by large-scale SE-directed shearing. Journal of the Geological Society, London, 154, 581-3.

Miall, A. D. 1985. Architectural-element analysis: a new method of facies analysis applied to fluvial deposits. Earth Science Reviews, 22, pp. 261-308.

Miall, A. D. 1992. Alluvial Deposits. In: Walker, R. G. \& James, N. P. (eds), Facies models - response to sea level changes. Geoscience Canada, pp. 119-1992.

Millar, I.L. (1999) Neoproterozoic extensional basic magmatism associated with the West Highland granite gneiss in the Moine Supergroup of NW Scotland. Journal of the Geological Society, London 156, 1153-62.

Moffat, D.T. (1987) The serpentinized ultramafites of the Shetland Caledonides. Unpublished PhD thesis, University of Liverpool.

Moig, N.A.W. (1986) A structural study of the Dalradian rocks of the Banff coastal transect, NE Scotland. Unpublished PhD thesis, University of Dundee.

Moles, N.R. (1985a) Geology, geochemistry and petrology of the Foss stratiform baryte-base metal deposit and adjacent Dalradian metasediments, near Aberfeldy. Unpublished PhD thesis, University of Edinburgh.

Moles, N.R. (1985b) Metamorphic conditions and uplift history in central Perthshire: evidence from mineral equilibria in the Foss celsian-barite-sulphide deposit, Aberfeldy. Journal of the Geological Society of London, 142, 39-52.

Möller, C. (1998) Decompressed eclogites in the Sveconorwegian (Grenvilian) Orogen of SW Sweden; petrology and tectonic implications. Journal of Metamorphic Geology, 16, 641-56.

Molyneux, S.G. 1998. An upper Dalradian microfossil reassessed. Journal of the Geological Society, London, 155, 740-743.

Morgan, W.C. (1966) The metamorphic history of the Dalradian rocks between Tomintoul and Loch Builg, Banfshire. Unpublished Ph D thesis, University of Aberdeen.

Morris, G.A. and Hutton, D.H.W. (1993) Evidence for sinistral shear associated with the emplacement of the early Devonian Etive dyke swarm. Scottish Journal of Geology, 29, 69-72.

Mould, D.D.C.P. (1946) The geology of the Foyers 'granite' and the surrounding country. Geological Magazine, 83, 249-65. 
Muir, R.J. (1990) The Precambrian basement and related rocks of the southern Inner Hebrides, Scotland. Unpublished PhD thesis, University of Wales, Aberystwyth.

Muir, R.J., Fitches, W.R. and Maltman, A.J. (1989) An Early Proterozoic link between Greenland and Scandinavia in the Inner Hebrides of Scotland. Terra Abstract, 1, 5.

Muir, R.J., Fitches, W.R. and Maltman, A.J. (1992). Rhinns Complex: a missing link in the Proterozoic basement of the North Atlantic region. Geology, 20, 1043-6.

Muir, R.J., Fitches, W.R. and Maltman, A.J. (1994a). The Rhinns Complex: Proterozoic basement on Islay and Colonsay, Inner Hebrides, Scotland, and on Inishtrahull, NW Ireland. Transactions of the Royal Society of Edinburgh: Earth Sciences, 85, 77-90.

Muir, R.J., Fitches, W.R., Maltman, A.J. and Bentley, M.R. (1994b) Precambrian rocks of the southern Inner Hebrides-Malin Sea region: Colonsay, west Islay, Inishtrahull and Iona. In: Gibbons, W. and Harris, A.L. (eds) A revised correlation of Precambrian rocks in the British Isles. Geological Society, London, Special Report 22, 54-58.

Muir, R.J., Fitches, W.R. and Maltman, A.J. (1995). The Colonsay Group and basement-cover relationship on the Rhinns of Islay, Inner Hebrides. Scottish Journal of Geology, 31, 125-30.

Munro, M. (1986) Geology of the country around Aberdeen. Memoir of the British Geological Survey, Sheet 77 (Scotland).

Munro, M. and Gallagher, J W. (1984) Disruption of the 'Younger Basic' masses in the Huntly-Portsoy area, Grampian Region. Scottish Journal of Geology, 20, 361-82.

Murchison, R.I. (1851) On the Silurian rocks of the south of Scotland. Quarterly Journal of the Geological Society of London, 7, 139-78.

Murchison, R.I. (1859) Siluria: the History of the Oldest Known Rocks Containing Organic Remains, with a Brief sketch of the Distribution of Gold Over the Earth. 3rd edition. John Murray, London.

Murchison, R.I. and Geikie, A. (1861) On the altered rocks of the Western Islands of Scotland and the North-Western and Central Highlands. Quarterly Journal of the Geological Society of London $17,171-$ ??.

Mutti, E. and Normark, W.R. (1987) Comparing examples of modern and ancient turbidite systems: problems and concepts. In Marine Clastic Sedimentology (eds. Legget, J.K and Zuffa, G.G.), Graham and Trotman, pp.1-38.

Mykura, W. (1976) British Regional Geology: Orkney and Shetland. HMSO, Edinburgh for the Institute of Geological Sciences.

Nell, P.A.R. (1984) The geology of lower Glen Lyon. Unpublished PhD thesis, University of Manchester.

Nell, P.A.R. (1986) Discussion on the Caledonian metamorphic core: an Alpine model. Journal of the Geological Society of London, $143,723-8$.

Nesbitt, R.W. and Hartmann, L.A. (1986) Comments on 'A peridotitic komatiite from the Dalradian of Shetland' by D. Flinn and D.T. Moffat. Geological Journal, 21, 201-5.

Nicol, J. (1844) Guide to the geology of Scotland: Containing an Account of the Character, Distribution and More Interesting Appearances of its Rocks and Minerals. Oliver and Boyd, Edinburgh. 
Nicol, J. (1852) On the geology of the southern portion of the peninsula of Cantyre, Argyllshire. Quarterly Journal of the Geological Society of London, 8, 406-25.

Nicol J. (1863) On the geological structure of the Southern Grampians. Quarterly Journal of the Geological Society of London $19,180-209$.

Noble, S.R., Hyslop, E.K. and Highton, A.J. (1996). High-precision $\mathrm{U}-\mathrm{Pb}$ monazite geochronology of the c. 806 Ma Grampian Shear Zone and the implications for evolution of the Central Highlands of Scotland. Journal of the Geological Society, London, 153, 511-14.

Okonkwo, C.T. (1985). The geology and geochemistry of the metasedimentary rocks of the Loch Laggan-Upper Strathspey area, Inverness-shire. Unpublished PhD thesis, University of Keele.

okonkwo, C.T. (1988). The stratigraphy and structure of the metasedimentary rocks of the Loch Laggan-Upper Strathspey area, Inverness-shire. Scottish Journal of Geology, 24, 21-34.

Oldroyd, D.R. and Hamilton, B.M. (2002) Themes in the early history of Scottish geology. In: Trewin N. H. (ed.) The Geology of Scotland. The Geological Society, London, pp. 27-43.

Oliver, G.J.H. (2001) Reconstruction of the Grampian episode in Scotland: its place in the Caledonian Orogeny. Tectonophysics, $332,23-49$.

Oliver, G.J.H. (2002) Chronology and terrane assembly, new and old controversies. In The Geology of Scotland (edited by Trewin, N. H.) The Geological Society, London, 201-11.

Oliver, G.J.H., Chen, F., Buchwald, R. and Hegner, E. (2000) Fast tectonometamorphism and exhumation in the type area of the Barrovian and Buchan zones. Geology, 28, 459-62.

Oliver, G.J.H., Simon, A.W., Wan, Y., 2008. Geochronology and geodynamics of Scottish granitoids from the late Neoproterozoic break-up of Rodinia to Palaeozoic collision. Journal of the Geological Society, London, 165, 661-674.

Pankhurst, R.J. (1970) The geochronology of the basic igneous complexes. Scottish Journal of Geology, 6, 83-107.

Pankhurst, R.J. and Pidgeon, R.T. (1976) Inherted isotope systems and the source region prehistory of the early Caledonian granites in the Dalradian Series of Scotland. Earth and Planetary Science Letters, 31, 58-66.

Pantin, H.M. (1952) Part 1: The petrology and structure of the Ben Vrackie epidiorite. Part 2: Some new observations on Dalradian stratigraphy and tectonics. Unpublished PhD thesis, University of Cambridge.

Pantin H.M. (1961) The stratigraphy and structure of the Blair Atholl-Ben a' Gloe area, Perthshire, Scotland. Transactions of the Royal Society of New Zealand, 88, 597-622.

Park, R.G. (1992) Plate kinematic history of Baltica during the Middle to Late Proterozoic: a model. Geology 20, 725-8.

Park, R.G. (1994) Early Proterozoic tectonic overview of the northern British Isles and neighbouring terrains in Laurentia and Baltica. Precambrian Research, 68, 65-79.

Parson, L M. (1982) The Precambrian and Caledonian geology of the ground near Fort Augustus, Inverness-shire. Unpublished PhD thesis, University of Liverpool. 
Paterson, I.B., Hall, I.H.S. and Stephenson, D. (1990) Geology of the Greenock district. Memoir of the British Geological Survey, Sheet 30W and part of Sheet 29E (Scotland).

Pattrick, R.A. and Treagus, J.E. (1996) Economic geology of the Schiehallion district, central highlands of Scotland. British Geological Survey Technical Report No. WA/96/89.

Peach, B.N. (1904) Summary of Progress of the Geological Survey of the United Kingdom for 1903, 69.

Peach, B.N. and Horne, J. (1930) Chapters on the Geology of Scotland, Oxford University Press, London.

Peach, B.N., Kynaston, B.A. and Muff, H.B. (1909) The geology of the seaboard of mid Argyll including the islands of Luing, Scarba, the Garvellachs, and the Lesser Isles, together with the northern part of Jura and a small portion of Mull. Memoirs of the Geological Survey of Scotland, sheet 36 .

Peach, B.N., Wilson, J.G.S., Hill, J.B., Bailey, E.B. and Grabham, G.W. (1911) The Geology of Knapdale, Jura and North Kintyre. Memoirs of the Geological Survey of Scotland, Sheet 28.

Peach, B.N. and Horne, J. (1930) Chapters on the Geology of Scotland, Oxford University Press, Oxford.

Peacock, J.D., Berridge, N.G., Harris, A.L. and May, F. (1968) The geology of the Elgin district. Memoir of the Geological Survey of Scotland, Sheet 95 (Scotland).

Phillips, E.R. (1996) The mineralogy and petrology of the igneous and metamorphic rocks exposed in the Macduff district (Sheet 96E), Northeast Scotland. British Geological Survey, Mineralogy and Petrology Technical Report, WG/96/26.

Phillips, E.R. and Auton, C.A. (1997) Ductile fault rocks and metamorphic zonation in the Dalradian of the Highland Border SW of Stonehaven, Kincardineshire. Scottish Journal of Geology, 33, 8393.

Phillips, E.R., Clark, G.C. and Smith, D.I. (1993) Mineralogy, petrology, and microfabric analysis of the Eilrig Shear Zone, Fort Augustus, Scotland. Scottish Journal of Geology, 29, 143-58.

Phillips, E.R., Hyslop, E.K., Highton, A.J and Smith, M. (1999). The timing and $\mathrm{P}-\mathrm{T}$ conditions of regional metamorphism in the Central Highlands. Journal of the Geological Society, London, 156, 1183-93.

Phillips, F.C. (1930) Some mineralogical and chemical changes induced by progressive metamorphism in the Green Bed group of the Scottish Dalradian. Journal of the Mineralogical Society, 22, $240-$ 256.

Phillips, F.C. (1954) The Use of Stereographic Projection in Structural Geology, Arnold, London.

Phillips, W.E.A., Stillman, C.J. and Murphy, T. (1976) A Caledonian plate tectonic model. Journal of the Geological Society of London, $132,579-609$.

Piasecki M.A.J. (1975) Tectonic and metamorphic history of the Upper Findhorn, Inverness-shire, Scotland. Scottish Journal of Geology, 11, 87-115.

Piasecki, M.A.J. (1980). New light on the Moine rocks of the Central Highlands of Scotland. Journal of the Geological Society of London, 137, 41-59.

Piasecki, M.A.J. and van Breemen, O. (1979a) A Morarian age for the "younger Moines" of central and western Scotland. Nature, London, 278, 734-6. 
Piasecki, M.A.J. and van Breemen, O. (1979b). The 'Central Highland Granulites': cover-basement tectonics in the Moine. In The Caledonides of the British Isles - reviewed. (editors. Harris, A.L., Holland, C.H. and Leake, B.E.), The Geological Society of London, Special Publications, 8, 139-44.

Piasecki, M.A.J. and van Breemen, O. (1983) Field and isotopic evidence for a c. 750 Ma tectonothermal event in Moine rocks in the Central Highland region of the Scottish Caledonides. Transactions of the Royal Society of Edinburgh: Earth Sciences, 73, 119-34.

Piasecki, M.A.J., van Breemen, O. and Wright, A.E. (1981) Late Precambrian geology of Scotland, England and Wales. In Geology of the North Atlantic Borderlands, Kerr, J.W. and Fergusson, A.J. (eds). Memoir of the Canadian Society of Petroleum Geologists, 7, 57-94.

Piasecki, M.A.J. and Temperley, S. (1988a). The Central Highland Division. In: Winchester, J.A. (ed) Later Proterozoic stratigraphy of the Northern Atlantic regions. Blackie, Glasgow and London, 4653 .

Piasecki, M.A.J. and Temperley, S. (1988b). The northern sector of the central Highlands. 51-68 in An excursion guide to the Moine geology of the Scottish Highlands. Allison, I, May, F, and Strachan, R A (editors). (Edinburgh: Scottish Academic Press for Edinburgh Geological Society and Geological Society of Glasgow.)

Pickering K.T., Bassett M.G., and Siveter D.J. (1988) Late Ordovician-early Silurian destruction of the Iapetus Ocean: Newfoundland, British Isles and Scandinavia: A discusion. Transactions of the Royal Society of Edinburgh: Earth Sciences, 79, 361-82.

Pickett, E.A. (1997) An introduction to the Green Beds of the Southern Highland Group: previous research and an account of preliminary work carried out in 1997. British Geological Survey Technical Report WA/97/92.

Pickett, E.A., Hyslop, E.K. and Petterson, M.G. (2006) The Green Beds of the SW Highlands: deposition and origin of a basic igneous-rich sedimentary sequence in the Dalradian supergroup of Scotland. Scottish Journal of Geology, 42, 43-57.

Pidgeon R.T. and Compston W. (1992) A Shrimp ion microprobe study of inherited and magmatic zircon from Scottish Caledonian granites. Transactions of the Royal Society, Edinburgh: Earth Sciences, 83, 473-83.

Pitcher, W.S. and Berger, A.R. (1972) The Geology of Donegal: a study of granite emplacement and unroofing. Wiley-Interscience, New York, $435 \mathrm{pp}$.

Plant, J.A., Stone, P. and Mendum, J.R. (1999) Regional geochemistry, terrane analysis and metallogeny in the British Caledonides. In Continental Tectonics. MacNiocaill, C and Ryan, P.D. (editors), Geological Society, London, Special Publication No $164,109-26$.

Plant, J.A., Watson, J.V. and Green, P.M. (1984) Moine-Dalradian relationships and their palaeotectonic significance. Proceedings of the Royal Society, 395a, 185-202.

Powell, R. and Evans, J.A. (1983). A new geobarometer for the assemblage biotite-muscovite-chlorite-quartz. Journal of Metamorphic Geology, 1, 331-6.

Power, M.R. and Pirrie, D. (2000) Platinum-group mineralization within ultramafic rocks at Corrycharmaig, Perthshire: implications 
for the origin of the complex. Scottish Journal of Geology, 36, $143-50$.

Prave, A.R. (1999) The Neoproterozoic Dalradian Supergroup of Scotland: an alternative hypothesis. Geological Magazine, 136, 609-17.

Prave, A.R., Fallick, A.E., Thomas, C.W. and Graham, C.M. (2009a) A composite C-isotope profile for the Neoproterozoic Dalradian Supergroup of Scotland and Ireland. Journal of the Geological Society, 166, 845-857.

Prave, A.R., Strachan, R.A. and Fallick, A.E. (2009b) Global C cycle perturbations recorded in marbles: a record of Neoproterozoic Earth history within the Dalradian succession of the Shetland Islands, Scotland. Journal of the Geological Society, $166,129-135$.

Pringle, I.R. (1972) Rb-Sr age determinations on shales associated with the Varanger Ice Age. Geological Magazine, 109, $465-72$.

Pringle, J. (1940) The discovery of Cambrian trilobites in the Highland Border rocks near Callander, Perthshire (Scotland). British Association for the Advancement of Science: Annual Report for 1939-40, 1, 252.

Pumpelly, R., Wolff, J.E. and Dale, T.N. (1894) Geology of the Green Mountains. United States Geological Survey Memoir, 23, 1157.

Rainbird, R.H., Hamilton, M.A. and Young, G.M. (2001) Detrital zircon geochronology and provenance of the Torridonian, NW Scotland. Journal of the Geological Society, London, 158, 15-27.

Ramsay, D.M. (1959) Structure and metamorphism of Glen Lyon. Unpublished PhD thesis, University of Glasgow.

Ramsay, D.M. and Sturt, B.A. (1979) The status of the Banff Nappe. In The Caledonides of the British Isles-reviewed. Harris, A L, Holland, C H and Leake, B E (editors). Special Publication of the Geological Society of London, No. 8. 145-151

Ramsay, J.G. (1958) Moine-Lewisian relations at Glenelg, Invernessshire. Quarterly Journal of the Geological Society of London 113, 487-523.

Rast, N. (1956) Tectonics of Central Perthshire. Unpublished PhD thesis, University of Glasgow.

Rast, N. (1958) Metamorphic history of the Schiehallion complex, Perthshire. Transactions of the Royal Society of Edinburgh, 64, 413-31.

Rast, N. (1963). Structure and metamorphism of the Dalradian rocks of Scotland. In The British Caledonides. (editors. Johnson, M.R.W. and Stewart, F.H.). Oliver and Boyd, Edinburgh, 123-42.

Rast, N. and Litherland, M. (1970) The correlation of the Ballachulish and Perthshire (Islay) successions. Geological Magazine, 107, 259-72.

Read, H.H. (1919) The two magmas of Strathbogie and Lower Banffshire. Geological Magazine 56, 364-71.

Read, H.H. (1923) The geology of the country around Banff, Huntly, and Turriff, Lower Banffshire and north-west Aberdeenshire. Memoir of the Geological Survey, Scotland. Sheets 86 and 96 (Scotland).

Read, H.H. (1927) The igneous and metamorphic history of Cromar, Deeside. Transactions of the Royal Society of Edinburgh, 55, 31753 . 
Read, H.H. (1928) The Highland Schists of middle Deeside and east Glen Muick. Transactions of the Royal Society of Edinburgh, 55, $755-72$.

Read, H.H. (1933). On quartz-kyanite rocks in Unst, Shetland Islands, and their bearing on metamorphic differentiation. Mineralogical Magazine, 23, 317-28.

Read, H.H. (1934) The metamorphic geology of Unst in the Shetland Islands. Quarterly Journal of the Geological Society of London 90, $637-88$.

Read, H.H. (1935) British Regional Geology: the Grampian Highlands (1st edition). HMSO for Geological Survey and Museum, Edinburgh.

Read, H.H. (1936) The stratigraphical order of the Dalradian rocks of the Banffshire coast. Geological Magazine, 73, 468-75.

Read, H.H. (1937) Metamorphic correlation in the polymetamorphic rocks of the Valla Field Block, Unst, Shetland Islands. Transactions of the Royal Society of Edinburgh, 59, 195-221.

Read, H.H. (1952) Metamorphism and migmatisation in the Ythan Valley, Aberdeenshire. Transactions of the Edinburgh Geological Society, 15, 265-79.

Read, H.H. (1955) The Banff nappe: an interpretation of the structure of the Dalradian rocks of north-east Scotland. Proceedings of the Geologists' Association, 66, 1-29.

Read, H.H. (1960) North-east Scotland: the Dalradian. Geologists' Association Guide, 31. Benham and Co., Colchester.

Read, H.H. and Farquhar, O.C. (1956) The Buchan Anticline of the Banff Nappe of Dalradian rocks in north-east Scotland. Quarterly Journal of the Geological Society of London, 112, 131-56.

Richardson, S.W. and Powell, R. (1976) Thermal causes of the Dalradian metamorphism in the Central Highlands of Scotland. Scottish Journal of Geology, 12, 237-68.

Ritchie, J.D. and Hitchen, K. (1993) Discussion on the location and history of the Walls Boundary fault and Moine thrust north and south of Shetland. Journal of the Geological Society, London, 150, 1003-8.

Roberts, J.L. (1959) Fold Structures in the Dalradian Rocks of Knapdale, Argyllshire. Geological Magazine, 94, 221-9.

Roberts, J.L. (1963) The Dalradian of the southwest highlands of Scotland. Unpublished PhD thesis, University of Liverpool.

Roberts, J.L. (1966a) Sedimentary affiliations and stratigraphic correlation of the Dalradian rocks in the South-west Highlands of Scotland. Scottish Journal of Geology, 2, 200-23.

Roberts, J.L. (1966b) The formation of similar folds by inhomogeneous plastic strain, with reference to the fourth phase of deformation affecting the Dalradian rocks in the southwest Highlands of Scotland. Journal of Geology, 74, 831-55.

Roberts, J.L. (1974) The structure of the Dalradian rocks in the SW Highlands of Scotland. Journal of the Geological Society of London, 130, 93-124.

Roberts, J.L. (1976) The structure of the Dalradian rocks in the north Ballachulish district of Scotland. Journal of the Geological Society of London, 132, 139-54.

Roberts, J.L. (1977a) The evolution and transport of the Tay Nappe: Discussion. Scottish Journal of Geology, 13, 79-80.

Roberts, J.L. (1977b) The Dalradian rocks of Rosneath and Southeast Cowal. Scottish Journal of Geology, 13, 101-11.

Roberts, J.L. (1977c) The Dalradian rocks of Knapdale and North Kintyre. Scottish Journal of Geology, 13, 113-124. 
Roberts, J.L. and Sanderson, D.J. (1974) Oblique fold axes in the Dalradian rocks of the Southwest Highlands. Scottish Journal of Geology, 9, 281-96.

Roberts, J.L. and Treagus, J.E. (1964) A reinterpretation of the Ben Lui Fold. Geological Magazine, 101, 512-16.

Roberts, J.L, and Treagus, J.E. (1975) The structure of the Moine and Dalradian rocks in the Dalmally district of Argyllshire, Scotland. Geological Journal, 10, 59-74.

Roberts, J.L, and Treagus, J.E. (1977a) The Dalradian rocks of the South-west Highlands-Introduction. Scottish Journal of Geology, Vol. 13, 87-99.

Roberts, J.L. and Treagus, J.E. (1977b) The Dalradian rocks of the Loch Leven area. Scottish Journal of Geology, 13, 165-184.

Roberts, J.L. and Treagus, J.E. (1977C) Polyphase generation of nappe structures in the Dalradian rocks of the Southwest Highlands of Scotland. Scottish Journal of Geology. 13, 237-254.

Roberts, J.L, and Treagus, J.E. (1979) Stratigraphical and structural correlation between the Dalradian rocks of the SW and Central Highlands of Scotland. 199-204 in The Caledonides of the British Isles-reviewed. Harris, A.L., Holland, C.H., and Leake, B.E.(editors). Special Publication of the Geological society of London. 8 .

Roberts, J.L, and Treagus, J E. (1980) The structural interpretation of the Loch Leven area. Scottish Journal of Geology, 16, 73-5.

Robertson, S. (1991) Older granites in the south-eastern Scottish Highlands. Scottish Journal of Geology, 27, 21-6.

Robertson, S. (1994) Timing of Barrovian metamorphism and 'older Granite' emplacement in relation to Dalradian deformation. Journal of the Geological Society of London, 151, 5-8.

Robertson, S. (1999) BGS Rock Classification Scheme Volume 2: Classification of metamorphic rocks. British Geological Survey Research Report, RR 99-02.

Robertson, S. and Smith, M. (1999) The significance of the Geal charn-ossian steep Belt in basin development in the Central Scottish Highlands. Journal of the Geological Society, London, 156, $1175-82$.

Rock, N.M.S. (1985) A compilation of analytical data for metamorphic limestones from the Scottish Highlands and Islands, with lists of BGS registered samples, and comments on the reproducibility and accuracy of limestone analyses by different analytical techniques. Mineralogical and Petrological Report British Geological Survey, No. 85/5.

Rock, N.M.S. (1986) Chemistry of the Dalradian (Vendian-Cambrian) metalimestones, British Isles. Chemical Geology, 56, 289-311.

Rock, N.M.S., Macdonald, R. and Bower, J. (1986) The comparative geochemistry of some Highland pelites (Anomalous local limestonepelite successions within the Moine outcrop; II). Scottish Journal of Geology, 22, 107-26.

Rogers, G., Dempster, T.J., Bluck, B.J. and Tanner, P.W.G. (1989) A high precision $\mathrm{U}-\mathrm{Pb}$ age for the Ben Vuirich Granite: implications for the evolution of the Scottish Dalradian Supergroup. Journal of the Geological Society, London, 146, 789-98.

Rogers, G., Hyslop, E.K., Strachan, R.A., Paterson, B.A. and Holdsworth, R.A. (1998) The structural setting and U-Pb geochronology of the Knoydartian pegmatites of $W$ Inverness-shire: evidence for Neoproterozoic tectonothermal events in the Moine of 
NW Scotland. Journal of the Geological Society, London, 155, 68596.

Rogers, G., Kinny, P.D., Strachan, R.A., Friend, C.R.L. and Patterson, B.A. (2001) U-Pb geochronology of the Fort Augustus granite gneiss, constraints on the timing of Neoproterozoic and Paleozoic tectonothermal events in the NW Highlands of Scotland. Journal of the Geological Society, London, 158, 7-14.

Rogers, G. and Pankhurst, R.J. (1993) Unravelling dates through the ages: geochronology of the Scottish metamorphic complexes. Journal of the Geological Society, London, 150, 447-64.

Rollin, K.E. (1994) Geophysical correlation of Precambrian rocks in northern Britain. In A Revised Correlation of Precambrian Rocks in the British Isles. Gibbons, W. and Harris, A.L. (eds.) Geological Society, London, Special Report, 22, 65-74.

Rooney, A.D., Chew, D.M. and Selby, D. (2011) Re - Os geochronology of the Neoproterozoic - Cambrian Dalradian Supergroup of Scotland and Ireland: implications for Neoproterozoic stratigraphy, glaciations and Re - Os systematics. Precambrian Research,

Rose, P.T.S. (1989) The emplacement of the Tay Nappe Scotland. Unpublished PhD thesis, University of Liverpool.

Rose, P.T.S. and Harris, A.L. (2000) Evidence for the lower Palaeozoic age of the Tay Nappe; the timing and nature of Grampian events in the Scottish Highland sector of the Laurentian margin. Journal of the Geological Society, London, 157, 789-98.

Rushton, A.W.A., Owen, A.W., Owens, R.M. and Prigmore, J.K. (1999) British Cambrian and Ordovician stratigraphy, Geological Conservation Review Series No. 18, Joint Nature Conservation Committee, Peterborough.

Russell, M.J., Hall, A.J., Willan, R.C.R., Allison, I., Anderton, R., and Bowes, G. (1984) On the origin of the Aberfeldy celsiantbaritetbase metals deposits, scotland. In Prospecting in areas of glaciated terrain, 1984. Institution of Mining and Metallurgy, London, pp. 159-170.

Ryan, P.D. and Soper, N.J. (2001) Modelling anatexis in intracratonic basins: an example from the Neoproterozoic rocks of the Scottish Highlands. Geological Magazine, 138, 577-588.

Ryan, P.D., Soper, N.J., Snyder, D.B., England, R.W. and Hutton, D.H.W. (1995) The Antrim - Galway Line: a resolution of the Highland Border Fault enigma of the Caledonides of Britain and Ireland. Geological Magazine, 132, 171-184.

Saha, D. (1989) The Caledonian Loch Skerrols Thrust, SW Scotland: Microstructure and Strain. Journal of Structural Geology, 11, 553568 .

Schermerhorn, L.J.G. (1974) Late Precambrian mixtites: glacial and/or non-glacial? American Journal of Science, 274, 673-824.

Schermerhorn, L.J.G. (1975) Tectonic framework of Late Precambrian supposed glacials. In Ice Ages: Ancient and Modern (eds. Wright, A.E. and Moseley, F.), proceedings of the Inter-University Geological Congress (University of Birmingham) (1974), Geological Journal special issue No. 6, 242-247.

Scott, R.A. (1987) Lithostratigraphy, structure and mineralization of the Argyll Group Dalradian near Tyndrum, Scotland. Unpublished PhD thesis, University of Manchester.

Scott, R.A., Pattrick, R.A.D., and Polya, D.A. (1991) Origin of sulphur in metamorphosed stratabound mineralization from the 
Argyll Group Dalradian of Scotland. Transactions of the Royal Society of Edinburgh: Earth Sciences, Vol. 82, 91-98.

Scott, R.A., Polya, D.A., and Pattrick, R.A.D. (1988) Proximal Cu + Zn exhalites in the Argyll Group Dalradian, Creag Bhocan, Perthshire. Scottish Journal of Geology, Vol. 24, 97-112.

Seranne, M. (1992) Devonian extensional tectonics versus Carboniferous inversion in the northern Orcadian basin. Journal of the Geological Society, London, 149, 27-37.

Shackleton, R. M. 1958. Downward-facing structures of the Highland Border. Quarterly Journal of the Geological Society, London, 113, $361-392$.

Shackleton, R.M. (1979) The British Caledonides: comments and summary. 299-304 in The Caledonides of the British Islesreviewed. Harris, A L, Holland, C H, and Leake, B E (editors). Special Publication of the Geological Society of London, No. 8.

Shearman, D.J. and Smith, A.J. (1985) Ikaite, the parent mineral of jarrowite-type pseudomorphs. Proceedings of the Geologists' Association, 96, 305-314.

Sibson, R.H. (1977) Fault rocks and fault mechanisms. Journal of the Geological Society, London, Vol 133, 191-213.

Simpson, A. and Wedden, D. (1974) Downward-facing structures in the Dalradian Leny Grits on Bute. Scottish Journal of Geology, 10, 257-267.

Skelton, A.D.L. (1993) Petrological, geochemical and field studies of fluid infiltration during regional metamorphism of the Dalradian of the SW Scottish Highlands. Unpublished PhD thesis, University of Edinburgh.

Skelton, A.D.L., Bickle, M.J. and Graham, C.M. (1997) Fluid-flux and reaction rate from advective-diffusive carbonation of mafic sill margins in the Dalradian, southwest Scottish Highlands. Earth and Planetary Science Letters, 146, 527-539

Skelton, A.D.L., Graham, C.M. and Bickle, M.J. (1995) Lithological and structural constraints on regional 3-D fluid flow patterns during greenschist facies metamorphism of the Dalradian of the SW Highlands. Journal of Petrology, 36, 563-586.

Skevington, D. (1971) Palaeontological evidence bearing on the age of the Dalradian deformation and metamorphism in Ireland and Scotland. Scottish Journal of Geology, Vol. 7, 285-288.

Smallwood, J.R. (2007) Maskelyne's 1774 Schiehallion experiment revisited. Scottish Journal of Geology, Vol. 43, 15-31.

Smith, A.J. and Rast, N. (1958) Sedimentary dykes in the Dalradian of Scotland. Geological Magazine 95, $234-240$.

Smith, C.G., Gallagher, M.J., Coats, J.S. and Parker, M.E. (1984) Detection and general characteristics of stratabound mineralization in the Dalradian of Scotland. Transactions of the Institution of Mining and Metallurgy (Section B: Applied Earth Science), Vol. 93, B125-133.

Smith, C.G., Gallagher, M.J., Grout, A., Coats, J.S., Vickers, B.P., Peachey, D., Pease, S.F., Parker, M.E. and Fortey, N.J. (1988) Stratabound base-metal materialisation in Dalradian rocks near Tyndrum, Scotland. Mineral Reconnaissance Programme Report, British Geological Survey, No. 93.

Smith, C.G., Goodman, S. and Robertson, S. (2002) Geology of the Ballater district. Memoir of the British Geological Survey, sheet 65E (Scotland).

Smith, M., Robertson, S. and Rollin, K.E. (1999) Rift basin architecture and stratigraphical implications for basement-cover 
relationships in the Neoproterozoic Grampian Group of the Scottish Caledonides. Journal of the Geological Society, London, 156, 11631173 .

Smith, R.A. (1980) The Geology of the Dalradian rocks around Blair Atholl, Central Perthshire, Scotland. Unpublished PhD thesis, University of Liverpool.

Smith, R.A. and Harris, A, L. (1976) The Ballachulish rocks of the Blair Atholl District. Scottish Journal of Geology, Vol. 12, 153157.

Smith, T.E. (1968) Tectonics in Upper Strathspey, Inverness-shire. Scottish Journal of Geology, 4, 68-84.

Snyder, D.B. and Flack, C.A. (1990) A Caledonian age for reflectors within the mantle lithosphere north and west of Scotland. Tectonics, 9, 903-922.

Soper N.J. (1994) Was Scotland a Vendian RRR junction? Journal of the Geological Society, London, 151, 579-582.

Soper N.J. (1994) Neoproterozoic sedimentation on the northeast margin of Laurentia and the opening of Iapetus. Geological Magazine, 131, 291-299.

Soper, N.J. and Anderton, R. (1984) Did the Dalradian slides originate as extensional faults? Nature, London, Vol. 307, 357360 .

Soper, N.J. and England, R.W. (1995) Vendian and Riphean rifting in NW Scotland. Journal of the Geological Society, London 152, 11-14.

Soper, N.J. and Evans, J.A., 1997. Discussion on metamorphism and cooling of the NE Dalradian. Journal of the Geological Society, London. 154, 357-360.

Soper N.J. and Hutton D.H.W. (1984) Late Caledonian sinistral displacements in Britain: Implications for a three-plate collision model. Tectonics 3, 781-794.

Soper, N.J., Ryan, P.D. and Dewey, J.F. (1999) Age of the Grampian Orogeny in Scotland and Ireland. Journal of the Geological Society, London 156, 1231-1236.

Soper N.J., Strachan R.A., Holdsworth R.E., Gayer R.A. and O'Greiling, R.O. (1992) Sinistral transpression and the Silurian closure of Iapetus. Journal of the Geological Society, London 149, $871-880$.

Spear, F.S. (1993) Metamorphic phase equilibria and pressuretemperature-time paths. Mineralogical Society of America.

Spencer, A.M. (1971) Late Precambrian glaciation in Scotland. Memoir of the Geological Society of London, No. 6.

Spencer, A.M. (1981) The late Precambrian Port Askaig Tillite in Scotland. In Earth's pre-Pleistocene glacial record (eds. Hambrey, M. J. and Harland, W. B.), pp. 632-636. Cambridge University Press, Cambridge.

Spencer, A.M. (1985) Mechanisms and environments of deposition of Late Precambrian geosynclinal tillites: Scotland and East Greenland. Palaeogeography, Palaeoclimatology and Palaeoecology, $51,143-157$.

Spencer, A.M. and Pitcher, W.S. (1968) Occurrence of the Port Askaig Tillite in north-east Scotland. Proceedings of the Geological Society of London, No. 1650, 195-198.

Spencer, A.M. and Spencer, M. (1972) The Late Precambrian/Lower Cambrian Bonnahaven Dolomite of Islay and its stromatolites. Scottish Journal of Geology, 8, 269-282.

Spray J.G. and Dunning G.R. (1991) A U/Pb age for the Shetland Islands oceanic fragment, Scottish Caledonides: evidence from 
anatectic plagiogranites in "layer 3" shear zones. Geological Magazine 128, 667-671.

Stephenson, D. (1993) Amphiboles from Dalradian metasedimentary rocks of $\mathrm{NE}$ Scotland: environmental inferences and distinction from meta-igneous amphibolites. Mineralogy and Petrology, Vol. $49,45-62$.

Stephenson, D., Bevins, R.E., Millward, D., Highton, A.J., Parsons, I., Stone, P. and Wadsworth, W.J. (1999) Caledonian Igneous rocks of Great Britain. Geological Conservation Review Series No.17. Joint Nature Conservation Committee, Peterborough. 648pp.

Stephenson, D. and Gould, D. (1995) British regional geology: the Grampian Highlands ( $4^{\text {th }}$ edition). HMSO for the British Geological Survey, London.

Stewart, A.D. (1960) On the sedimentary and metamorphic history of the Torridonian, and the later igneous intrusions of Colonsay and Oronsay. Unpublished PhD thesis, University of Liverpool.

Stewart, A.D. (1962) On the Torridonian sediments of Colonsay and their relationship to the main outcrop in north-west Scotland. Liverpool and Manchester Geological Journal 3, 121-156.

Stewart, A.D. (1969) Torridonian rocks of Scotland reviewed. In Kay, M. (ed.) North Atlantic-Geology and Continental Drift, a symposium. Memoir of the American Association of Petroleum Geologists 12, 595-608.

Stewart, A.D. (1975) 'Torridonian' rocks of western Scotland. In: A correlation of Precambrian rocks in the British Isles (eds. Harris, A. L., Shackleton, R. M., Watson, J.V., Downie, C., Harland, W. B. and Moorbath, S.) Geological Society, London, Special Report, 6, 43-51.

Stewart, A.D. and Hackman, B.D. (1973) Precambrian sediments of Islay. Scottish Journal of Geology, 9, 185-201.

Stewart, M., Strachan, R.A. and Holdsworth, R.E. (1999) Structure and early kinematic history of the Great Glen fault zone, Scotland. Tectonics 18, 326-342.

Stewart, M., Strachan, R.A., Martin, M.W. and Holdsworth, R.E. (2001) Constraints on early sinistral displacements along the Great Glen Fault Zone, Scotland; structural setting, U-Pb geochronology and emplacement of the syn-tectonic clunes Tonalite. Journal of the Geological Society, London 158, 821-830.

Stoker, M.S., Howe, J.A. and Stoker, S.J. (1999) Late Vendian?Cambrian glacially influenced deep-water sedimentation, Macduff Slate Formation (Dalradian), $\mathrm{NE}$ Scotland. Journal of the Geological Society, London, 156, 55-61.

Stone, M. (1957) The Aberfoyle Anticline, Callander, Perthshire. Geological Magazine, 94, 265-276.

Stone, P., Plant, J.A., Mendum, J.R. and Green, P.M. (1999) A regional geochemical assessment of some terrane relationships in the British Caledonides. Scottish Journal of Geology, 35, 145-156.

Strachan, R.A. (2000) The Grampian Orogeny: Mid-Ordovician arccontinent collision along the Laurentian margin of Iapetus. In: Woodcock, N.H. and Strachan, R.A. (eds) Geological History of Britain and Ireland. Blackwell Science Ltd, 88-106.

Strachan, R.A., Harris, A.L., Fettes D.J. and Smith, M. (2002) The Northern Highland and Grampian terranes. In: Trewin N. H. (ed.) The Geology of Scotland. (4th edition) The Geological Society, London, pp. 81-148.

Strachan, R.A. and Holdsworth, R.E. (2000) Proterozoic sedimentation, orogenesis and magmatism on the Laurentian Craton 
(2700-750 Ma). In: Geological history of Great Britain and Ireland (edited by Woodcock, N. and Strachan, R. A.) Blackwell Science. oxford, 52-72.

Stringer, P.J. (1957) Polyphase deformation in the Upper Dalradian rocks of the Southern Highlands of Scotland. Unpublished PhD thesis, University of Liverpool.

Stupavsky, M., Symons, D.T.A. and Gravenor, C.P. (1982) Evidence for metamorphic remagnetisation of the upper Precambrian tillite in the Dalradian Supergroup of Scotland. Transactions of the Royal Society of Edinburgh, 73, 59-65.

Sturt, B.A. (1959) Studies in the metamorphic rocks of the Loch Tummel district, Perthshire. Unpublished PhD thesis, University of Wales, Aberystwyth.

Sturt, B.A. (1961) The geological structure of the area south of Loch Tummel. Quarterly Journal of the Geological Society of London, Vol. 117, 131-156.

Sturt, B.A. and Harris, A.L. (1961) The metamorphic history of the Loch Tummel area. Liverpool and Manchester Geological Journal, Vol. 2, 689-711.

Sturt, B.A., Ramsay, D.M., Pringle, I.R. and Teggin, D.E. (1977) Precambrian gneisses in the Dalradian sequence of $\mathrm{NE}$ Scotland. Journal of the Geological Society of London, Vol. 134, $41-44$.

Sutton, J. and Watson, J.V. (1954) Ice-borne boulders in the Macduff Group of the Dalradian of Banffshire. Geological Magazine, Vol. 91, 391-398.

Sutton, J. and Watson, J.V. (1955) The deposition of the Upper Dalradian rocks of the Banffshire coast. Proceedings of the Geologists' Association, Vol. 66, 101-133.

Sutton, J. and Watson, J.V. (1956) The Boyndie syncline of the Dalradian of the Banffshire coast. Quarterly Journal of the Geological Society of London, Vol. 112, 103-130.

Tanner, P. W. G. 1992. Rosneath Peninsula and Loch Long. In Geological excursions around Glasgow and Girvan (eds. Lawson, J. D. and Weedon, D. S.), pp. 159-185. Geological Society of Glasgow.

Tanner, P. W. G. 1995. New evidence that the Lower Cambrian Leny Limestone at Callander, Perthshire, belongs to the Dalradian Supergroup, and a reassessment of the 'exotic' status of the Highland Border Complex. Geological Magazine, 132, 473-483.

Tanner, P. W. G. 1996. Significance of the early fabric in the contact metamorphic aureole of the 590 Ma Ben Vuirich Granite, Perthshire, Scotland. Geological Magazine, 133, 683-695.

Tanner, P. W. G. 1997. The Highland Border controversy: Reply to a Discussion of 'New evidence that the Lower Cambrian Leny Limestone at Callander, Perthshire, belongs to the Dalradian Supergroup, and a reassessment of the 'exotic' status of the Highland Border Complex'. Geological Magazine, 134, 565-570.

Tanner, P. W. G. 1998a. Interstratal dewatering origin for polygonal patterns of sand-filled cracks: a case study from Late Proterozoic metasediments of Islay, Scotland. Sedimentology, 45, $71-89$.

Tanner, P W G. 1998b. Age of the Grampian event: Reply to a Discussion of 'New evidence that the Lower Cambrian Leny Limestone at Callander, Perthshire belongs to the Dalradian Supergroup, and a reassessment of the 'exotic' status of the Highland Border Complex'. Geological Magazine, Vol. 135, 575-579. 
Tanner, P. W. G. 2005. Discussion on evidence for a major Neoproterozoic orogenic unconformity within the Dalradian Supergroup of $\mathrm{NW}$ Ireland. Journal of the Geological Society, London, 162, 221-224.

Tanner, P.W.G. 2007. The role of the Highland Border Ophiolite in the 470 Ma Grampian Event, Scotland. Geological Magazine Vol. $144,597-602$.

Tanner, P.W.G. 2008. Tectonic significance of the Highland Boundary Fault. Journal of the Geological Society, London Vol. 165, 915921.

Tanner, P.W.G. and Bluck, B.J. (2011) Discussion of 'The Highland Boundary Fault and the Highland Boundary Complex' by B.J. Bluck Scottish Journal of Geology 46, 113-124. Scottish Journal of Geolgy, 47, 89-93.

Tanner, P. W. G. and BLUCK, B. J. 1999. Current controversies in the Caledonides. Journal of the Geological Society, London, 156, 1137-1141.

Tanner, P. W. G. and Evans, J. A. 2003. Late Precambrian U-Pb titanite age for peak regional metamorphism and deformation (Knoydartian orogeny) in the western Moine, Scotland. Journal of the Geological Society, London 160, 555-564.

Tanner, P. W. G. and Leslie, A. G. 1994. A pre-D2 age for the 590 Ma Ben Vuirich Granite in the Dalradian of Scotland. Journal of the Geological Society, London, 151, 209-212.

Tanner P. W. G., Leslie A. G. and Gillespie M.R. 2006. Structural setting and petrogenesis of a rift-related intrusion: the Ben Vuirich Granite of the Grampian Highlands, Scotland. Scottish Journal of Geology, Vol. 42, 113-136.

Tanner, P. W. G. and Pringle, M. 1999. Testing for a terrane boundary within Neoproterozoic (Dalradian) to Cambrian siliceous turbidites at Callander, Perthshire, Scotland. Journal of the Geological Society, London, 156, 1205-1216.

Tanner, P.W.G. and Sutherland, S. 2007. The Highland Border Complex, Scotland: a paradox resolved. Journal of the Geological Society, London, 164, 111-116.

Tannner, P.W.G. and Thomas, P.R. (2010) Major nappe-like D2 folds in the Dalradian rocks of the Beinn Udlaidh area, Central Highlands, Scotland. Earth and Environmental Science Transactions of the Royal Society of Edinburgh. 100, 371-389.

Temperley, S. (1990). The Late Proterozoic to Early Palaeozoic geology of the Glen Banchor area in the Monadhliath Mountains of Scotland, with particular reference to deformation in Knoydartian shear zones and the Caledonian Central Highland steep belt. Unpublished PhD thesis, University of Hull.

Thomas, C W. 1989. Application of geochemistry to the stratigraphic correlation of Appin and Argyll Group carbonate rocks from the Dalradian of northeast Scotland. Journal of the Geological Society of London, Vol. 146, 631-647.

Thomas, C. W. 1993. Sources of Rare Earth elements in Appin Group limestones, Dalradian, north-east Scotland. Mineralogy and Petrology Vol. 49, 27-44.

Thomas, C.W. (1995). The geochemistry of metacarbonate rocks from the Monadhliath Project area. British Geological Survey Technical Report. WA/95/40/R.

Thomas, C. W. (1999). The isotope Geochemistry and Petrology of Dalradian Metacarbonate Rocks, Unpublished PhD thesis, University of Edinburgh. 
Thomas, C.W. and Aitchison (1998). Application of logratios to the statistical analysis of the geochemistry of metamorphosed limestones from the Northeast and Central Highlands of Scotland: the case for Appin Group correlations. British Geological Survey Technical Report, WA/98/03.

Thomas, C W, Aitken, A M, Pickett, E P, Mendum, J R, Hyslop, E K, and Petterson, M.P. in press. Geology of the Aberfoyle District. Sheet Description for the British Geological Survey, 1:50 000 Series Sheet 38E (Scotland).

Thomas, C. W., Graham, C. M., Ellam, R.M. and Fallick, A. E. (2004). ${ }^{87} \mathrm{Sr} /{ }^{8} 6 \mathrm{Sr}$ chemostratigraphy of Neoproterozoic Dalradian limestones of Scotland: constraints on depositional ages and timescales. Journal of the Geological Society, London 161, 223243.

Thomas, C.W., Smith, M. and Robertson, S. (1997). The geochemistry of Dalradian metacarbonate rocks from the Schiehallion District and Blargie, Laggan: implications for stratigraphical correlations in the Geal Charn-Ossian Steep Belt. British Geological Survey Technical Report, WA/97/81.

Thomas, P R. 1965. The structure and metamorphism of the Moinian rocks in Glen Garry, Glen Tilt, and adjacent areas of Scotland. Unpublished PhD thesis, University of Liverpool.

Thomas, P R. 1979. New evidence for a Central Highland Root Zone. 205-211 in The Caledonides of the British Isles -Reviewed. Harris, A L, Holland, $\mathrm{CH}$, and Leake, B E (editors). Special Publication of the Geological Society, No. 8.

Thomas, P R. 1980. The stratigraphy and structure of the Moine rocks north of the Schiehallion Complex, Scotland. Journal of the Geological Society of London, Vol. 137, 469-482.

Thomas, P R. 1988. A9 road section-Blair Atholl to Newtonmore. 39-50 in An excursion guide to the Moine geology of the Scottish Highlands. Allison, I, May, F, and Strachan, R A (editors). (Edinburgh: Scottish Academic Press for Edinburgh Geological Society and Geological Society of Glasgow.)

Thomas, P R, and Treagus, J E. 1968. The stratigraphy and structure of the Glen Orchy area, Argyllshire, Scotland. Scottish Journal of Geology, Vol. 4, 121-134.

Thomson, J. 1877. On the geology of the Island of Islay. Transactions of the Geological Society of Glasgow, 5, 200-222.

Tilley, C.E. (1925) A preliminary survey of metamorphic zones in the southern Highlands of Scotland. Quarterly Journal of the Geological Society of London, Vol. 81, 100-110.

Tollo R. P., Aleinikoff J. N., Bartholomew M. J. and Rankin D. W. 2004. Neoproterozoic A-type granitoids of the central and southern Appalachians: intraplate magmatism associated with episodic rifting of the Rodinian supercontinent. Precambrian Research, 128, 3-38.

Torsvik, T. H., Smethurst, M. A., Meert, J. G., Van der Voo, R., McKerrow, W. S., Brasier, M. D., Sturt, B. A. and Walderhaug, H. J. 1996. Continental break-up and collision in the Neoproterozoic and Palaeozoic-a tale of Baltica and Laurentia. Earth Science Reviews 40, 229-258.

Treagus, J. E. 1964a. The structural and metamorphic history of an area of Moine and Dalradian rocks south of Loch Rannoch, Perthshire. Unpublished PhD thesis, University of Liverpool.

Treagus, J E. 1964b. Notes on the structure of the Ben Lawers Synform. Geological Magazine, Vol. 101, 260-270. 
Treagus, J.E. (1969). The Kinlochlaggan Boulder Bed. Proceedings of the Geological Society of London, 1654, 55-60.

Treagus, J E. 1974. A structural cross-section of the Moine and Dalradian rocks of the Kinlochleven area, Scotland. Journal of the Geological Society of London, Vol. 130, 525-544.

Treagus, J.E. (1981). The Lower Dalradian Kinlochlaggan Boulder Bed, Central Scotland. In: Earth's pre-Pleistocene glacial record. (editors. Hambrey, J.M. and Harland, W.B.), Cambridge University Press, 637-639.

Treagus, J E. 1987. The structural evolution of the Dalradian of the Central Highlands of Scotland. Transactions of the Royal Society of Edinburgh: Earth Sciences, Vol. 78, 1-15.

Treagus, J E. 1991. Fault displacements in the Dalradian of the Central Highlands. Scottish Journal of Geology, Vol. 27, 135-145.

Treagus, J. E. (editor). 1992. Caledonian Structures in Britain South of the Midland Valley, Geological Conservation Review Series No. 3. London: Chapman and Hall.

Treagus, J.E. (1997) Discussion on a late Vendian age for the Kinlochlaggan Boulder bed (Dalradian). Journal of the Geological Society, London, 154, 917-919.

Treagus, J E. 1999. A structural reinterpretation of the Tummel Belt and a transpressional model of evolution of the Tay Nappe in the Central Highlands of Scotland. Geological Magazine, Vol. 136, Pt 6, 643-660.

Treagus, J. E. 2000. The Solid Geology of the Schiehallion District. Memoir of the British Geological Survey. Sheet 55W (Scotland).

Treagus, J.E. 2009. The Dalradian of Scotland. Geologists' Association Guide No. 67. 202pp.

Treagus, J E, and King, G. 1978. A complete Lower Dalradian succession in the Schiehallion district, central Perthshire. Scottish Journal of Geology, Vol. 14, 157-166.

Treagus, J E, Pattrick, R A D, and Curtis, S F. 1999. Movement and mineralization in the Tyndrum fault zone, Scotland and its regional significance. Journal of the Geological Society, London, Vol. 156, 591-604.

Treagus, J E. and Roberts, J L. 1981. The Boyndie Syncline, a D1 structure in the Dalradian of Scotland. Geological Journal, Vol. $16,125-135$.

Treagus, J E, Talbot, C J, and Stringer, P. 1972. Downward-facing structures in the Birnam Slates, Dunkeld, Perthshire. Geological Journal, Vol. 8, 125-128.

Treagus, J E, and Treagus, S H. 1971. The structures of the Ardsheal peninsula, their age and regional significance. Geological Journal, Vol. 7, 335-346.

Treagus, J E, and Treagus, S H. 1981. Folds and the strain ellipsoid; a general model. Journal of Structural Geology, Vol. 3, Pt 1, 1-17.

Trewin, N. H. (editor) 2002. The Geology of Scotland. (4 $4^{\text {th }}$ edition) The Geological Society, London. $576 \mathrm{pp}$.

Trewin, N.H., Kneller, B.C. and Gillen, C. (1987) Excursion Guide to the Geology of the Aberdeen area. (Edinburgh: Scottish Academic Press, for Geological Society of Aberdeen).

Trewin, N.H. and Rollin, K. 2002. In: Trewin, N.H. (ed.) The geology of Scotland.(4 ${ }^{\text {th }}$ edition) The Geological Society, London, $1-25$. 
Trewin, N.H. and Thirlwall, M.F. 2002. Old Red Sandstone. In: Trewin N. H. (ed.) The Geology of Scotland. (4th edition) The Geological Society, London, pp. 213-249.

Tyrrell, G.W. 1921. Some points in petrographic nomenclature. Geological Magazine Vol. 58, 494-502.

Underhill, J.R. 1993. Discussion on the location and history of the Walls Boundary fault and Moine thrust north and south of Shetland. Journal of the Geological Society, London, 150, 1003-1008.

Upton, P.S., 1983. A stratigraphic, structural and metamorphic study of the lower and middle Dalradian, between Braemar and the Spittal of Glenshee, N.E. Scotland. Unpublished PhD thesis, University of Manchester.

Upton, P S. 1986. A structural cross-section of the Moine and Dalradian rocks of the Braemar area. Report of the British Geological Survey, Vol. 17, No. 1, 9-19.

Van Breemen, O., Aftalion, M. and Johnson, M. R. 1979. Age of the Loch Borrolan complex, Assynt and late movements along the Moine Thrust Zone. Journal of the Geological Society of London 16, 489495.

Van de Kamp, P.C. 1968. Origins of para-amphibolites. Unpublished PhD thesis, University of Bristol.

Van de Kamp, P C. 1970. The Green Beds of the Scottish Dalradian Series: geochemistry, origin and metamorphism of mafic sediments. Journal of Geology, Vol. 78, 281-303.

Van Staal, C. R., Dewey, J. F., McKerrow, W. S. and MacNiocaill, C. 1998. The Cambrian-Silurian tectonic evolution of the northern Appalachians and British Caledonides: history of a complex, southwest Pacific-type segment of Iapetus. In: Lyell: the Present is in the Past (edited by Blundell, D. J. and Scott, A. C.). Geological Society, London, Special Publication, 143, 199-242.

Vance, D., Strachan, R. A. and Jones, K. A. 1998. Extensional versus compressional settings for metamorphism: Garnet chronometry and pressure-temperature-time histories in the Moine Supergroup, northwest Scotland. Geology 26, 927-930.

Viete, D.R., Forster, M.A. and Lister, G.S. (2011) The nature and origin of the Barrovian metamorphism, Scotland: ${ }^{40} \mathrm{Ar} /{ }^{39} \mathrm{Ar}$ apparent age patterns and the duration of metamorphism in the biotite zone. Journal of the Geological Society, London, 168, 133-146.

Viete, D.R., Hermann, J., Lister, G.S. and Stenhouse, I.R. (2011) The nature and origin of the Barrovian metamorphism, Scotland: diffusion length scales in garnet and inferred thermal time scales. Journal of the Geological Society, London, 168, 115-132.

Viete, D.R., Richards, S.W., Lister, G.S., Oliver, G.J.H. and Banks, G.J. (2010) Lithospheric-scale extension during Grampian orogenesis in Scotland. in Law, R.D., Butler, R.W.H., Holdsworth, R.E., Krabbendam, M. and Strachan, R.A. (editors) Continental Tectonics and Mountain Building: the Legacy of Peach and Horne. Geological Society, London, Special Publications, 335, 121-160.

Viljoen, M. J and Viljoen, R. P. 1969. Evidence for the existence of a mobile extrusive peridotite magma from the Komati Formation of the Onverwacht Group. Geological Society of South Africa, Special Publication No. 2, 87-112.

Vogt, T. 1930. On the chronological order of deposition in the Highlands. Geological Magazine, 67, 68-76. 
Voll, G. 1960. New work on Petrofabrics. Liverpool and Manchester Geological Journal, 2, 503-567.

Voll, G. 1964. Deckenbau und fazies im Schottischen Dalradian. Geologische Rundschau, Vol. 53, 590-612.

Vorhies, S.H. and Ague, J.J. (2011) Pressure - temperature evolution and thermal regimes in the Barrovian zones, Scotland. Journal of the Geological Society, London, 168, 1147-1166.

Wain, A. (1999). The petrography and metamorphic evolution of metabasic rocks from the Lower Dalradian of the Central Highlands area. British Geological Survey Technical Report No. WA/99/13.

Watkins, K.P. 1982. The structure and metamorphism of the Balquhidder-Crianlarich region of the Scottish Dalradian. Unpublished PhD thesis, University of Cambridge.

Watkins, K P. 1983. Petrogenesis of Dalradian albite porphyroblast schists. Journal of the Geological Society of London, Vol. 140, 601-618.

Watkins, K P. 1984. The structure of the Balquhidder-Crianlarich region of the Scottish Dalradian and its relation to the Barrovian garnet isograd surface. Scottish Journal of Geology, Vol. 20, 5364 .

Watkins, K.P. 1985. Geothermometry and geobarometry of inverted metamorphic zones in the $W$. Central Scottish Dalradian. Journal of the Geological Society of London, 142, 157-165.

Watson, J. V. 1984. The ending of the Caledonian Orogeny in Scotland. Journal of the Geological Society of London 141, 193214 .

Weiss, L E, and McIntyre, D B. 1957. Structural geometry of Dalradian rocks at Loch Leven, Scottish Highlands. Journal of Geology, Vol. 65, 575-602.

Wells, P. R. A. and Richardson, S. W. 1979. Thermal evolution of metamorphic rocks in the Central Highlands of Scotland. In Harris, A. L., Holland, C. H. and Leake, B. E. (editors), The Caledonides of the British Isles-reviewed. Geological Society of London Special Publication No. 8, published by Scottish Academic Press, Edinburgh, 339-344.

Whalen J. B., Currie J. L. and Chappell B. W. 1987. A-type granites: geochemical characteristics, discrimination and petrogenesis. Contributions to Mineralogy and Petrology, 95, 407419.

Whitten, E H T. 1959. A study of two directions of folding; the structural geology of the Monadhliath and mid-Strathspey. Journal of Geology, Vol. 67, 14-47.

Whittles, K.H. 1981. The geology and geochemistry of the area west of Loch Killin, Inverness-shire. Unpublished PhD thesis, University of Keele.

Wilkinson, S. B. 1907. The geology of Islay. Memoirs of the Geological Survey of Scotland, Sheets 19 and 27, and parts of 20.

Willan, R. C. R., and Coleman, M L. 1983. Sulphur isotope study of the Aberfeldy barite, zinc, lead deposit and minor sulfide mineralization in the Dalradian metamorphic terrain, Scotland. Economic Geology, Vol. 78, 1619-1656.

Williamson, D. H., 1953. Petrology of chloritoid and staurolite rocks north of Stonehaven, Kincardineshire. Geological Magazine, $90,353-361$. 
Williamson, $W$ O. 1935. The composite gneiss and contaminated granodiorite of Glen Shee, Perthshire. Quarterly Journal of the Geological Society of London, Vol. 91, 382-422.

Wilson, J.R. and Leake, B.E. 1972. The petrochemistry of the epidiorites of the Tayvallich Peninsula, North Knapdale, Argyllshire. Scottish Journal of Geology 8, 215-252.

Winchester, J.A. 1974. The zonal pattern of regional metamorphism in the Scottish Caledonides. Journal of the Geological Society of London, 130, 509-24.

Winchester, J.A. and Glover, B.W. (1988). The Grampian Group, Scotland. In: Later Proterozoic stratigraphy of the Northern Atlantic region. (editor Winchester, J.A.). Blackie, Glasgow and London, 146-161.

Winchester, J.A. and Glover, B.W. (1991). Grampian Group: PitlochryLoch Laggan-Glen Spean. In: The Late Precambrian Geology of the Scottish Highlands and Islands. (editors Hambrey, M.J., Fairchild, I.J., Glover, B.W., Stewart, A.D., Treagus, J.E. and Winchester, J.A.). Geologists' Association Guide No. 44, 66-85.

Wiseman, J D H. 1934. The central and south-west Highland epidiorites: a study in progressive metamorphism. Quarterly Journal of the Geological Society of London, Vol. 90, 354-417.

Wood, D.S. 1964. Some structures in the Dalradian pillow lavas of the Tayvallich Peninsula, Argyll. Geological Magazine, 101, 481

Woodcock, N. and Strachan, R. 2000. Geological History of Britain and Ireland. Blackwell Science, Oxford.

Wright, A.E. 1976. Alternating subduction direction and the evolution of the Atlantic Caledonides Nature, London 264, 156.

Wright, A. E. 1988. 15. The Appin Group. In Later Proterozoic Stratigraphy of the Northern Atlantic Regions (editor Winchester, J. A.), pp. 177-199. Blackie.

Yardley B. W. D. (1989) An introduction to metamorphic petrology. Longman, Harlow.

Yardley, B.W.D. and Valley, J.W. 1997. The petrologic case for a dry lower crust. Journal of Geophysical Research, 106 B6, 1217312185 .

Zeh, A. and Millar, I. L. 2001. Metamorphic evolution of garnetepidote-biotite gneiss from the Moine Supergroup, Scotland, and geotectonic implications. Journal of Petrology 42, 529-554.

Zenk, M. and Schulz, B. 2004. Zoned Ca-amphiboles and related P-T evolution in metabasites from the classical Barrovian metamorphic zones in Scotland. Mineralogical Magazine, 68, 769-786.

Figure 1 Map of the North-east Grampian Highlands based upon BGS 1:50 000-scale maps and showing the location of Dalradian GCR sites.

GCR sites: 1 Ben Vuirich, 2 Gilbert's Bridge, Glen Tilt, 3 Glen Ey gorge, 4 Cairn Leuchan, 5 Balnacraig, Dinnet, 6 Muckle Fergie Burn, 7 Bridge of Brown, 8 Bridge of Avon, 9 Kymah Burn, 10 Black Water, 11 Auchindoun Castle, 12 Cullen to Troup Head, 13 Fraserburgh to Rosehearty, 14 Cairnbulg to St Combs, 15 Collieston to Whinnyfold.

BS Boundary Slide, KSZ Keith Shear-zone, PSZ Portsoy Shear-zone. 
Figure 2 Principal stratigraphical units in the Dalradian of the North-east Grampian Highlands, adapted from Stephenson and Gould (1995, figure 10). The columns are not to scale.

\section{Figure 3}

(a) Generalized cross-section along the north coast of the Northeast Grampian Highlands from Cullen to Fraserburgh showing the main structural features and dominant deformation/fold phases (Stephenson and Gould, 1995, figure 21, partly after Loudon, 1963). Stipple = the Old Red Sandstone outlier at Gardenstown. The entire section is included in the cullen to Troup Head and Fraserburgh to Rosehearty GCR sites.

(b) Highly generalized cross-section across the Buchan Block to illustrate the broad structure as envisaged by Read (1955) as modified by Kneller (1987). The approximate locations of GCR sites relative to the structure are shown.

Figure 4 Map of the Ben Vuirich Granite Intrusion and adjoining country rocks, showing the locations of the two groups of exposures ( $A$ and $B$ ) which comprise the GCR site. $g$ exposure of pelitic schist with garnet over $2 \mathrm{~cm}$ across.

Figure 5 Hornfels associated with the Ben Vuirich Granite, with centimetre-scale, altered porphryoblasts of contact metamorphic cordierite (pale grey), dotted with small garnets (white) that formed during the subsequent D2 regional metamorphism. (Locality A, Figure 4). (Photo: P.W.G. Tanner.)

Figure 6 Xenoliths of banded quartzose psammite and pelite in the Ben Vuirich Granite at locality B, Figure 4. See text for explanation. The scale is $5 \mathrm{~cm}$ long. (Photo: P.W.G. Tanner.)

Figure 7 Map of the area around the Gilbert's Bridge GCR site, based upon the BGS 1:50 000 Sheet 55E (Pitlochry, 1981).

Figure 8 Map of the area around lower Glen Ey adapted from the BGS 1:50 000 Sheet 65W (Braemar, 1989). In this area most of the information used for the BGS compilation was taken from Upton (1983).

Figure 9 Schematic structural cross-section across the area between Deeside and Glen Shee. Reproduced from Upton (1986, figure 3). The rectangle indicates the approximate position and exposure level of the Glen Ey Gorge GCR site.

Figure 10 Map of the area around the Cairn Leuchan to Pannanich Hill GCR site, adapted from the BGS 1:50 000 Sheet 65E (Ballater, 1995). The Coyles of Muick Intrusion is bounded on both sides by ductile shears that define the Coyles of Muick Shear-zone. The shear-zone also marks the position of the regional andalusitekyanite isograd; to the north-west metasedimentary rocks contain andalusite \pm staurolite (a Buchan-type assemblage), whereas to the south-east they contain the assemblage sillimanite \pm kyanite \pm staurolite, characteristic of Barrovian metamorphism. 
Figure 11 Map of the area around Balnacraig, Dinnet. Modified after Gould (2001, figure 11)

Figure 12 Xenolithic gneiss with folded remnants of psammite dispersed in poorly foliated feldspar-porphyroblast gneiss. Craigie, $1.5 \mathrm{~km}$ north-east of Dinnet (NJ 476 007). Coin is $26 \mathrm{~mm}$ in diameter. (Photo: BGS No. P220491, reproduced with the permission of the Director, British Geological Survey, (c) NERC.)

Figure 13 Amphibolite, with irregular patches of feldspathic material, Balnacraig Cottage, north-east of Dinnet (NJ 4787 0056). Coin is $25 \mathrm{~mm}$ in diameter. (Photo: BGS No. P 220371, reproduced with the permission of the Director, British Geological Survey, (c) NERC. )

Figure 14 Map of the Muckle Fergie Burn section, Glen Avon, based upon British Geological Survey mapping, 1982-88.

Figure 15 Granitic cobbles, typically up to $10 \mathrm{~cm}$ across, in metadiamictite in the lower part of the Muckle Fergie Burn (NJ 1657 1397). The smaller clasts include granite, quartz and ochreous yellow-brown-weathering metadolostone (see example at bottom right). (Photo: J R Mendum, BGS No. P 726597)

Figure 16 Map of the area around Bridge of Brown, based upon BGS 1:10 000 Sheet NJ12SW (1991). The line of part of the crosssection in Figure 17 is indicated.

Figure 17 North-west-south-east cross-section across the area surrounding the Bridge of Brown and Bridge of Avon GCR sites. The line of section intersects Figure 16 and passes to the south-west of Figure 18 .

Figure 18 Map of the area around the Bridge of Avon, based upon BGS 1:10 000 sheets NJ12SW (1991) and NJ12SE (1992) and on BGS 1:50 000 Sheet 75W (Glenlivet, 1996). The cross-section of Figure 17 passes the south-west corner of this map.

Figure 19 Asymmetrical minor $\mathrm{F} 3$ folds of thinly interbedded metalimestone, calcsilicate rock and calcareous semipelite of the Ailnack Phyllite and Limestone Formation at Bridge of Avon (NJ 150 201). The folds show attenuated limbs and fold axes plunge at $25^{\circ}$ to 152 . (Photo: BGS No. P 220186, reproduced with the permission of the Director, British Geological Survey, (C) NERC.)

\section{Figure 20}

(a) Map of the Kymah Burn section, Glen Livet, based upon British Geological Survey mapping, 1982-88.

(b) Cross-section along the line A-B showing the major fold interference structure in the Kymah Burn section.

Figure 21 Map of the section through metavolcanic rocks in the lower part of the Blackwater Formation, exposed in the Black Water. Adapted from the BGS 1:10 000 sheet NJ33SE (1993). 
Figure 22 A typical fragmental ultrabasic volcanic rock from the Kelman Hill Member of the Blackwater Formation. The dominant, pale, subrounded to subangular clasts are derived from picritic lavas and there are smaller, darker and more-rounded clasts that are probably from metabasalts. Loose block near Shenval, Black Water GCR site (NJ 363 308). Coin is $20 \mathrm{~mm}$ diameter. (from Macdonald et al., 2005, figure 4.) (Photo: BGS No. P 582442, reproduced with the permission of the Director, British Geological Survey, (c) NERC.)

Figure 23 Map of the area around Auchindoun Castle, Glen Fiddich from BGS 1:10 000 sheets NJ33NW (1993) and NJ33NE (1993). The Portsoy Lineament lies some $4.5 \mathrm{~km}$ to the south-east of the castle. Most of the exposures of pelites in this area show square crosssections of chiastolite in hand specimen and thin sections reveal that this has been replaced by kyanite (Figure 24).

Figure 24 Chiastolite (=andalusite) porphyroblasts pseudomorphed by fan-like sheaves of kyanite in a sample of pelite from the Mortlach Graphitic Schist Formation close to Auchindoun Castle. The original 'crosses' formed by graphite inclusions in the chiastolite are still clearly visible. (from Beddoe-Stephens, 1990, figure 2a). (Photo: BGS No. P 254543, reproduced with the permission of the Director, British Geological Survey, (C) NERC.)

Figure 25 Map of the coastal strip between Cullen and Troup Head, based largely upon BGS 1:50 000 sheets 96W (Portsoy, 2002) and 96E (Banff, 2002). Late-Caledonian minor intrusions are omitted for clarity.

Figure 26 Cross-section of the coast between Cullen and Troup Head, based largely upon sections accompanying BGS 1:50 000 sheets 96W (Portsoy, 2002) and 96E (Banff, 2002). Key as in Figure 25.

Figure 27 Ripples on bedding surface in the Findlater Castle Quartzite at Findlater Castle. (Photo: BGS No. P 008614, reproduced with the permission of the Director, British Geological Survey, (c) NERC.)

Figure 28 View westwards from Portsoy Old Harbour towards Redhythe point. The rocks of the near and middle distance are mostly highly deformed semipelites, quartzites, metalimestones and graphitic pelites within the Portsoy Shear-zone; note the very strong, steeply plunging lineation in the quartzite on the left. The second promontory away from the camera consists of serpentinized peridotite, worked and sold locally as 'Portsoy Marble'. (Photo: J.R. Mendum, BGS No. P 001134.)

Figure 29 Andalusite porphyroblasts in the semipelitic part of the Knock Head Grit Member of the Macduff Slate Formation at Boyndie Bay. The hammer shaft is $35 \mathrm{~cm}$ long. (Photo: BGS No. P 221160, reproduced with the permission of the Director, British Geological Survey, (C) NERC.)

Figure 30 Quartzofeldspathic boulder, interpreted as a dropstone from a floating iceberg in the Macduff 'Boulder Bed', Macduff Slate 
Formation, The Sclates, Macduff. Professor Janet Watson provides a scale. (Photo: J.R. Mendum, BGS No. P 726598.)

Figure 31 Map of the coast section between Fraserburgh and Rosehearty, based upon the BGS 1:50 000 Sheet 97 (Fraserburgh, 1987). The diagrammatic cross-section is adapted from Loudon (1963) and is not to scale.

Figure 32 Refolded folds $(F 1+F 3)$ in a mixed sequence of thinly bedded calcareous semipelites, calcsilicate rocks and impure metalimestones of the Kinnaird's Head Formation at Kinnaird's Head, Fraserburgh.

(a) Tight F1 folds refolded by close to tight F3 folds, immediately east of the foghorn at NJ 998 677. A prominent S3 axial-planar cleavage and an L3 lineation are well developed in places. Hammer head is $16.5 \mathrm{~cm}$ long. (Photo: J.R. Mendum, BGS No. P 726599.)

(b) Refolded folds (F1 + F3), viewed to the east, at NJ 998676. Key fob is $4 \mathrm{~cm}$ in diameter. (Photo: D.J. Fettes, BGS No. P 726600$.

Figure 33 Cyclic bedding with graded units in the Rosehearty Formation. Andalusite is abundant in the finer-grained units. Note the cross-cutting cleavage. West of Sandhaven, NJ 952679. Key fob is $4 \mathrm{~cm}$ in diameter. (Photo: D.J. Fettes, BGS No. P 726601.)

Figure 34 Graded units with thin sandstone layers in a dominantly pelitic facies of the Rosehearty Formation. Abundant andalusite is clearly visible. Location as Figure 33 . Pen is $15 \mathrm{~cm}$ long. (Photo: D.J. Fettes, BGS No. P 726602.)

\section{Figure 35}

(a) Map of the Cairnbulg to st Combs coast section showing the textural varieties of migmatitic rocks within the Inzie Head Gneiss Formation. Modified after Johnson et al. (2001b). See text for explanations of the terminology.

(b) Map summarizing mineralogical characteristics of the leucosome element of the gneisses.

Figure 36 Schematic crustal section prior to D4 folding and uplift, showing the nature of migmatitic rocks in the Inzie Head Gneiss Formation and their relationships with the mid-Ordovician mafic and felsic intrusions. From Johnson et al. (2001b).

Figure 37 Cairnbulg Granite intruded into diktyonitic metatexite and nebulitic diatexite with relict metasedimentary schollen of the Inzie Head Gneiss Formation. Top of beach, south of Cairnbulg Harbour. The hammer shaft is $35 \mathrm{~cm}$ long. (Photo: J.R. Mendum, BGS No. P 726603.)

Figure 38 Schollen diatexites (L-gt zone), with large garnets now mainly retrogressed to chlorite in the Inzie Head Gneiss Formation. The calcsilicate lenses and psammites form metasedimentary schollen. The rocks were derived by anatectic partial melting of the dominantly semipelitic rocks. Point of Whitelinks, east of 
Inverallochy, Cairnbulg to St Combs GCR site. The hammer shaft is $35 \mathrm{~cm}$ long. (Photo: J.R. Mendum, BGS No. P 726604.)

Figure 39 Map of the Collieston to Whinnyfold coast section showing D1 and D3 structural elements, adapted from Mendum (1987). The inset equal-area stereographic projection shows structural elements of the section between Whinnyfold and old Castle.

Figure 40 Composite cross-section of the coast section between Collieston and Whinnyfold, showing the overall fold pattern in a plane normal to the fold axes. From Mendum (1987).

Figure 41 An excellent example of a recumbent, east-facing F1 fold in dominantly inverted gritty psammites of the collieston Formation, viewed towards the north-north-east. Devil's Study, Collieston to Whinnyfold coast section. J.R. Mendum provides a scale. (Photo: BGS No. P 002878, reproduced with the permission of the Director, British Geological Survey, (c) NERC.) 
Figure $6.2 a$

Group

Glen Tilt to Glen Shee

Deeside

\begin{tabular}{l} 
\\
\hline SOUTHERN \\
HIGHLAND
\end{tabular}

Group in this area see Chapter 4

HIGHLAND

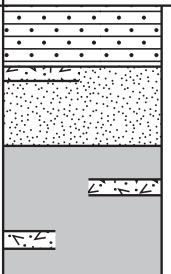

$\mathrm{CCCC}$

$\operatorname{ccccc}$

C C C

Tayvallich

ביד

Loch Tay Limestone Fm

(1)

\begin{tabular}{|c|c|c|}
\hline Tayvallich & $\begin{array}{c}c c c \\
c c c c c c \\
c c c c c\end{array}$ & Loch Tay Limestone Fm \\
\hline & $\begin{aligned}= \\
==1 \\
=\end{aligned}$ & Ben Lui Schist Formation \\
\hline
\end{tabular}

(mostly Duchray Hill

Gneiss Member)

\section{ARGYLL}

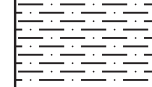

\section{(}

(a)

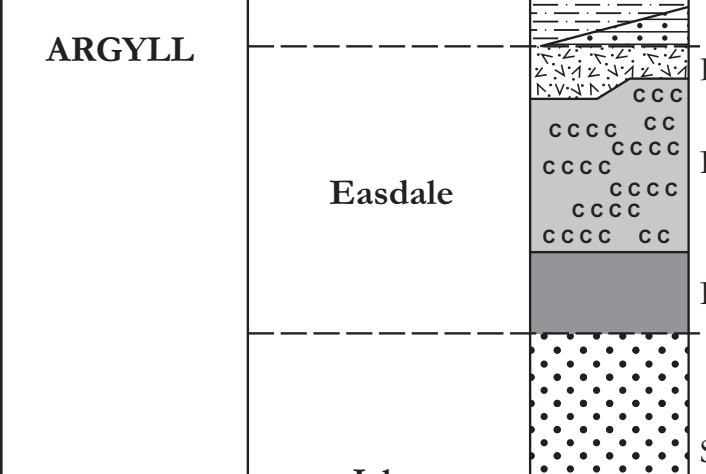

Islay

Schiehallion/Creag Leacach

Ben Eagach Schist Fm

Ben Lawers Schist Fm

Ben E- ------

\begin{tabular}{|c|c|c|c|}
\hline & Islay & $\because \because \because \because \because \because$ & $\begin{array}{l}\text { Schiehallion/Creag Leacach } \\
\text { Quartzite Fm }\end{array}$ \\
\hline \multirow{5}{*}{ APPIN } & \multirow{2}{*}{$\begin{array}{l}\text { Blair } \\
\text { Atholl }\end{array}$} & \begin{tabular}{|l}
$\operatorname{cccc} \operatorname{cc}$ \\
$\operatorname{cccccccc}$ \\
$\operatorname{cccc} c$ \\
\end{tabular} & Gleann Beag Schist Fm \\
\hline & & & 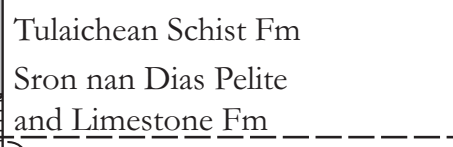 \\
\hline & \multirow[t]{3}{*}{ Ballachulish } & $\begin{array}{r}\text { c c c c } \\
\text { c c c } \\
\\
\end{array}$ & $\begin{array}{l}\text { Glen Loch Phyllite and } \\
\text { Limestone Fm }\end{array}$ \\
\hline & & & An Socach Quartzite Fm \\
\hline & & & $\begin{array}{l}\text { Beinn a Ghlo Transition Fm } \\
\text { Glen Clunie Graphitic Schist Fm }\end{array}$ \\
\hline
\end{tabular}

position of Loch Tay Fault

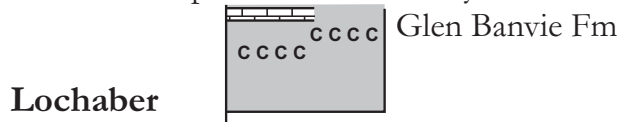

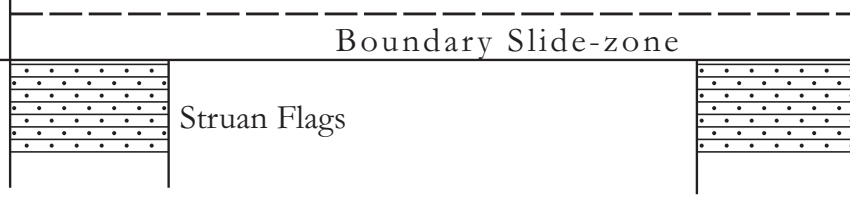

Water of Tanar Limestone/

Deeside Limestone Fm

Queens Hill Fm

Balnacraig Metabasite

Member Coyles of Muick $=$

Meall Dubh Metabasite Fm

Glen Girnock Calcareous Fm

Creag nam Ban Psammite Fm/

Glas Maol Graphitic Schist Fm

Cairn of Claise Transition Fm

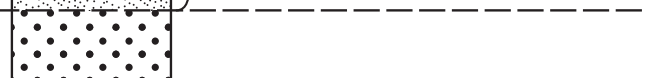

$\because \because \because \because \because$ Creag Leacach Quartzite Fm

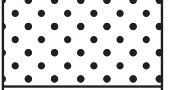

$\because \because \bullet$ Sron na Gaoithe Boulder Bed

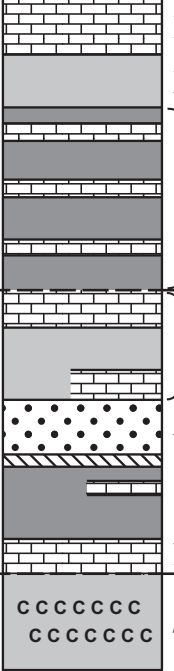

Rimarsin Limestone Fm

Lawsie Psammite Fm

Tomite Fm

Crathie Schist and

Limestone Fm

Birchwood Semipelite Fm

An Socach Quartzite Fm

(Transition)

Glen Clunie Graphitic Schist Fm

Baddoch Burn Dolomite Member

Tom Anthon Mica-schist Fm 


\section{Strathdon, Tomintoul,}

Dufftown, Huntly
North coast and

Turriff Syncline
North-east coast and

\section{Buchan Anticline}

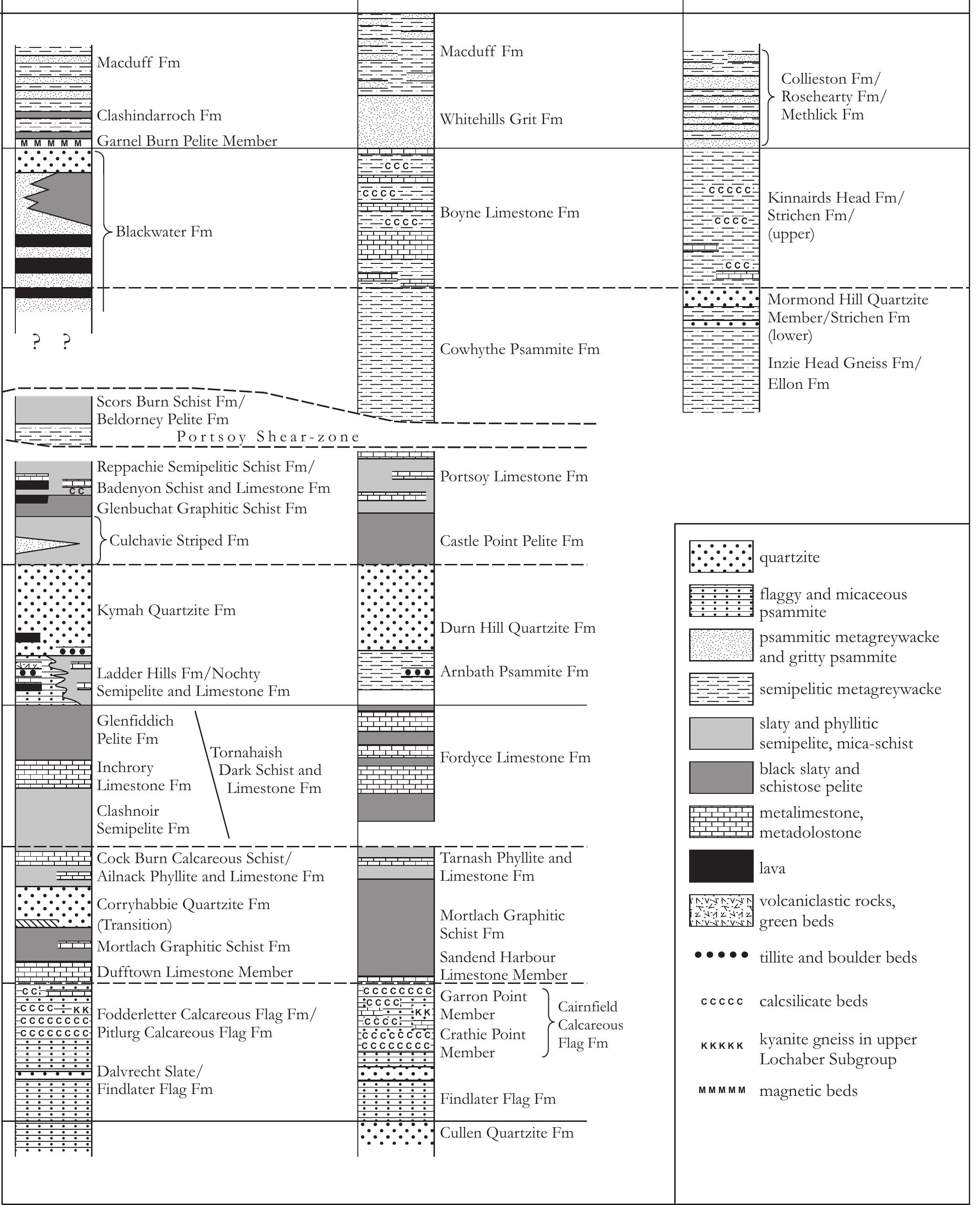




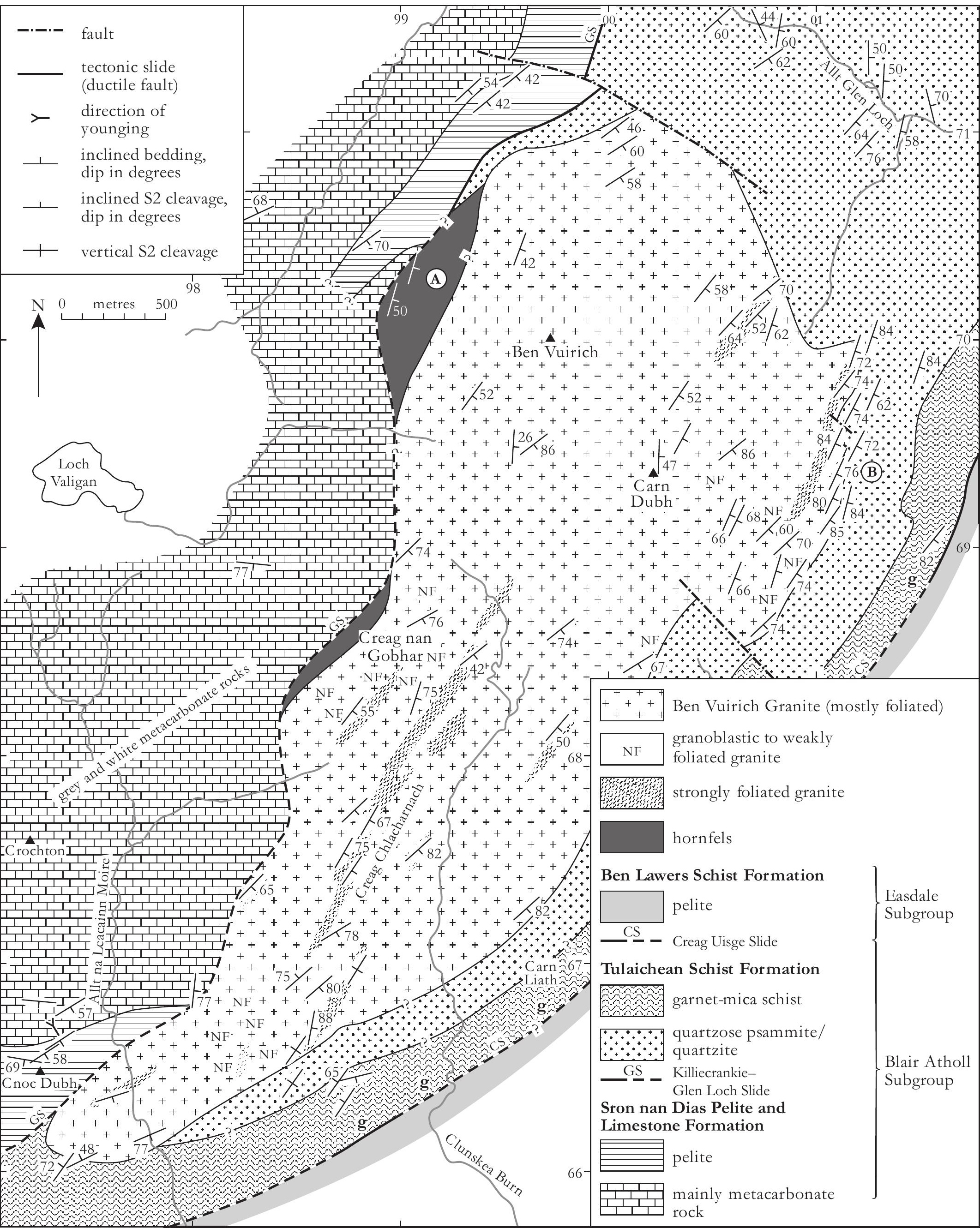




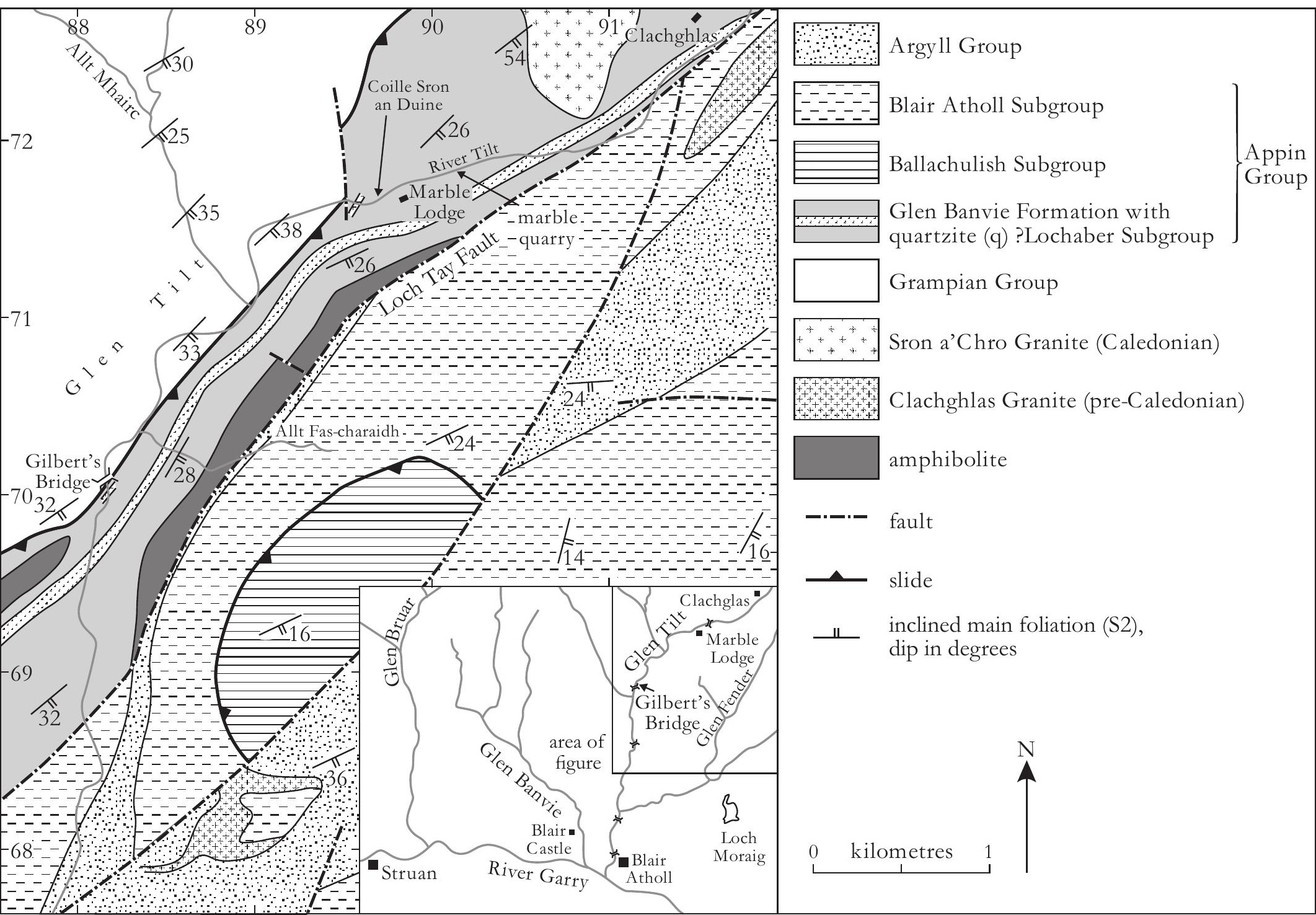


NW

\section{Easdale Subgroup}

Islay Subgroup

\section{Blair Atholl Subgroup}

\section{Ballachulish Subgroup}

Pros

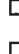

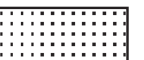

\section{An Socach Quartzite and Beinn a'Ghlo}

Transition formations

Glen Clunie Graphitic Schist Formation

\section{Lochaber Subgroup}

Tom Anthon Mica Schist Formation

\section{Grampian Group}

Struan Flags
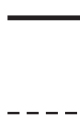

-ーーー

- - - F4 axial trace

$\longrightarrow$ F1 facing

AE Allt Elrig-Carn Aosda fold trace (F2)

AL Altanour Lodge fold trace (F2)

AS An Socach fold trace (F2)

B Baddoch Burn fold trace (F2)

BBS Baddoch Burn-Morrone Slide (D2)

BS Boundary Slide (D2)

C Cairnwell-Gleann Beag fold trace (F1)

DE Devil's Elbow fold trace (F4)

M Morrone fold trace (F2) 


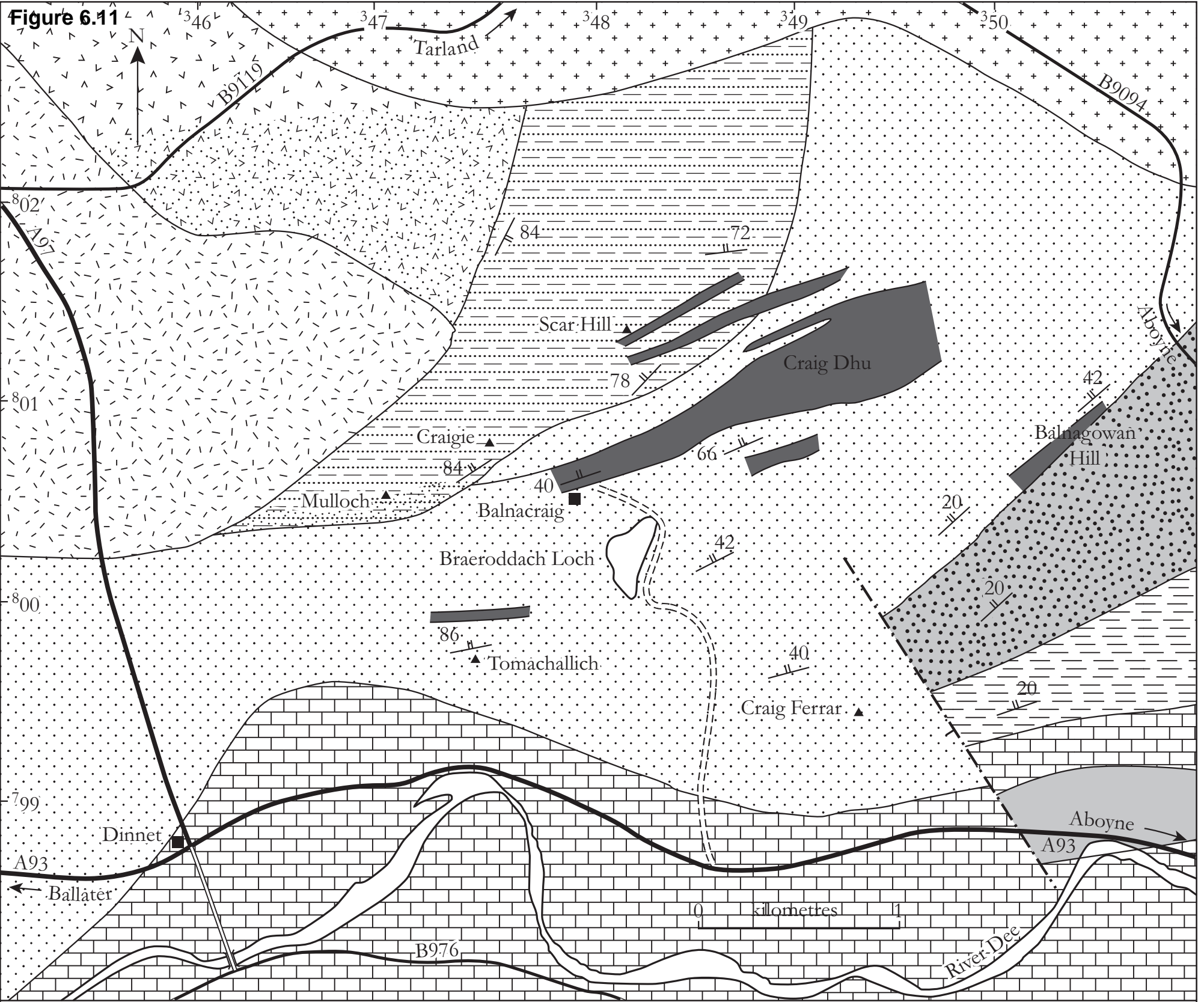

\section{Silurian-Devonian}

$\left[+{ }_{++}^{+}++\right.$Tomnaverie Granodiorite

$\therefore$ Logie Coldstone Tonalite

Ordovician

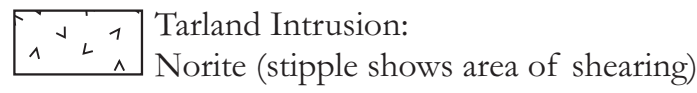

\section{Neoproterozoic}

amphibolite: metamorphosed tholeiitic sheets

Deeside Limestone Formation: calcsilicate rock and

metalimestone with beds of psammite and minor semipelite

Queen's Hill Formation

E三三 psammite with minor semipelite layers

$\because \because \because \because$ pelite and semipelite, coarse grained,

$\therefore \because \because \because$ with large feldspar porphyroblasts

$\because \because \because$ mixed psammite, semipelite and pelite,

becoming poorly foliated and xenolithic in patches

…......... heterogeneous xenolithic gneiss of metasedimentary origin

(stipple shows area of shearing and retrogression)

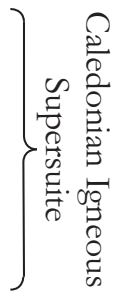

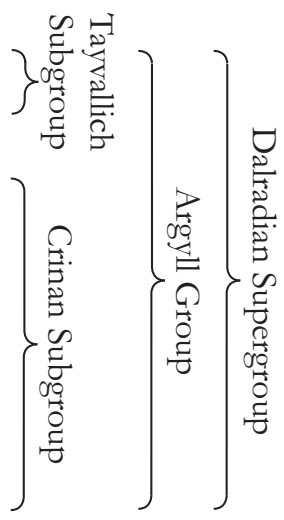

geological boundary

- - - fault, with sense of displacement shown by tick

_ـ inclined gneissose foliation, dip in degrees

$\mathrm{NB}$ in this area, all of the Neoproterozoic rocks are migmatitic

road 


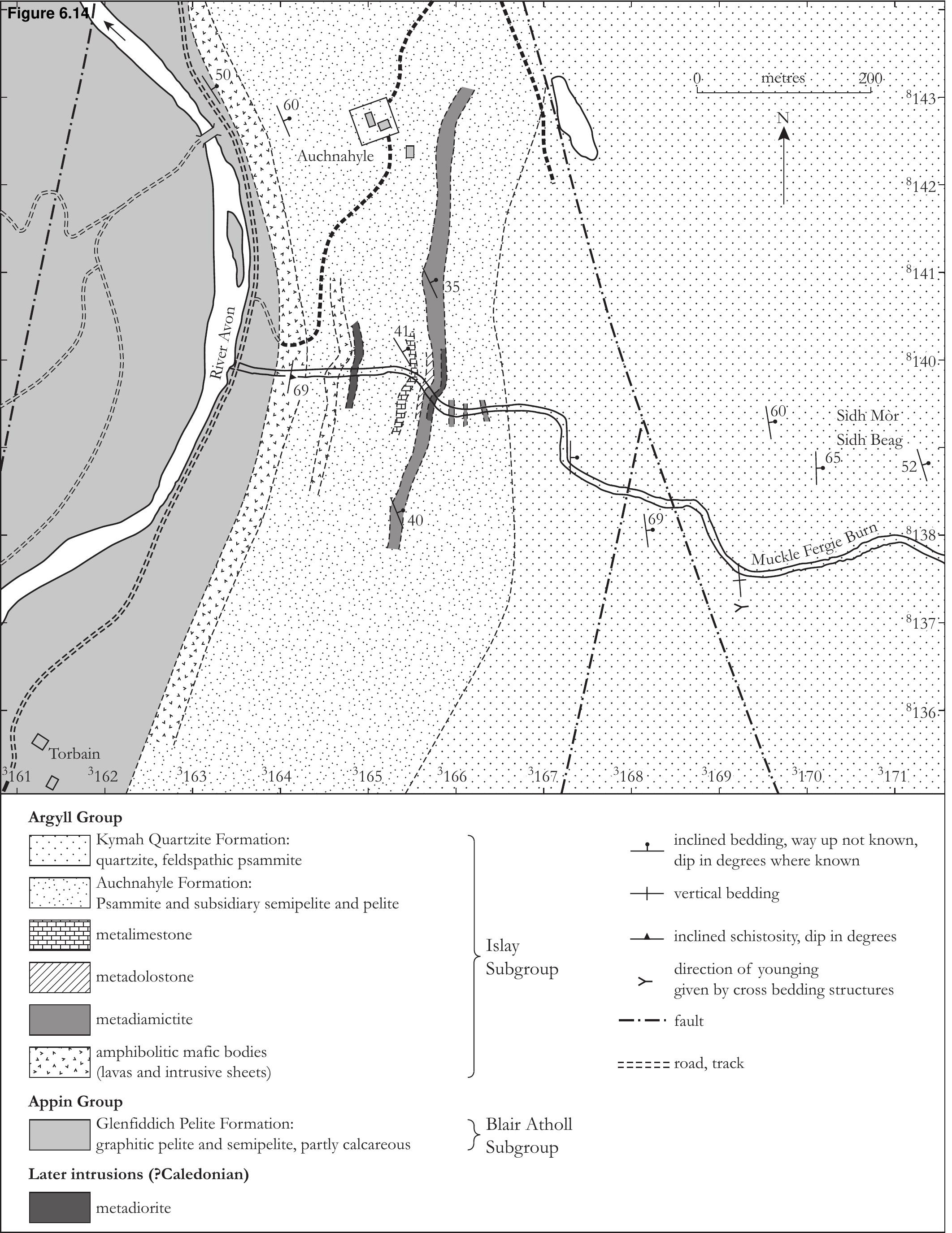


NW

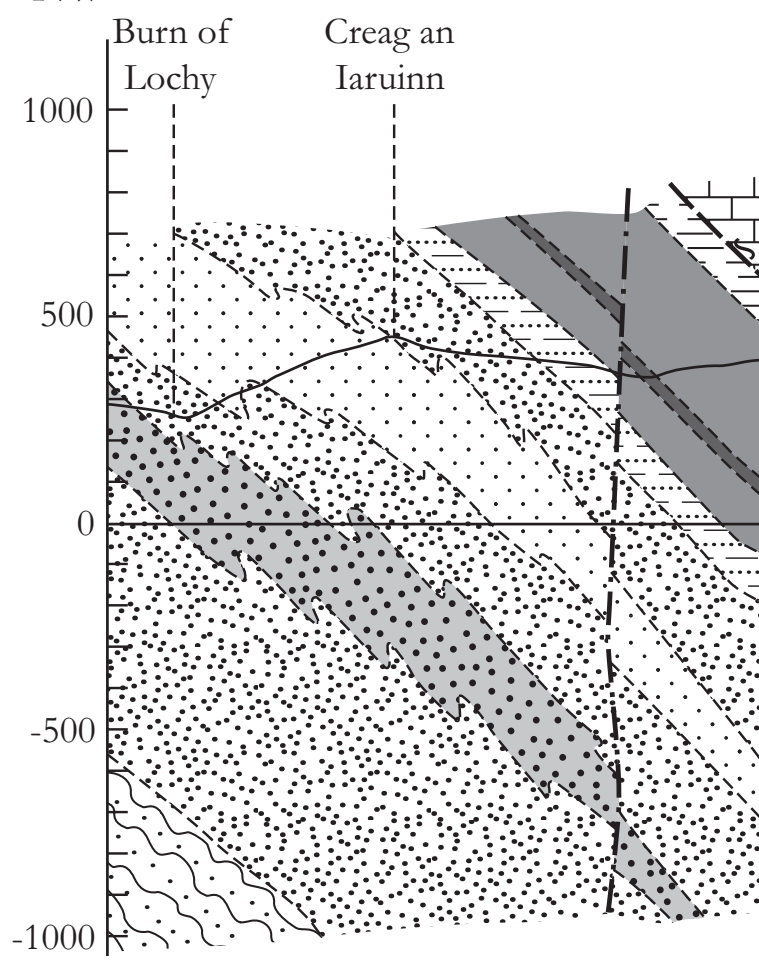

SE

\section{Old Red Sandstone Supergroup}

Tomintoul Group (late Silurian or Early Devonian) $\therefore \because$ Delnabo Conglomerate Formation

\section{Dalradian Supergroup (Neoproterozoic) Appin Group}

Blair Atholl Subgroup
$\square$ Glenfiddich Pelite Formation

Inchrory Limestone Formation

Ballachulish Subgroup

Ailnack Phyllite and Limestone Formation

$\because \because \therefore \therefore$ Corriehabbie Quartzite Formation

$=\overline{-}$ Mortlach Graphitic Schist Formation

Lochaber Subgroup

\begin{tabular}{|c|c|}
\hline & $\begin{array}{l}\text { Fodderletter Calcareous Flag Formation } \\
\text { Fireach Beag Kyanite Gneiss Member } \\
\text { in middle part }\end{array}$ \\
\hline & Dalvrecht Slate Formation \\
\hline
\end{tabular}

\section{Grampian Group}

Tormore Psammite Formation

Strathavon Psammite Member

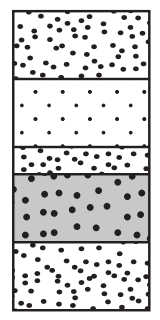

feldspathic psammite quartzite feldspathic psammite mixed psammite and semipelite psammite

Cromdale Hills Quartzite Member

- - - fault

ーニー slide 
Figure $6.20 a_{+}$

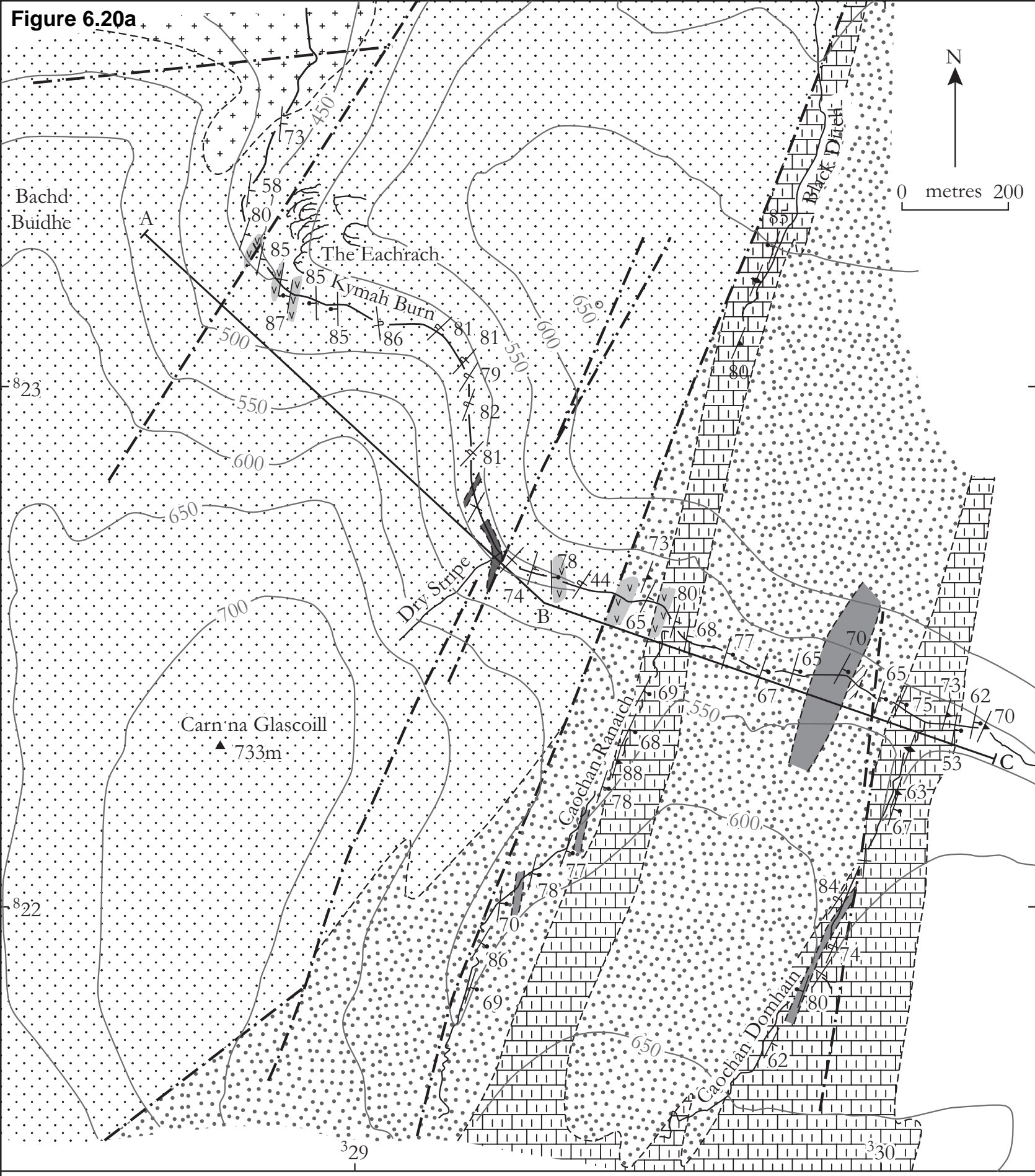

Late-Caledonian Igneous Rocks

${ }_{+}^{+}+{ }_{+}^{+}++$microgranite (part of Glenlivet Granite Pluton)

\section{Argyll Group}

Islay Subgroup

$\therefore \because \therefore$ Kymah Quartzite Formation

11 Nochty Semipelite and Limestone Formation

metabasalt (possibly lava)

metavolcaniclastic rocks
Ladder Hills Formation

1 inclined bedding, dip in degrees

$\rightarrow$ inclined bedding, known to be overturned, dip in degrees

- inclined bedding, way up not known, dip in degrees

+ vertical bedding

— inclined cleavage, dip in degrees

$\multimap$ vertical cleavage

$>$ direction of younging

- - - fault 


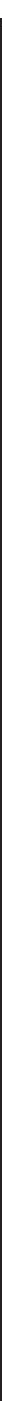




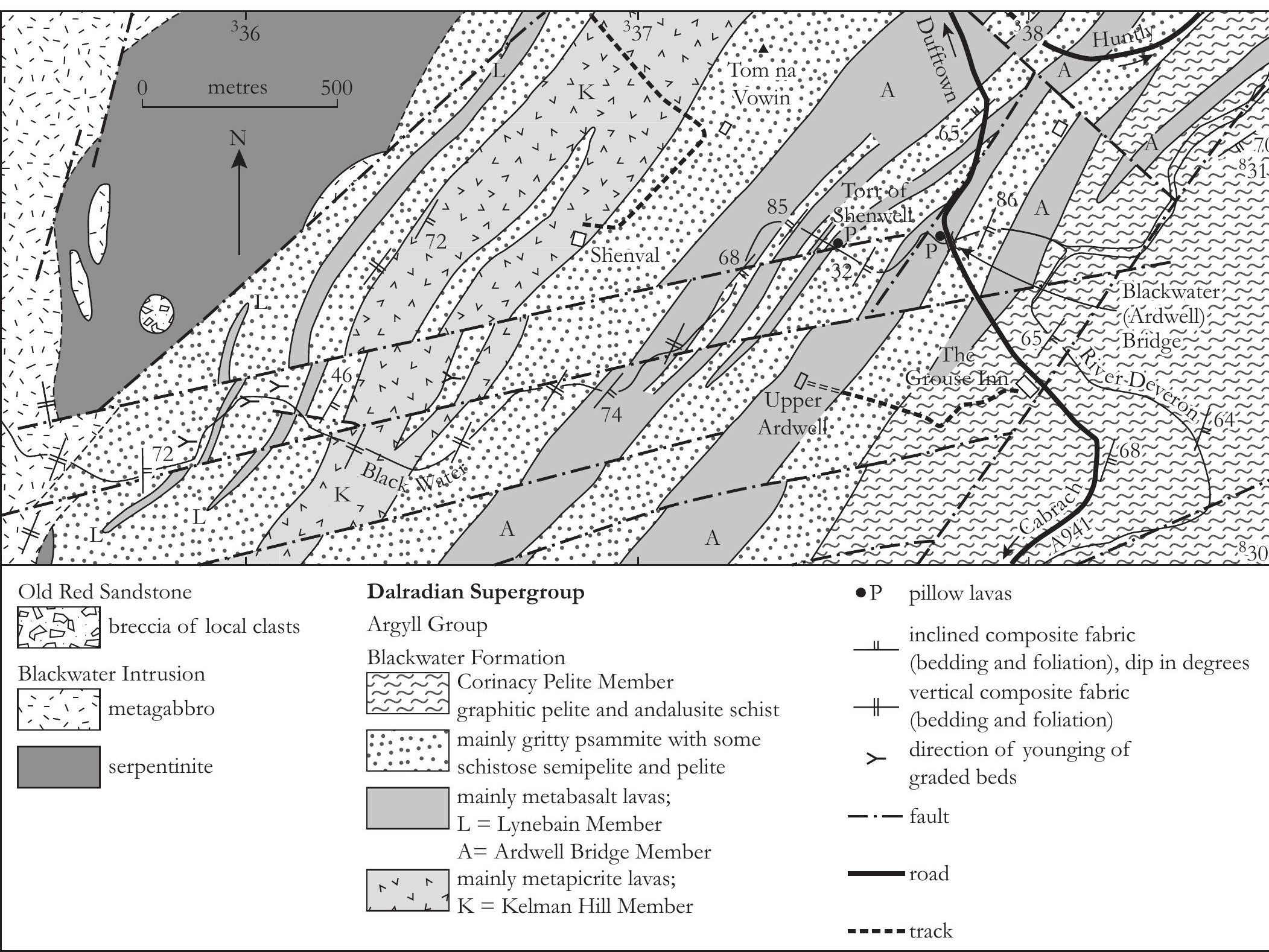




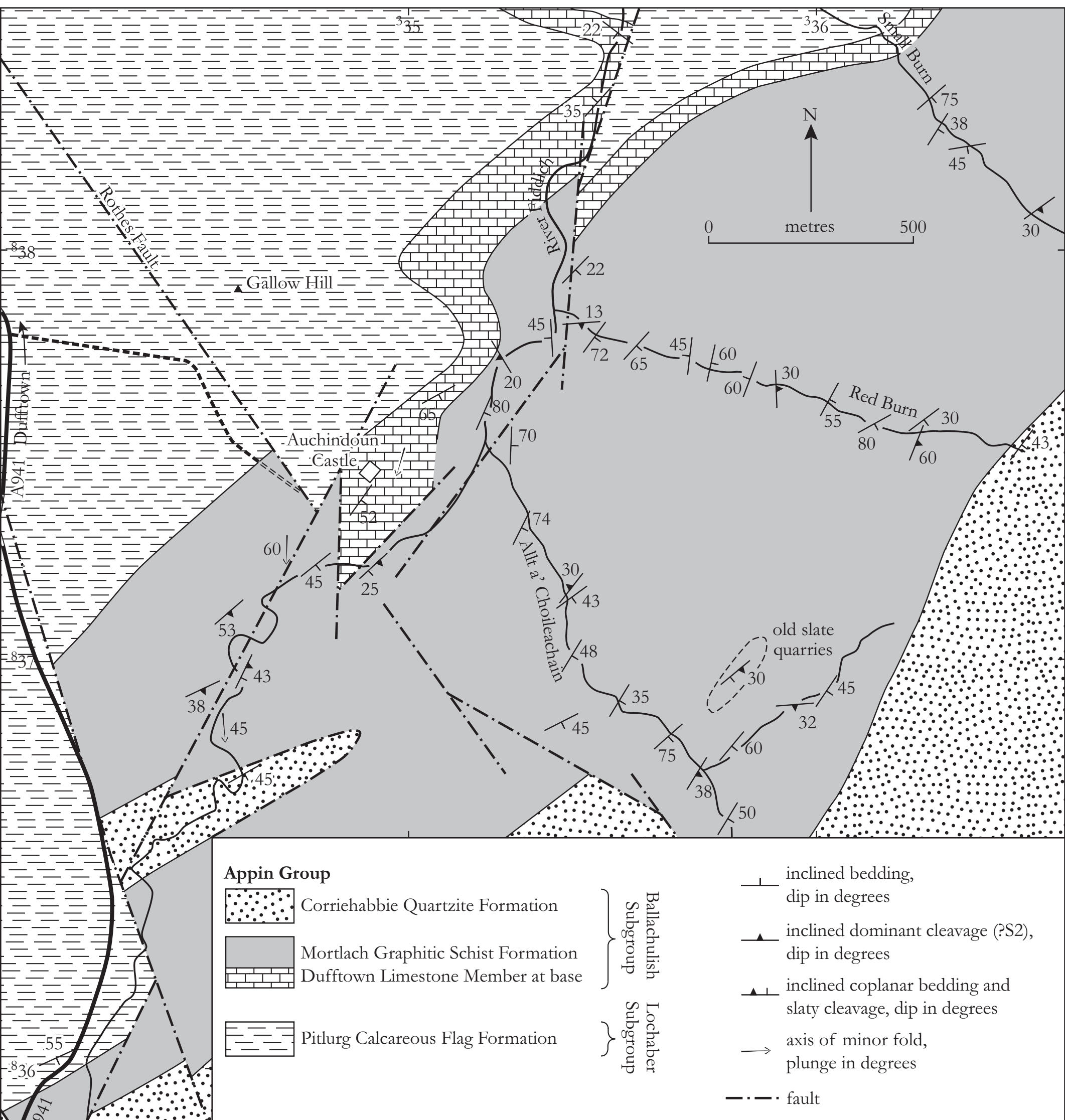

road 
Figure 6.25

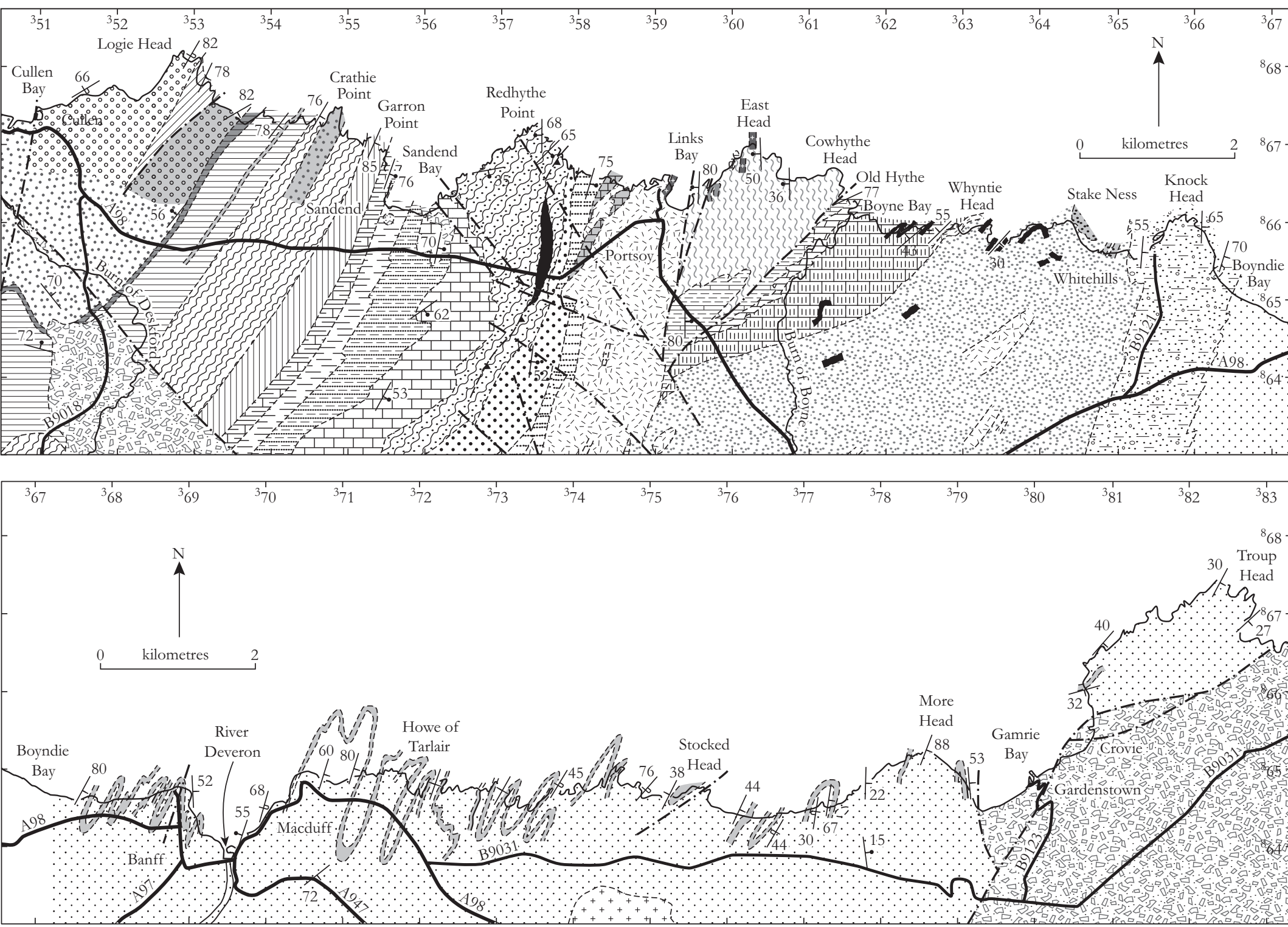


Old Red Sandstone Supergroup

\section{Pand}

Dalradian Supergroup (Neoproterozoic)

\section{Southern Highland Group}

\section{\begin{tabular}{l}
$\therefore$ \\
$\therefore$ \\
\hdashline \\
$\therefore$
\end{tabular}}

Macduff Formation,

showing prominent psammite units

Knock Head Grit Member

Whitehills Grit Formation,

showing calcareous gritty psammite and lower gritty psammite units (in cross-section only)$$
\text { - }
$$ \\ \begin{tabular}{|l}
\hline 111 \\
\hline 111 \\
\hline 1 \\
\hline-1 \\
\hline-1 \\
\hline-
\end{tabular}}

Argyll Group

Tayvallich Subgroup Crin II
II
$=-1$
$=-1$
Crin
? ?
? Whyntie Brae Calcsilicate Member Boyne Castle Limestone Member Old Hythe Semipelite Member Boyne Limestone Formation

\section{$\sqrt{2}$}

Cowythe Psammite Formation, including prominent metalimestone unit

Easdale Subgroup Portsoy Limestone Formation

……............. Castle Point Pelite Formation, including related semipelitic and pelitic rocks Islay Subgroup $\because \because \because \because$ Durn Hill Quartzite Formation

\section{Appin Group}

Blair Atholl Subgroup

BrI Fordyce Limestone Formation.

includes prominent metalimestone unit, shown in the cross-section only

Ballachulish Subgroup

....$\quad$ Tarnash Phyllite and Limestone Formation.

- includes the Linkbrae Limestone Member

(shown in the cross-section only)

$\bar{\equiv} \bar{\equiv}$ Mortlach Graphitic Schist Formation

Sandend Harbour Limestone Member

Lochaber Subgroup

Faron Point Tremolitic
Findlater Flag Formation.
includes Findlater Castle
Quartzite Member
West Sands Mica Schist Member

\section{Grampian Group}

$\because \therefore \because \therefore$ Cullen Quartzite Formation (undivided)

$\because \because \because 0$ Sunnyside Psammite Member

Dicky Hare Semipelite Member

$\because \because \because 0$ Logie Head Quartzite Member
Intrusive Igneous Rocks

${ }_{+{ }_{+}^{+}+{ }_{+}^{+}+{ }_{+}^{+}}$Longmanhill Granite (Ordovician)

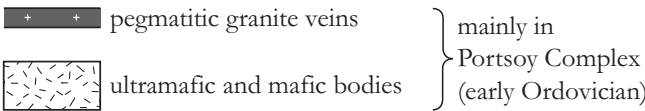

amphibolitic mafic sheets and dykes (mainly early Ordovician)

Portsoy Granite (Neoproterozoic)

I. inclined bedding,

1 dip in degrees

- inclined bedding known to be overturned, dip in degrees

$+\quad$ inclined bedding, way up not known, dip in degrees

$\uparrow$ vertical bedding

-----. geological boundary

-.- fault

- $\mathbf{A}$ thrust

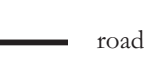


Figure 6.26
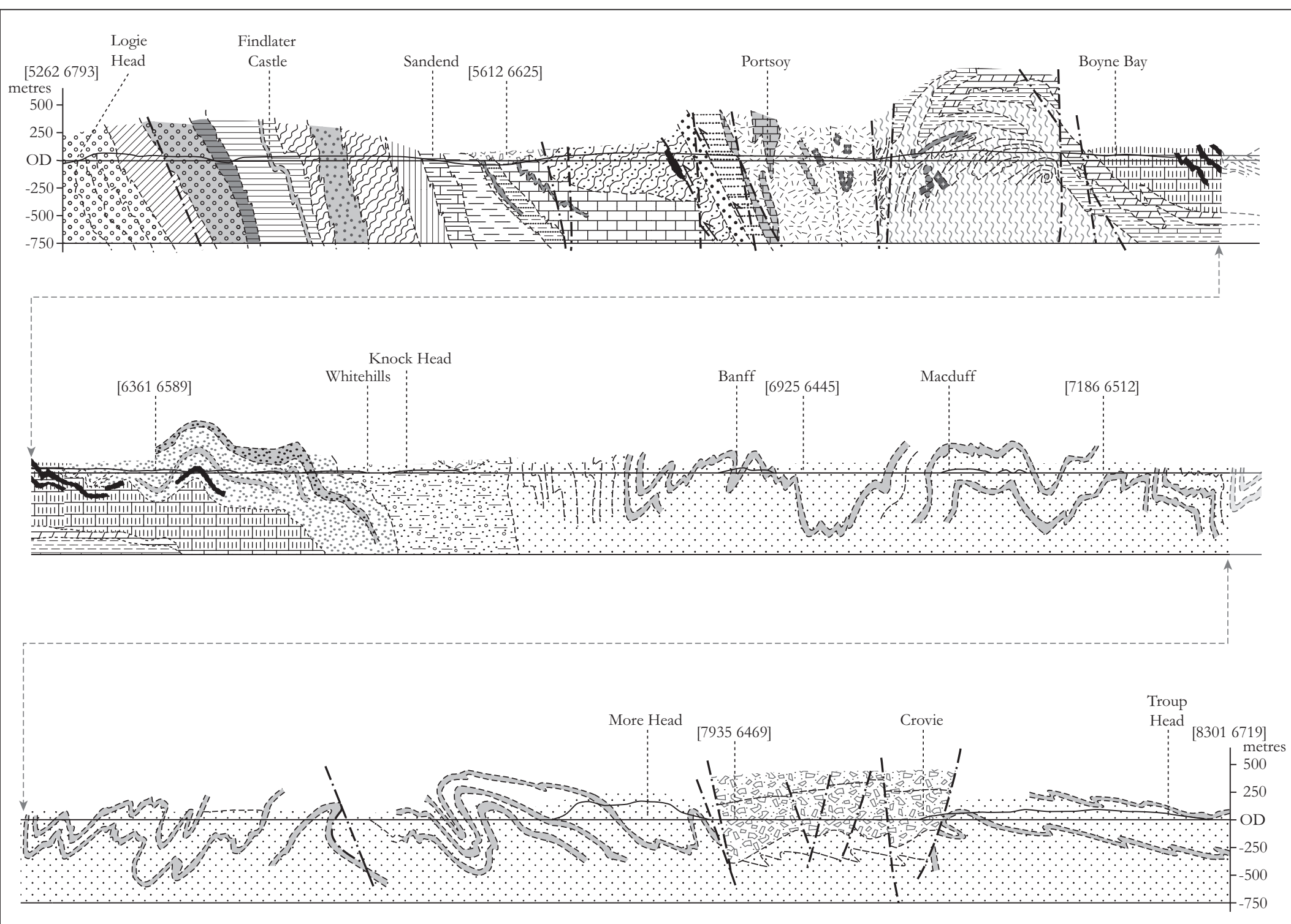
Figure 6.31

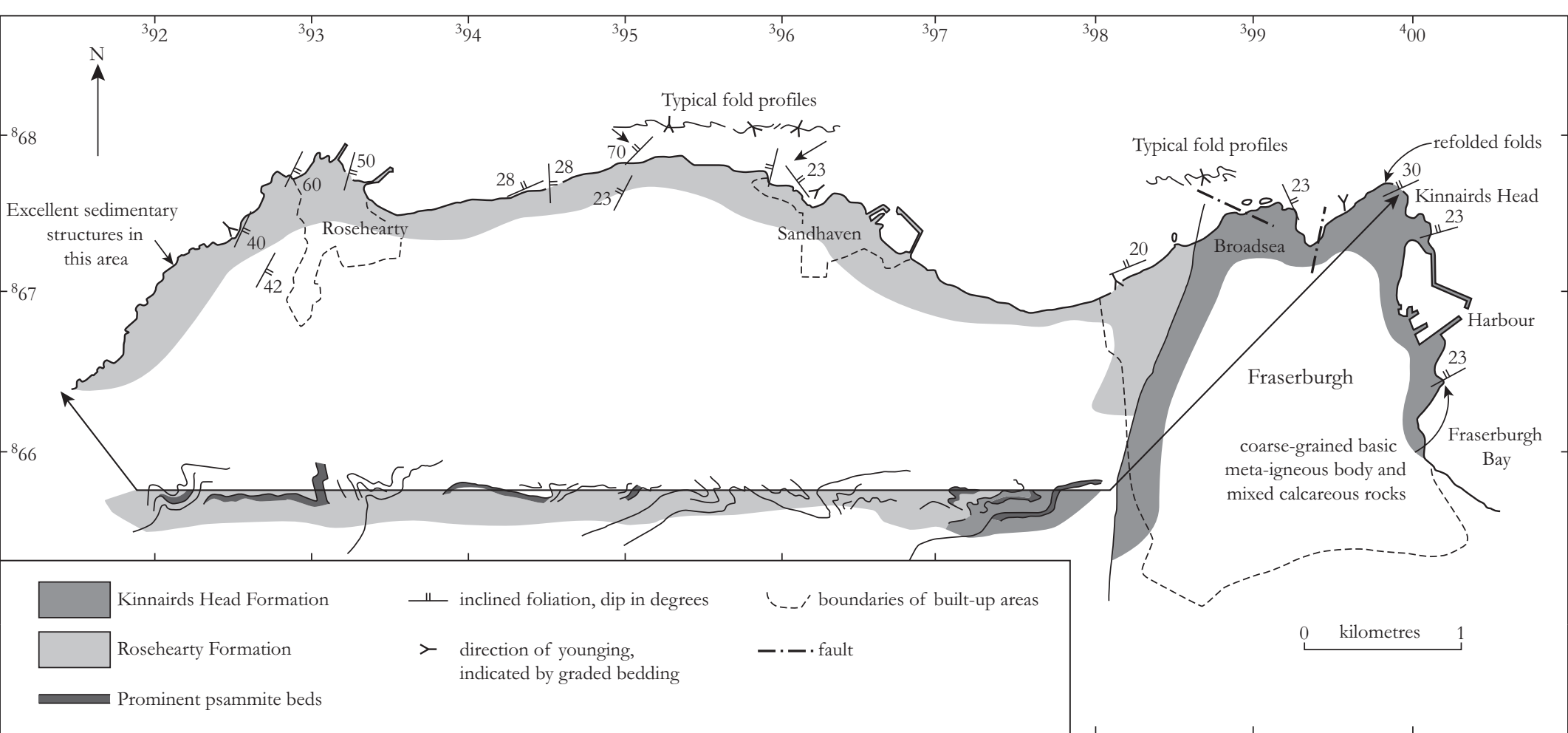


Figure 6.35

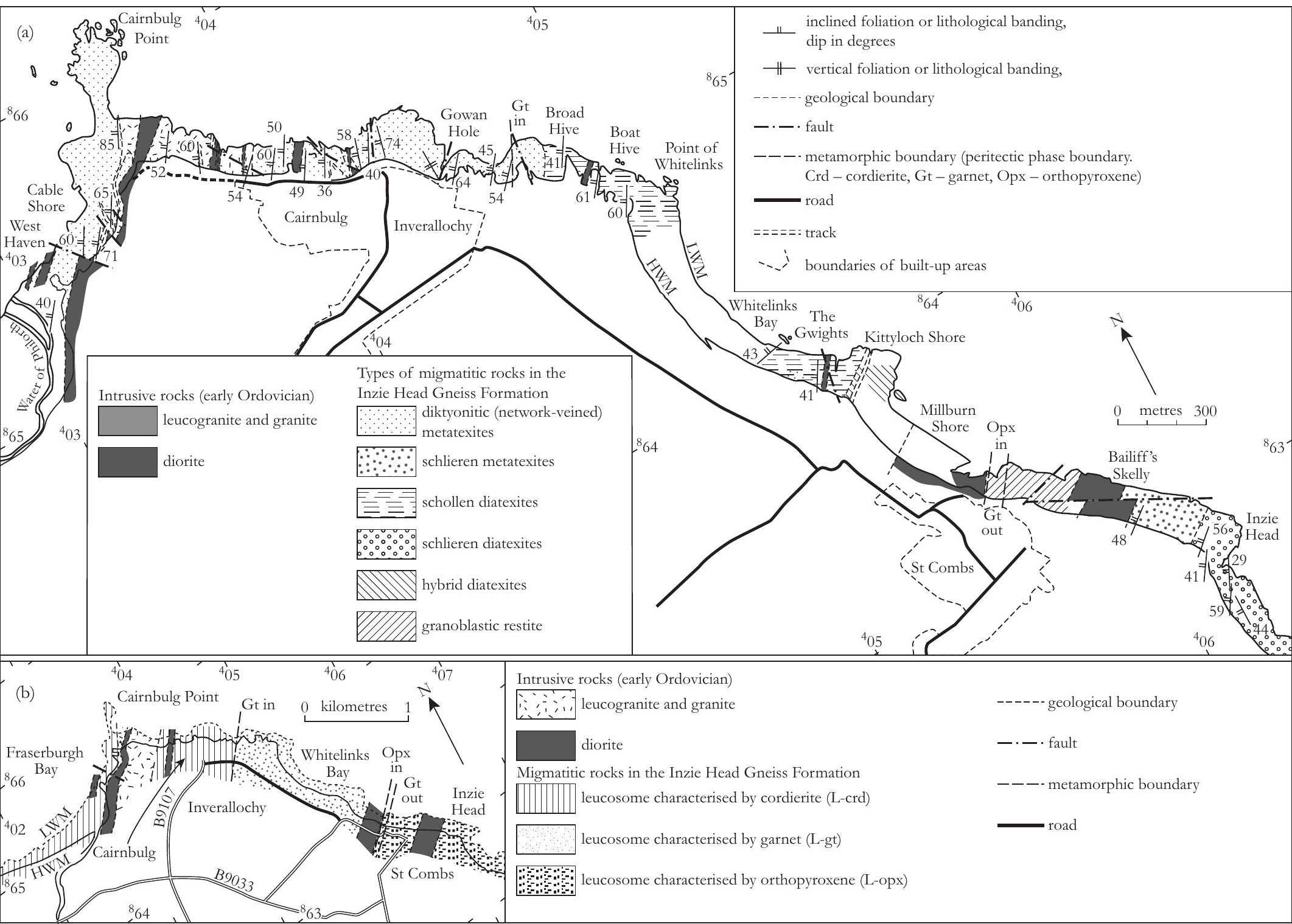


Figûre 6.36

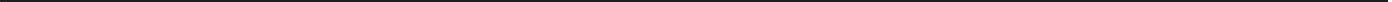


Figuke 6.39

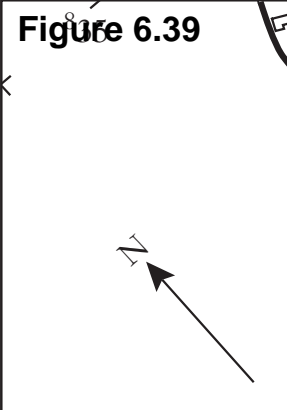

0 metres 500

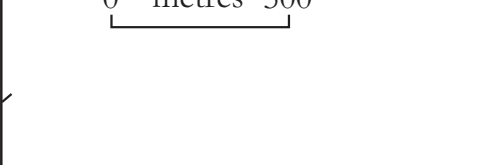

oil pipeline booster station

1
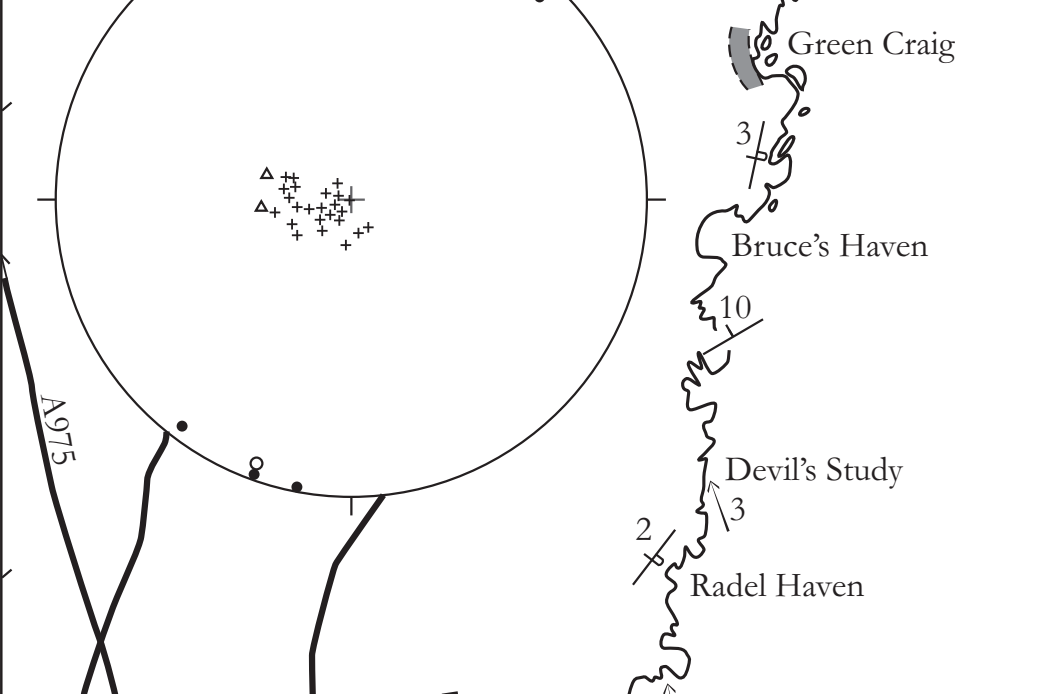

(
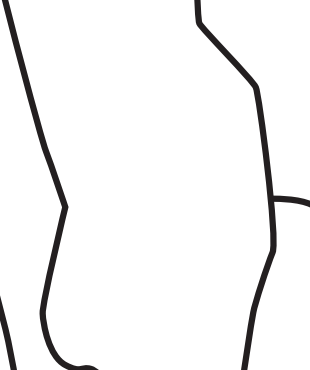

品

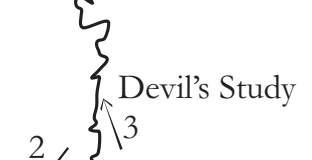

$\left\{\begin{array}{l}3 \\ 3\end{array}\right.$

Radel Haven
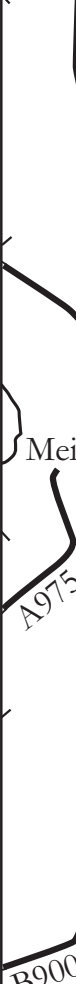

Cotehill Loch
${ }^{8} 33$

$+_{++}^{+}+{ }_{+}^{+}+$Peterhead Granite (late Caledonian) metadolerite sheets

${ }^{4} 09$

Southern Highland Group

Collieston Formation

geological boundary

inclined bedding, right way up, dip in degrees

-7 inclined bedding, inverted, dip in degrees

$\stackrel{5}{\longrightarrow}$ axis of F1 minor fold, plunge in degrees

${ }^{4} 08$

Bo buildings (mainly farm buildings)

\section{Stereogram}

- $\quad$ F1 fold axis

$\circ \quad$ F3 fold axis

${ }^{4} 07$

$+\quad$ pole to S1 cleavage and/or F1 axial plane

$\Delta \quad$ pole to S3 cleavage and/or F3 axial plane 


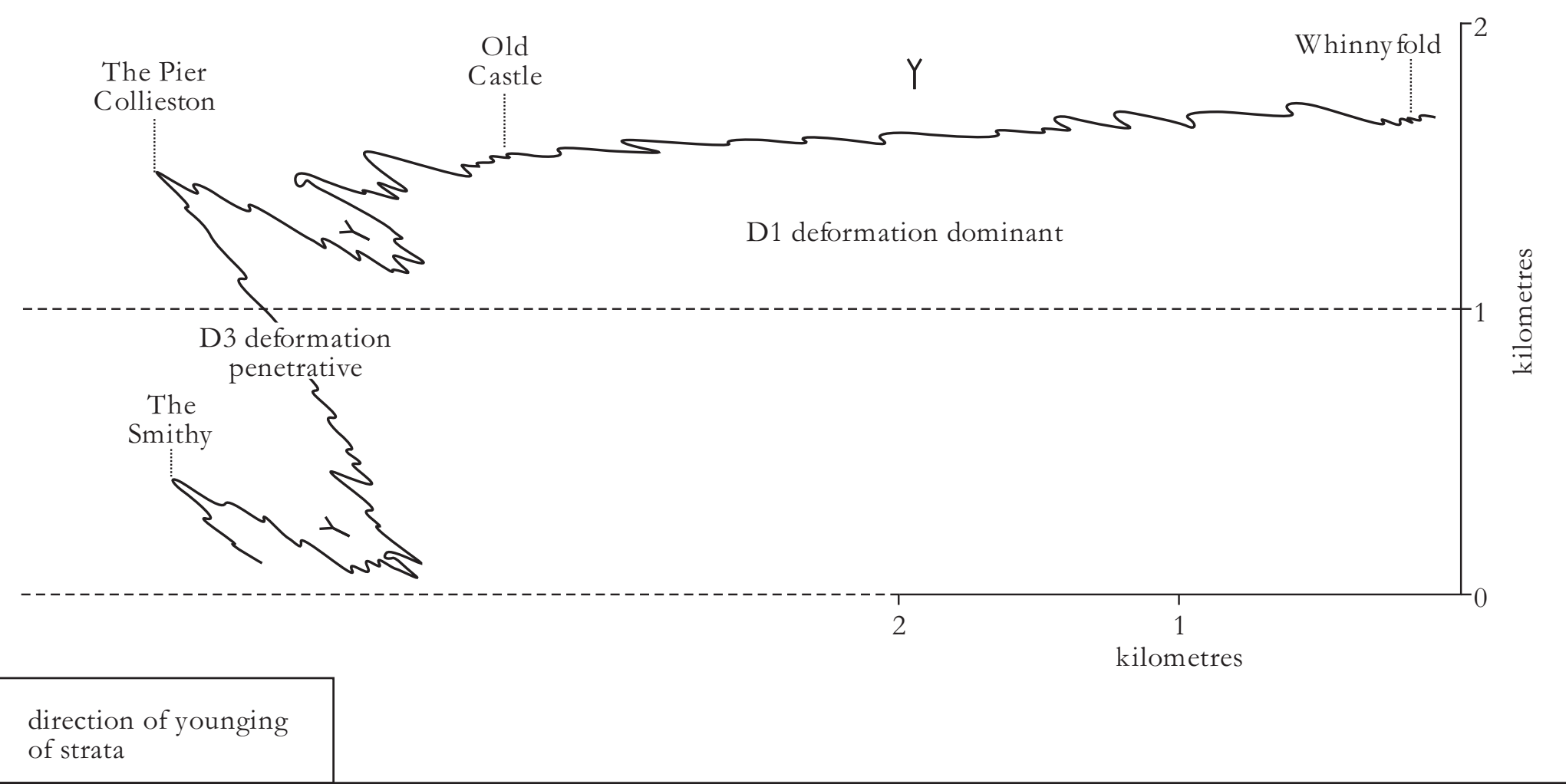


Click here to download high resolution image

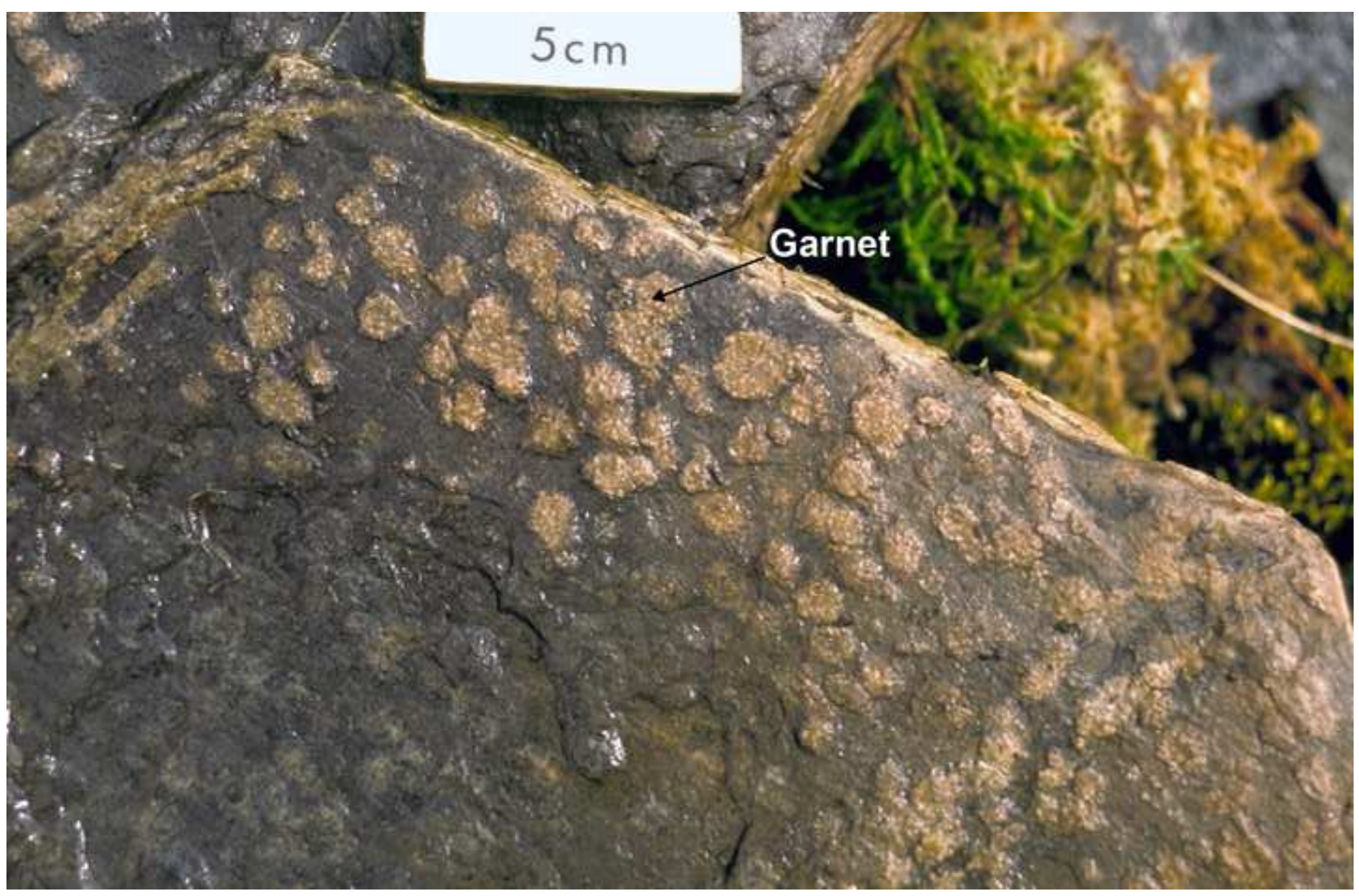


Click here to download high resolution image

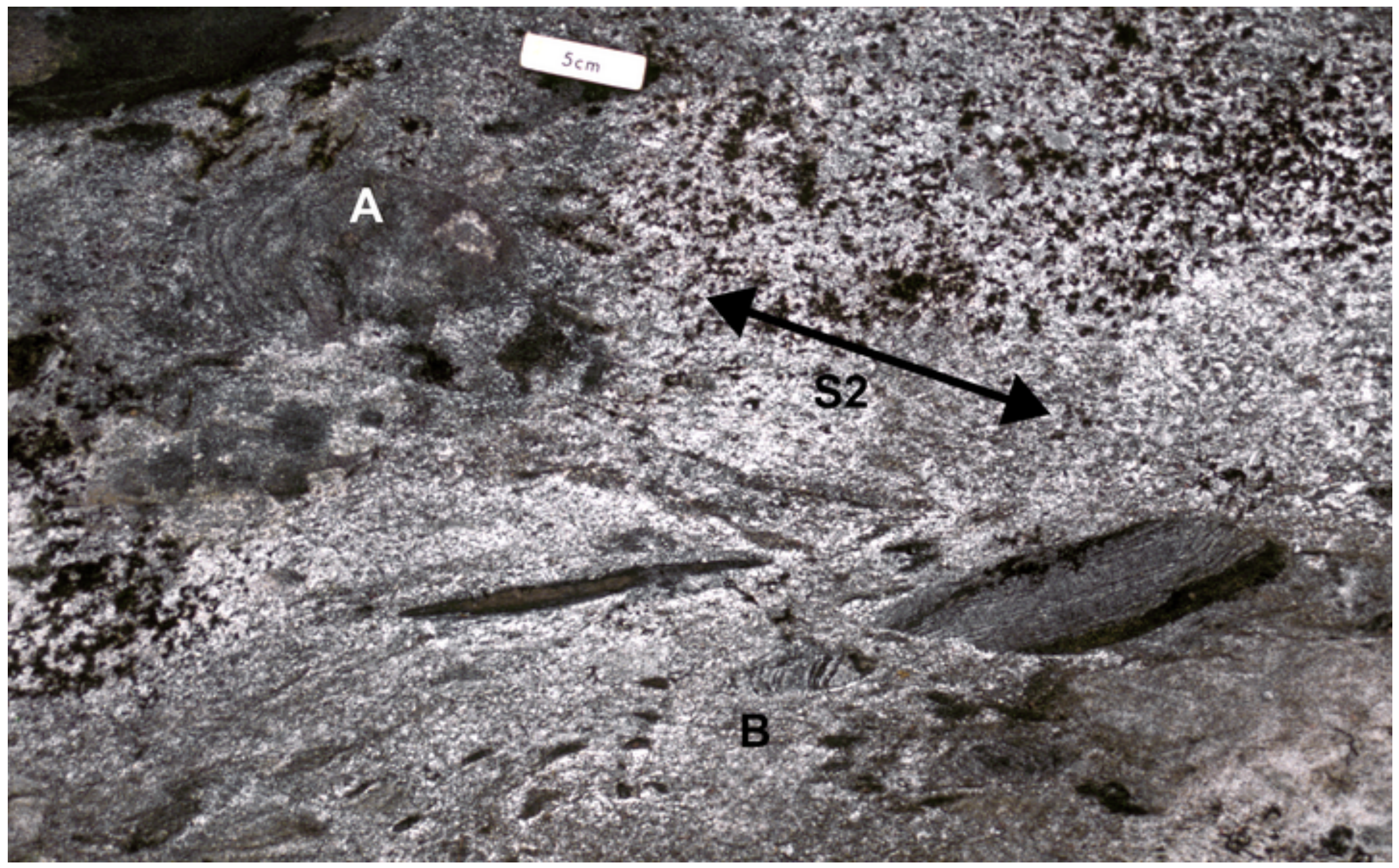




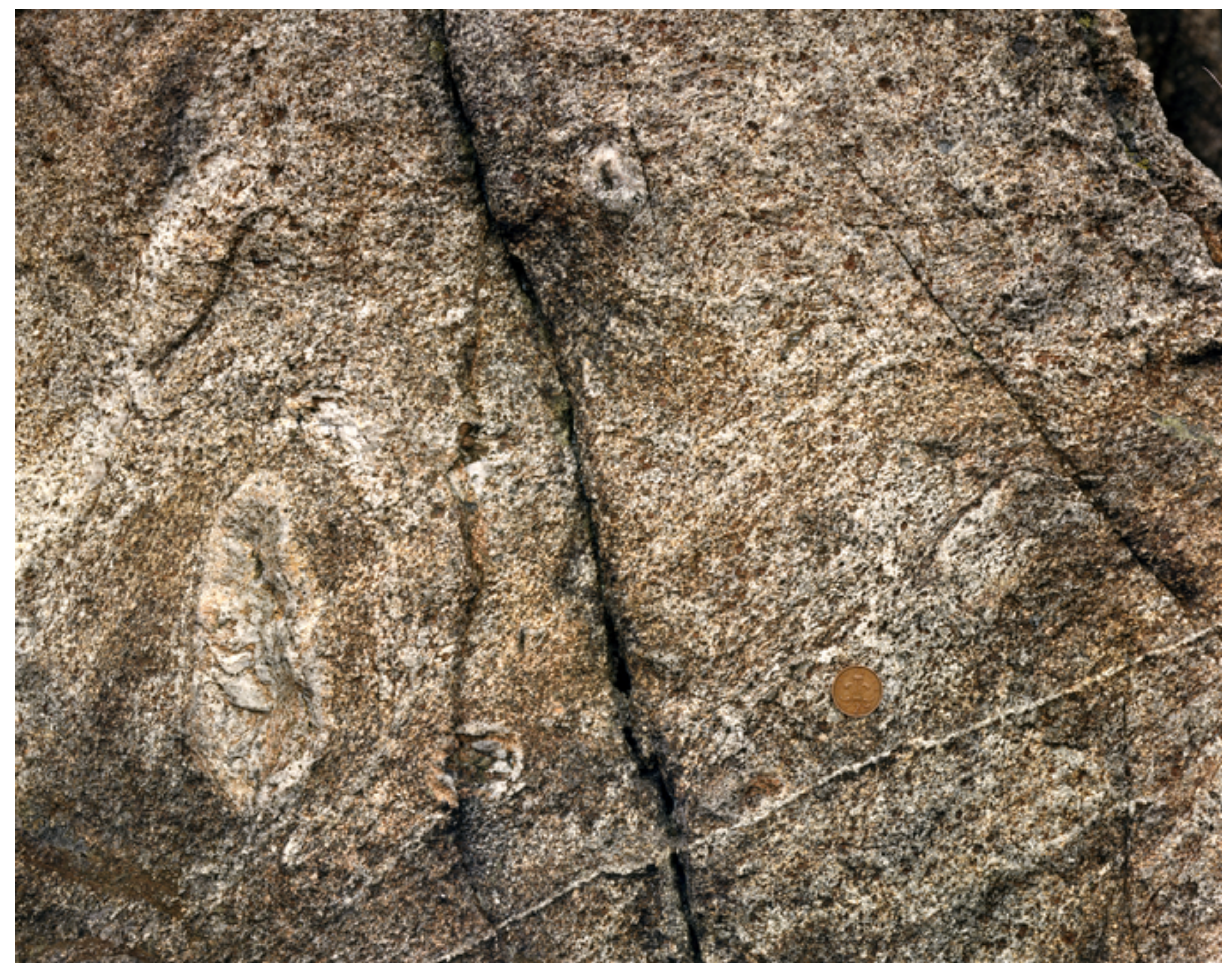 \\ Click here to download high resolution image}




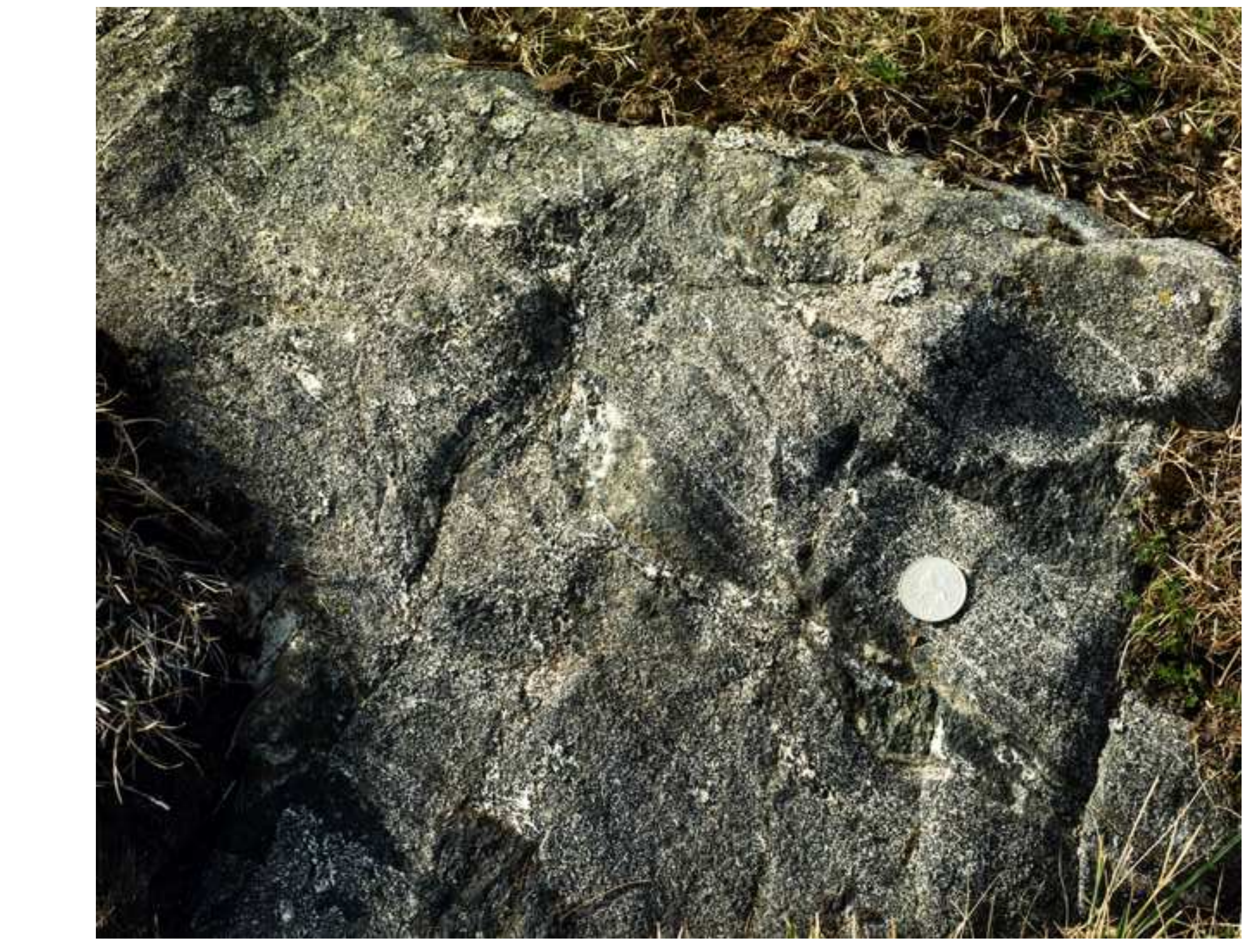

\section{Click here to download high resolution image}

$-$ 


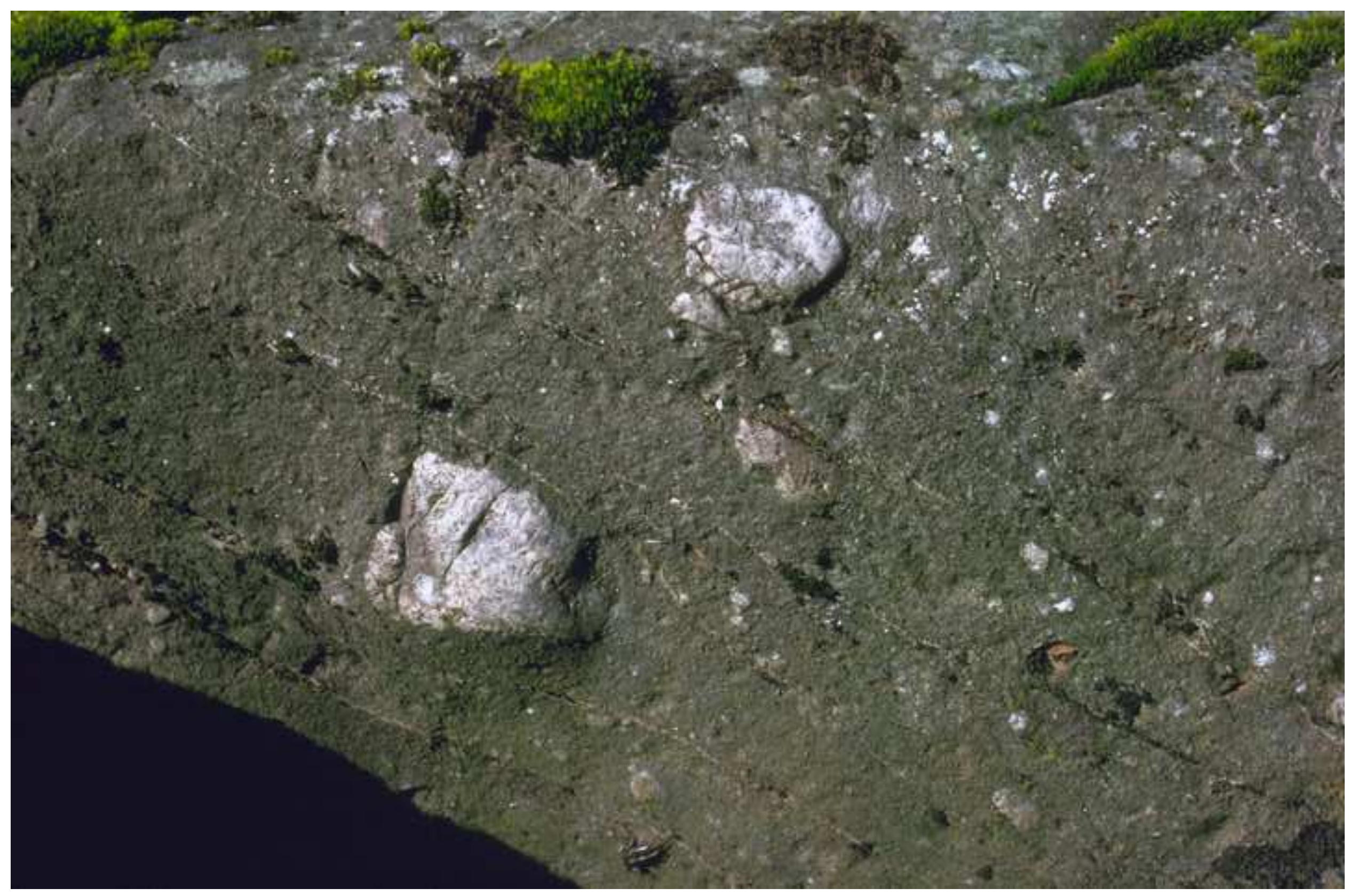


Figure 6.19 colour
Click here to download high resolution image

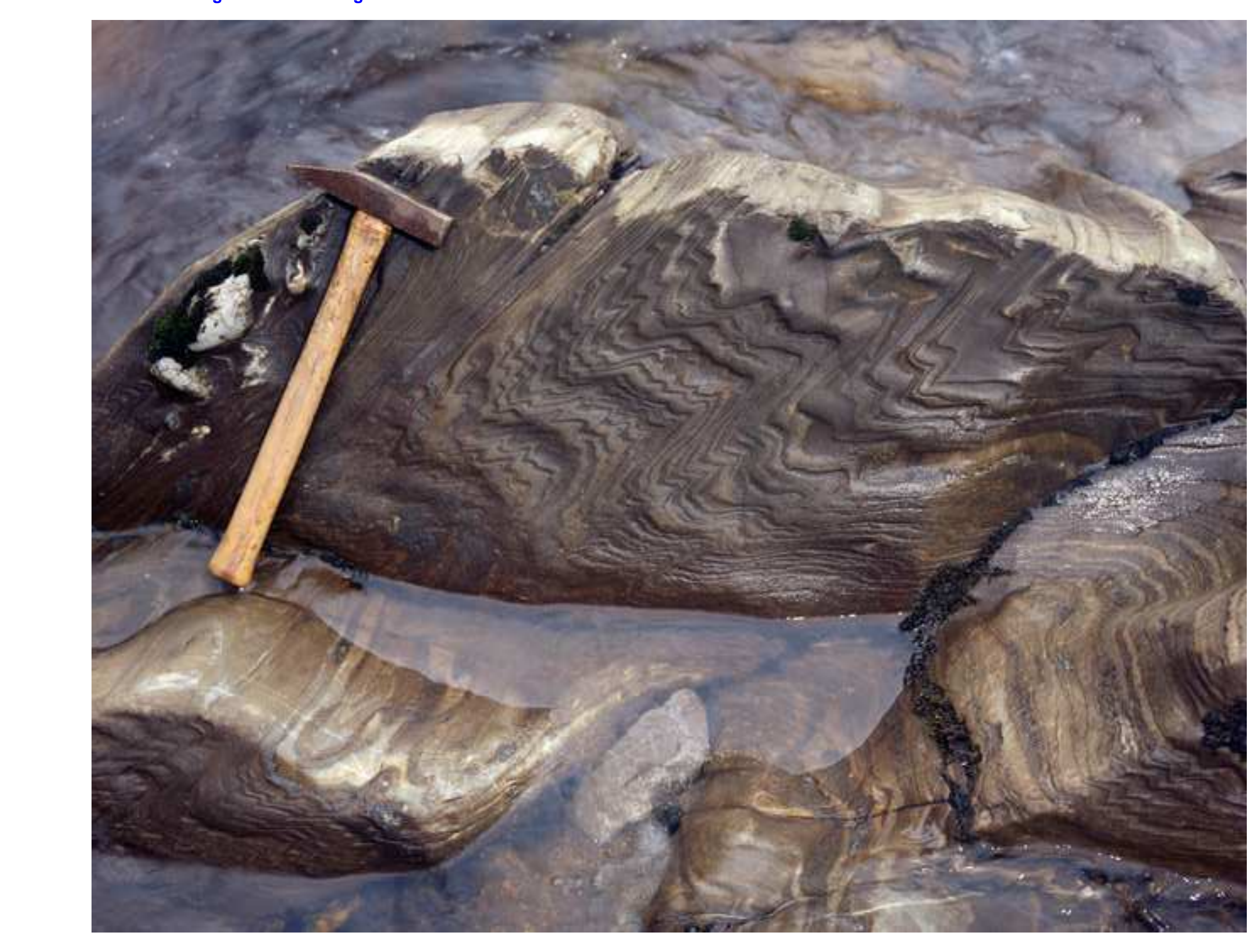

Click here to download high resolution imag
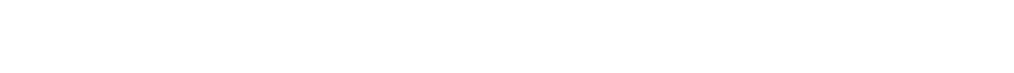


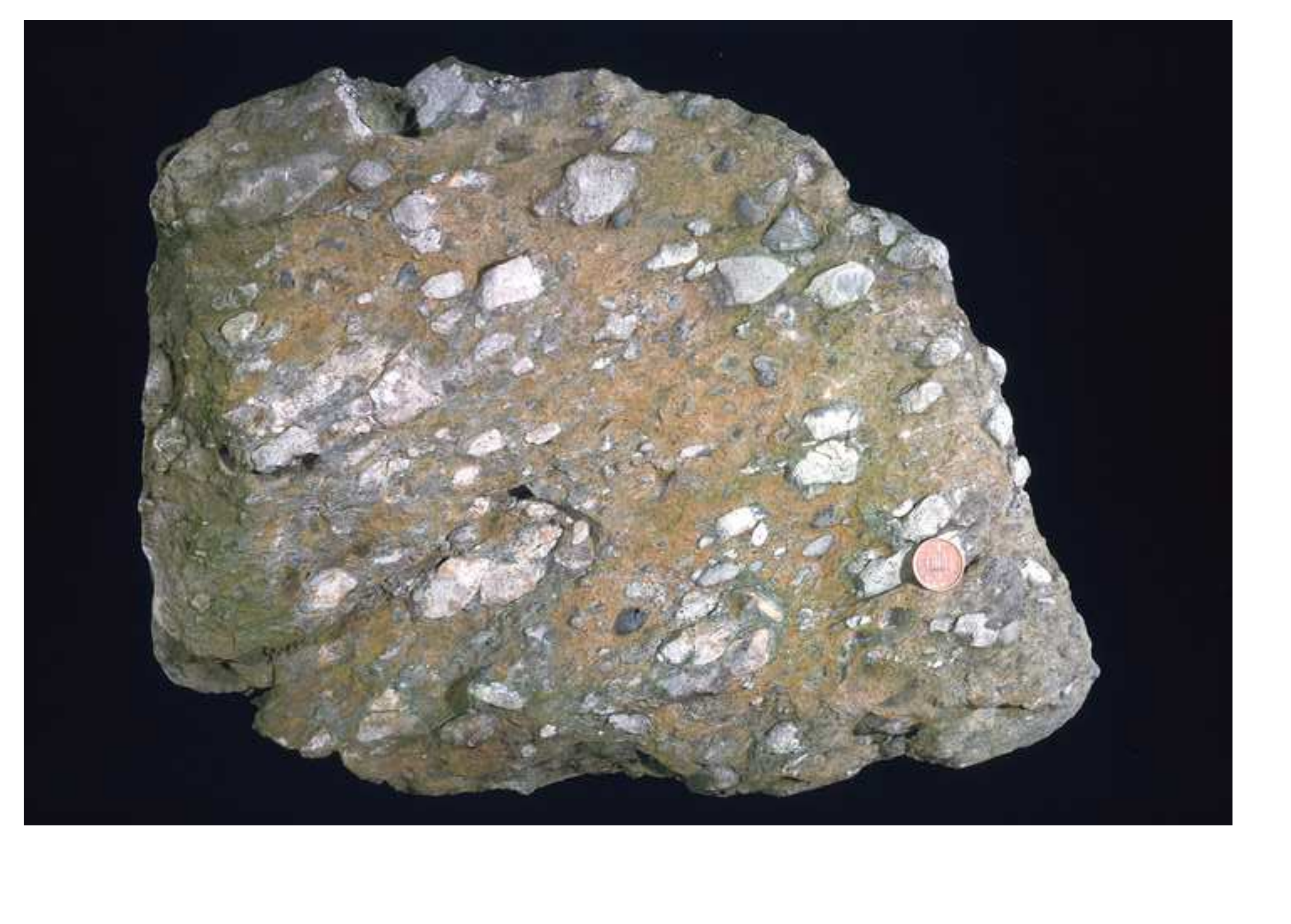

\section{Clck here to download high resolution image}
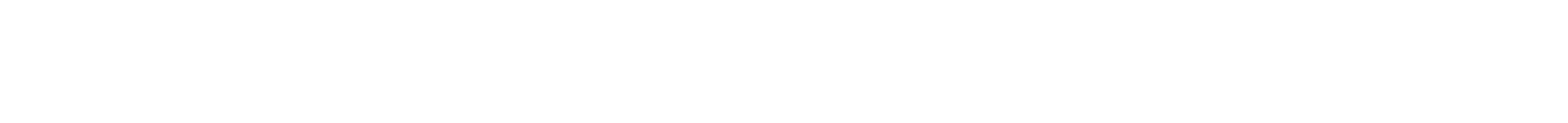


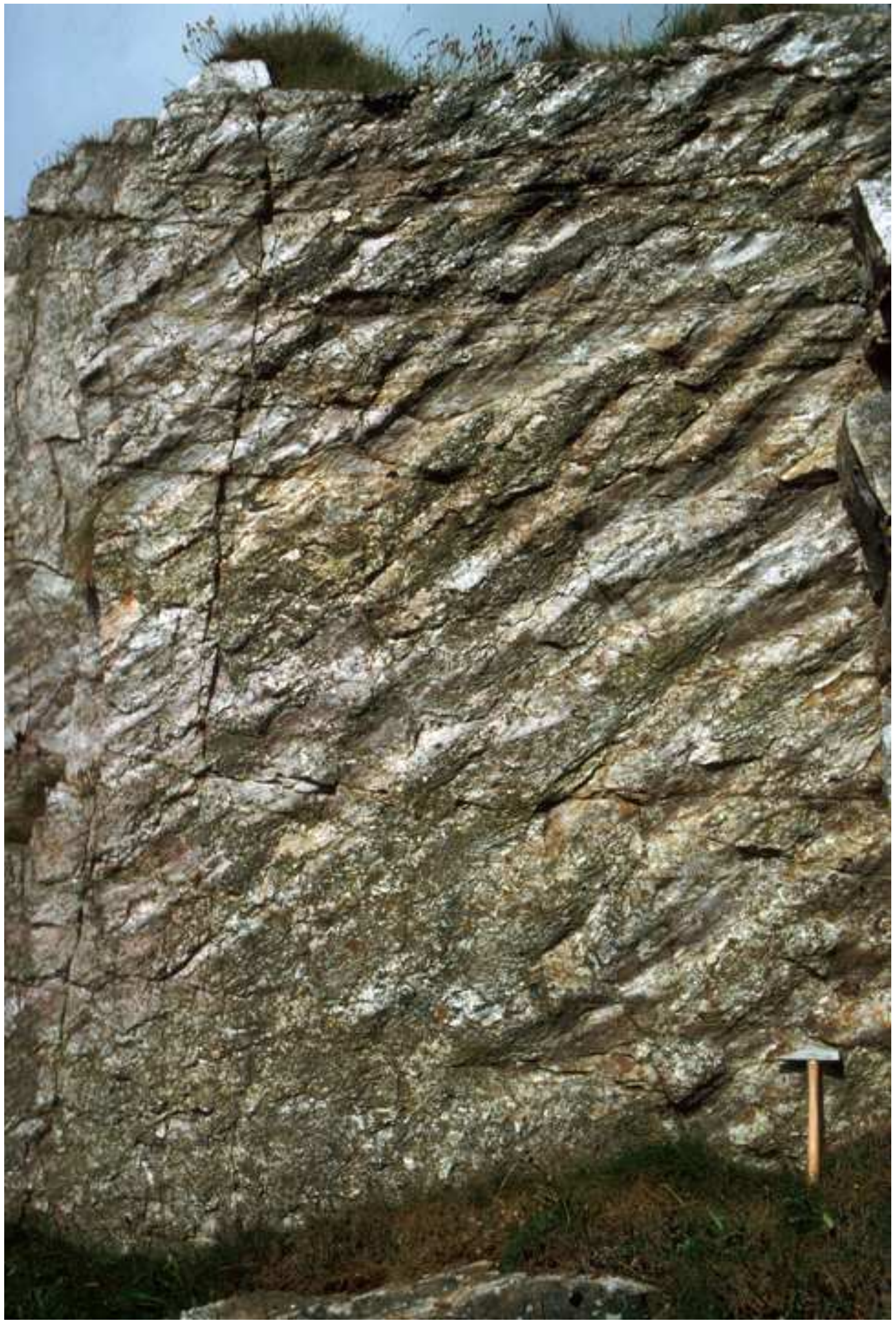


Click here to download high resolution image

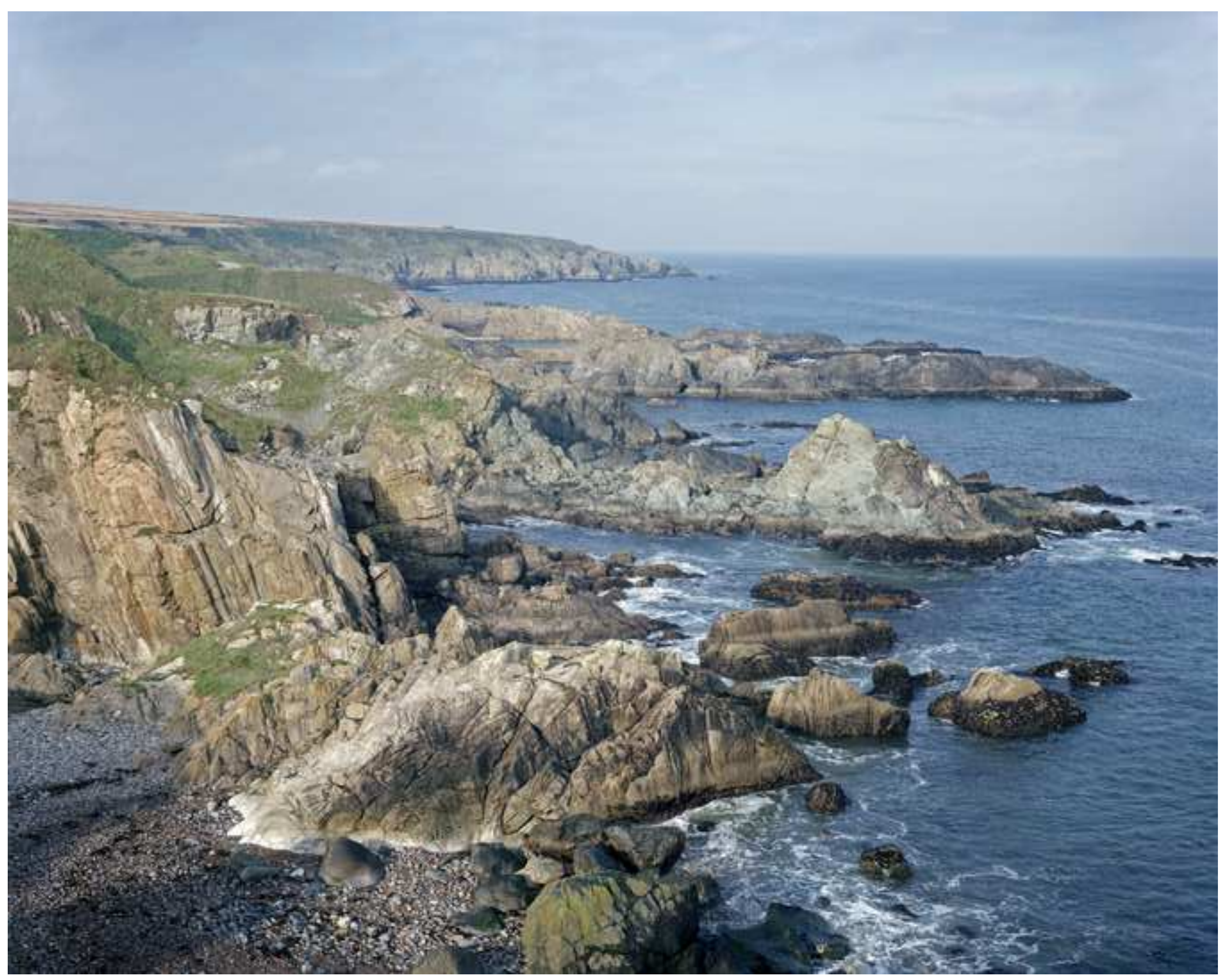


Click here to download high resolution image

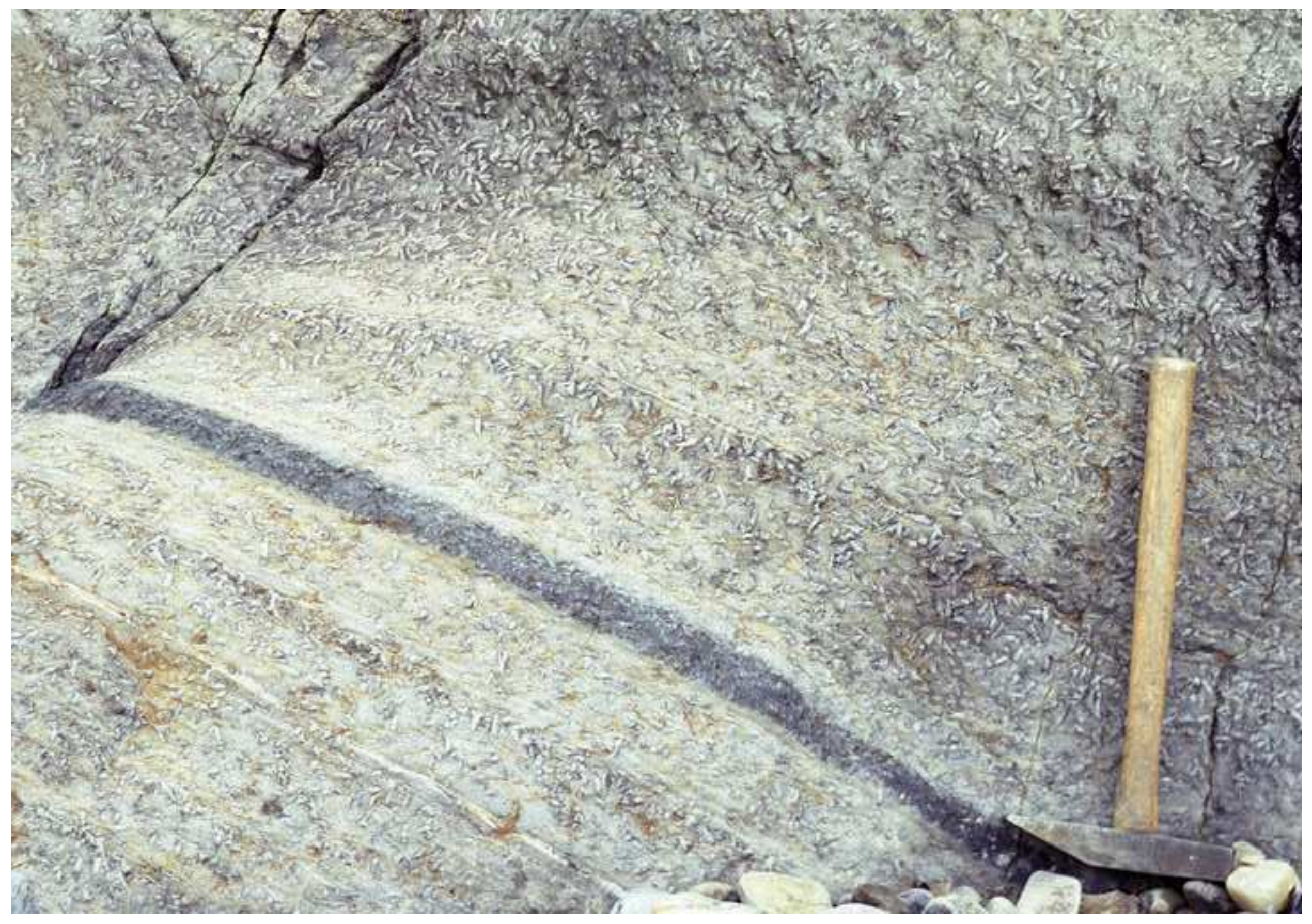


Click here to download high resolution image

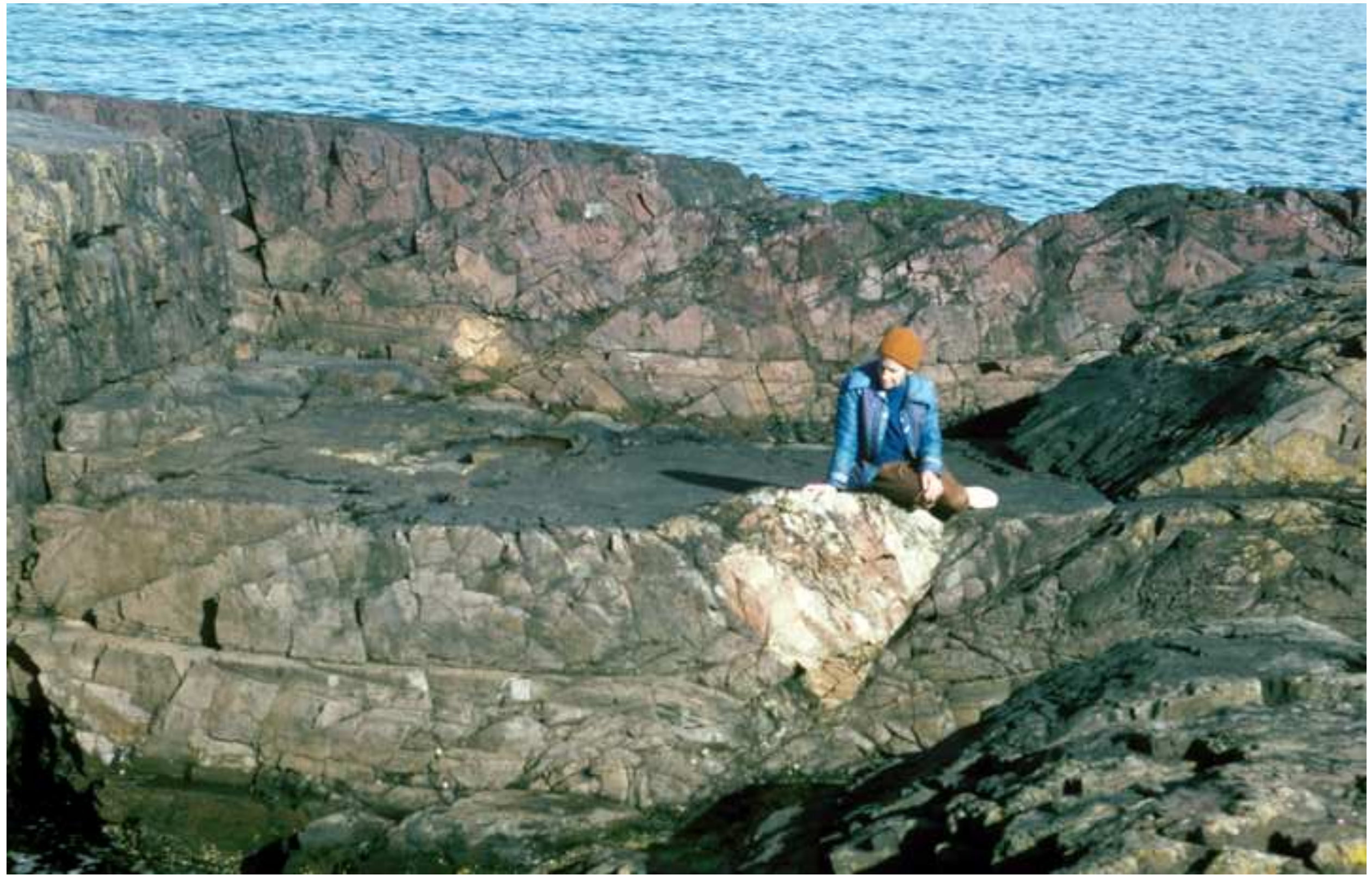


Click here to download high resolution image

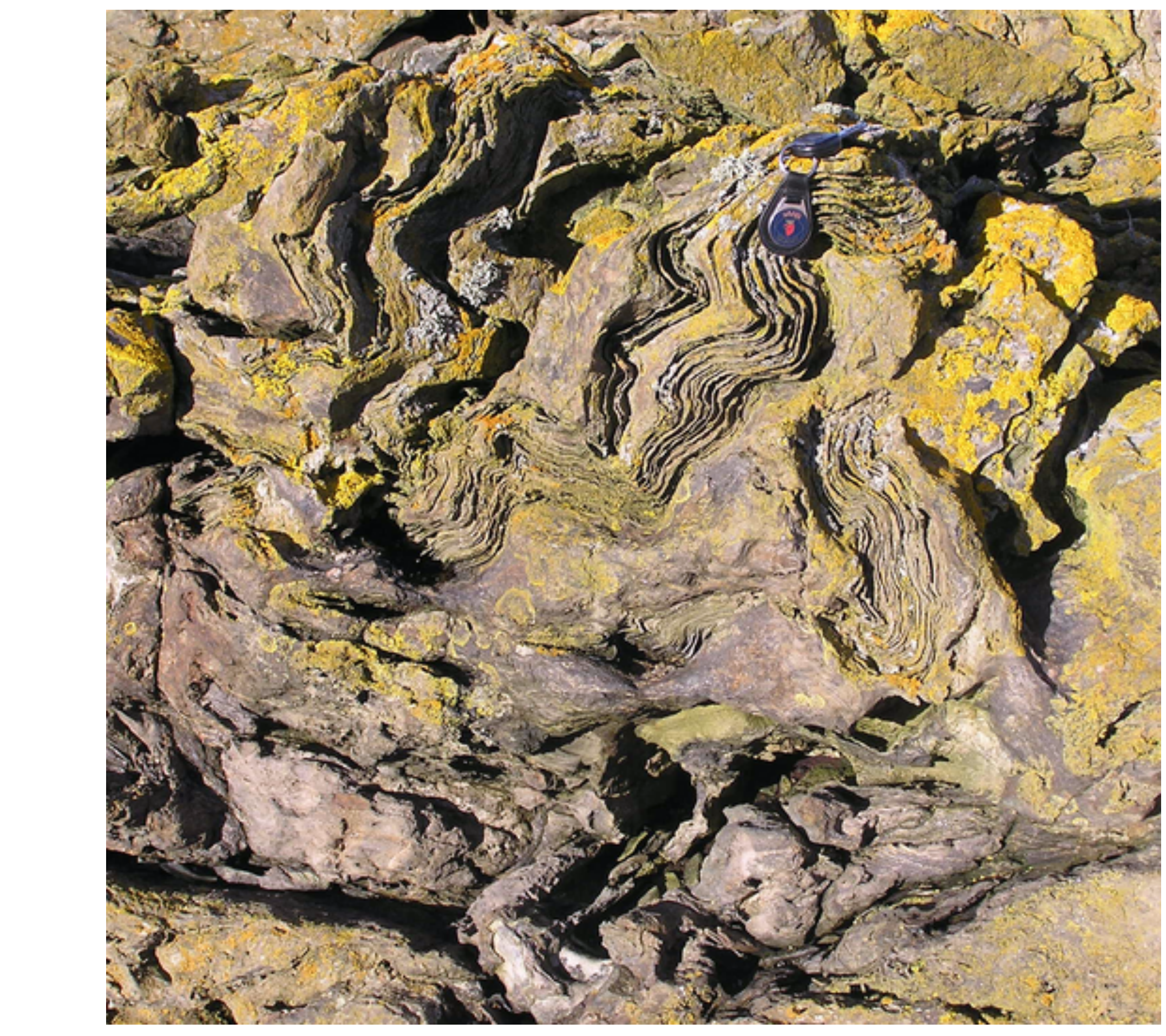




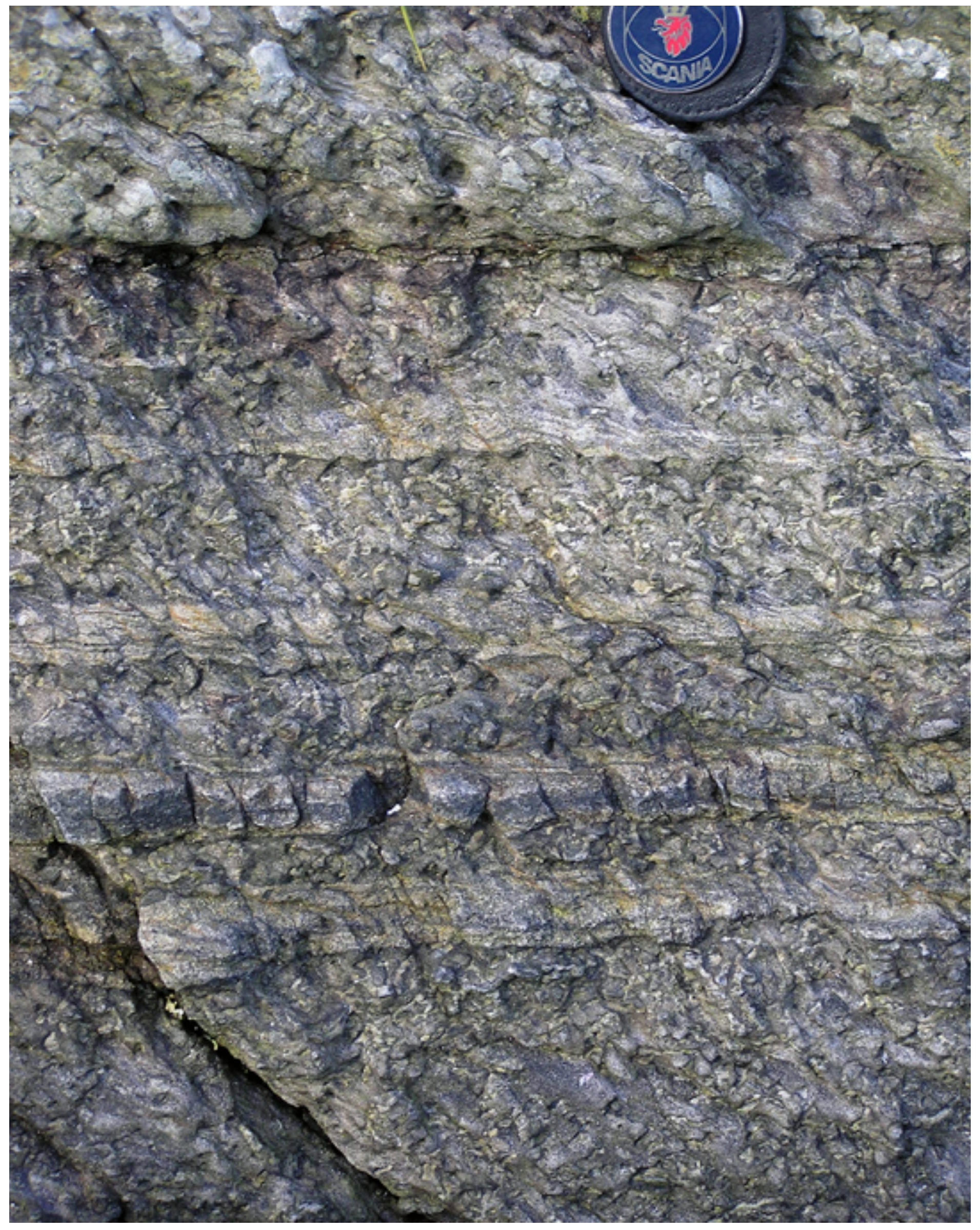


Figure 6.34 colour
Click here to download high resolution image

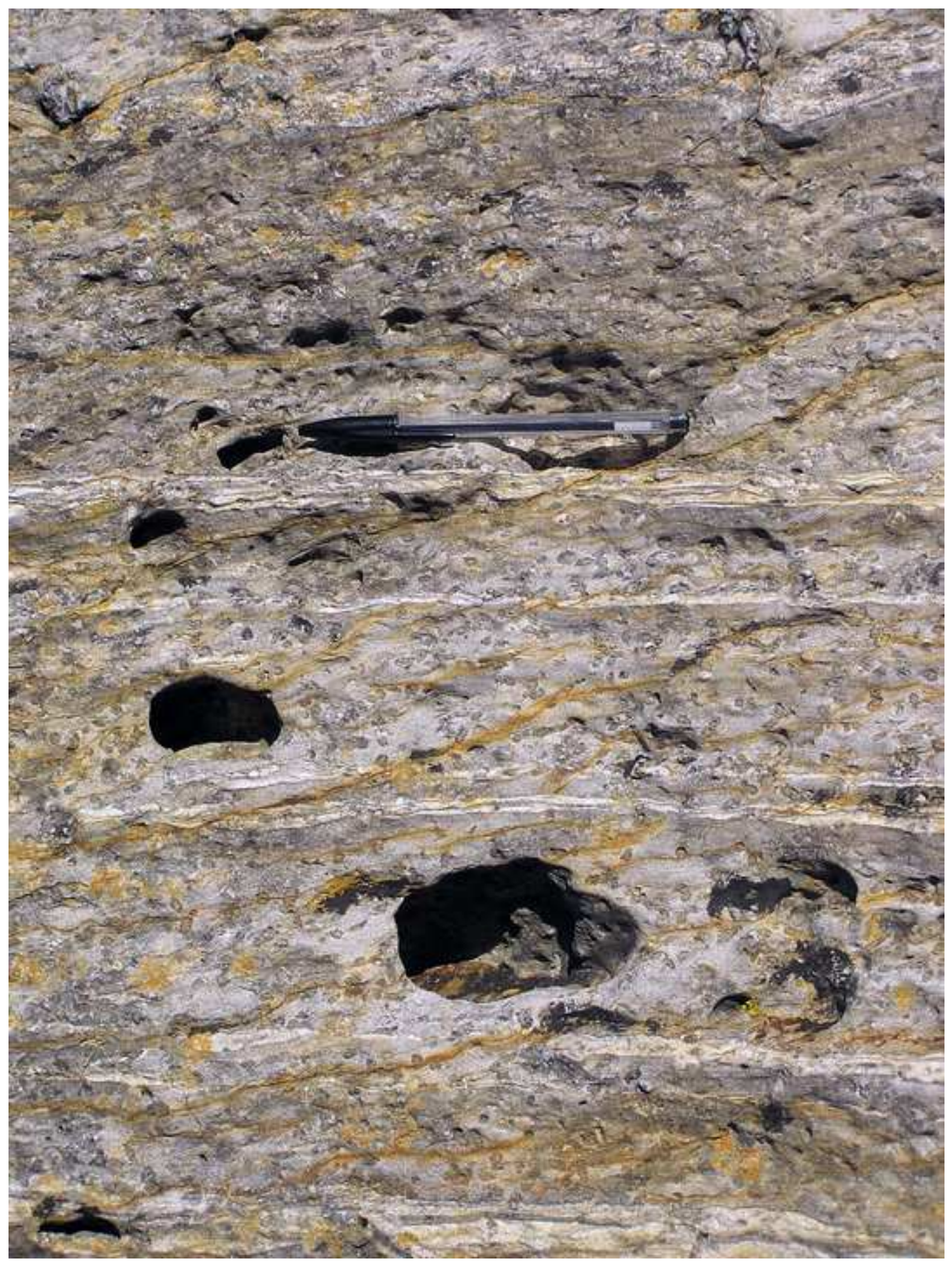


Figure 6.37 colour

Click here to download high resolution image

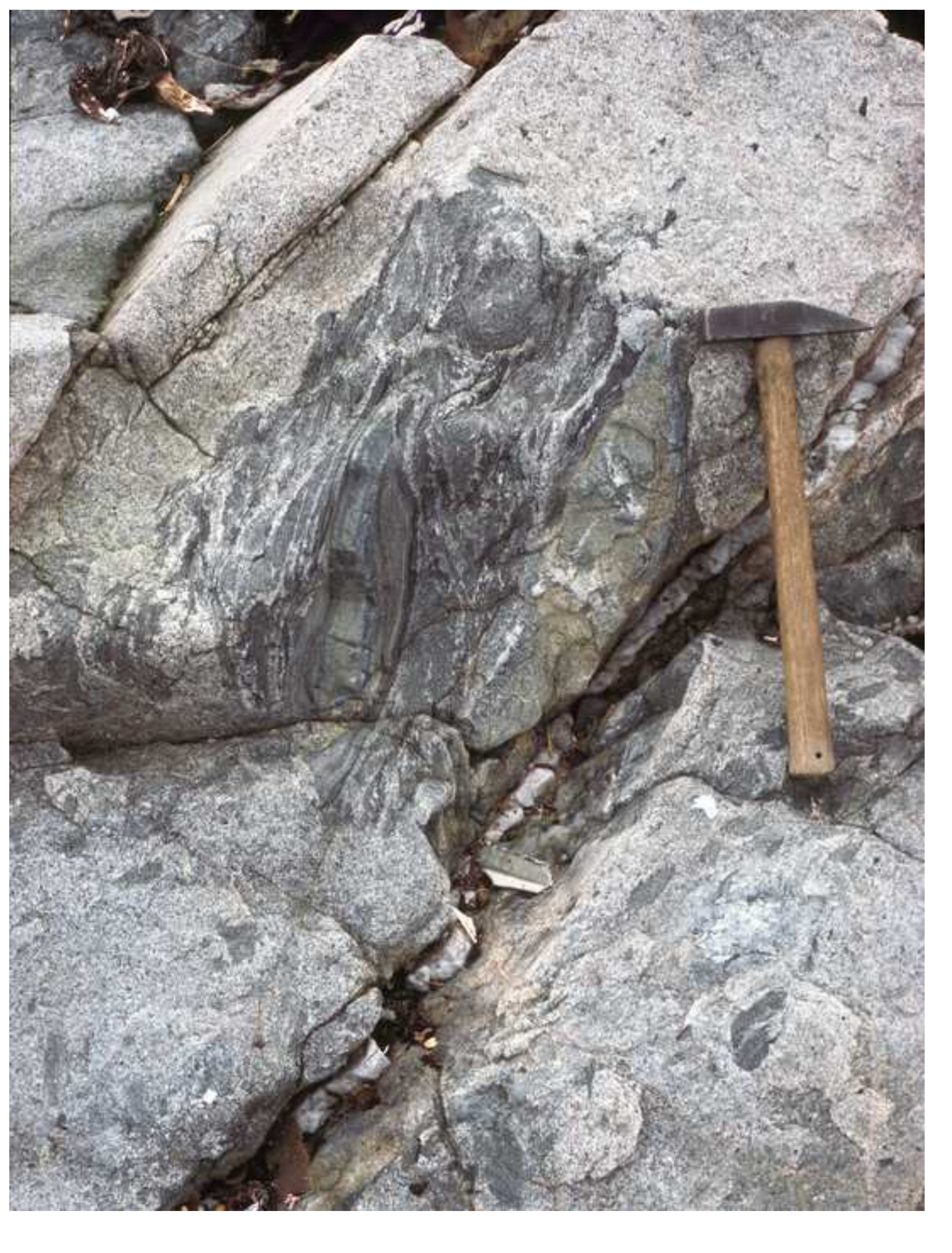


Click here to download high resolution image

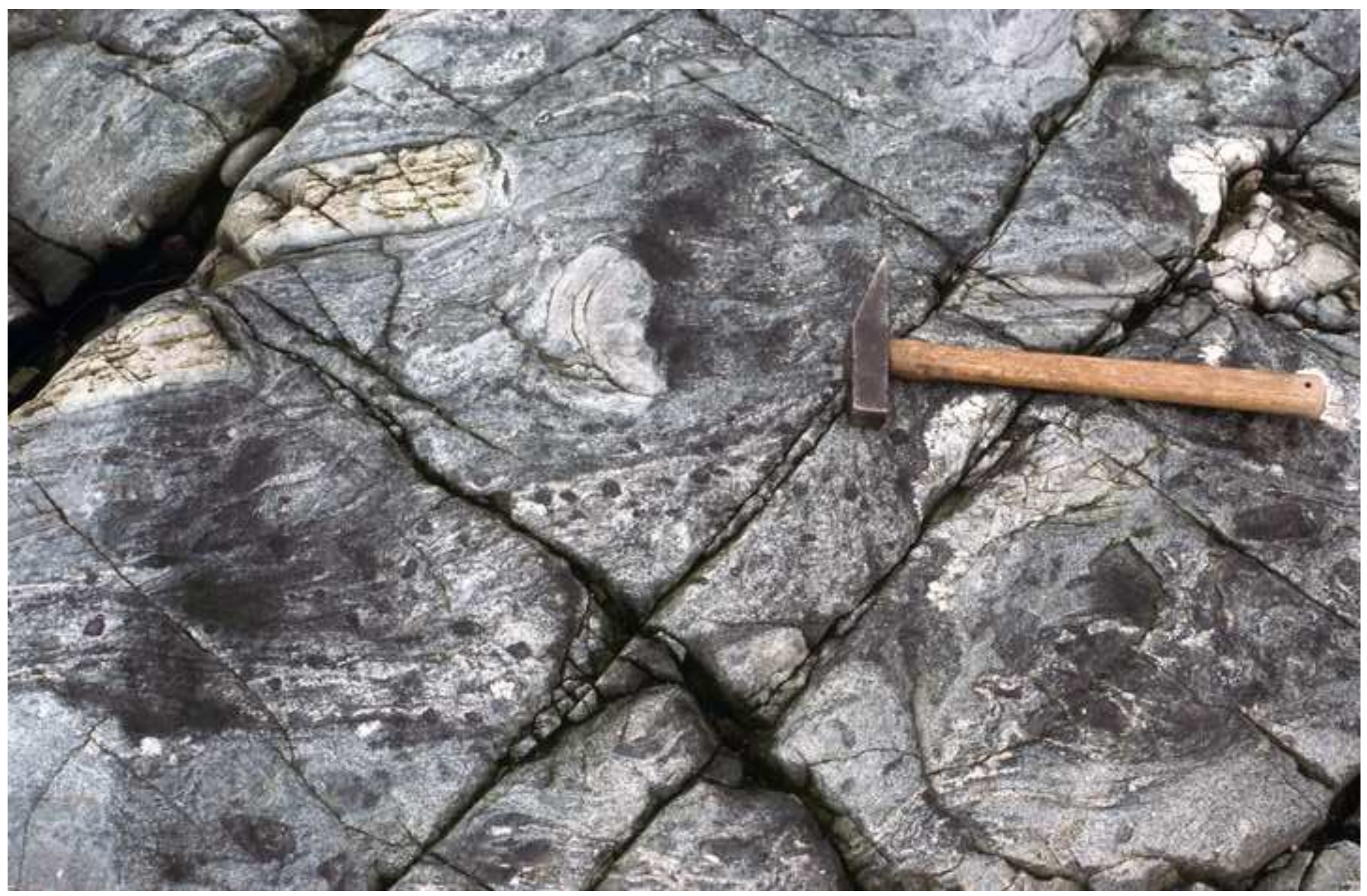


Figure 6.41 colour
Click here to download high resolution image

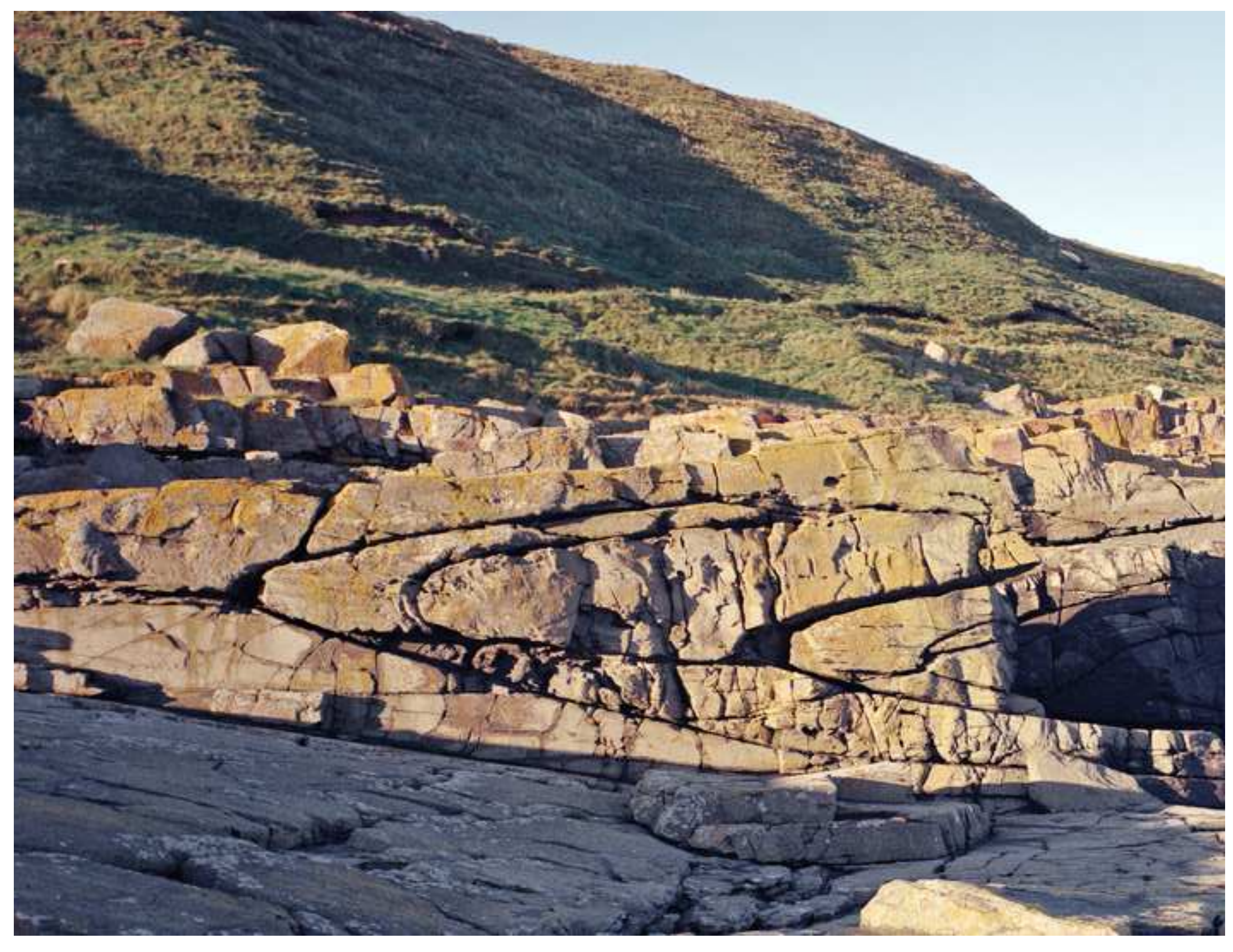


Figure 6.2

Click here to download high resolution image

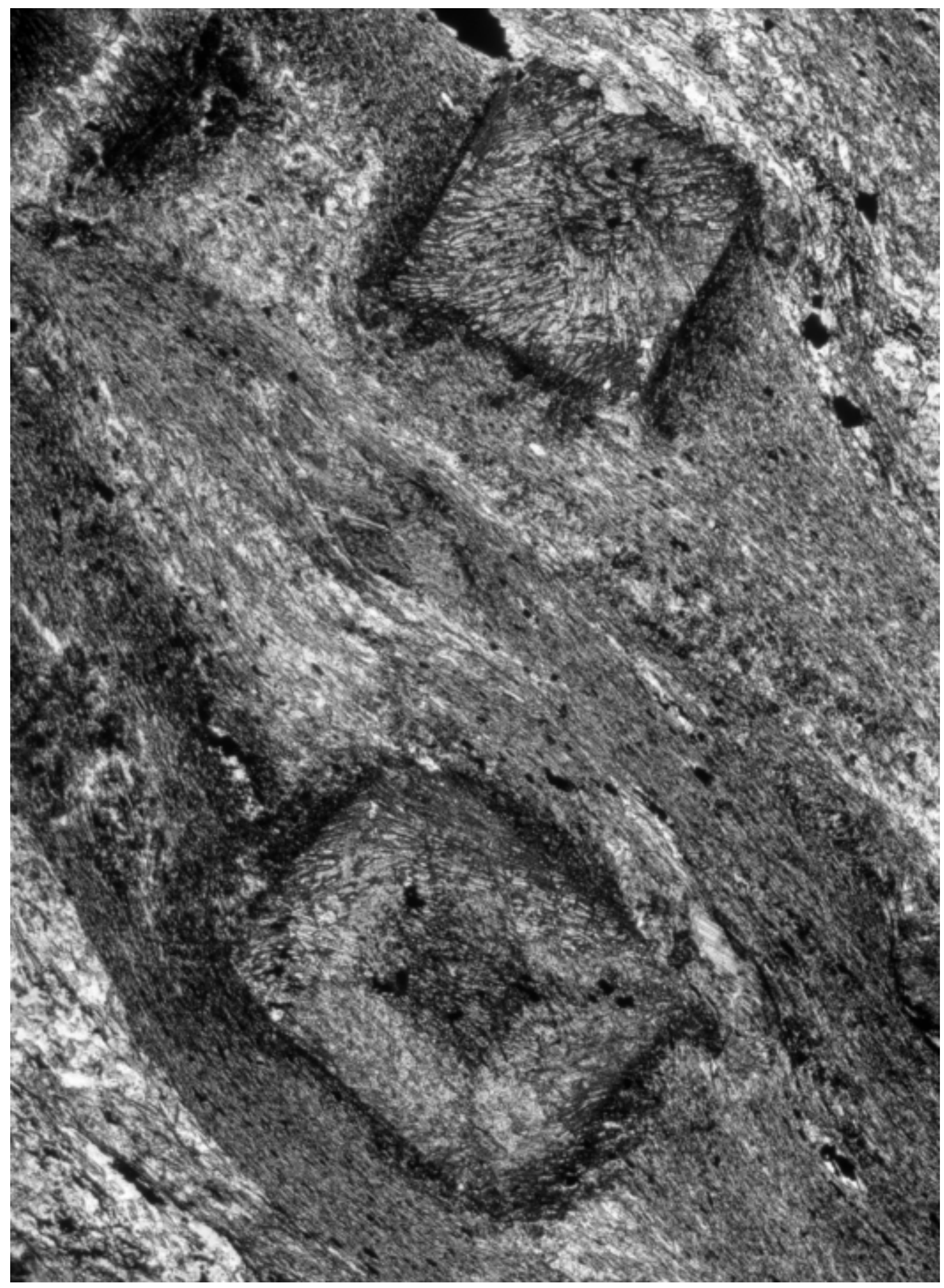




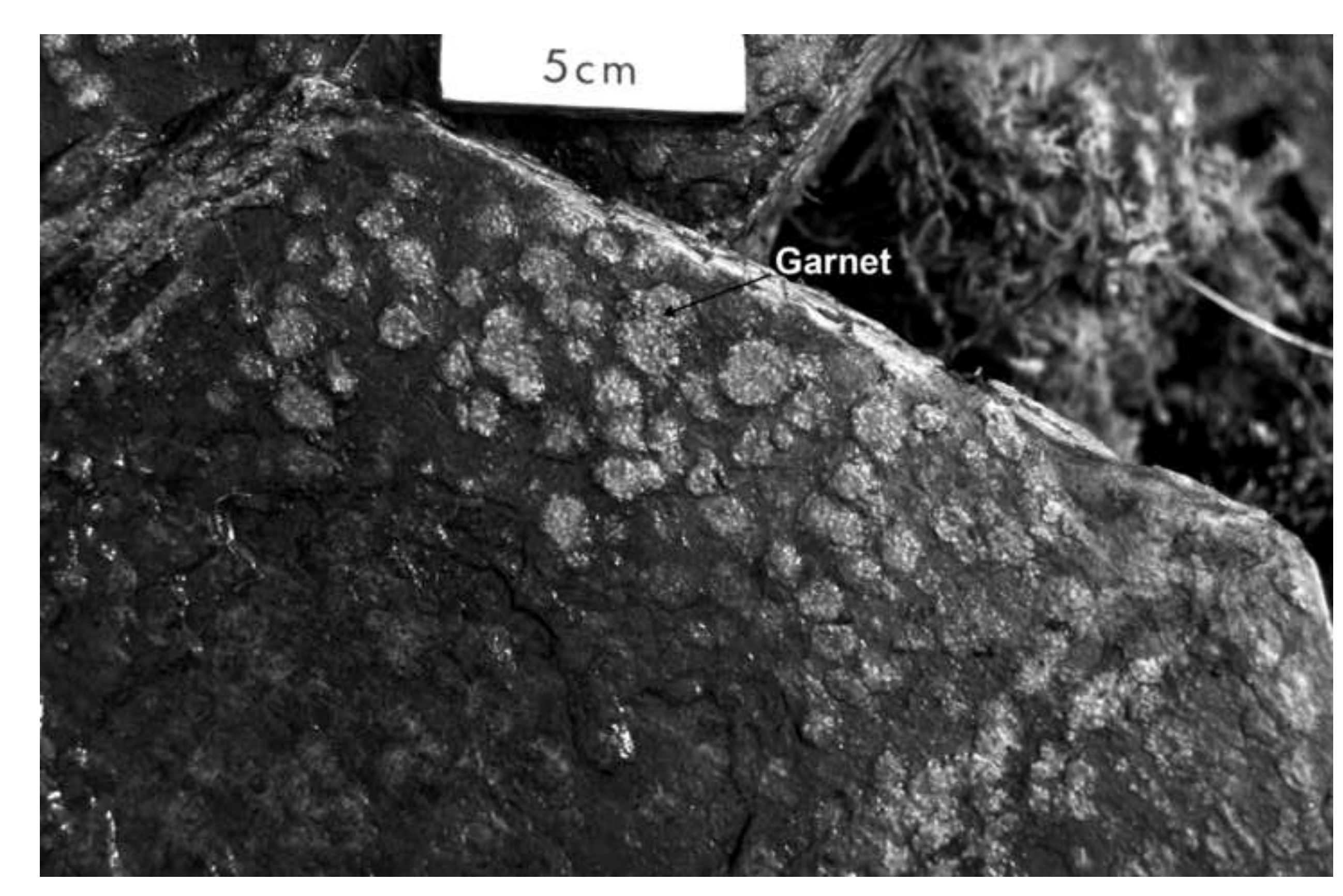


Click here to download high resolution image

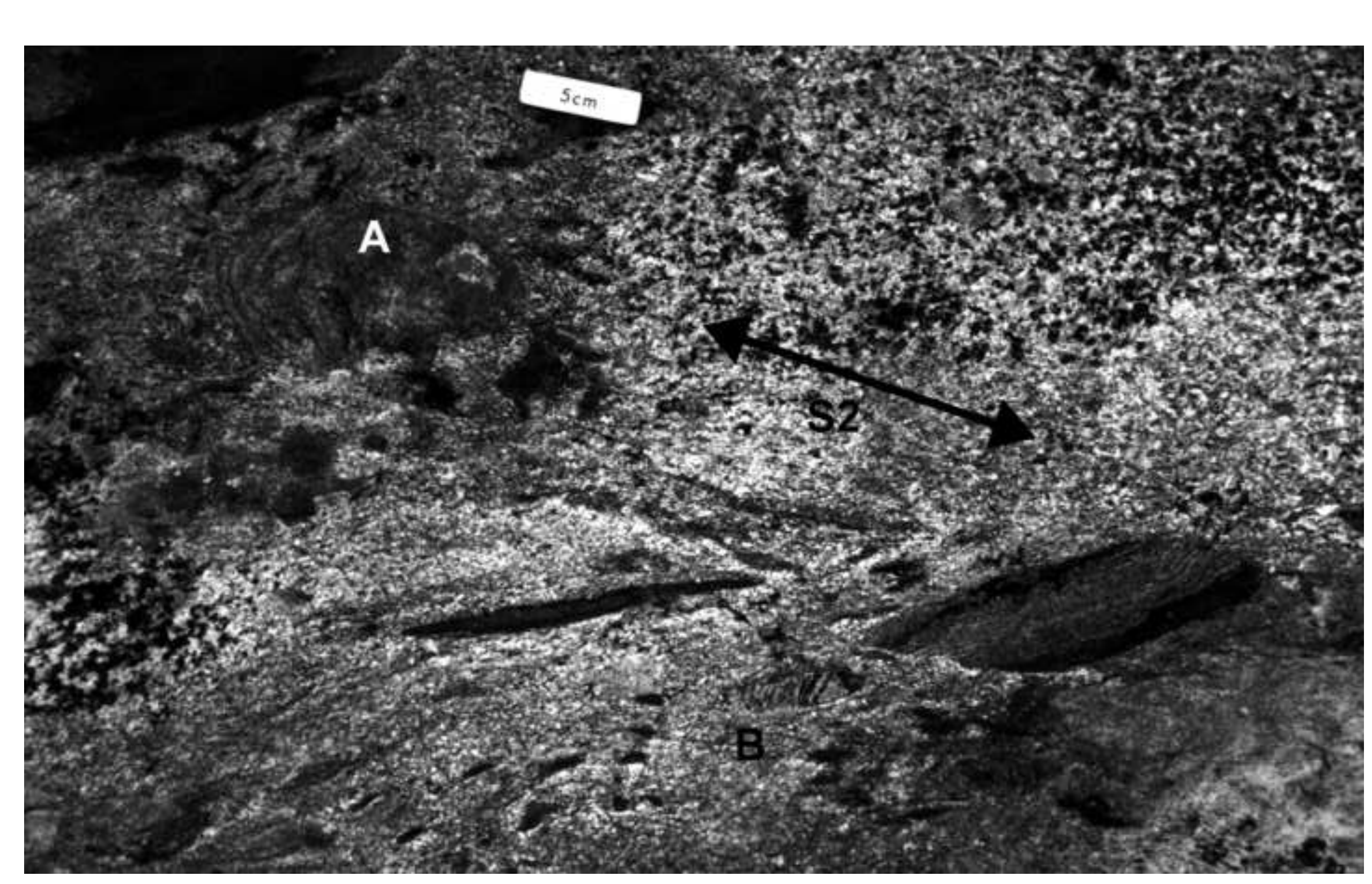


F.12 B\&W

Click here to download high resolution image

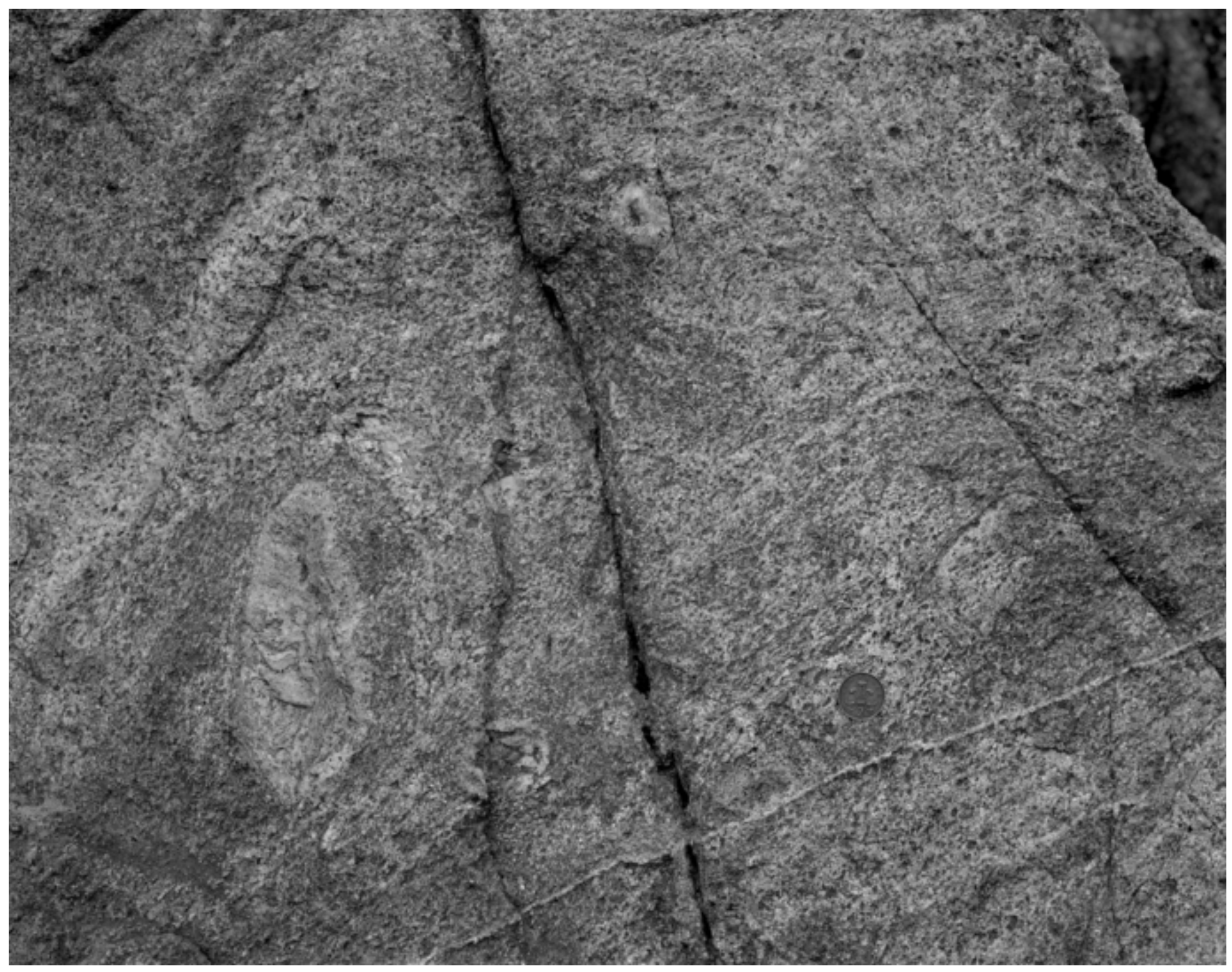


Figure $6.13 \mathrm{~B} \& W$
Click here to download high resolution image

Figure $6.13 \mathrm{~B} \& W$
Click here to download high resolution image

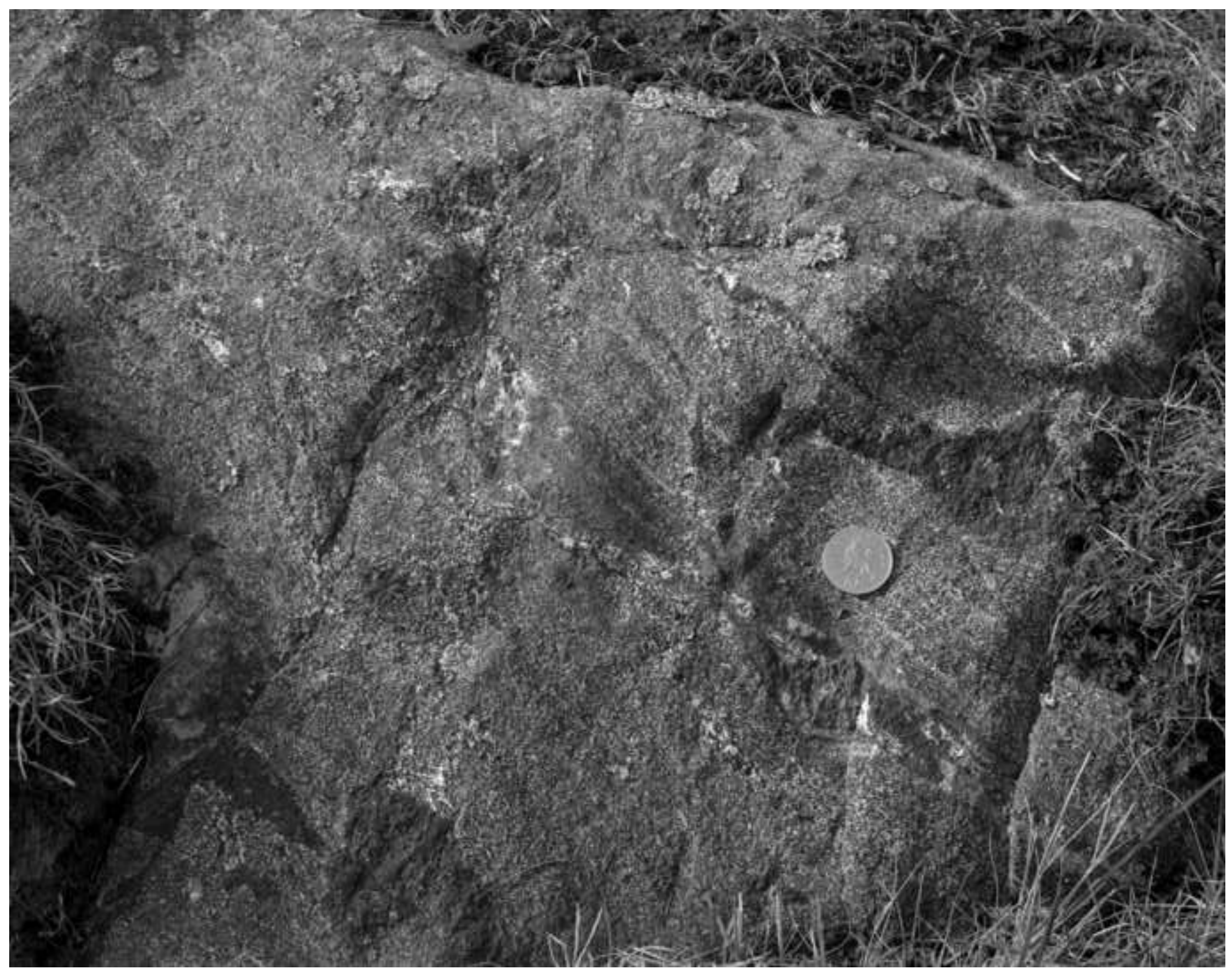




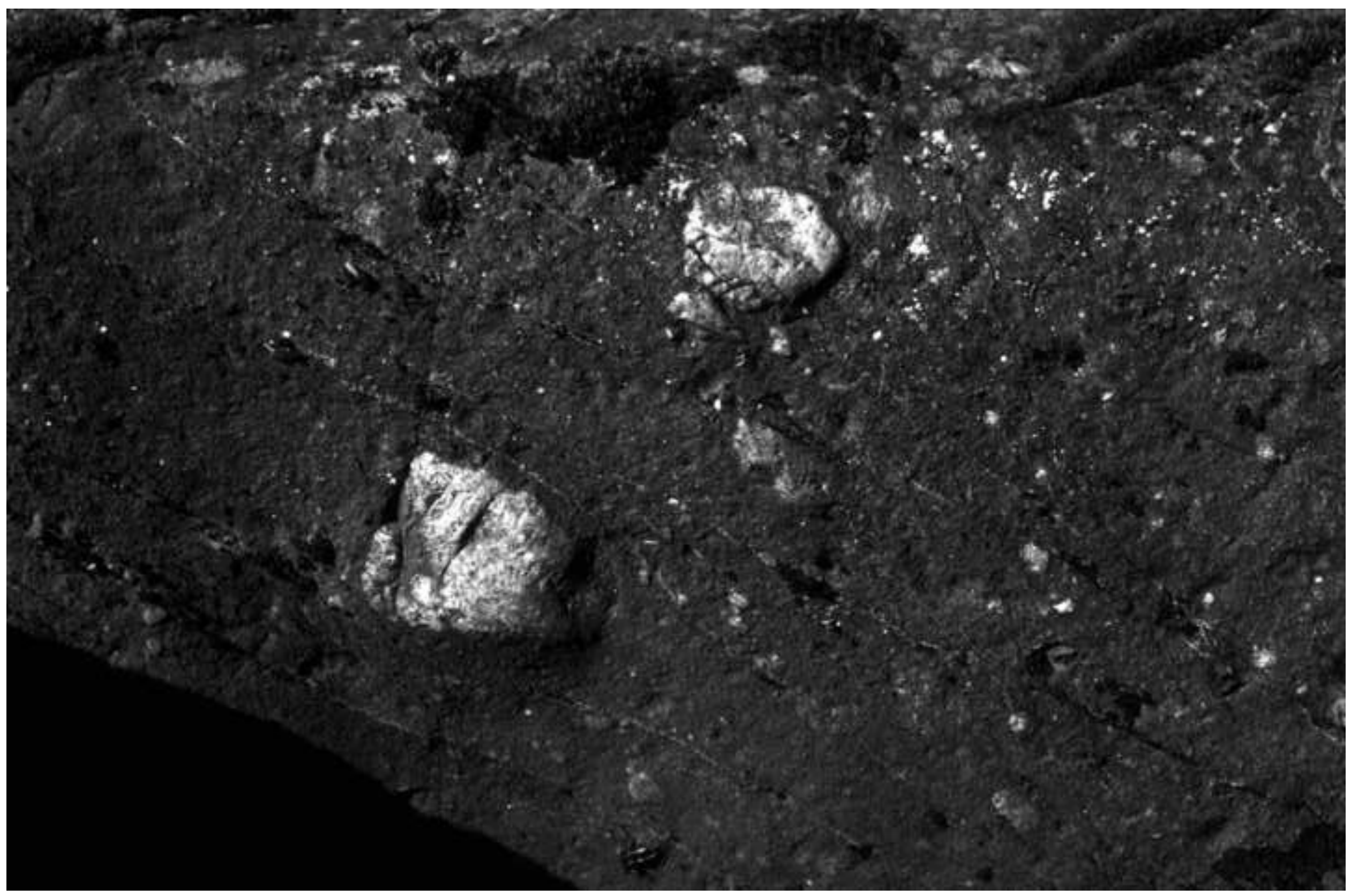


Click here to download high resolution image

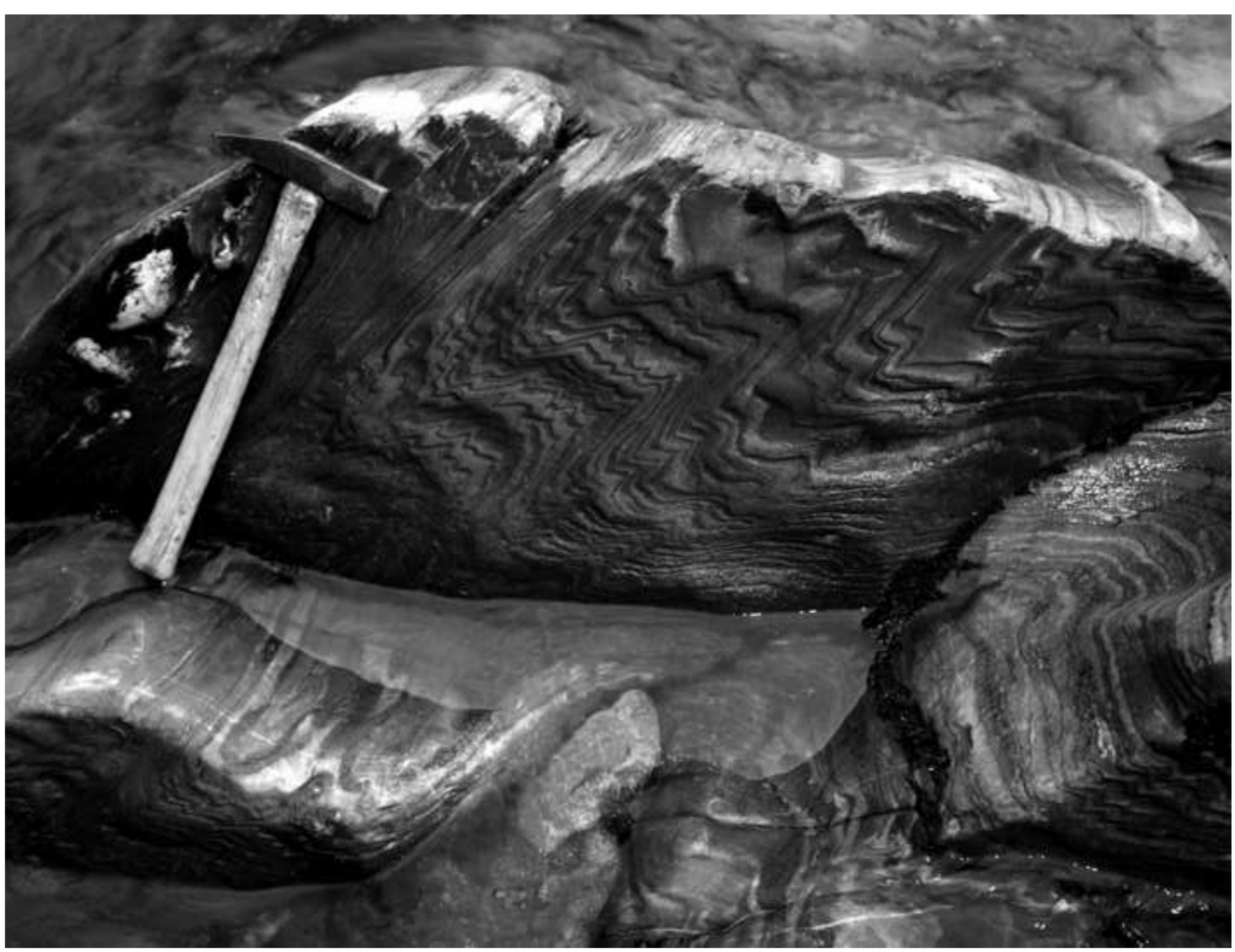




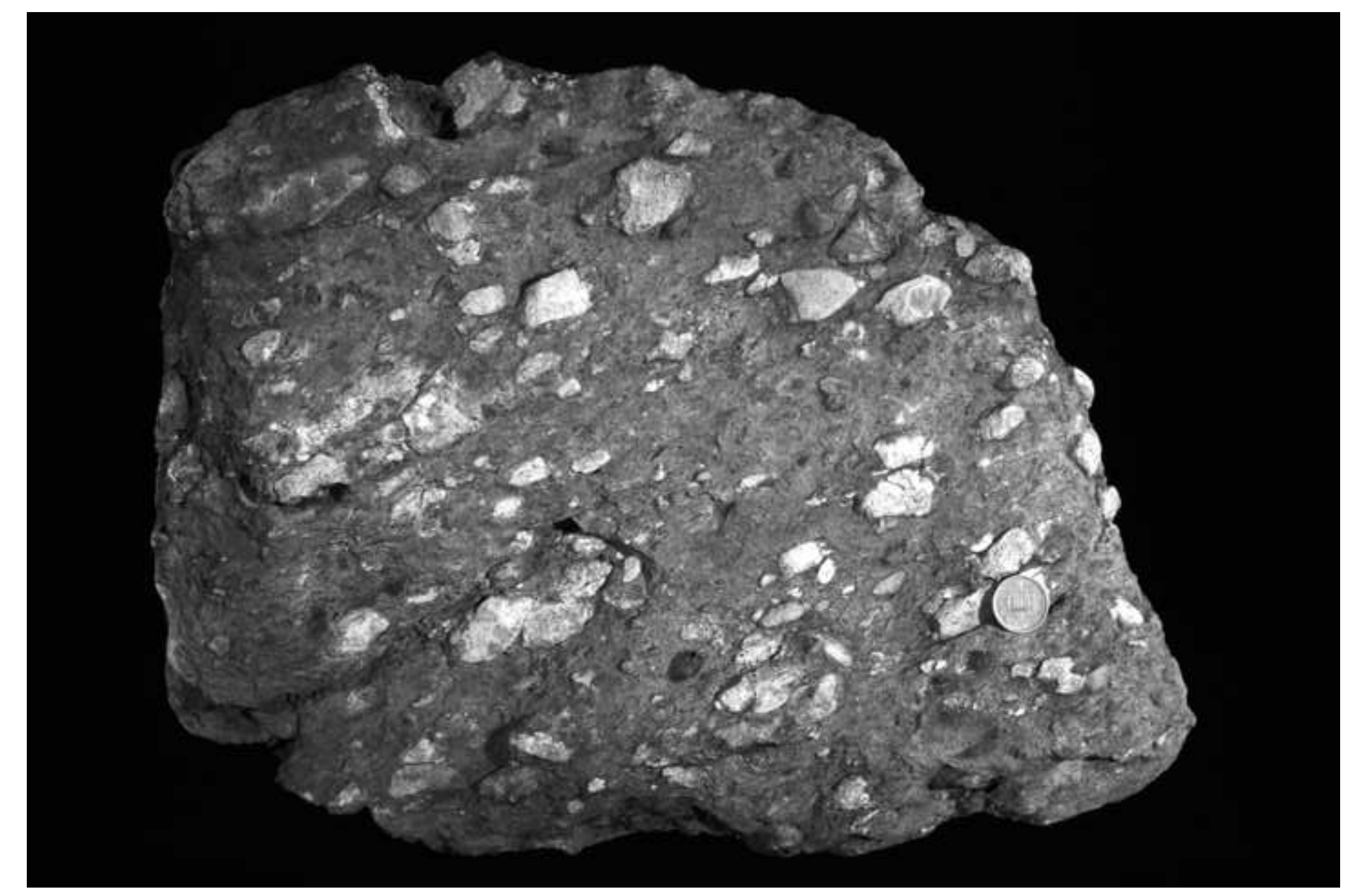




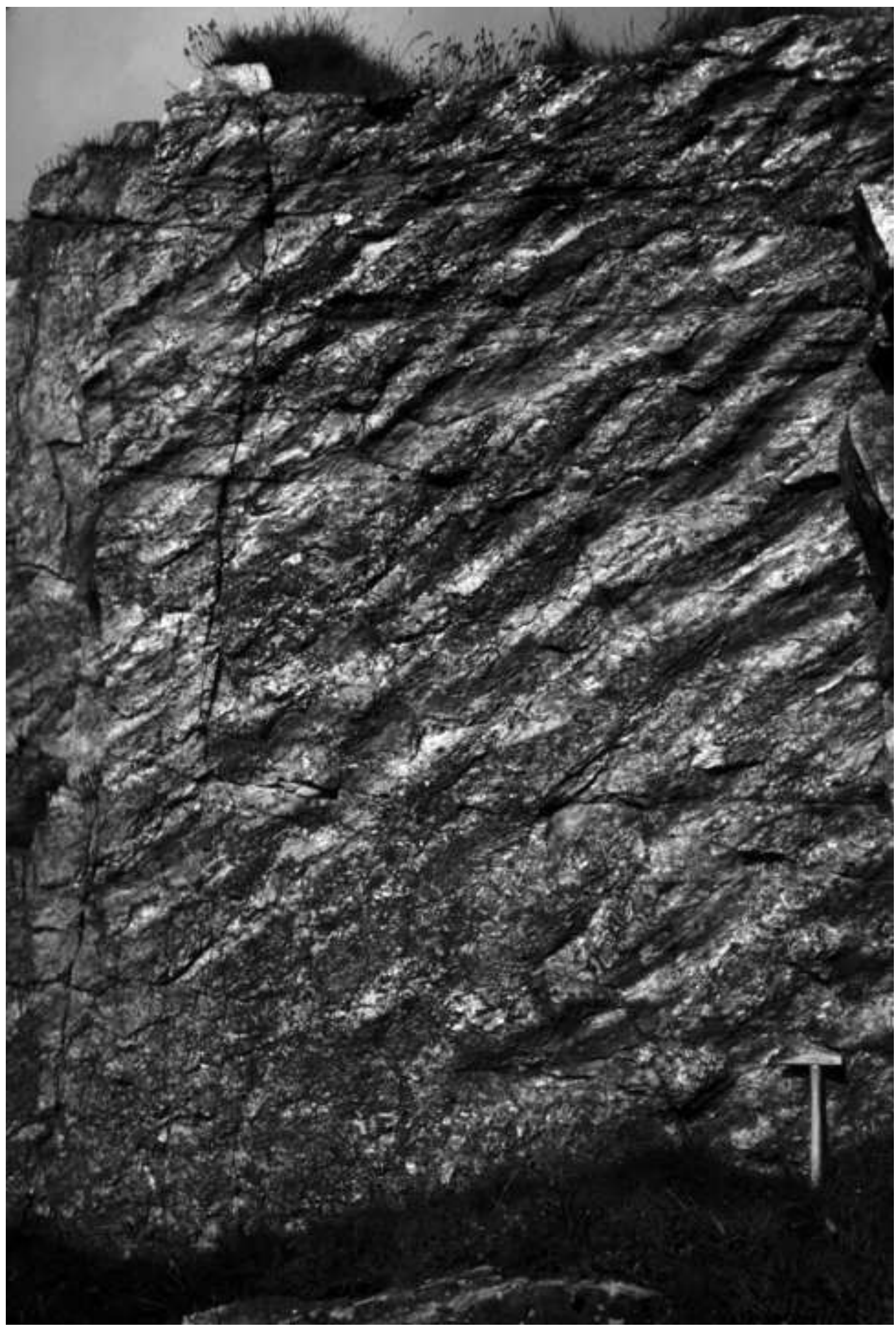


Click here to download high resolution image

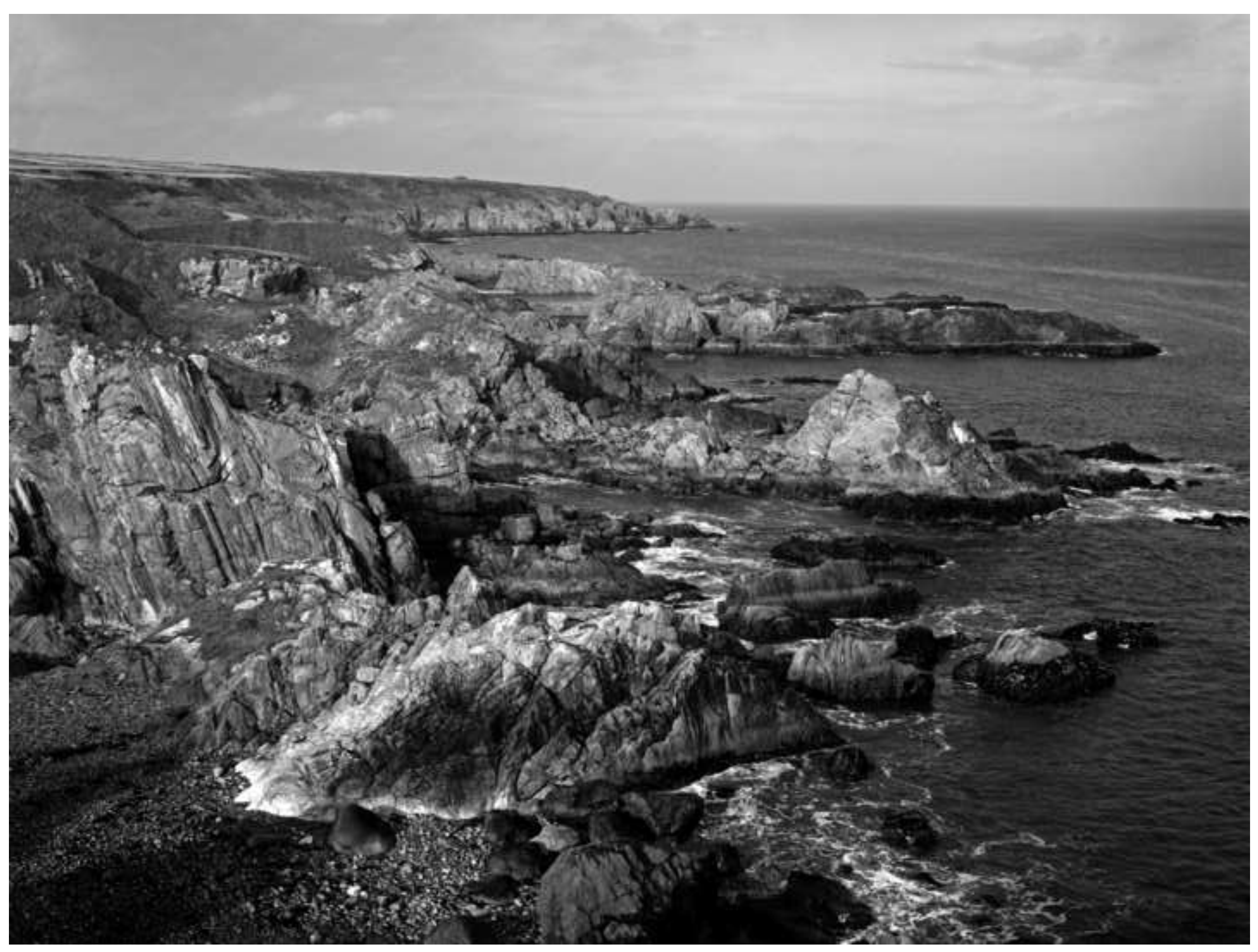

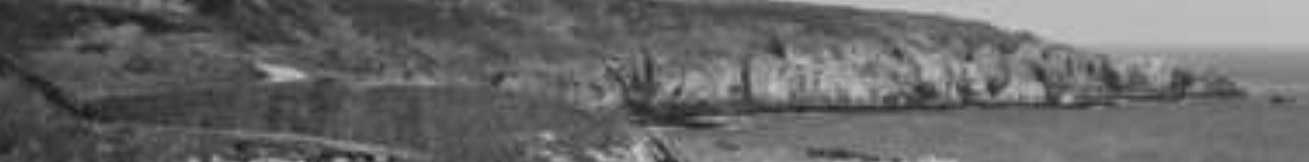


Click here to download high resolution image

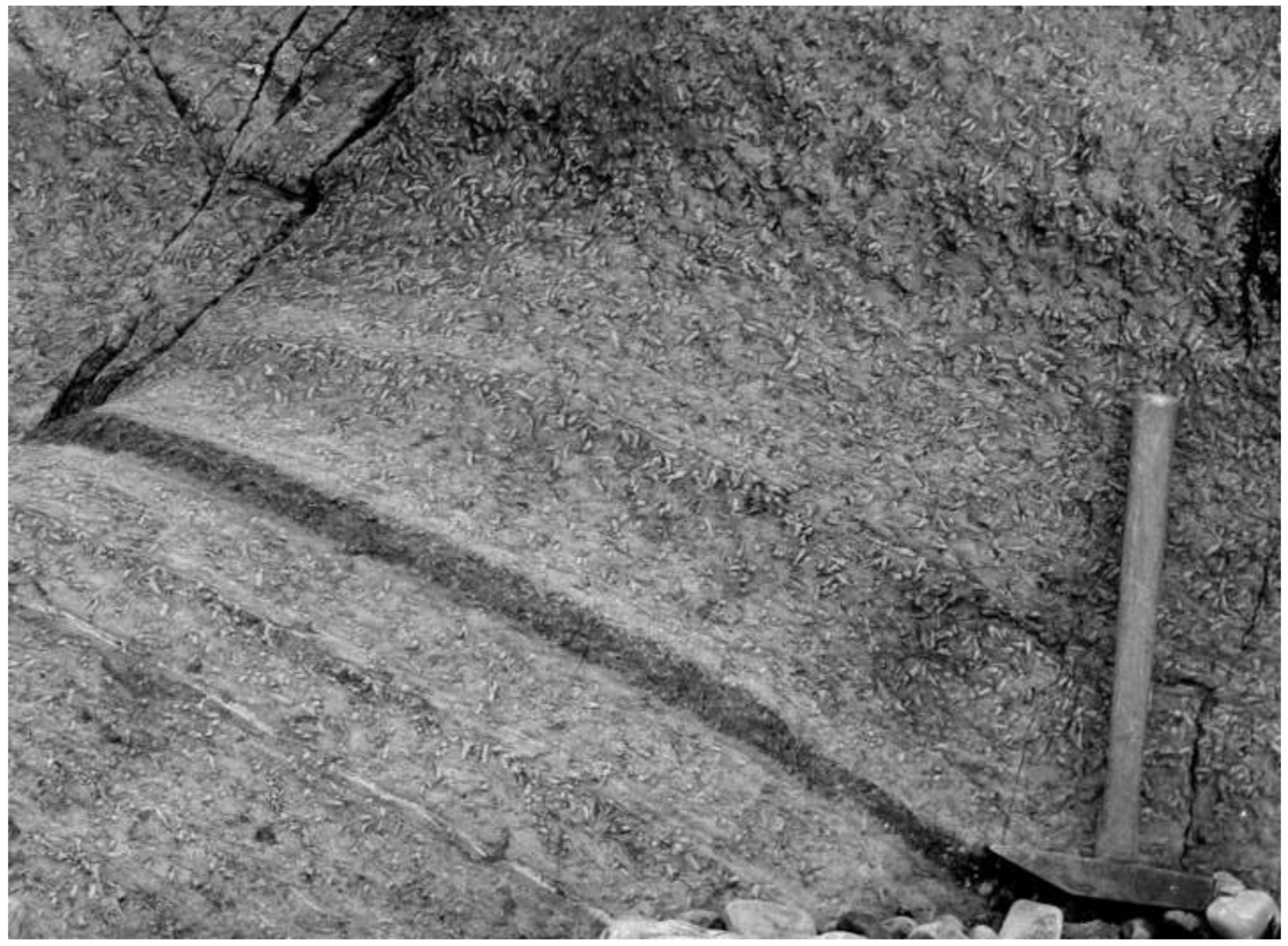




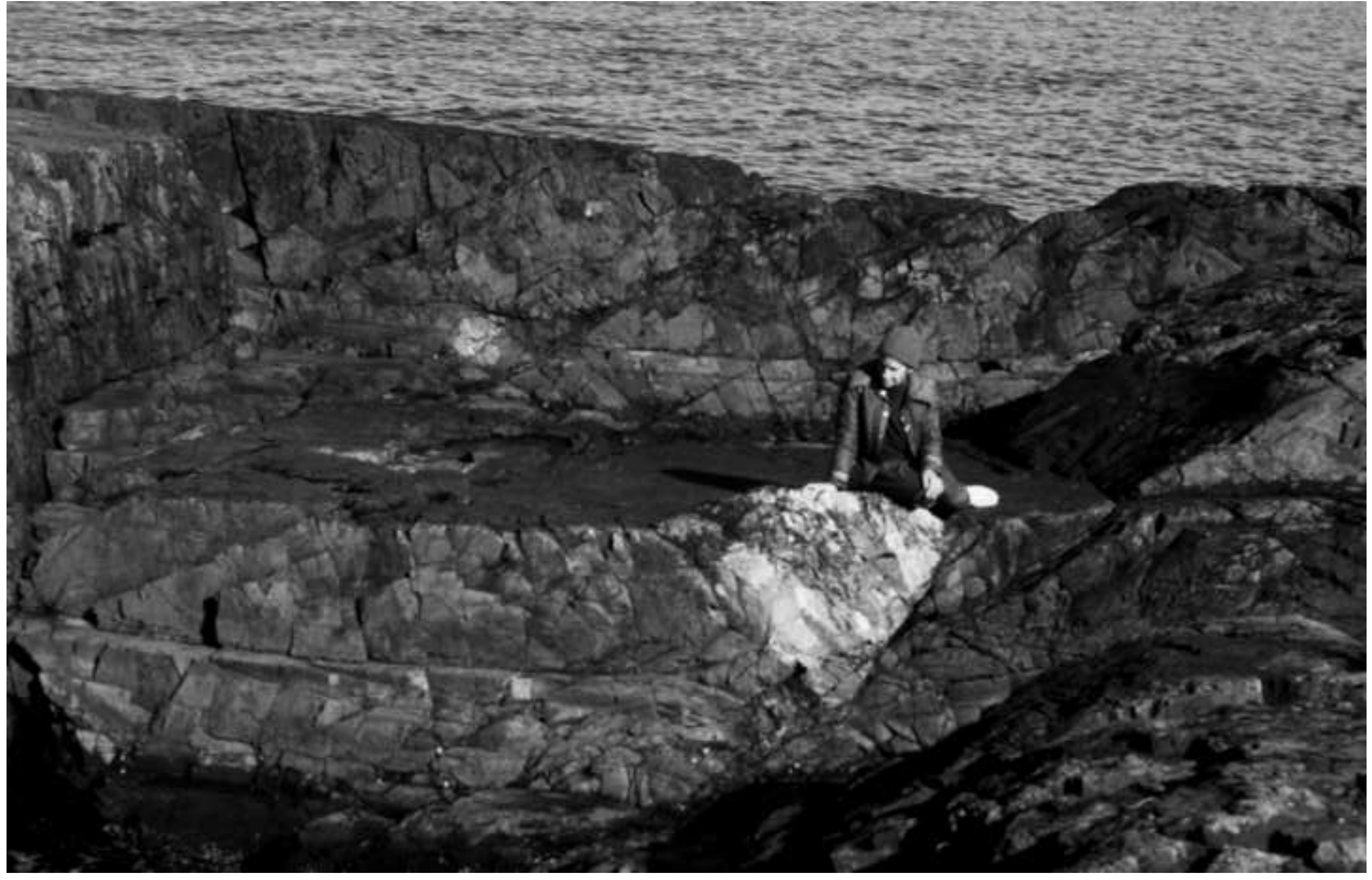


Click here to download high resolution image

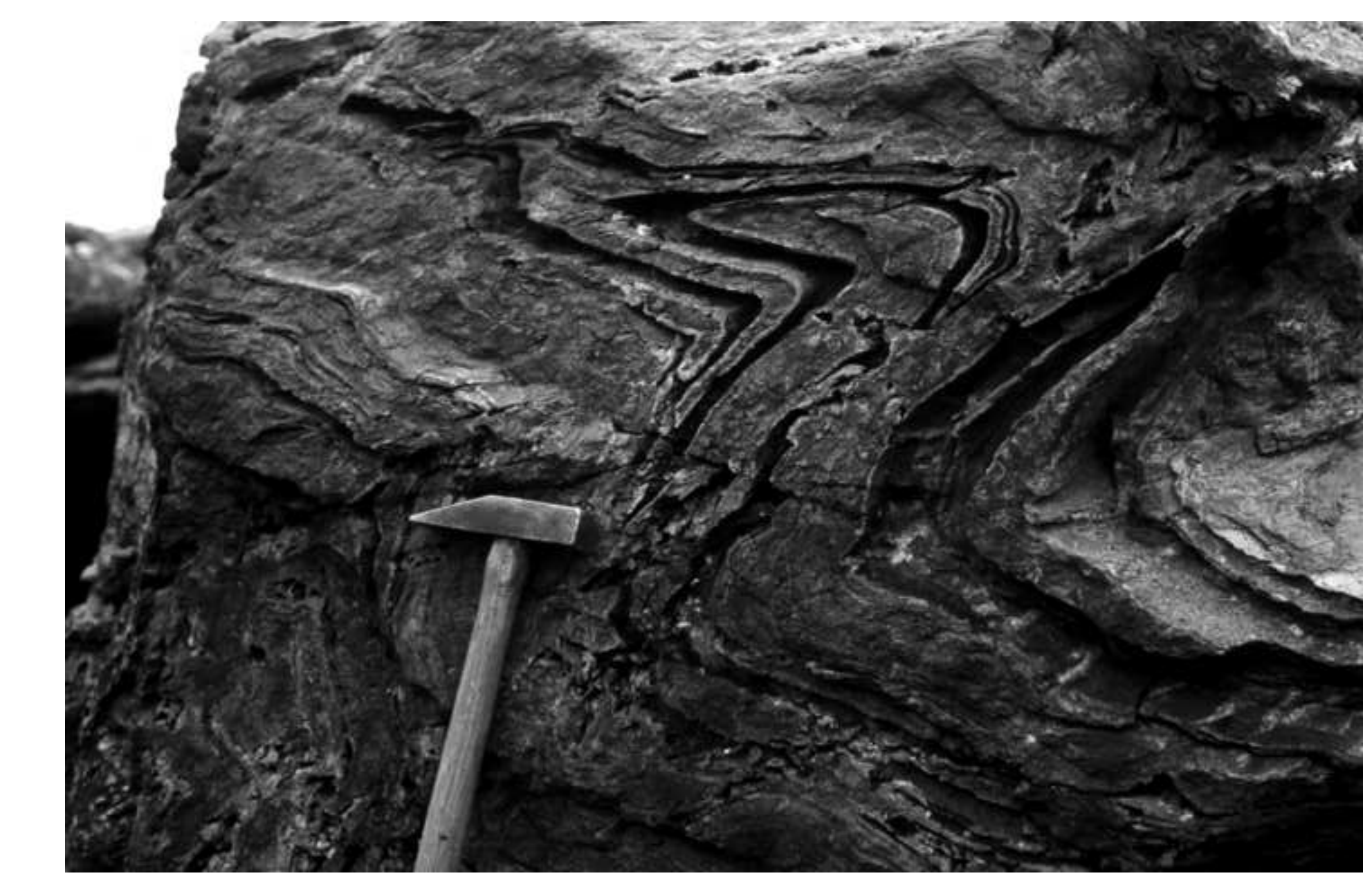




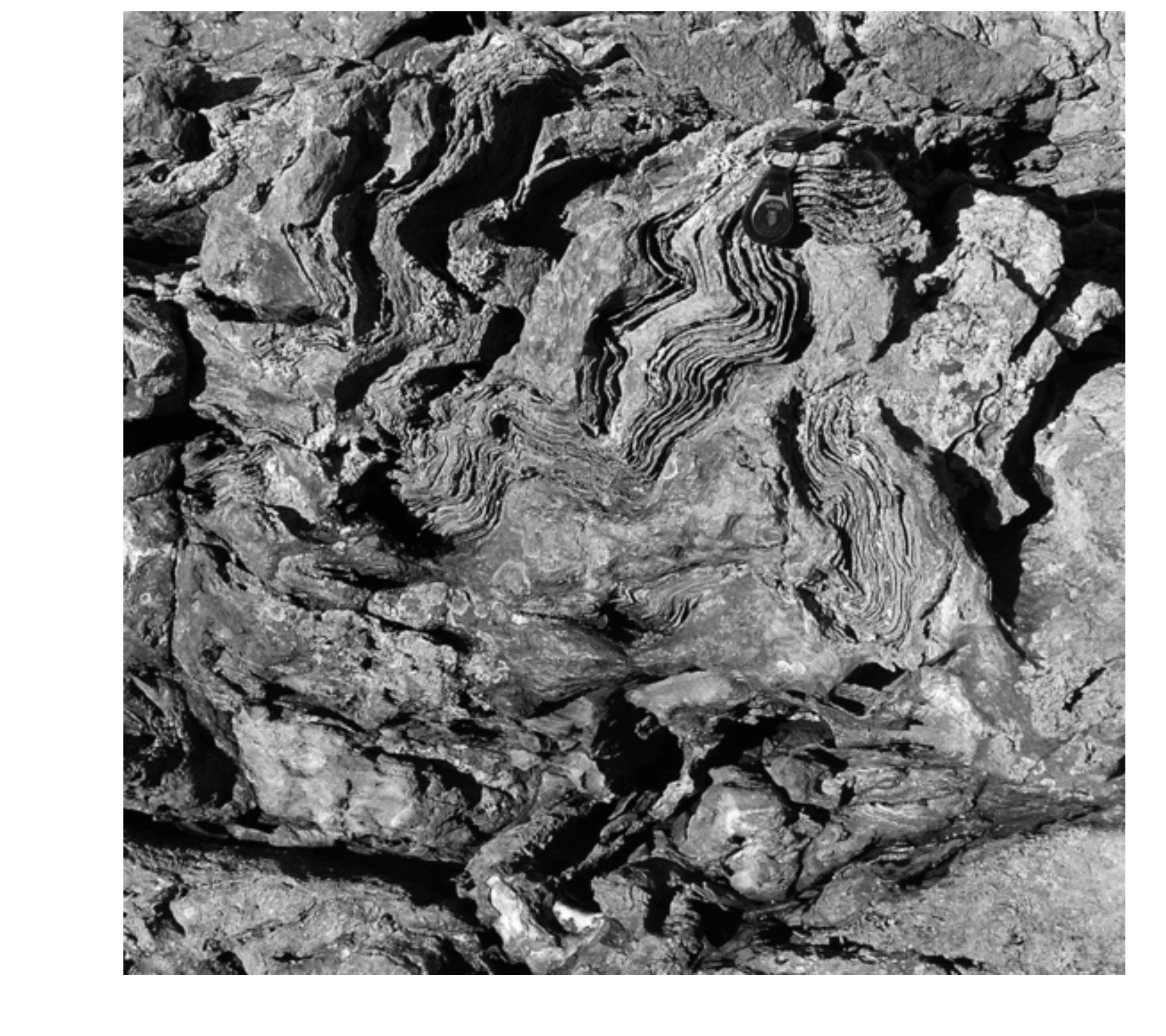

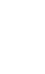

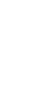 .

.




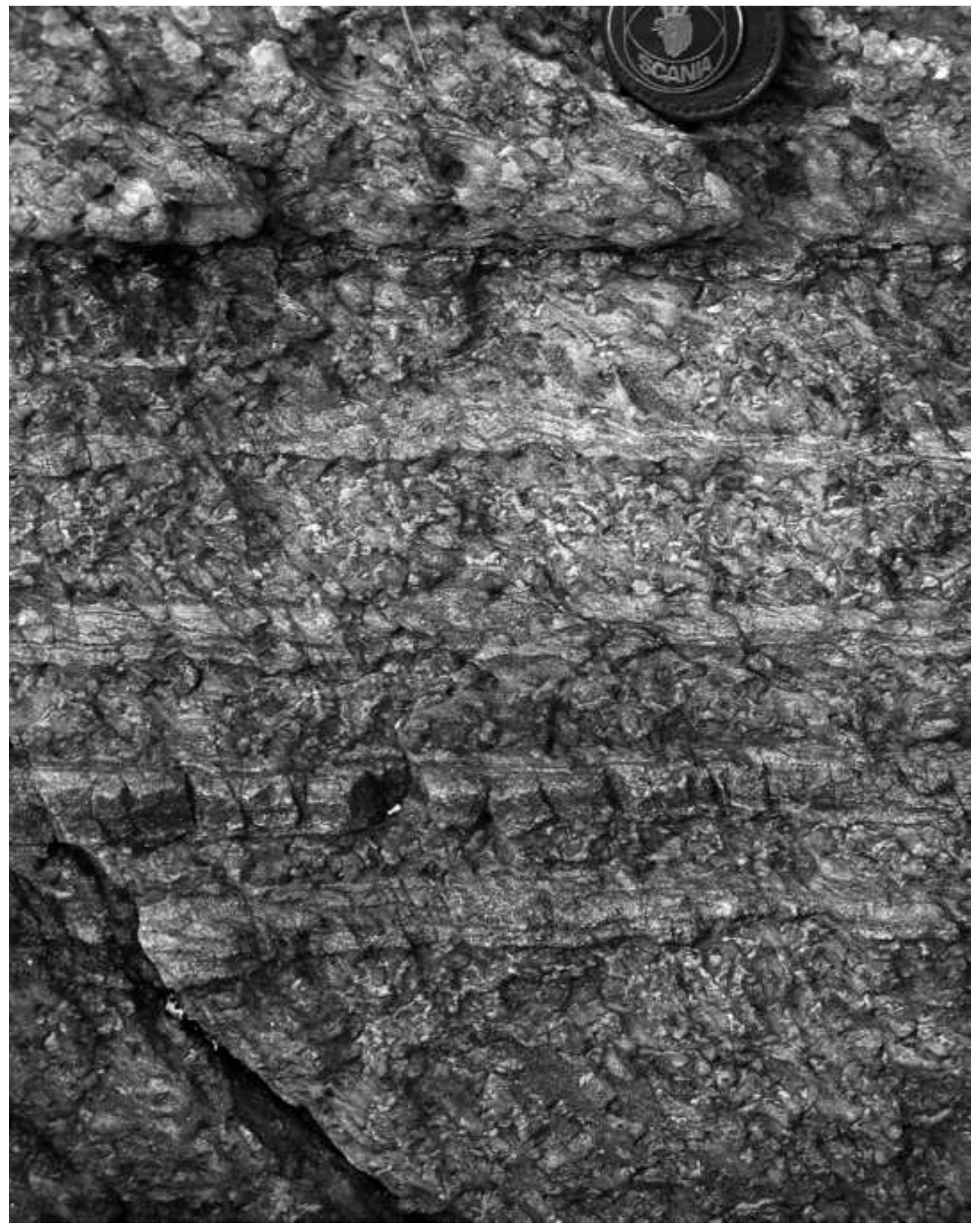




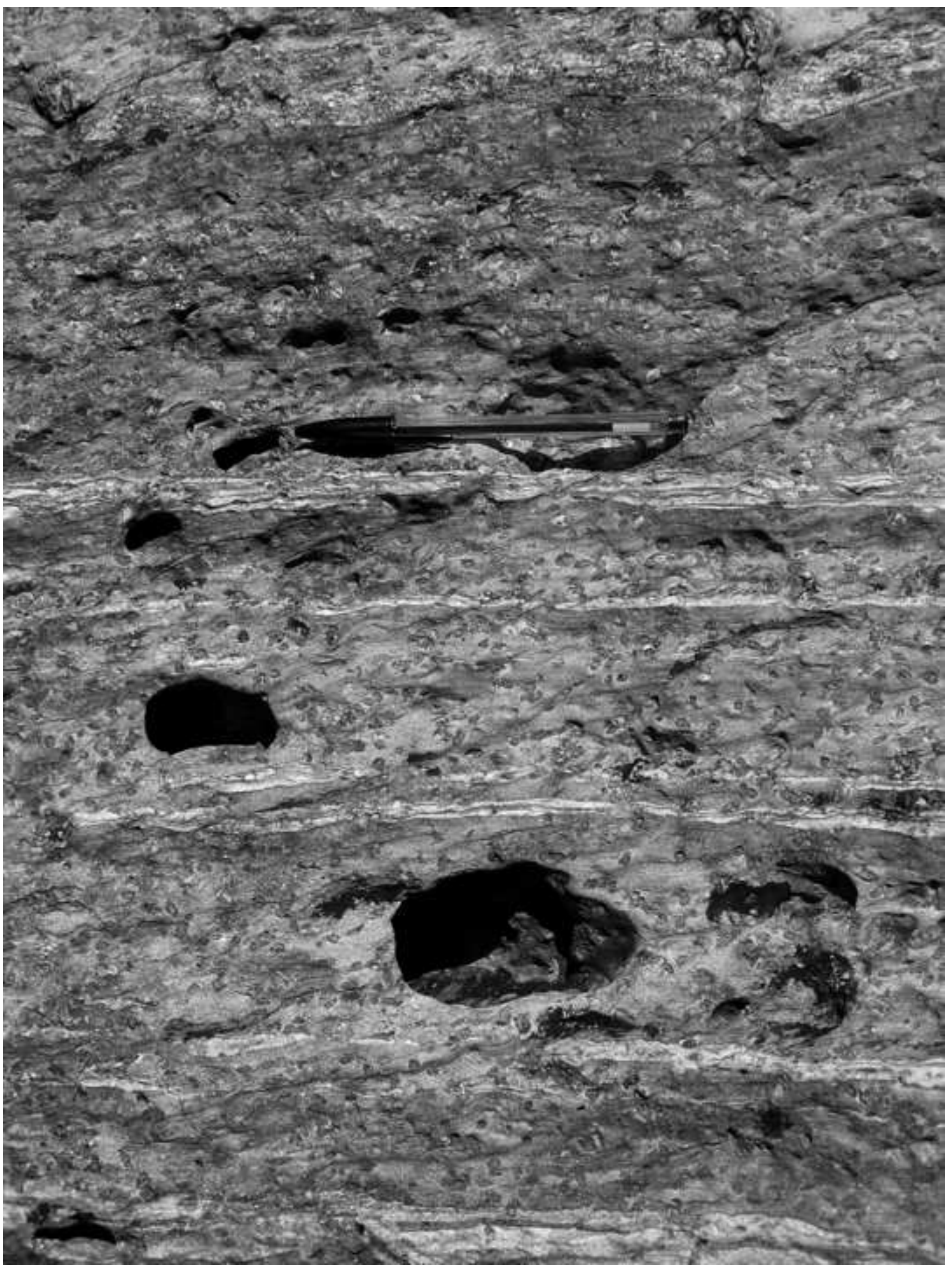

Figure $6.34 \mathrm{~B} \& W$

Click here to download high resolution image
(3) a

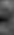
.

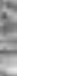

.

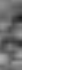

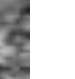

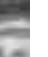

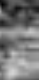

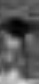

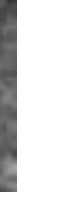




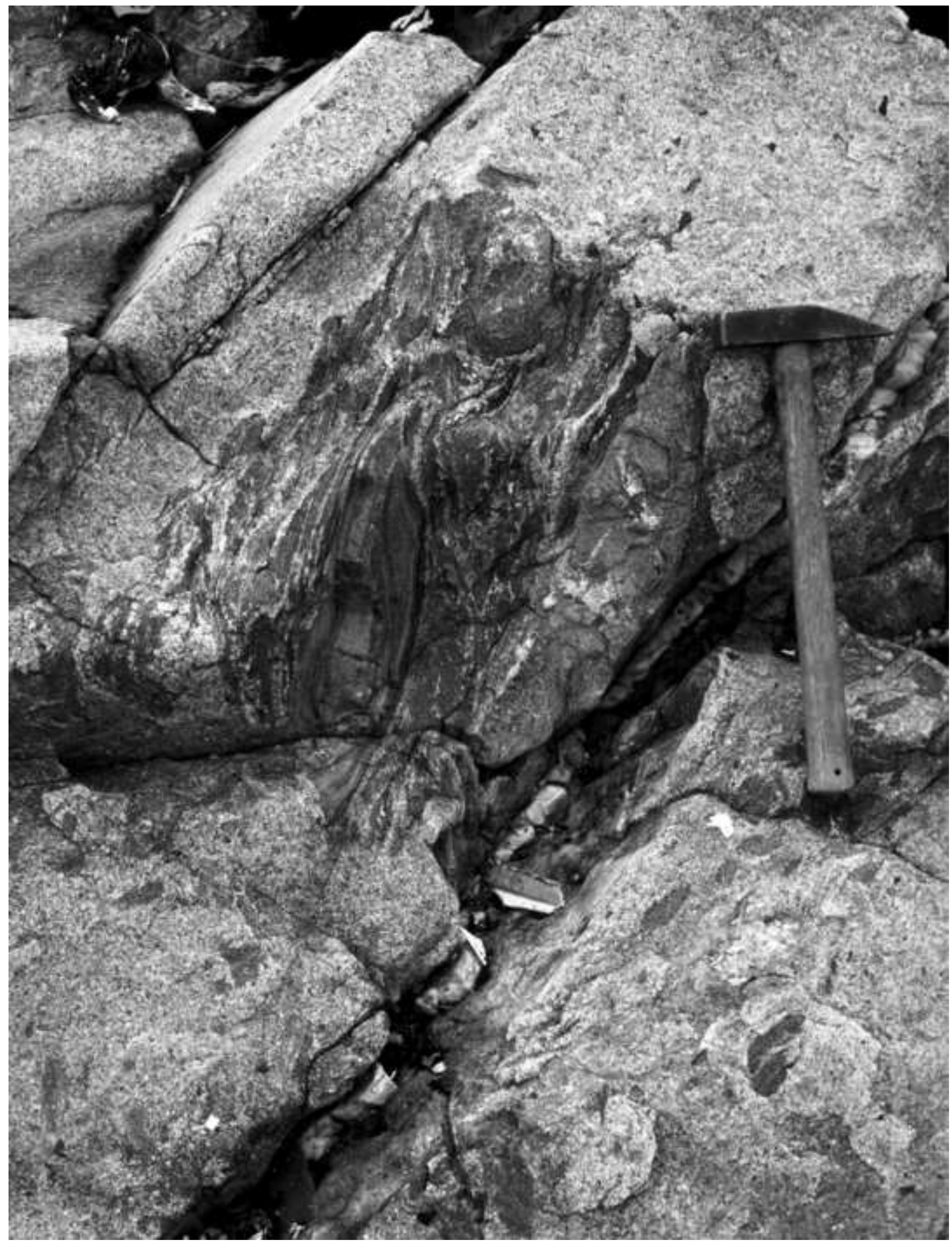




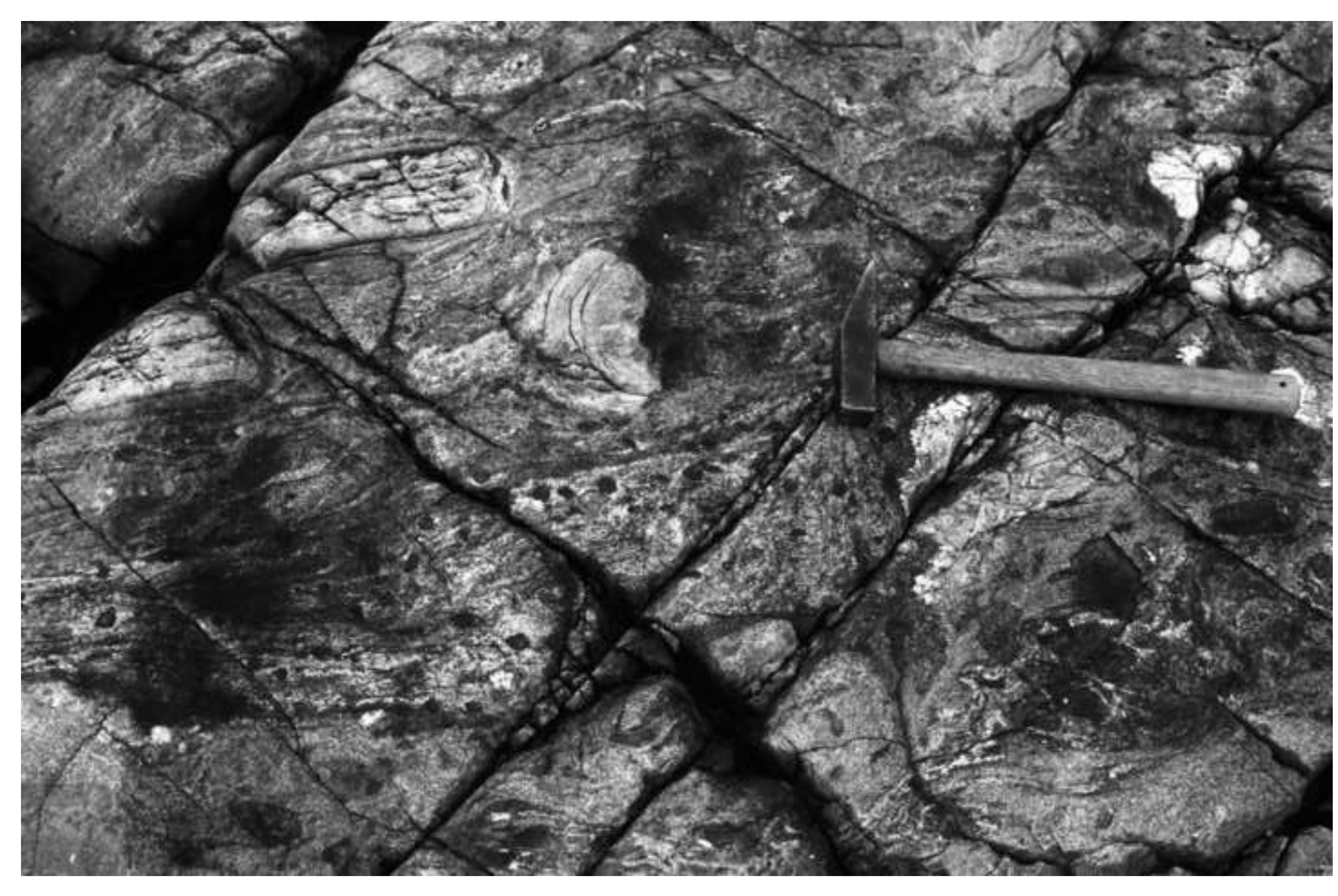


Click here to download high resolution image

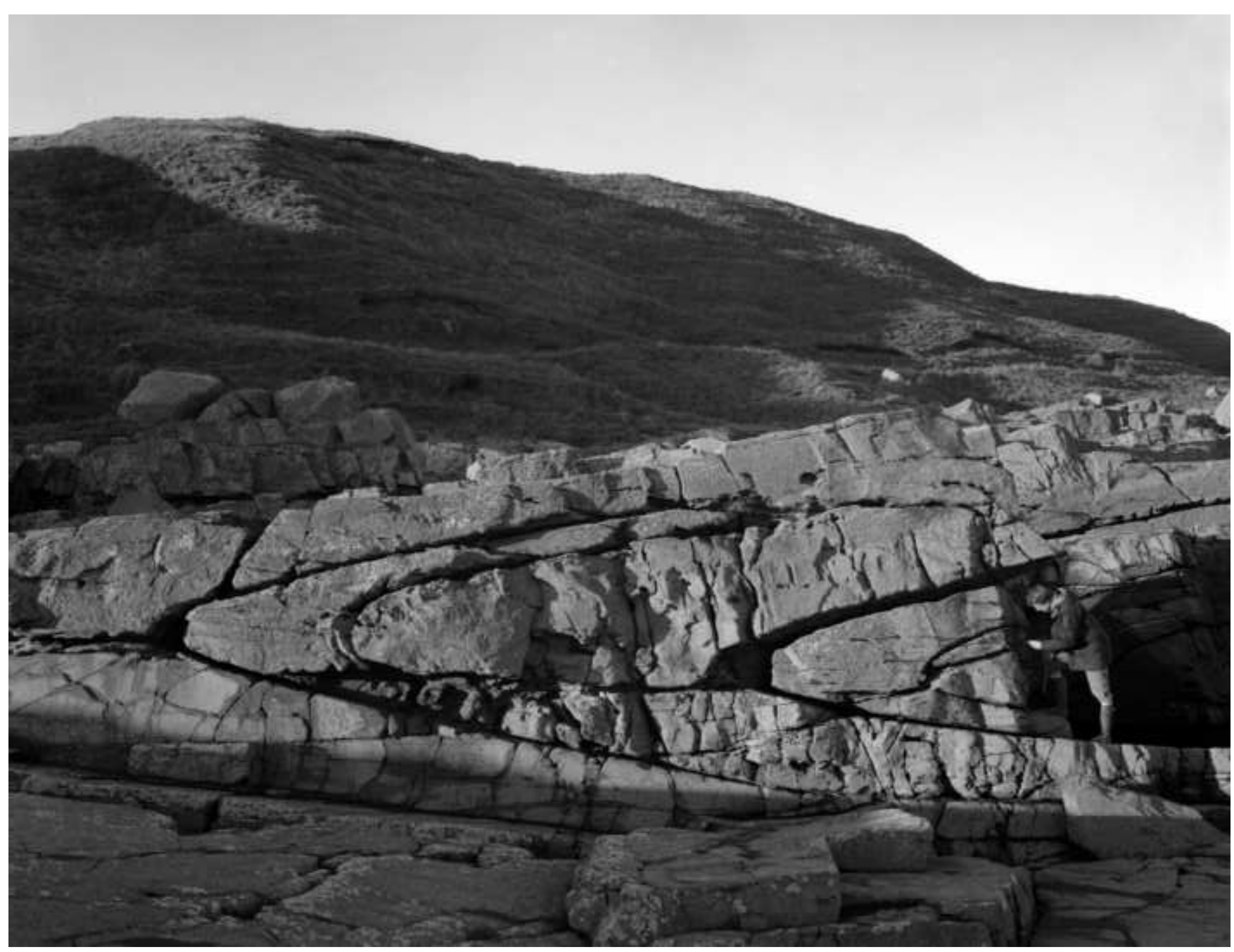

